



THE AFTERMATH OF THE CIVIL WAR, IN ARKANSAS 


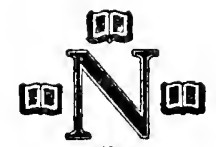

[므 


$$
\theta
$$




\title{
THE AFTERMATH OF THE CIVIL WAR, IN ARKANSAS
}

BY

\author{
POWELL CLAYTON
}

Governor of Arkansas, 1868 to 1871

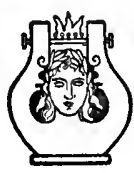

NEW YORK

THE NEALE PUBLISHING COMPANY 
Copyright, 1915, BY POWELL CLAYTON

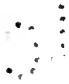




\section{TO MY DEAR FRIEND}

\section{Zhithard $\mathbb{C}$. Zkerens}

IN TESTIMONY OF OUR FIRM FRIENDSHIP WHICH HAS REMAINED UNBROKEN FOR FORTY YEARS 



\section{TABLE OF CONTENTS}

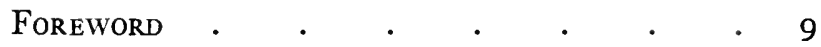

I. Inauguration of the State Government of I 868

II. The Murphy Government . $\cdot$. $~ I 7$

III. My First Message to the General Assembly, Delivered July 3,1868 • $\quad$ • $\quad . \quad 38$

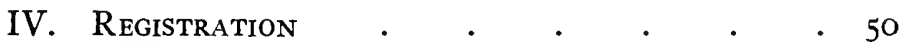

V. Organization and Operations of Ku Klux Klan in Arkansas . $\quad . \quad$. $\quad .56$

VI. Martial Law and Operations Thereunder of State Militia . . . . . . 106

VII. Martial Law in the Counties of Crittenden and Conway Not Permanently Effective 175

VIII. Peace and Prosperity Produced by Martial

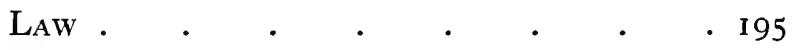

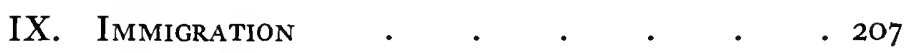

X. Education . . . . . . . . 220

XI. State Aid to Railroads . . . . 237

XII. Funding the State Debt . . . . 251 
8 CONTENTS

CHAPTER PAGE

XIII. William M. Fishback, or Democratic PerVERSIONS OF HISTORY • • . . . . 282

XIV. My October Speech . . . . . 312 XV. The Impeachment . . . . . 319

XVI. My Senatorial Investigation $\quad$ • $\quad$ • 329

XVII. Democratic Accession to Power and the

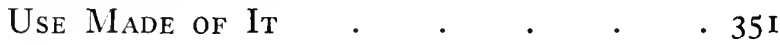
INDEX $\quad . \quad . \quad . \quad . \quad . \quad . \quad .37$ I 


\section{FOREWORD}

For over thirty years I have contemplated writing a history of Reconstruction in Arkansas. Having relinquished all political and business activities, I have, in my eighty-second year, completed this volume of memoirs.

My work gives an account of my administration as Governor; also of those events that commenced before and entered into it, and those that occurred during that period and continued beyond it. It closes with a brief comparison between my administration and that of the opposition, which followed.

I am not regardless of the fact that I have outlived the most of those to whom I have referred in these memoirs and that the criticism may be made that I have waited until their death to make charges that they can no longer answer. I beg that the reader will keep constantly in mind that I am writing of the official acts of my contemporaries and not of their personal characters.

In view of my well-known Republican proclivities, extending over a period of forty-seven years, I have been fully aware of the necessity of substantiating every controvertible and important assertion. In preparing this work for the public I have gathered an immense amount of documentary evidence, from which I have selected the most appropriate for that purpose, and have embodied it either in whole or in part, or have cited the reader to where it can be found. Unless otherwise stated, all doc- 
uments quoted or referred to are on file in the Library of Congress, Washington, D. C.

Throughout this history I have quoted freely from the "Arkansas Gazette," the organ of the Democratic Party. The reader must not confound the "Arkansas Gazette" of today with the "Gazette" of the period covered by this work. Then it was private property and one of its proprietors was an active member of the Ku Klux Klan at Little Rock, Ark. The "Arkansas Gazette" was then the owner of the Associated Press franchise for Arkansas and through that agency it scattered at home and abroad its false representations. Now it is owned by a corporation and is entirely different except as to name, and in my judgment it is at present one of the best newspapers west of the Mississippi River.

The reader will naturally ask why I should have had recourse to such an agency for information. The following are my reasons : first, the accessibility of its files in the Congressional Library, which cover the paper's entire publication from its establishment in I8 I9, at Arkansas Post, down to the present time. Second, it enabled me to fix the chronology of events. Third, as a reflex of the political conditions, animosities, and prejudices then existing. Fourth, to show the "Gazette's" duplicity in denying the existence of the Ku Klux organization, and its constant attempts to shift the burden of Ku Klux atrocities to the shoulders of the Republican Party.

Strange as it may seem, I shall frequently use it as my witness to the good effects resulting from some of my most important policies-policies which it had previously denounced as ruinous.

To Miss Flossie V. Alexander, my Secretary, I wish here to offer my heartfelt thanks for her assistance in the preparation of this book. With untiring zeal and with rare intelligence she has helped me in every possible way. 
No terms of appreciation that I could employ would be too strong in which to express my obligation to her.

I desire here to express to my many friends in Arkansas and elsewhere my appreciation of their unfailing kindness in assisting me to obtain information for use in my book. I have found them ever ready to aid me, and I sincerely regret that I cannot mention them by name.

Washington, D. C.

P. C. August, 19r4. 



\section{THE AFTERMATH OF THE CIVIL WAR, IN ARKANSAS}

\section{CHAPTER I}

INAUGURATION OF THE STATE GOVERNMENT OF I 868

On the second day of July, I 868, in the Old State House grounds at Little Rock, Ark., was gathered a large but incongruous assembly. The seats especially provided in front of the Speaker's stand were occupied by ladies, who, with their multi-colored dresses and vibrant fans, gave dignity and animation to the scene. There was also present a large representation of the Unconditional Union men who had furnished to the Federal Army in Arkansas over ten thousand soldiers.

The newcomers,-composed almost entirely of exUnion officers and soldiers who had been impressed during their period of service with the genial climate and great natural resources of Arkansas and who when mustered out of the service had consequently adopted that State as their home,- - were well and actively represented.

Standing in groups under the shade of the old oaks were gathered members of the ante-bellum régime,men whose contemptuous facial expressions indicated that they were present not as participants in the ceremonies about to take place, but for the purpose of noting them, probably with a view to reporting and discussing them that night in their secret conclaves. 
On the outskirts of the crowd stood, in respectful silence, a large number of the lately enfranchised negroes, who fairly pinched themselves to make sure that they were not dreaming, so great and sudden had been the change from slavery to American citizenship.

About Io A. M. along the Main street leading to the Capitol an open carriage with a military escort approached. The back seat was occupied by two men,the one on the right being about sixty-five years old; the other, about thirty-five. The elder, clad in the homespun garb of the mountaineer, noted the more fashionable attire of the younger man and said: "Why do you wear gloves in July? Only dudes wear gloves in summertime." The younger man took no offense, but quickly replied: "Governor, it is not the garb that makes the man, yet in deference to your opinion, and especially in view of the character of the work $\mathrm{I}$ am about to enter upon to-day, which will doubtless require 'handling without gloves,' I now remove mine." Both men cordially grasped hands, the elder remarking: "I appreciate the magnitude of the work you are about to undertake. May God help you!"

The carriage soon arrived at the gates of the State House grounds, where it was met by a deputation of citizens, who escorted the occupants to the platform where the Inaugural Ceremonies were to take place.

The elder of these two men was Isaac Murphy, then the Provisional Governor of Arkansas; the younger was the writer of this History, and the occasion, his inauguration as the first Governor of Arkansas under the Reconstruction Measures of Congress.

The form of the official ceremonies that followed was, on a small scale, similar to the one that is generally used in Presidential inaugurations. I omit here my inaugural address, its main features being embodied in 
my message to the Legislature, which was delivered the next day.

Upon the termination of the inaugural ceremonies, and at the suggestion of ex-Governor Murphy, we repaired to the State House, where we first visited the executive chambers. Upon entering the executive office I saw before me, placed against the opposite wall, a long table with three convenient drawers and on the table a case of open pigeonholes. There was no carpet on the floor, and the rest of the furniture consisted of about two dozen homemade, split-bottomed chairs. On the other side of the room, over the fireplace, was a print of George Washington,-the only picture on the walls. From this room we entered a small anteroom, which contained no furniture nor other movable objects, except a barrel standing on end in the middle of the room. This barrel was apparently filled with straw. From it ex-Governor Murphy fished out a gallon stone jug, removed the cork, and politely presented the jug to me. After proposing his good health and future prosperity "at the word of mouth," I partook of its contents. It was the real "mountain-dew," as the Governor had characterized it. He now closed his hospitalities by a similar potation and with words kindly expressive of his good wishes. We then made the rounds of the building, visiting such provisional officers as had not yet vacated their posts.

On our way Governor Murphy pointed out to me the exact spot where had occurred a tragedy that was perhaps unexampled in its horrible details in the whole history of legislative proceedings in America.

In the year I 837 the House was in session, with John Wilson, Speaker, in the Chair. J. J. Anthony, the member from Randolph County, had the floor and was addressing the House. The proposition under consideration was that upon the delivery of wolves' scalps to 
Justices of the Peace certificates indorsed by them should be receivable in payment of county taxes. Anthony sarcastically suggested that such certificates should be countersigned by the President of the Real Estate Bank, who was the same John Wilson then occupying the Chair. To these remarks the Speaker took offense and ordered Anthony to take his seat, which Anthony refused to do; whereupon the Speaker, without invoking the authority of the Sergeant-at-Arms, left the Chair, saying, "Then I will make you." As he descended from the Speaker's stand he drew his bowie-knife and advanced down the aisle to where Anthony was standing behind his desk. Anthony drew his knife and a struggle ensued. Grandison D. Royston, who occupied a seat adjacent to Anthony's, thrust a chair between the combatants. In the scuffle Anthony dropped his knife, whereupon Wilson with his left hand raised the chair, and stooping down to make his aim sure, thrust his bowie-knife into the vitals of Anthony, who exclaimed as he fell, "I am a dead man." $\mathrm{He}$ instantly expired in a pool of his own blood. Wilson was promptly indicted by the Grand Jury for murder in the first degree, but upon a change of venue to Saline County, at that time sparsely settled by a very ignorant class of people, he was acquitted on the ground of excusable homicide.

I cannot close this chapter without paying a just tribute to Governor Isaac Murphy. He was a diamond in the rough, but the very personification of honesty and loyalty to his country. May his name live in History as long as the annals of Arkansas exist.

I shall simply add that on the day of my inauguration, on my taking the oath of office, the "Ship of State" was launched on what afterwards proved to be a most tempestuous sea. 


\section{CHAPTER II}

\section{THE MURPHY GOVERNMENT}

At the very outset of my administration I was confronted with the contentions of the Democratic Party. It claimed that the government created under the Reconstruction Acts of Congress, according to the views expressed by the Democratic National Convention, was "unconstitutional, revolutionary and void," and that the Legislature which the Reconstruction Measures under the existing conditions had characterized as "provisional" was "in no sense provisional, but the Legislature of the State of Arkansas, created and elected according to the forms of law and the Constitution."

That the reader may understand the basis of these insurrectionary and anarchistic contentions, I shall now give a history of the closing period of the war in Arkansas and the origin and attempted usurpations of what was known as the Murphy Government. During its formative processes it was characterized by the Secessionists as "bastard and bogus." The Confederates in the field were given orders to suppress it and its meetings as far as possible; but later, when by the devious devices hereafter described, it came under the control of the Secessionists, or Democrats, they assumed for it all the powers of an equal and coördinate State of the American Union.

I 863 was a prosperous year for the Federal cause in Arkansas. Its successes at Arkansas Post, Helena, Little Rock and Pine Bluff were complete. The reverses were few and of small importance. 
From these favorable conditions resulted the following Federal military dispositions: the Arkansas River became the military base, with the main body of the army and its headquarters at Little Rock, the Capital and the geographical centre of the State,-a strategic position of great military importance. This base was strengthened by auxiliary posts at Ft. Smith, Van Buren, Dardanelle, Lewisburg and Pine Bluff; and in the rear, to protect its communications and the territory recovered from the Confederacy, posts were established at De Valls Bluff, Helena, Batesville, and Fayetteville.

These dispositions practically dominated the rich valley of the Arkansas and all of the State Territory to the southward. The hitherto hounded and harassed Union men of the State, with new hope and courage, now came from their hiding places and flocked by thousands to the Federal posts, where, to a great extent, they entered the Federal volunteer service.

Desertions from the Confederate army by Union men forced into the Confederate service by conscription now became frequent. To a large extent they too enlisted in the Union army.

Adjt.-Gen. A. W. Bishop in his report of 1863 , printed by authority of the United States Senate, fixed the whole number of white officers and enlisted men belonging exclusively to Arkansas organizations at 8,789 . If we add to these figures the number of Arkansas men who joined Northern regiments serving in Missouri and Arkansas, the whole number would certainly exceed I o, 000.

Under these conditions, on the $24^{\text {th }}$ of October, I 863 , twelve self-constituted Union men, from the contiguous counties of Sebastian and Crawford, met in conference at Ft. Smith and issued a call to the Union men of their counties advising them to assemble in mass meet- 
ings at their respective County seats (Ft. Smith and Van Buren) for the purpose of inaugurating a movement for the formation of a loyal State government in Arkansas. Meetings were held and resolutions adopted, calling upon the loyal people of the several counties of the State to hold conventions and select delegates to a State constitutional convention, to assemble in Little Rock, January 4, I864. Information, especially documentary, as to the extent and manner of response to this call is meagre.

All of the Federal military posts were located at County seats, places of refuge for the Unionists and of safety for the holding of such meetings. Unless the meetings at Ft. Smith and Van Buren to which I have referred selected delegates, I know of but one other that did. In William M. Fishback's newspaper, The Unconditional Union, of January 23, I864, is an account of a meeting held January 2 in the Episcopal Church at Helena, presided over by Federal Brigadier-General Buford, at which delegates for Phillips County were chosen.

From the able article by Prof. John Hughes Reynolds, styled "Presidential Reconstruction in Arkansas," Vol. I, Publications of the Arkansas Historical Association, I quote as follows: "If conventions were held, many of them could not have been more than quiet, informal, irregular gatherings of loyal men in the several counties. ... In some cases the delegates were selfappointed; others were selected by home caucuses; and in a few cases citizens of different counties, residing in Little Rock for protection, got together and selected one or more of their number." 1 While the title of this article is misleading, there being no such thing as "Presidential Reconstruction," the quotation I have used correctly describes the methods pursued in the selection of delegates. 
In this irregular manner a comparatively small number of delegates was chosen,-a few of whom assembled at Little Rock on the 4th day of January, I 864 , the day fixed for the meeting of the Convention, and effected a temporary organization.

I now present a brief account of the subsequent proceedings of the Convention, as gleaned from its journal. ${ }^{2}$

January 6 a Committee on Credentials was appointed.

January 8 the Committee on Credentials reported twenty-six delegates, from eleven counties, entitled to seats.

January 9, on report of the Committee on Credentials, four delegates from Pulaski County were seated. Why the delegates from the county where the Convention was held did not participate in the first day's proceedings, and, in the absence of any contest, did not take their seats until five days thereafter, I can only account for upon the theory that they were chosen after the Convention assembled.

January I I the Committee on Credentials reported as follows: "We have received applications from individuals from counties unrepresented, and in which no elections were held, desiring to be reported as members of this Convention. The Committee have considered these applications for several days and have finally decided to report no persons as entitled to seats without certificates of election emanating from the authority of the people."

Two days thereafter the same Committee recommended the seating of three citizens of Jefferson County, in support of which the Committee said: "After due deliberation, we agree to recede from so much of our former practice as required the delegates to furnish a certificate of election and we further agree to admit them (the three citizens) to seats with us." Altogether there 
were eleven delegates so seated, one of whom, William Cox of Drew County, is recorded as having voted for the adoption of the Constitution on January I9, whereas he was not admitted to a seat in the Convention until two days thereafter.

During the first nine daily sessions, in addition to the proceedings already mentioned, committees on rules and for the drafting of a constitution and ordinances were appointed and a permanent organization effected. Rules were adopted and other important business transacted without any roll-call. Hence I am unable to state the number of delegates who participated in these proceedings.

The largest number of delegates present at any session was forty-five. The largest number of counties represented in whole or in part was twenty-three. The entire number of counties in the State was fifty-five.

Geographically, the State of Arkansas consists of two nearly equal and compact sub-divisions,-Highlands and Lowlands. The Highlands,-exclusive of the Arkansas Valley,-were not adapted to the culture of cotton by slave labor, and to a major extent were inhabited by the non-slaveholding class, who, having no interest in slavery, naturally refused to fight its battles. Hence the strong Union sentiment which existed there.

In the Lowlands at the commencement of the war were located the cotton-producing and slave-holding interests. Possessed of wealth and educational advantages, firmly united by a community of interests, the slaveholding class there effectually controlled the ignorant and, in most cases, wretchedly poor, non-slaveholding people.

The small Union sentiment which may have existed among the non-slaveholding class was largely dispelled by President Lincoln's Emancipation Proclamation, and 
by the enlistment into the Union army of negro soldiers. The fixed policy of the slaveholders was to keep this class in a continuous state of illiteracy, hence the failure of the State to provide free schools, a subject that I shall treat more fully further on.

I return to the consideration of the composition of the Convention. From the Highlands there were twentyfive delegates representing either in whole or in part twelve counties, with an aggregate white population of about 76,000 . In this region there were sixteen counties, with an aggregate white population nearly equal to that of one-third of the entire State, wholly unrepresented.

From the Lowlands there were twenty-four delegates, representing either in whole or in part eleven counties, with an aggregate white population of 68,000 . There were sixteen unrepresented counties in that region with an aggregate white population of about 66,000. The white population of the Highlands exceeded that of the Lowlands by about 40,000.

The Highland county of Washington, the most populous in the State (and with the largest Union sentiment), with Fayetteville, its county seat, garrisoned by Arkansas Federal troops, had no delegates in the Convention. On the other hand, the Lowland county of Clark had four delegates, though it had only about half the population of Washington county and a very insignificant Union sentiment, and its county seat of Arkadelphia (according to Professor Reynolds "the manufacturing centre of the Confederacy") was garrisoned by Confederate troops.

The Highland county of Independence, the next most populous county in the State, containing an unusually large Union sentiment, with a garrison of Federal troops at Batesville, its county seat, had but one delegate, who 
was admitted without credentials, and who served only five days; while the Lowland county of Saline, with less than one-half of the population of Independence, and a very small Union sentiment, had four delegates. These two contiguous Lowland counties, Clark and Saline, had altogether during the sittings of the Convention, as shown by its journal, eight delegates, - about one-sixth of the entire body, or one delegate for every 1,676 white inhabitants. Upon this basis Washington and Independence counties together would have been entitled to sixteen delegates and the whole State to about one hundred and ninety.

The journal shows that of the twenty-four delegates from the Lowlands ten were admitted without credentials, while a number of others were seated from counties within the Confederate lines, where public meetings for the selection of delegates could not possibly have been held.

From the foregoing two pertinent questions arise: first, Why, considering the easy and secure methods of selecting delegates from the Highlands region, had it such a small representation in the Convention? second, Why, in view of the difficulties and dangers attending the selection of delegates from the Lowlands, the comparatively small Union sentiment existing there and the fact that its population was about 40,000 less than that of the Highlands, were there such comparatively excessive delegations from that region?

Having continuously served in Arkansas, as a commander of Federal troops, during the last three years of the war, and having had favorable opportunities for observing this movement throughout its different stages, I know that the consensus of opinion at that time in army circles was that, with the exception of a few promoters whose eyes were doubtless turned to the vacant 
Federal and State offices, the Union men of Arkansas took but little interest in the movement.

A State constitutional convention under our system, as I understand it, is a parliamentary body of delegates, previously called, and its delegates apportioned by lawful authority among the several counties, or other legal sub-divisions of a State, its delegates having first been chosen by lawfully qualified electors at elections provided for by law, conducted and returns made by election officers duly and legally qualified.

If this definition be correct, then the body we are considering did not possess a single one of these qualifications. I know that it was asserted at one period with vehement insistence that President Lincoln legalized this movement. He did support the creation of a Provisional government, subservient and auxiliary to the then existing military authority, but never a government of a sovereign and coördinate State of the Union. The fact is that contemporaneously with this movement-at least up to the time of the assembling of the Convention-he was devising a plan for the formation of a provisional government for Arkansas, unaware of the movement then in progress there.

In a letter to Major-General Steele, dated Jan. 5, I 864, he wrote: ${ }^{3}$ "I wish to afford the people of Arkansas an opportunity of taking the oath prescribed in the proclamation of December 8, I863, preparatory to reorganizing a State government there." When this letter was written the Arkansas Convention was in session.

On January 27 he wrote to Major-General Steele: "I have addressed a letter to you and put it in the hands of Mr. Gantt and other Arkansas gentlemen, containing a program of an election in that State. This letter will be handed you by some of these gentlemen. Since writing it, I see that a Convention in Arkansas, having 
the same general object, has taken some action, which I am afraid may clash somewhat with my program. I therefore can do no better than ask you to see $\mathrm{Mr}$. Gantt immediately on his return and with him do what you and he may deem necessary to harmonize the two plans into one, and then put it through with all possible vigor."

February 6 he telegraphed Governor Murphy: "My order to Major-General Steele about an election was made in ignorance of the action your Convention had taken or would take. A subsequent letter directs General Steele to aid you in your plans and not to thwart or hinder you. Show this to him."

On February $\mathrm{I}_{5}$, in a telegram to Gen. J. M. Thayer, he used this language:4 "I, having acted in ignorance that the Convention would act, yield to the Convention, and have so notified General Steele, who is master, and is to cut any knots which cannot be untied."

On February I 7 he wrote to William M. Fishback: "I have sent two letters to General Steele, and three or four dispatches to you and others, saying that he, General Steele, must be master, but that it will probably be best for him to merely help the Convention on its own plan. Some single mind must be master, else there will be no agreement in anything, and General Steele, commanding the military and being on the ground, is the best man to be that master. Even now the citizens are telegraphing me to postpone the election to a later day than either that fixed by the Convention or by me. This discord must be silenced."

On January 29 he wrote to Major-General Steele: "I understand that Congress declines to admit to seats the persons sent as senators and representatives from Arkansas. These persons apprehend that, in consequence, you may not support the new State government 
there as you otherwise would. My wish is that you give that Government and the people there the same support that you would if the members had been admitted, because, in no event nor in any view of the case, can this do any harm, while it may be the best you can do toward suppressing the rebellion."

I regret the limited scope of my work does not permit a reproduction of all President Lincoln's orders to General Steele and his letters to others relative to the formation of the Murphy government. The foregoing quotations contain his most pertinent expressions concerning the questions we are considering, and, I think, clearly show that all he did in the premises was in his military capacity as Commander-in-Chief of the national forces.

Certainly the formation of a government of a sovereign and coördinate State of the Union, from its inception to completion, is the work of civil authority. In that work the military can take no independent part. In it the military exercise of "mastership," with "power to cut knots which cannot be untied," would certainly be a gross usurpation, but not so under the then existing conditions in the formation of a provisional government, subservient and auxiliary to the military, to aid in the "suppression of the rebellion."

In this connection I present some extracts from the speech of Senator Charles Sumner, delivered in the United States Senate on June I3, r 864, "On the Recognition of Arkansas." Among other things he said: "The present organization in Arkansas, seeking representation on this floor, is without that legality of origin required by the American system of Government." "A new Civil Government, to be recognized as a State of this Union, cannot be born of military power."

Continuing, he said: "True it is that the President put forward a plan for reorganizing a loyal State Gor- 
ernment in the Rebel territory, and he proffered a guarantee to these communities against domestic violence and rebel invasion, but he neither proposed nor promised any representation in Congress or in the Electoral College." In the further course of his remarks he said: "It is plain, therefore, that the reorganization contemplated by the President was in its nature provisional."

And again he said: "A handful of persons keeping their loyalty might justly look to the military power for support against a hostile majority. Such a handful might be allowed to set up a local Government for the management of local affairs, and to assist the National Government in the work of restoration."

Further on he said: "Besides, the power of the President to institute this Government is only as Commander-in-Chief of the Army. It is therefore military in character. But what proceeds out of this is, from the nature of the case, provisional or temporary until it has received the sanction of Congress."

Early in the war the President, in his military capacity, had appointed a military governor for Arkansas and conferred upon him civil duties. Later he abrogated that action, and as late as February 5, I864, announced to an Arkansas (loyal) delegation, "that he had determined not to appoint a separate Military Governor, but to entrust General Steele, the newly appointed commander of the Department of Arkansas, with both military and civil adminstration of the State."

Having described the origin, composition and character of the Convention, we now come to its work.

Misconceiving its powers, it adopted ordinances as follows: Prohibiting the bringing into the State of free or indentured negroes, annulling all laws that prohibited the education of any class, making it a felony to belong to a company of guerillas, jayhawkers, or bushwhackers; 
authorizing a loan of $\$ \mathrm{I} 50,000$, and providing for the organization, by the Governor, of state militia.

On January 20 it ordained a provisional State government, consisting of the Governor, Lieutenant-Governor, and Secretary of State, and at the same session these offices were filled by the appointment of Isaac Murphy, C. C. Bliss, and Robert J. T. White.

On January 22 the Convention adopted by an unanimous vote the State constitution previously in force, with the following most important amendments: the annulment of the act of secession, the immediate abolition of slavery, and the complete repudiation of the Confederate debt.

It adopted a schedule providing for an election to be held March I4, I5, and I6, for the adoption or rejection of the constitution and for the election of State and county officers, a State Legislature and "members of Congress in Districts No. I and 2, according to the act approved January 19, r86r." No election was ordered for District No. 3. The Convention recognized the election of Col. James M. Johnson as the representative from that district.

Notwithstanding the failure of the mass meeting method of selecting delegates, the Convention for the forthcoming election based its machinery on the same invalid and impracticable plan.

At the risk of wearying my reader at the outset, I have, with perhaps too much particularity, described the formative processes which led to the installation of the so-called Murphy Government, but I believe it expedient that a complete history be given, as I shall soon describe the fierce and often bloody contentions over the question of the legitimacy of said Government and the power of Congress to provide for its displacement by that of another. 
Of its war-time history there is but little of interest to record. Upon its installation it relieved General Steele of the civil functions he had up to that time performed and thus enabled him to concentrate his strictly military efforts toward the "suppression of the rebellion."

Its legislature undertook to fill the two vacant seats in the United States Senate by the election of Elisha Baxter and William M. Fishback, both of whom, it is scarcely necessary to say, were refused admittance by that body. At last the long-drawn-out hostilities between the loyal and disloyal States came to an end, and with it the complete dissolution of the governments of the States that had constituted the Confederacy.

The governing powers at Washington were now confronted by the alternatives of the continuance, for the time being, of the Murphy government, or its dissolution and the return of the powers conferred upon it by the military authority to the source from whence they had sprung. It seems to have been the policy of the General Government to give this provisional government a full and fair opportunity to demonstrate its loyalty and good faith.

I shall now pass rapidly on toward the period of actual reconstruction in Arkansas, which commenced with the enactment of the Congressional Reconstruction Measures.

THE CAPTURE OF THE MURPHY GOVERNMENT BY DEMOCRATS

One June day in I 866 my old friend, Col. Willoughby Williams, and I were by accident fellow-passengers on a Mississippi River steamboat,- - he on his way to his summer home in Nashville, Tenn., and I on a business trip to Memphis. The Colonel was a citizen of Ten- 
nessee, but nearly all his business and family interests were in Arkansas, where he passed the greater part of his time. His politics were strictly of the ante-bellum Democratic school.

The day being sultry, we sought the shade of an awning on the hurricane deck, and whiled away the time in the discussion of subjects of mutual concern, as we were both planters on a large scale and, under the new conditions produced by the emancipation of the slaves, "in the same boat." By and by our conversation turned to the Congressional breach between President Johnson and Congress, which as it widened day by day raised correspondingly the hopes and the expectations of the political school to which the Colonel belonged.

I must acknowledge that in this quarrel at first I was inclined to adopt the views of the President. This the Colonel knew. Hence, reinforced by confidence-producing juleps, he then and there unfolded to me the whole scheme for the restoration of the old slave-holding régime in the State, of which the first and most important step was to secure Democratic representation in Congress from Arkansas. With such representation, "the good people," as he termed his political associates, "would then be able to manage their own affairs to suit themselves."

This end was to be attained through three successive stages: first, through the temporary acceptance of the once hated and despised Murphy Government; second, through Democratic success at the biennial election to be held in August of that year; third, pending the acquirement of representation in Congress, the wielding of the powers of the State with such tact and discretion as would tend to quiet the suspicions of the Northern people. This, under their scheme, required the adoption of a "make-believe" policy in the putting 
forward of men for United States Senators and Representatives in Congress who had not been too prominent in the secession movement.

Colonel Williams enlarged upon the advantages of the recognition of the "Murphy Government." It would appeal to the North as an evidence of the acceptance by the ex-Confederates of the situation; while at home Murphy would be but a figurehead whose veto could be overcome, if they were successful. The Colonel expressed the hope that by this plan they "would recover by the ballot what they had lost by the sword." This was his exact language! I have never forgotten it.

I concluded to take no part in their movement but to continue my business activities on my plantation. Hence when a delegation of gentlemen from Pine Bluff waited upon me with a propostion to allow the use of my name as a Democratic candidate for Congress I respectfully declined. Afterwards, when circumstances forced me into the whirlpool of politics and I became Governor of Arkansas, the information imparted to me by Colonel Williams was of the greatest value. It was the lifting of the veil that enabled me to see clearly at all stages the true character of Democratic inwardness.

In due course the biennial election was held, and in accordance with the Colonel's expectations the returns showed that the ex-Confederates had elected, by an overwhelming majority, members of both houses of the Legislature and, with a few unimportant exceptions, all the other elective officers.

This election with its official machinery was based upon the re-enactment by the "Murphy Government" of the ante-bellum constitution. For the Republicans to have accepted this usurpation of power would have been to concede the whole contention. Hence, as a general thing, they remained away from the polls. On the other 
hand, the ballot boxes were thrown wide open, and all the class afterward excluded by the Reconstruction Acts was permitted to vote.

On the 2oth day of December, I 866, the Legislature just referred to sent a commission to Washington, D. C., for the alleged purpose of a conference with the Government of the United States as to the political condition of the country. ${ }^{5}$ The real purpose was to gain over, by deceptive representations as to conditions in Arkansas, a sufficient number of wavering Republican Senators and Representatives to secure the admission to both Houses of Congress of their Senatorial and Congressional representatives. Upon the return of the Commission from Washington, it made a report to the Joint Assembly, ${ }^{6}$ from which I quote as follows:

"We cannot, however, close this report without endeavoring to impress upon our fellow-citizens the importance, the absolute necessity, of remaining quiet, of preserving good order, and a quiet submission to and a rigid enforcement of the law everywhere within the limits of the State.

"Outrages upon freedmen, violations of law that are permitted to pass unpunished, are reported by 'arguseyed' letter writers, whose whole stock in trade consists in this morbid desire to foment sectional strife.

"Upon the importance of remaining quiet, orderly, and patient, under the state of things now surrounding us, we have met the following in one of the newspapers published in the city of Memphis, which embodies the views of the committee so fully and expresses them so clearly that we present it as the conclusion of this report:

"If there ever was a time in the history of the people when they had everything to gain by being perfectly quiet and impassive, under the bluster and threats of a certain class of politicians, that time is at hand in the South. There is no provocation which should induce 
them to lose their self-possession and make imprudent or passionate remarks. They should allow the Butlers, the Stevenses, and the Sumners to do all the bullying. They should listen to the violent harangues of these men with perfect equanimity. They should exhibit no antagonism to these chiefs of crimination against their section. These men feed upon the responses which their malevolence evokes; not to notice them is to destroy them. They have grown skillful in so shaping their assaults as to bring out the greatest amount of resistance from the South. But when the South ceases to resist, their vocation is gone.'

"We wish we could impress this serious truth upon our countrymen. To let them alone is the surest method to break the force of their attacks. Opposition is the life of their policy, and hostility, open and active, builds them up. On the contrary, when they are no longer resisted, they lose all their force and influence. A Memphis or New Orleans riot would vitalize their party and prolong its existence. A few inflammatory articles from our newspapers, or speeches from leading men in our midst, would give them a new lease upon political life. "We must be prudent and cautious if we wish to defeat these practical and cunning antagonists. We must furnish no food for their libels, no pretexts for their assaults; if we do this, they will naturally fall to pieces and divide. There is no cohesion among them but the common desire of remaining in office. This they have obtained by hostility to the South. If we demonstrate by our conduct, our prudence, and our silence that we are pursuing our private interests without detriment to anyone, and that we are determined not to regard the calumnies of our enemies, the great mass of the people of the North will see that these mischief-makers have deceived them, and will change their tone with reference to our people.

"Already we see signs which unmistakably indicate that the radical party is beginning to disintegrate, and 
if the whole people, everywhere in the State, will preserve law and order, they will arm themselves with a power which no adversary can resist."

The enactment of the Reconstruction Measures about three months later precipitated a change from their pretended policy of peace, quiet, and submission to the extreme of insurrection and anarchy that was, alas, too realistic. The part the $\mathrm{Ku}$ Klux Klan played in the execution of this last policy I shall fully describe later on.

The Democratic Provisional Legislature was about to reconvene after the passage of the Reconstruction Acts when Bvt. Maj.-Gen. E. O. C. Ord, commanding the 4th Military District of Arkansas, directed Governor Murphy to notify the members of the "provisional Legislature" that their reconvening was incompatible with the recent Act of Congress. Against this order the Democratic members of the Legislature protested in the following language: ${ }^{7}$

"Now, while we, the members of such Legislature, will obey the order of General Ord, and will not attempt to meet again as such Legislature, yet we respectfully but earnestly protest against any legal right or power in General Ord to prevent the meeting of such Legislature, and that his order to that effect we claim to be unconstitutional and illegal, as also do we claim the order of Isaac Murphy, based on the request or direction of General Ord as aforesaid. We claim and insist that such Legislature was and is in no sense 'provisional,' but the Legislature of the State of Arkansas, created and elected according to the forms of law and the Constitution, and as such has a right to meet at the time to which it adjourned, in July next ...."

This response by the Legislature to General Ord's order clearly showed that it was the policy of the Demo- 
cratic party in Arkansas to adhere to the attitude of the National Democratic Convention, that "we regard the Reconstruction Acts (so called) of Congress, as such, as usurpations, and unconstitutional, revolutionary, and void." 8

The General Government, when it forbade the reassembling of the Provisional Legislature, could have saved the State from violent conditions leading to bloodshed had it disbanded, forcibly if necessary, the entire Provisional Government and appointed another in its place.

Instead, it slept upon its rights and permitted the "Provisional Government" to organize an insurrection against a sovereign and coördinate State of the American Union, and defiantly to adhere to the exercise of powers that never did belong to it. The decision of the Supreme Court in the case of Texas vs. White ${ }^{9}$ left the Democratic party without a leg to stand on, but with a record sullied beyond repair.

ORGANIZATION OF THE REPUBLICAN PARTY IN ARKANSAS

During all of these occurrences I had taken no part in politics but had devoted my time entirely to my plantation. However, my Union sentiments were well known and my Confederate neighbors began to show their antagonism to me by the wanton destruction of my property.

It will be remembered that, from the disclosures of Colonel Willoughby Williams, I was fully aware of their schemes to retain the Government of Arkansas, and I realized that unless some method was found to check their malevolence, a Union man could not live in the State in peace. Hence, I obtained the coöperation of the leading Union men there and a convention was called 
for the purpose of organizing a party in harmony with the General Government.

On April 2, I 867, the Union Convention assembled at Little Rock and nominated a State ticket. During the canvass of the State an amusing incident occurred at Bentonville, Benton County. I was awakened about daylight by a fusillade of fire-arms. Upon inquiring I was told that the citizens were firing off their pistols preparatory to cleaning them for the day. Upon this occasion Judge Yonley and myself were the speakers. According to the program he was to make the first speech.

The meeting was held in a large, empty warehouse, with a goods box at one end, from which we were to speak. When Judge Yonley, who was as true as steel but not aggressive, mounted the box he saw in front of him about five or six feet distant a man standing as straight as an Indian. His coat was of a grayish color and was buttoned up to his chin. Strapped around his waist, in full view, were two navy revolvers. In this position he rigidly stood during the whole of Judge Yonley's speech and watched him closely.

The suspicious appearance of the man so disconcerted Yonley that he made a great failure in his speech, from which he endeavored to eliminate everything that might give offense to the other side. I could see the great drops of perspiration rolling down his face as he proceeded. His speech was short and was received in silence by the audience.

When he had finished I mounted the box and delivered my usual speech, but I kept this man in the corner of my eye for I, too, regarded him with suspicion. When I got down from the stand he came up to me and shook hands cordially and remarked: "These damned Rebels said you should not speak here to-day, but, by G-d, I intended that you should!" 
It was not until the next day that Judge Yonley. knew the facts, when I told the story with some harmless embellishments, much to the amusement of our audience.

I was very active during the entire canvass and when the State election was held, under the Reconstruction Acts of Congress, I was elected Governor of the State.

\section{FOOTNOTES FOR CHAPTER II}

1 Pp. 355 and 357.

${ }^{2}$ Journal of the Convention, Arkansas, I 864.

${ }^{3}$ Complete works of Abraham Lincoln, Vol. IX, pp. 277, 296, 304 .

${ }^{4}$ Complete works of Abraham Lincoln, Vol. X, pp. 8, I I, I39.

${ }^{5}$ Arkansas Senate Journal, r 866-67, p. 300.

${ }^{6}$ Arkansas House Journal, I 866-67, pp. 392-397.

${ }^{7}$ Arkansas Daily Gazette, extract from editorial, May I8, 1867 .

${ }^{8}$ Eighth plank of Democratic National Convention, New York, July, r 868, pp. 367-368, McPherson's "History of Reconstruction."

9 P. I66. 


\section{CHAPTER III}

MY FIRST MESSAGE TO THE GENERAL ASSEMBLY DELIVERED JULY 3, I 868

A description of conditions then existing and an outline of my administrative policies were expressed in my first message to the Legislature, which read as follows: ${ }^{1}$

"Fellow-Citizens of the Senate and House of RePresentatives: Seven years have elapsed since the last State Legislature convened in these halls, - seven short years compared with the lifetime of a State, yet how long when measured by the amount of human misery that has been condensed within that period! When that body met, peace and plenty reigned everywhere, the granaries of the State were literally overflowing, and that part of the community that controlled its destinies was the favored recipient of wealth and prosperity. Protected and fostered by that government that gave the State existence, defended in every constitutional right, with no disposition to interfere with the institutions of the State, though some of them were manifestly unjust and antagonistic to the spirit of our government, it was surely a strange frenzy that drove the people to cut loose from the safe moorings of the Union and launch out amid the rocks and breakers of rebellion. But how different have the results been from those anticipated! The great blot of human slavery that so long defaced our national escutcheon,- - a blot that the statesmen of the past have labored in vain to remove,- - has by an overruling Providence been forever wiped out through 
the very agencies that sought to perpetuate it. Indeed "There is a Divinity that shapes our ends, rough hew them as we may!' I thank God that the work is done, - that the long agony is over,-and that the representatives of the people are again permitted peaceably to assemble within the legislative halls of the State under the starry flag of that country that is now indeed and in truth 'The land of the free and the home of the brave.'

"The duties and responsibilities that you have assumed are most difficult and grave. Much is expected of you. The eyes of the friends of civil liberty everywhere are fixed anxiously upon you. Many of your honorable body have risked your lives upon the battlefield in the service of your country. All have, perhaps, sacrificed much in the same cause. The people will expect you to show the same devotion for the public welfare in the future as you have in the past. With the passions, prejudices, and animosities that have grown out of the civil conflict through which we have passed we should have nothing to do, except to provide for and encourage their allayment. Selfish motives and individual interests should be laid aside, and a desire to promote the public welfare should prompt every official action. An industrious and careful application should be given to the public service that undue and hasty legislation may be avoided. In the appropriation of the public funds true economy should be observed, as distinguished from a mean and niggardly policy.

"The evils of past legislation should be at once corrected and immediate steps should be taken to preserve the public peace and enforce the laws. The body politic has been prostrated by a terrible malady, and rest and careful nursing are required for a time before the great work of development can be undertaken. In our present weak, disordered, and impoverished condition, is there not danger of too much legislation? After repairing and remodeling such parts of the intricate ma- 
chinery of state government as are known to produce friction, let us put it in motion and carefully note its action. A practical test will doubtless suggest much that theory might overlook or misapply.

"I respectfully suggest that after making such enactments as the present demands and the new order of things require you take a recess until after the fall elections. This will enable you to act upon the submission of the question to the people of loaning the credit of the State for the encouragement of railroads, to which your attention will hereafter be more fully invited; will permit such of your honorable body as are engaged in agricultural pursuits, upon the success of which so much depends, to give your personal attention to your crops at this critical season, and will enable you to confer with your constituents and properly investigate the great questions of public policy that will require action upon your re-assembling. Should Providence bless us with abundant crops, as the prospects now indicate, and peace and good order be restored to the State, we may safely commence the grand march of improvement.

"Believing that you will adopt this course, I now propose to call your attention to such measures as, in my judgment, require immediate action.

\section{MILITIA}

"The fathers of the republic have declared and experience has proved that 'The bulwark of our liberties is our citizen soldiery.' Under the peculiar circumstances of the present, the public safety absolutely demands that you should proceed at once to provide for an efficient and well-disciplined militia. The military force should, in my opinion, be composed of two classes. The first class should embrace such able-bodied electors and young men between the ages of eighteen and twenty-one as voluntarily uniform themselves and offer their services to the State, to be officered, organized, and armed under the 
direction of th: commander-in-chief. The second class should embrace "ll able-bodied electors not organized in the first class, who should be enrolled, and at the discretion of the commander-in-chief, organized and armed.

\section{REGISTRATION AND ELECTION LAWS}

"The constitution fixes the qualifications of electors. Steps should be taken to enable all who are authorized to exercise the elective franchise to do so freely and without restraint, and to prevent the improper exercise of that privilege. This must be done through wise registration and election laws, which are both very important, and should receive your early attention.

"I recommend that the county officers having in charge registration be required, in addition to that duty, to enroll the militia. This will save the expense of detailing officers for that service, and will be as efficient.

"That the will of the people is the supreme law is a principle of government that underlies our free institutions. He, therefore, who would willfully defeat the true expression of that will, by deterring a citizen from the exercise of the elective franchise, or by defrauding him of his vote, strikes a blow at the foundations of the government itself and merits the severe pains and penalties of an outraged law.

"In view of the fall elections you should, at an early day, by the enactment of a wise and rigorous election law, put into the hands of the executive officers of the State ample authority for the protection of every qualified elector in the free expression of his preference at the ballot box.

\section{IMMIGRATION}

"There is probably no question that will affect the future destiny of Arkansas so much as that of immigration.

"Providence has richly endowed our State with those 
elements of wealth that are necessary to constitute an independent and self-supporting community. Yet, in the midst of this great age of progress and improvement, our primeval forests, as of yore, rear their arms to Heaven and seem to defy the hand of man. Millions of broad acres, teeming with fatness and fertile beyond description, patiently await the 'open sesame' that shall unlock and develop their varied stores. Limitless wealth buried under broad hills, concealed in secluded valleys, and hidden in mountain caves awaits the glad advent of the pick and bar.

"Reflecting upon our great agricultural staple, we involuntarily pause to listen for the hum of machinery and the clank of the loom.

"After a patient waiting of half a century the light of a higher civilization has burst upon Arkansas.

"The vast tide of immigration that from across the waters has been moving westward for so many years, peopling territories, building cities, and creating States with magical rapidity, - only awaits our action to pour itself within the limits of our State.

"We should invite all classes to come here and we should greet everyone with a cordial welcome. Capital should be protected, industry fostered, and over each individual should be extended the strong and protecting arm of the law,-guaranteeing, upon the soil of Arkansas, equal rights to all men.

"I confidently expect that at an early period you will establish a liberal and vigorous bureau of immigration; and I earnestly recommend that you so define the duties of the commissioner and clothe him with such powers in relation to his intercourse with the most populous parts of this and foreign countries as shall enable him to cope successfully with the agents of other States, and to direct the capital and labor of the North to this more genial climate, and by a thorough diffusion of facts and statistics so to determine the line of immigration from Europe to this State as to make us the recipients of those 
elements of wealth and prosperity from which, by the old order of things, we were effectually debarred.

\section{RAILROADS}

"Closely connected with the question of immigration are our railroad interests. The immigrant in seeking and locating his new home is apt to follow railroad lines. And whilst it is true that our noble rivers, which spread over our State like great arteries, afford a natural means of intercommunication unsurpassed by any other State, they are insufficient, and, for travelling purposes, must soon give way to railroad communication.

"The very act of constructing our railroads will bring into our State thousands of laborers, who will soon discover superior inducements to stay among us; and by communicating with their friends will produce a flow of immigration which, once started, will rapidly increase.

"But I need make no arguments in favor of railroads, for I believe your honorable and intelligent body is fully convinced of their great value and importance. They are themselves existing witnesses of their wealthgiving power, for wherever they reach out their iron arms the seeds of prosperity are rapidly disseminated; wherever the shrill voice of the 'iron horse' is heard every branch of industry is stimulated; along the tracks upon which he courses the forests disappear, the rough face of nature is smoothed down, and farms, villages, towns, and cities spring up as if by magic; as each successive train sweeps by, laden with the varied merchandise of every clime, far out to the right and left is disseminated information for the people,-information that educates as well as enriches.

"Can we do anything at this time to encourage this great interest that brings with it so many blessings? There is one important step that I believe we can and we should take in that direction. A railroad bill should be passed before you adjourn that will provide for the loan- 
ing of the credit of the State to such roads as are now, or may hereafter, be incorporated, that shall be shown to be of sufficient benefit to the State to justify such loan, and that may not have received from the general government, by grant of lands or otherwise, sufficient assistance to insure the completion of the same without the aid of the State. The Constitution of the State wisely provides that the credit of the State shall never be loaned without the consent of the people expressed at the ballot-box. The question should therefore be submitted to the people at the fall elections, which will enable you upon your re-assembling to take such action as the results may demand.

"It is not expected that you will create fresh indebtedness by the issuance of bonds whilst our credit is in its present condition, unless the exigencies of the State government should require it.

"I am indebted to Gen. M. Brayman, President of the Cairo and Fulton Railroad Company, for an able and concise statement of the history and condition of that corporation. This document will be submitted to you for your information.

\section{OUR PRESENT INDEBTEDNESS}

"Whilst every principle of justice and honor demands that we should, at as early a period as practicable, settle every honest debt, no matter when contracted, the public interest requires that we should take sufficient time to investigate thoroughly claims that originated so many years ago, and at a period that seems to have been marked by a degree of official corruption and misrule probably unprecedented in the history of any other State.

"I shall make the investigation of this important subject my especial duty, and endeavor to gain, as soon as possible, such information as will enable me to lay before your honorable body, at your re-assembling, such facts and figures as will facilitate your action; and I hope 
to be able at the same time to submit such terms of adjustment as will conform to the interests and honor of the State and satisfy the rights of the public creditor.

\section{EDUCATION}

"Your attention is respectfully invited to a question that is perhaps more important than any other you may be called upon to consider. It is that of universal education. To the ears of the oppressor this is a startling and dangerous subject; for, wherever the ennobling influences of education are felt, the shackles fall from the limbs of the oppressed,- - the slave becomes a freeman. To the lover of freedom it is the very 'philosopher's stone' that changes the base metal of the ignorant and slavish mind to the pure ore upon which the light of liberty is caught and from which it is reflected to other minds until the whole becomes illumined. To us it is the keystone of the grand arch upon which rests the fair structure of our free government. No State founded upon the principles upon which our government is based can prosper where ignorance prevails. The people cannot rule successfully unless they are educated and informed.

"Free schools and free labor are necessary adjuncts -they go hand in hand together. The one produces from the garden of the mind its choicest fruits, the other causes 'the wilderness to blossom as the rose.'

"The wicked and shameful manner in which the servants of the people have neglected their educational interests and appropriated to their own selfish uses and the unhallowed purposes of treason the magnificent endowment of a generous government subjects them to the merited condemnation of all true patriots. In regard to the advancement of the common school interests the question heretofore seems to have been, not how to do it, but how not to do it. A comparison of the condition of common schools in this State,-as shown by Gov- 
ernor Henry Rector's message, delivered to the General Assembly November 15, I 860,-with that of the State of Michigan, which became a member of the Federal Union at the same time with Arkansas, and under circumstances less favorable, is calculated to create a sickening sensation in the breast of one having the interests of education at heart. In 1855 Michigan maintained $3,255 \mathrm{com}$ mon schools, and employed 5,078 teachers. In i 860 , as shown by the message above referred to, but 25 common schools were organized and kept up in this State from the common school fund. J am unable to give you correct information of the number of common schools now in operation, but for practical purposes it would be safe to proceed as if there were none.

"From reliable statistics obtained from the lists of registered voters made last fall it is shown that thirty per cent of the white and fifty per cent of the entire voting population were unable to write their own names. Nothing but a due sense of my constitutional obligations and an earnest desire to promote the educational interests of the State induces me to make this shameful disclosure. Fortunately, after thirty-two years of ignorance and misrule, a way is at last opened through which the light of intelligence can enter and shed its beneficent rays over the whole State.

"The framers of our present Constitution have placed themselves in enviable comparison with past legislators, and merited the approbation and gratitude of posterity by that one act of far-seeing statesmanship that secures to future generations the inestimable boon of education, and gives life and perpetuity to the State by providing the neans whereby its future supporters and defenders may be prepared for the proper exercise of the duties of American citizenship.

"You are expected to take up this work that has been so well begun, and at an early day devise and establish a wise system of free schools, - one that will not be out of proportion with our limited means, but will be so 
adjusted as to grow with our growth and strengthen with our strength. After a system is established, the work of execution should be put into the hands of competent men, depending more upon efficiency than numbers. The work that under the present system is entrusted to nearly sixty officers could, in my opinion, be more efficiently performed by ten. I therefore respectfully suggest the propriety of abolishing the office of county school commissioner, and creating in lieu thereof district superintendents for each judicial district that is now or may hereafter be established. These district superintendents should be charged with the work of organizing school districts and establishing schools; they should have immediate supervision over the school directors of the various school districts and see that said directors perform their duties promptly and according to law; they should examine and license teachers, and organize teachers' institutes; they should provide rules and regulations for the government of schools, and visit the schools frequently for the purpose of ascertaining the efficiency of the teachers, and they should examine the titles of all school lands that have heretofore been disposed of and report to the proper officer such, if any, as are illegally held and their condition. In short, they should have full supervision of all matters pertaining to the school interests in their respective districts.

"In addition to these duties, the district superintendents, with the State Superintendent as presiding officer, should constitute a board of education, which should meet at the capital yearly, and have conferred upon it such legislative powers as may enable said board to make such amendments in the school system as the application of theory to practice or the exigencies of the educational interests may demand.

"The present condition of our school interests is unprecedented. A large portion of the community is known to be antagonistic to the principles of universal education. The prejudices that exist against a certain class 
of the people will tend to embarrass the situation. Obstacles will doubtless be thrown in the way where active support should be given.

"The establishment of the school systems of the older States has been the work of years. We cannot expect successfully to apply at once to our State the elaborate plans that they have slowly perfected and adjusted to suit their enlarged views and peculiar localities and conditions. Before we can arrive at such a degree of perfection the people must be educated as well as the rising generation.

\section{BLIND INSTITUTE}

"Your attention is called to the reports of the "Arkansas Institute for the Blind.' This institution has been maintained at the public expense. In case you create the educational board, as recommended, I would respectfully suggest that you abolish the board of trustees, and put this institution under the control of said educational board.

"It is believed that the institution should be moved from Arkadelphia and located at the Capital. The reasons given for the latter location are that it is more accessible, that supplies can be obtained more conveniently, and that when the legislature is in session the members can more readily acquaint themselves with its condition. If the expenses of making the contemplated change will not be great, I would respectfully recommend it.

\section{GEOLOGICAI, SURVEY}

"For the purpose of bringing to light our great mineral resources and facilitating their development, I respectfully recommend that the Executive be authorized to employ a person skilled in the sciences of geology, mineralogy, and mining, who shall proceed upon the data afforded by the able reconnaissance of Prof. David 
Dale Owen to make a thorough investigation of the various mineral localities of this State. A reasonable sum expended in a scientific investigation of this nature will doubtless bring to light vast resources of hidden wealth, which will not only afford profitable employment to thousands of enterprising artisans, but will add very much to the revenues of the commonwealth.

\section{STATE HOUSE AND GROUNDS}

"Your attention is respectfully called to the condition of the State House. Strangers visiting our Capital would form a very unfavorable opinion of our commonwealth, I fear, should they happen to stroll into that building. The public interest requires that it should be kept in a state of repair, and common decency demands that the halls, corridors, and grounds should be cleansed of the rubbish that now encumbers them.

"Trusting that your deliberations may be harmonious and redound to the public good, and that nothing may occur to disturb or impair the unity and confidence that should exist between the gentlemen of your department and the executive, I respectfully submit the foregoing for your consideration.

Powell Clayton, Governor."

FOOTNOTE FOR CHAPTER III

${ }^{1}$ Arkansas House Journal, I 868, pp. 290-300. 


\title{
CHAPTER IV
}

\author{
REGISTRATION
}

The Law of Arkansas, fixing the qualifications of registered voters, was as follows:

"No person shall be registered who during the late rebellion took the oath of allegiance to the United States, or gave bond of loyalty or for good behavior, unless he shall show by satisfactory evidence that he has ever kept this said oath or bond inviolate, or that he has openly advocated or voted for the reconstruction measures of Congress, or voted for the constitution at the civil polls at the Constitutional election of I $868 . " 1$

Because of the large number of ex-Confederate soldiers who were thus disfranchised the execution of this law proved to be a source of highly insurrectionary and irreconcilable contentions.

The Board of Registration in each county consisted of three members, one of whom was styled "president" and the others were known as "registrars." For the comparatively short period of their employment these officers were to receive six dollars a day, and because of the temporary character of the work and of the small compensation, it was almost impossible to secure efficient officers to perform these very unpopular and dangerous duties.

Therefore many registrars practically threw the registration books open to all, while others who rigidly 
performed their duties were subjected to great danger, even to assassination, as in the case of Capt. Simpson Mason, registrar of Fulton County, who, while riding along the road to the place of registration, was fired upon and killed by a body of men in ambush. ${ }^{2}$

This crime was soon followed by the attempted assassination and wounding of F. A. McClure, registrar of Woodruff County; the severe wounding of Gen. D. P. Upham, ${ }^{3}$ who was accompanying him to the place of registration (whether in an official capacity or not I am unable to state), and many other outrages against the registrars which caused the registering officers in twelve counties to resign. This action upon their part made it impossible for an election to be held in those counties, as the period between their resignation and the date fixed by the Constitution for the holding of the election was not sufficient to permit the publication and preliminary action required by law. ${ }^{4}$

To avoid the legal effects of disfranchisement, the Gazette, the organ of the Democratic Party, and other Democratic newspapers in the State, urged those who were disfranchised to overcome all scruples and perjure themselves by taking this oath. In support of this advice they used the most fallacious and illogical arguments, which, if acted upon, would not only have caused the person so acting to commit the crime of perjury, but would have subjected him, under the law then in force, to the penalty of imprisonment in the penitentiary for from two to five years.

To illustrate their advice, I reproduce from a mass of similar matter the following extracts from the Gazette:

"[August 30, I 868. Extract from Editorial.] A 'case of conscience' is thrust upon us by our dissenting 
friends. Let them weigh in their nicest scales of high morality the alternatives as above depicted, and answer if it is not a more monstrous crime to continue the radicals in power by refusing the oath than to eject them and install Democrats by taking it?

"Shipwrecked,- - an angry sea threatening to devour us, - pirates bearing down upon us to torture and kill, - may we not righteously take any oath that saves from such perils?

"[August I, I 868. Extract from Editorial.] Now it has become necessary for self-preservation, a right enjoyed by the lowest of the animal kingdom, for such of our people as can do so to take this oath and vote in the coming election. Our state central committee has so advised. We presume there are none among us who will not see the necessity of this course, and trust that none, - no, not one,-will object to taking this oath. . . . In cases of this sort it has always been conceded that it is right to swear, and violate the pledge at the first temple of justice. We trust that from some of these or like considerations our people will all find it possible to come forward, take the oath, and vote for Seymour and Blair. It is a sacred duty we owe future generations. Nor will it matter for the purposes of the fall election what may have been the individual construction put upon the oath by those who accept it. Any differences of that sort may be settled in future, and need not embarrass the present.

"[August 4, I868. Editorial.] In regard to the propriety of urging our people to take the oath, we will say frankly that we have not the time nor disposition just now to discuss the ethics of the subject. We are firm believers in the saving grace of the Christian religion, and it is never too late to found a hope of ultimate salvation there, let our course political be what it may. As a general thing we hold to the opinion that an honest man's politics and religion are not distantly related. In the present political struggle we believe that the end we seek will justify the use of ANY means." 
So shocking was this advice as to call forth from Gen. Albert Pike, - at that time the head of the Masonic Fraternity and a leading Democrat, a man whose lifesize statue is accorded a prominent place at the National Capital among the distinguished citizens of America,a severe stricture, published in the Memphis Appeal, September 10, I868, from which I quote as follows:

"Some gentlemen, and among the rest Col. J. M. Harrell, of Little Rock [editor of the Little Rock $G a$ zette], are laying up for themselves 'wrath against the day of wrath.' We shall be at liberty to speak by and by. It is but a little more than two months to the day of election in November, after which no pledge of honor to party will any longer seal up our mouths. Wait and see!. . . It seems to be the ambition of many political leaders to be damned by advising people oppressed by calamity to take the ways that lead directly downward to the hell of dishonor. We do not wonder that they point the people to the present profit that they are to reap as the fruit of crime.

"No sophistry can disguise the fact that for one to swear that he will never attempt to deprive any negro of the right to vote, with the settled intention to change the Constitution of the State as soon as possible, so that this oath shall be no longer required, and to elect legislators who will deprive the negro of the right of suffrage, is to swear with the purpose of perjury determined on. No such oath was taken, because no such oath was required in Maryland. It is not standing on dead issues to advise the people not to do a shameful act, which will be hardly done ere it will be repented of in sackcloth and ashes. The man who advises the people to such a course will indeed 'build his coffin,' and find death a relief from the ignominy that will overwhelm all such counsellors.

" 'I will be a swift witness against the false swearers, saith the Lord of Hosts.' 'They have spoken words, 
swearing falsely in making a covenant; thus judgment springeth up as hemlock in the furrows of the field.'

"It is men who are deceivers, - not the devil. The first and worst fraud of all is to cheat one's self. All $\sin$ is easy after that.

"If the people of Arkansas permit themselves to be led into the great $\sin$ and shame to which they are tempted, they will cheat themselves, and afterwards find that no permanent profit or advantage can be reaped by a people from an act for which its own conscience will in vain labor to find a sufficient excuse. That which is right and just and true is only profitable in the end to man or nations."

Kindred to the foregoing question is the advice given by the Gasctte, to its party adherents, from which I quote as follows :

"[August 8, I 868. Extract from Editorial.] An act defining the qualifications of jurors. ${ }^{5}$

"Section I. Be it enacted by the General Assembly of the State of Arkansas, That all qualified electors of this State, and none others, shall be competent jurors.

"Section 2. Be it further enacted, That all laws and parts of laws in conflict with this act are hereby repealed, and that this act take effect and be in force from and after its passage.

"Such a high-handed outrage upon the rights of nien, and so flagrant a violation of long established precedent, needs no comment. It is enough to know that the future existence in Arkansas of those who may chance to differ with the radical party is rendered impossible, unless the power that attempts to enforce this law is broken up. Let the word go forth that this shall be done. IT IS OUR ONLY SAFETY, AND JUSTIFIES ANY MEANS.'

So the "Organ," speaking for its party, advised the commission of every crime punishable by the laws of God or man for the accomplishment of its base political 


\section{CIVIL WAR, IN ARKANSAS}

purposes. These startling announcements are too clearly expressed to require any elucidation upon my part, and they completely justified the wisdom of the Constitutional Convention in its efforts to debar from suffrage persons entertaining such atrocious sentiments.

\section{FOOTNOTES FOR CHAPTER IV}

${ }^{1}$ See Arkansas Laws, I868, p. 55, Sec. Ir.

2 See p. 90.

3 Arkansas Gazette, October I 4, I 868.

${ }^{4}$ See Arkansas Laws, I 868, pp. 52-60.

${ }^{5}$ See Arkansas Laws, I868, p. 35. 


\section{CHAPTER V}

ORGANIZATION AND OPERATIONS OF KU KLUX KLAN IN ARKANSAS

Soon came whisperings of a mysterious secret order, followed by reports from several parts of the State of "night-riders." It was said that the horses and the men were concealed by masks, gowns, and trappings made of black calico bespangled with glittering, metallic, cabalistic designs.

About the same time reports came to me from members of the Legislature and other public officials of the receipt of warnings left at night by unknown hands in familiar places, written in a peculiar vocabulary, urging them to desist in their political activities and leave the country or suffer the dire consequences of Ku Klux vengeance. The following Ku Klux proclamation was found posted on a tree in Pine Bluff, Ark., and was published in the Republican, April 6, I868:

"K. K. K.

"SPECIAL ORDER NO. 2

"Corinth Division, "Pine Bluff Retreat.

"Spirit Brothers; Shadows of Martyrs; Phantoms from gory fields; Followers of Brutus!!!!!! Rally, rally, rally.-When shadows gather, moons grow dim, and stars tremble glide to the Council Hall and wash your hands in tyrants' blood; and gaze upon the list of 
condemned traitors. The time has arrived. Blood must flow. The true must be saved.

"Work in darkness.

"Bury in waters.

"Make no sound.

"Trust not the air.

"Strike high and sure.

"Vengeance! Vengeance! Vengeance!

"Tried, condemned. Execute well. Fear is dead. Every man is a Judge and this Executes. ! ! ! ! ! Fail Not. ! ! Mandate of the M. G. C." By D. M. G. C. $12 \mathrm{~m} \mathrm{p} 2$.

On the 9 th of September while hunting near Little Rock I had the misfortune to lose my left hand by the accidental discharge of my gun. One night shortly after the amputation word came to my bedside that in the anteroom there was a mysterious stranger who insisted on seeing me alone, "upon very important business." My first impulse was to decline to see the man, but instinctively I changed my mind and ordered him to be admitted. When he opened the door he looked cautiously around, then said, "Governor, is there anybody who can hear what I want to say to you?" I replied, "You can speak with safety."

He commenced by giving me his name and place of residence, and by saying that he could impart to me valuable information relative to the Ku Klux organization in Arkansas. He proposed that after he had fully conveyed to me this information, if I should consider it of sufficient value, I should supply him with about $\$ 300$ to enable him to remove himself and his family from the State. On the other hand, he would require my solemn pledge that I would not, at any time or under any circumstances, divulge his name as my informant. 
As his proposition seemed reasonable I readily consented to it. He then informed me that he was the cyclops of a certain $\mathrm{Ku}$ Klux den in Independence County; that he joined the Klan believing its purposes to be protective against negro aggression, and politically a harmless adjunct to the Democratic Party in its efforts to carry the forthcoming election; but its usurpations of powers, including those that controlled life and death, and the shocking outrages committed by it throughout the State had convinced him that the day of exposure was near, and that when that day came he intended, with his family, to be safely located beyond the jurisdiction of the State and the reach of the long arm of the avenging Klan.

He first gave me a printed copy of the Ku Klux ritual and explained its provisions. He also informed me of some of the Klan's operations in the neighboring county of White. He, in short, placed me in possession of such information as would enable my secret agents to gain admittance to dens in the State. He did not ask for any money until his information should be verified by the admittance of one of my agents to a den in the City of Little Rock or elsewhere. This being so far satisfactory, I put him in communication with Adjt.-Gen. Keyes Danforth, with the understanding that he should give Danforth all the information he possessed.

The Ku Klux Klan was organized by General Forrest in Memphis, Tenn., a year before my inauguration. Before the war he had been a negro overseer and a slave trader of the lowest type, and was not recognized socially by the planters. Indeed, he was a fitting leader for this foul organization. It was not until I was visited by the "mysterious stranger" that I had full knowledge of its existence. Bearing upon its organization and purposes, I refer the reader to the following extract from the 
Arkansas Daily Gazette of August I I, I9 I I, based upon an interview with Gen. R. G. Shaver:

\section{"WAS WIZARD IN ARKANSAS}

"General Shaver was Wizard of Ku Klux in this State, and was present at the organization of the order in Memphis, Tenn., in I 867 . The name 'Ku Klux' was taken from the local Tennessee organization of similar purpose, or rather, bestowed upon it later, and the original cognomen adopted at the initial meeting was 'The Order of the White Man.' Together with Gen. Nathan Bedford Forrest, the late General Gordon, and many other distinguished leaders of the Confederacy, General Shaver, of Arkansas, met in Memphis shortly after the practical disfranchisement of the white man in the South to devise a means of taking the law in their own hands for the preservation of a government by the whites. Although there were assembled scores upon scores of the best known men in the South, both civil and military, with such secrecy was the meeting conducted that a majority of the Memphians, even, knew nothing of it. General Shaver served on the Tactical Committee, and was very active in the organization.

\section{"KLAN WAS PURELY MILITARY}

"After a meeting of about a week's duration the plans were perfected. The order was named, with General Forrest as commander-in-chief, or grand wizard, at the head, and with absolute military authority. In passing, the Klan was purely military, and not until its disbanding and subsequent illegitimate reorganization did it usurp powers either civil or political. The names of the officers were, after the commander-in-chief, who was the grand wizard: the wizard, State commander; grand titian, second in State command; titian, third; grand cyclops, equivalent to a brigade commander; cyclops, county commander; and mogul, company commander. A com- 
pany's meeting place was called a 'den.' The uniform of the order was a black shroud both for man and horse, with tin stars, half moons, etc., sewed upon it. None but Confederate soldiers in good standing and their sons from eighteen years up were admitted without securing dispensation from the grand wizard. General Shaver stated that he frequently secured dispensations in order that he might admit telegraph operators, by that means securing the wire which was held entirely by the Klan north of Little Rock. The meetings were always held at dead of night and in dense woods; the Klan never at any time gathered in a house, no matter what the weather.

\section{"I 5,OOO ARMED MEN AT HIS CALL}

"Among the dens organized in Arkansas were those at Washington, Camden, Eldorado, Monticello, and other places, and General Shaver stated yesterday that at the time of disbanding, pursuant to the order of the grand wizard, he had I5,00o armed men in Arkansas ready to assemble at his call. Incidentally, while it is known to but few, the recapture of Little Rock by the $\mathrm{Ku}$ Klux was planned, when suspension orders were issued by General Forrest.

"Among the cyclops of southern Arkansas was Gen. James F. Smith, of Little Rock, who was very instrumental in breaking up the Negro League meetings in Hempstead and surrounding counties.

"'That was where I shone,' said the General yesterday in recounting an instance in which an unusually large gathering was broken up without the uttering of a word or the firing of a gun.

\section{"INVISIBLE EMPIRE DISSOLVES}

"However, with the quieting of the situation and the inclination of the lawless element to exceed the good purposes for which the Klan was organized, it was 
deemed best to disband, and in the investigation that followed, General Shaver, because of a traitor in his ranks, was forced to flee to Honduras for his life.

"So, the Ku Klux Klan, the invisible empire, rose and fell in its incipiency, when Anglo-Saxon supremacy was its watchword and guiding star, one of the greatest organizations ever formed, and in its later days when outlaws and libertines broke in to use it as a vehicle for personal and political prejudice, one of the worst. But although the latter breed masqueraded under the name and insignia of the Klan, they were never of it. Knighthood in the order was kept pure to the last, and its doors were locked against the outsider as fast as the inviolate secret of its oath of blood is kept in the breasts of those who rode beneath its banner."

General Shaver served gallantly as a brigadier-general in the Confederate army, and he is still living,-a highly respected citizen of Arkansas. In the militia operations for the suppression of the $\mathrm{Ku}$ Klux he took an open and hostile part. It would be interesting to know who betrayed General Shaver and thus caused him to take refuge in Honduras.

During the early stages of the $\mathrm{Ku}$ Klux operations I was inclined to believe that the doings of the Klan were but Democratic devices to intimidate the negroes and prevent them from registering and voting at the forthcoming presidential election; but, as my administration progressed, reports kept coming to me of assassinations and outrages perpetrated upon Republicans alone, and, in most cases, State officials. Up to the time of the disclosures of the man whom I shall hereafter speak of as the "mysterious stranger," all my efforts through the employment of secret service agents and the offering of large rewards to pierce the impenetrable veil had proved futile. 
It so happened that a few days before the "stranger's" visit Albert H. Parker came to Little Rock seeking employment, with a highly commendatory letter to me from the Major of my old regiment, Samuel Walker. Mr. Parker was the brother of David B. Parker, for many years Chief Inspector of the Post Office Department at Washington, D. C. Before the war Albert H. Parker had settled in Texas, and when the great storm of secession broke out he, like many others, was swept into its vortex and became a soldier in the Confederate Army, serving, as I remember, until the end of the war, after which he went to Lawrence, Kan., where he lived until he became involved in the tragic events I shall hereafter relate.

In due time General Danforth informed me that all tests of the "mysterious stranger's" reliability had been satisfactorily made, so I brought Danforth and Parker together with the view of having the former instruct the latter in all the details necessary to enable him, as the secret agent of the Government, to perform his duties successfully.

I assigned him to White County to investigate thoroughly the $\mathrm{Ku}$ Klux operations there and especially the attempted assassination, wounding, and robbing of State Senator Stephen Wheeler, ${ }^{1}$ as well as the assassination of Ban Humphries, ${ }^{2}$ an intelligent and very influential colored leader; and other outrages reported to me from that county. In assigning Parker to this work, after having portrayed in the strongest language at my command its dangerous character, I left it with him to devise a pretext for his appearance in White County. He pretended that he was preparing for the collection of cattle from Texas and other southern points, to be assembled in Arkansas at a place where grazing and other necessities were advantageous, to be distributed event- 
ually to northern markets where high prices prevailed. This pretext was very good for a comparatively short time, but his failure to assemble his droves of cattle there naturally caused suspicion and that should have induced him to report to me at once for further instructions.

I also organized a secret service force of eleven detectives in addition to Parker. Of course, these agents were brought from without the State, and some, like Parker, had Confederate records that enabled them the more readily to perform their duties, which were to gain access to the $\mathrm{Ku}$ Klux dens of the localities assigned to them and to inform me as fully and as quickly as possible of the conditions existing in each. The majority of these agents were successful. For reasons that will soon appear I received no report from Parker.

\section{ORGANIZATION OF THE STATE MILITIA}

Having received reports from these detectives and information from many other sources, I determined to make a square issue between the State government and the Ku Klux insurgents in Arkansas. I issued immediate instructions to the officers of the State Militia to proceed with the utmost secrecy and dispatch in the further organization of the State Guards, and on the 4 th of November, I868, I issued my proclamation declaring martial law in the counties enumerated therein, a copy of which follows: ${ }^{3}$

"Whereas, The Counties of Ashley, Bradley, Columbia, Lafayette, Mississippi, Woodruff, Craighead, Greene, Sevier, and Little River are in a state of insurrection and the civil authority is utterly powerless to preserve order and to protect the lives of the citizens; unauthorized bodies of armed men (in most cases disguised) are engaged in acts of lawlessness and violence; the county officers have either been killed or driven away 
from their homes; or intimidated in the performance of their duties; the quiet and law-abiding citizens in many instances have not been allowed an expression of their sentiments, or the exercise of their duties and privileges as citizens, and, while hundreds of them have been murdered, in no instance known to the Executive have the assassins been brought to punishment by the civil authorities; the State is being invaded by bands of outlaws from Texas and Louisiana who are committing murders and depredations upon the citizens; the registration laws could not be fairly executed, and were necessarily set aside; and in many of these counties a perfect reign of terror now exists, and

"Whereas, This deplorable state of affairs is, to a great extent, attributable to the existence of a secret organization, military in its character, styled 'Knights of the White Camelia,' but more popularly known as the 'Ku Klux Klan,' whose object is treasonable and murderous and subversive of all government; and this organization while it declares in article 76 of its constitution that 'the order shall not as a body nominate, adopt, or support any candidate or set of candidates, for any office of honor, profit, or trust, under the Constitution and laws of the United States,' thereby professedly disclaiming all political character, is at the same time plotting to overturn the State Government, which they hope to accomplish by creating vacancies in office by assassination and intimidation, thereby preventing the loyal citizens from filling the offices thus made vacant, and from performing the necessary duties of citizenship and rendering the State Government inoperative.

"It is believed that many of the law-abiding people of the State have become members of this band through ignorance of its real character and misapprehension of its diabolical designs, or for the purpose of obtaining protection for themselves and their property; all such persons are advised at once to abandon this organization and purge themselves of all connection with it. 
"NOW, THEREFORE, I, POWELL CLAYTON, Governor of the State of Arkansas, do hereby proclaim martial law in the aforementioned counties. All unlawful organizations will, upon the receipt of this proclamation, or notice of the same, at once disband and abstain from all illegal and violent acts. All who fail to do this will be treated as outlaws, and not entitled to the protection of the Government, and will certainly be brought to speedy and merited punishment; and all bodies of armed men (not organized in pursuance of the laws of the State and the United States) will at once disperse and return to their homes; and I hereby call upon and request all law-abiding citizens to use their influence to prevent disorder and preserve the public peace. Citizens of the counties not under Martial Law are requested to abstain from all unauthorized military organizations, or from any interference in the affairs of other counties. Unless this is done Martial Law will be extended to them, and war, with all its horrors, may be precipitated upon the State, which is still suffering terribly from the former rebellion.

"Those who participated therein are admonished that to engage in a second rebellion would in all probability preclude the hope of their obtaining mercy from the State or general government.

"All officers of the State Guards will at once perfect their organizations and hold themselves in readiness to respond to the orders of the Commander-in-Chief; and all well disposed persons not members of the State Guards are earnestly urged to volunteer their services to the support of the Government.

"In Testimony Whereof, I have hereunto set my hand, and caused the Seal of (SEAL) the State of Arkansas to be affixed at the City of Little Rock, on the 4th day of November, A. D. I 868.

\section{"Powell Clayton, Governor.}

"By the Governor:

"Robert J. T. White,

"Secretary of State." 
Generals Catterson and Upham were commissioned Brigadier-Generals and Samuel W. Mallory, Colonel, of the State Guards, and under the provisions of General Orders No. 8 (a copy of which follows) ${ }^{4}$ they were assigned to the military districts named therein. These offcers immediately assumed command and entered energetically upon their duties.

"General Headquarters, State of Arkansas, "Adjutant-General's Office, "Little Rock, Ark., Nov. 7, r 868.

"General Orders

"No. VIII.

"I. The Districts created by General Orders No. II are hereby abolished.

"II. For the purpose of perfecting the organization of the Militia, and carrying into effect the Governor's Proclamation declaring Martial Law in several counties of this State, the following Military Districts are hereby established.

"III. District of the Southwest will comprise the counties of Sebastian, Scott, Yell, Perry, Pulaski, Polk, Montgomery, Hot Springs, Saline, Sevier, Pike, Clark, Dallas, Little River, Hempstead, Ouachita, Calhoun, Lafayette, Columbia, and Union, commanded by Brig.Gen. Robert F. Catterson.

"IV. District of the Northwest will comprise the counties of Crawford, Franklin, Johnson, Pope, Conway, Van Buren, Searcy, Newton, Madison, Washington, Benton, Carroll, and Marion.

"V. District of the Northeast will comprise the counties of Fulton, Lawrence, Sharp, Randolph, Greene, Izard, Independence, Jackson, Craighead, Poinsett, Mississippi, White, Woodruff, Cross, St. Francis, Crittenden, Prairie, Monroe, Phillips, and that portion of Desha lying north of White River, commanded by Brig.Gen. D. P. Upham. 
"VI. District of the Southeast will comprise the counties of Arkansas, Ashley, Jefferson, Bradley, Drew, Chicot, and that portion of Desha lying south of White River, commanded by Col. Samuel Mallory.

"VII. Commanders of the Southwestern, Southeastern, and Northeastern Districts will immediately proceed to occupy the counties that are under Martial Law, with sufficient troops to enforce the same.

"VIII. In addition to the State Guards, they will organize the reserve militia, from which they are authorized to draft, in case a sufficient volunteer force cannot be obtained.

"IX. A commanding officer of the Northwestern District will be announced in future orders. In the meantime all officers of the State Guards in that District will complete the organization of their companies, and hold themselves in readiness to fill such details as may be made upon them.

"X. Officers and troops in counties not under martial law must be subservient to the civil authorities, and in passing through such counties will in no way violate the rights of persons or property.

"XI. District Commanders will report all important action to these Headquarters.

"By order of the Commander-in-Chief, "Keyes Danforth, "Adjutant-General."

The General Assembly convened for its second session on the 17 th of November, I868. On the $24^{\text {th }}$ of November I communicated to it my message, from which I quote as follows: ${ }^{5}$

"By the Constitution the duty devolves upon the Executive 'to give to the General Assembly information, by message, concerning the condition of the State, and recommend such measures to their consideration as he may deem expedient.' 
"It could not be expected that an extended message would be presented at this time. I can only make a brief reference to some of the most important interests of the State, and some suggestions for your consideration, respectfully referring you to the various reports for further information.

\section{"CONDITION OF THE STATE}

"We are in the midst of civil commotion.

"The policy of the United States Government in withdrawing its support and protection from us upon our re-admission into the Union has had the effect to some extent of placing us in a situation of great peril and difficulty.

"With no greater resources or available means at our disposal than before our State was admitted (when a strong military force was deemed to be absolutely essential to preserve the Union element from those who had not forgotten their hatred to the old flag and their love for the 'lost cause'), we were at once compelled to depend upon ourselves for protection; to battle against difficulties well-nigh insurmountable in our weak condition; to carry on, in the towns and villages and counties throughout the State, a warfare in the defense of our lives and for the cause of freedom.

"The element opposed to the Government has become so much emboldened as to assume offensive operations and to attempt the overthrow of the lawful authority in the State. A deep laid conspiracy was organized for this purpose, and the object was to be accomplished partly by the instrumentality of the treasonable organization, having its ramifications in many parts of the State, which included in its programme of operations assassinations, robberies, threats, and intimidations.

"The fearful history of the last few months, with its dark catalogue of crimes committed, will, in all proba- 
bility, never be entirely disclosed. The publication of all the atrocities and outrages perpetrated would have endangered the lives of those giving information, and would doubtless have led to the destruction of some of them.

"From the great mass of the accounts that have reached me I can only briefly, on the present occasion, refer to a few :

"In Ashley County the sheriff was openly assaulted and personally abused.

"The registrars were driven away.

"The sheriff and clerk were compelled to resign and appoint deputies to save their lives.

"Several colored men were taken out, beaten, and threatened to be hung. Several others missing, supposed to be killed.

"Moses Dean and his wife found in the woods since that, hung.

"A freedman, hauling cotton, was shot dead in the road.

"In Columbia County the people were advised publicly to force the registrars to place their names on the registration books, and if the tax collectors should come to their houses, to send them out feet foremost.

"Five men were killed in ten days. Three of them killed in the field, and rolled into one hole.

"Aaron Hicks killed. Cause : being a Union man. No fair registration. Armed forces (Ku Klux) riding through the country. The sheriff resisted.

"In Lafayette County there was an organized band of marauders. Several men were killed. Registrar fled to save his life. No civil law.

"In Sevier County the sheriff was abused. A Union man murdered in his own house. Hill, a colored man, brutally murdered. Union men are sleeping in the woods, or driven out of the county. No fair registration. County officers notified to leave.

"In Little River County, Willis and Andrews shot 
down upon the road,-murdered. Sheriff wounded and colored man killed. No law. No fair registration. Constant threats of assassination made.

"In Monroe County, Hon. James M. Hinds, member of Congress, murdered upon the road. At the same time Hon. Joseph Brooks shot down and badly wounded. Other outrages reported.

"In Crittenden County, Ku Klux killed six men in ten days. Other deaths reported. Many loyal men driven out of their homes. Hon. E. G. Barker attacked and badly wounded. Shot at on another occasion. The bullet and assassins held the county in terror.

"In Woodruff County a premium is offered for the murder of Union men. The $\mathrm{Ku}$ Klux riding about the county. D. P. Upham and F. A. McClure shot down while riding along the road. Several freedmen killed. Officers cannot execute the law.

"In Craighead County the rebels were preparing to fight. Captain Edwards shot down from the brush. Judge Carson's office destroyed by the Ku Klux, and he compelled to leave to save his life; dare not return to his family.

"Capt. Simpson Mason murdered in Fulton County and several others killed.

"In Conway County a court was broken up by a mob, county officers compelled to leave, many negroes killed and beaten; $\mathrm{Ku}$ Klux forces raised to oppose the law; State Guards forbidden to drill.

"In White County assault made upon Hon. S. Wheeler with intent to kill, by two desperadoes; several colored men killed; Jordan A. Ball, white Union man, and his nephew, both murdered; four other white Union men killed; Ban Humphries (colored) killed for knowing and reporting the leaders in the plot to murder Hon. S. Wheeler.

"In Drew County deputy sheriff and negro tied together and killed, a reign of terror inaugurated; men repeatedly threatened with death and many compelled to 
vote against their wishes. On the $\mathrm{I}$ 7th instant $\mathrm{Ku}$ Klux took a colored preacher who has not been heard of since.

"In these and other counties many other outrages and violations of the law have occurred. Men were driven from their homes; officers were forbidden to make arrests, and were compelled to abandon every effort to do so.

"The bullet of the assassin, threats, and every species of intimidation were made use of to prevent the execution of the law, and to rob the citizens of the rights and privileges of citizenship. A reign of terror was being inaugurated in our State which threatened to obliterate all the old landmarks of justice and freedom, and to bear us onward to anarchy and destruction.

"In the demoralization of a large class of citizens of the State, in the utter disregard to law and order manifested in many localities, it is perfectly clear that a prompt and decided course of action is necessary. The loyal people have adopted as a watchword the motto, 'Let us have peace'; and now that the election is over it is urged that the past be forgotten, and the hope is expressed that the murderer will cease his horrible trade, and that the violator of the law may possibly allow the law to be executed.

"But this merciful programme is neither in accordance with the demands of justice and right, nor a proper consideration of the welfare and prosperity of our State. The opposition to the law still continues. The rights of the citizens are still violated. It would need only another partisan excitement or great personal or social antagonism to develop again the full tide of wrong. There can be no permanent peace nor advancement in the future as a result of such a policy.

"The majesty of the law should be vindicated. The assassin should be visited with a just retribution for his crime. The violator of the public peace should be punished, and an officer of the law should be so protected 
and respected that no opposition whatever would be made hereafter to his executing the duties of his office.

"The commonwealth is composed of three parts,the citizen, the law, and the officers to execute the law. It is only when these parts work harmoniously that a healthy and vigorous constitution exists. If the officer fails in the discharge of his duty, he can be removed, and no detriment to the interests of the State or community arise. If the law is unjust in any of its features, by proper representation and process it can be repealed and no serious difficulty occur; but if the citizen becomes vicious and corrupt, and violates his obligations and duties, then indeed a deadly virus is introduced into the system which can only be cured by the most powerful remedies, but which must be cured, or ruin and death will ensue.

"Our whole system of government is based upon the rectitude, intelligence, and honesty of the citizen. Wherever these fail, wherever the citizen becomes thoroughly diseased politically, and all obedience to the law is given up, then our institutions become a failure and they will go out forever in darkness and gloom.

"In the diseased condition of the body politic in a portion of this State I had no alternative but to allow the infection to extend and increase until the whole should yield to its influence, or to proceed at once to the use of unusual and the most severe measures by proclaiming martial law in those localities where the strongest opposition to law and order prevailed.

"By the advice and co-operation of the leading Union men in the State I proceeded to take this step. I have done so calmly and deliberately and I shall endeavor to execute it with all the resources at my command and all the energy I possess."

The enumeration of conditions contained in my message was for the information of the Legislature, upon 
which it could base its approval or disapproval of my course, as the case might be.

While the facts contained in that message, upon which I then based my action, constituted all I had to report at that time, events were then happening which, if known, would have constituted very important additional reasons for my action. These events I shall now proceed to describe.

\section{ASSASSINATION OF DR. A. M. JOHNSON}

On the 24th day of August, I868, the day before Dr. Johnson was assassinated, he wrote a letter to me, from which I quote as follows:

"You will recollect the bitterness of feeling I represented to you that existed in this County. On the night of the I 8 th eight or nine men disguised (I can name them all) went to the houses of the colored men on James Edrington's place, shot one man through the lungs, and beat several others nearly to death; shot at several others. They attacked the negroes about one o'clock at night when they were all asleep. They are the same men that burned the colored church here in May. The colored men have no arms, and sleep in the woods with their families every night. Unless something is done we shall not get twenty-five votes. Our sheriff is as bad as the K. K. K. The Clerk and sheriff you appointed refused to serve, and we have no one I know of in the county that will act any better than the ones we have now. I stand picket on my life as regularly as the day and night come."

It was not until some time later that the Hon. James A. Butler handed me a letter from Dr. Johnson's wife, containing a graphic description of the horrible tragedy, from which I quote as follows: ${ }^{6}$ 


\section{"Keytesville, Chariton Co., Mo., "October I 2, I 868.}

"Hon. James A. Butler :

'Hon. Sir: After several weeks' delay your very kind and sympathizing letter came to hand; and I assure you I appreciate and thank you for the motive which prompted you to write to one who has been so bitterly tried!

"You ask for the particulars of that terrible night. You shall have them, if I have the power to write them. August 25 the Doctor arrived at Osceola, on his return from the Convention. We proceeded to get ready to start for the North that night (the packet landed at night on the up trips). He was in a hurry to get off, for he had promised Governor Clayton to go into the canvass of the State. We were waiting, but fearing the boat would not land, the Doctor and a colored man that was going with us started down to the landing to signal it; when they had proceeded about twenty yards I heard a gun fired and a cry. I felt that it was my husband, and with a light in my hand I started after him (the moon had gone under a cloud), and there in the road I found my dying husband! I sat down in the dust and took his dear head in my arms; he breathed one last, long, shuddering sigh and was at rest! O God! Such was the fate of one of the best, the noblest of men! Oh, could you have witnessed my anguish-have heard the frantic cries of my distracted children!"

MURDER OF ALBERT H. PARKER

About the last of March, r870, Maj. F. M. Chrisman, an ex-Confederate officer and the Circuit Superintendent of Public Instruction for the district in which the County of White was situated, conveyed to me the following information: That, a few days before, his official duties had called him to Searcy, White County. 
Court was in session and the small hotel was so crowded as to cause him to be assigned to a room and bed with a young man by the name of John McCauly. During the night he was awakened by the sobs and groans of McCauly. When he asked what was the matter McCauly replied that there was a great load on his conscience, a load that had prevented him from sleeping for nearly a week, and that he feared he would become insane unless he could in some way get relief.

Chrisman advised McCauly to confide his troubles in him, with the assurance that what he should tell would not be divulged to any one without his consent, whereupon the young man disclosed the circumstances of the murder of Albert H. Parker, perpetrated on or about October I4, I 868, by order of the Grand Cyclops of the Searcy Ku Klux den.

Chrisman told McCauly that I was a fair man and would treat him as leniently as possible, so he agreed that Chrisman might inform me of what he had told him and promised that he would not attempt to evade arrest. On receiving this information I took immediate action by sending Adj.-Gen. Keyes Danforth, with a detail of the Governor's Guard, to White County with orders to arrest and bring to Little Rock the persons named in McCauly's confession to Chrisman as having participated in the murder of Parker. I instructed Danforth to travel by night, and upon arrival in White County to place himself in communication with the Goad brothers, staunch ante-bellum Union men, and to obtain from them such information and assistance as would enable him to make the proper arrests; and then to proceed by night as rapidly as possible to a point south of the boundary line between the counties of Pulaski and White, as in all probability as soon as it was known that the arrests had been made the rescue of the prisoners 


\section{$7^{6}$

by Habeas Corpus proceedings, instituted in White County, would be attempted.

This proved to be a wise precaution, for after Danforth had crossed the line the sheriff of White County appeared with a posse, and attempted to serve such a writ upon him, -a writ which Danforth of course disregarded.

Adjutant-General Danforth was successful in arresting William L. Edwards, John G. Holland, and John McCauly, who, with William Brundidge and LeRoy Burrow, had actively participated in the murder of Parker. Brundidge had removed to Texas and Burrow was a traveling man, supposed to be absent in Memphis, but he was really on his way home to White County. The orders for the murder and the detail to carry it into execution were issued by Gen. Dandridge McRae and Col. Jacob Frolich, who was the editor of the Searcy Record and also the Cyclops of the Searcy Ku Klux Den.

Danforth reached Little Rock with his prisoners about midnight. I was at the county jail to receive $\mathrm{McCauly}$, and by arrangement with the authorities he was assigned to a separate cell, with instructions that there should be no communication between him and the other prisoners.

The incidents of the Parker murder, then told me by $\mathrm{McC}$ auly, were that night reduced to a sworn statement which, with all other papers necessary for the prosecution of the case, was handed to the Prosecuting Attorney, Gen. E. W. Gantt, to be used by him. When the cases were disposed of he returned to me certain papers, but this affidavit was not among them. However, the McCauly affidavit of June 2, I870, is of the same character and is confirmed by the affidavit of LeRoy Burrow. ${ }^{7}$ McCauly's affidavit is as follows: 
"John "June 2, I 870. "John McCauly, sworn, says that I have been residing at Searcy, White Co. I lived there from the first of September, I 868, until about last of December, I 868. When I was arrested in March, last, I was residing at Fairview in Independence County, Ark. My business has been clerking. I was clerking for Greer and Baucum in Searcy in fall of I 868 . I was initiated in April, I 868, at Searcy, into an organization known by outsiders as $\mathrm{Ku}$ Klux Klan and represented to me by three stars. I was living at Fairview in Independence County about 25 miles from Searcy. I went to Searcy and was asking Lee Burrow about such organization, telling him I did not believe there was any such organization. Lee Burrow said if I would stay until night he would show me that there was and would show me something that would make the hair rise on top of my head. At about I 2 o'clock same day I told Colonel Frolich I wanted to see the $\mathrm{Ku}$ Klux. He told me he would not show them to me until night, and I think asked me who told me about it. I told him Lee Burrow. I think Burrow told me Frolich knew about it-I met Lee Burrow that night and went with him to Colonel Frolich's office, the office of the White County Record, a newspaper edited by Colonel Frolich. I first had a preliminary oath administered to me by an unknown party-I am uncertain whether I was blindfolded at that time or not-I now think I must have been blindfolded before the first oath was administered. The oath was as follows:

"You do solemnly swear in presence of Almighty God that you will never reveal anything that you may know or hereafter learn of the so-called Ku Klux Klan.'

"The above is, I think, the exact words of the oath. It is the substance any way. I have administered the oath to others. I was acting as Adjutant-General for General McRae when I administered the oath, and organizing other dens in White, Jackson, and Independence 
Counties. After I took the above oath we were asked some questions, which were about as follows:

"Ist. Did you ever belong to the Federal Army?

"2nd. Are you in favor of white men ruling the Government? Answer to this question expected to be, 'Yes.'

"Those questions being answered satisfactorily, I was then ordered to kneel and take another oath; that oath was about as follows: We were sworn to obey all orders of all superior officers, that we would stand by and protect one another under all circumstances; to support only white men for office of profit or trust. After this oath was administered the blindfold was removed and I saw one man in the room with masque on. He was the one who had administered the oaths. Afterwards this man proved to be Colonel Frolich. He stepped outside the door and threw his masque off and came right back, and I knew his voice besides. I recognized in the room Lee Burrow, John P. Lewis, William Brundidge, William Sewell, and one or two others whose names I do not recollect. These men I did not see have masques on that night; I understood that to be the first den in the State and the organization recently commenced in the State. Frolich was then Head Cyclops, that answers to about rank of Captain in Army. The objects of the organization were explained by Frolich. He said it was a political organization of the old Confederate Army,military in its nature as well as political. At these meetings and at raids all were expected to be armed and ready for any emergency. He gave us to understand that if we could not have justice by law we would have to take the law in our hands. I think it was stated that this must be so even if men had to be killed to bring this about. I afterward learned that justice meant justice in accordance with their own interpretation of what was right; I understood at the time that the present State Government was not administered in accordance with what they thought it should be, and was an object of contempt, and 
should be resisted whenever it could be so done. The meeting was adjourned without considering other important matters. This was in April, I868.

"About the first of August following I came to Searcy. It was the morning after Capt. Stephen Wheeler had been wounded-Mr. Sewell first told me about it. After I got in town some one told me John P. Lewis shot him. That evening I think I went to General McRae's house. Colonel Frolich went with me. I had previously been acting as Adjutant-General to McRae. We talked over the matter with McRae; McRae seemed distressed about Lewis' connection with the affair. We had before learned that Wheeler was not killed. The distress seemed to be caused by the fact that it was not successful and at the probability of the authorities finding out the perpetrators of the deed-McRae said he had ordered this not to be done. He said Frolich or Sewell who had ordered Lewis to do it were in faultLewis is brother-in-law to McRae. Lewis told me afterward that he was ordered to do it by Sewell, who was Grand Maji of the Den, answering to Ist Lieutenant of Army, and that J. Floyd Smith, his cousin, persuaded him to do it. That he did not want to do it. I afterward heard that the order to kill Wheeler was first issued by General McRae, who afterward, when he found out who was to do it, countermanded the order. Lewis said he thought he had killed Wheeler. Lewis said they met Wheeler and Hicks in buggy, Lewis drew his pistol and Wheeler drew his and fired two shots at him. Lewis then fired one shot at him. When he fired at Wheeler, Wheeler threw his pistol on the ground and begged for his life; told Lewis to take his money but spare his life. Lewis said he would have both-Lewis ordered Wheeler out of the buggy and told Hill, who was with Lewis, to take charge of Wheeler. Hicks commenced to beg for his life; Lewis ordered him to drive his buggy out of the road and told him he did not want to hurt him, but if he did not hush he would kill him. Wheeler broke to 
run, Lewis ordered Hill to shoot him-Hill did not fire until Wheeler got 20 or 30 steps. Lewis told Hill to take charge of Hicks and he would kill Wheeler. He ran Wheeler some distance, shot at him twice, the third time he shot at Wheeler he fell. Lewis thought he had hit Wheeler in the back. As he was getting down to shoot Wheeler again, Hill came up to where he was. Lewis asked Hill where Hicks was: Hill said he was where he left him standing in road. Lewis told Hill to kill Wheeler and he would go after Hicks. He went to buggy. Hicks had cut the horse loose and left. He pursued him several miles; could not overtake him and came back-before he got back he met Hill. He threatened to kill Hill for letting Hicks get away-Hill begged for his life. They went back to where they left Wheeler and could not find him. I afterward heard Frolich, Sewell, and some others who I do not recollect speak of having Wheeler disposed of so he could not give in evidence, but don't know that any place was mentioned for this.

"On or about the I4th day of October, I868, LeRoy Burrow came to me after supper. He told me there was a man to be killed. I asked him who it was and what it was for. He said it was Captain Parker. He said Parker had got the secrets of the organization and had to be killed for self-protection, or to that effect. We got ready then. Mr. Burrow went off and returned again with Mr. Brundidge. We then came out of the store (Greer \& Baucum). Mr. Edward D. Holland and Brundidge went off, but were to meet us at the Springs. Burrow and Brundidge were the two officers and they directed myself; and Lee Burrow went on to the Sulphur Springs about 150 yards from Court Square. We then met Mr. Holland, Edwards, and Brundidge. We sat down on the steps near the springs. I suppose we waited ten or fifteen minutes before Mr. Russell and Albert H. Parker came. Mr. Russell was in advance, passing over the steps. As Parker came up he made some remark about the weather. As he walked over 
the steps Brundidge ordered Parker to hold on and make no noise or he would kill him, presenting his pistol at the same time. We all drew our pistols. It was starlight and Parker could see the party and their armsParker first tried to turn it off as though we were joking, we were searching him for arms and he treated it as a joke. We found no arms. We then tied a handkerchief in his mouth. I do not recollect which one did it. We marched him right off toward the McConnaha place, about one-half to three-quarters of a mile southwest from town. Before we got there we stopped and put on our masques. Took the handkerchief out of his mouth; then asked him if he had ever seen any Ku Klux and told him we were $\mathrm{Ku}$ Klux. He said he had been looking for them some time. He wanted to join them. I think Brundidge said that he supposed he had been looking for them from the contents of a letter that he had written Mr. Pugh at Little Rock. We did not have the letter with us that I know of; Parker denied having written such a letter. We went on to the McConnaha place, not much if anything was said on the way. Mr. Burrow and Brundidge told Parker he had but a short time to live, and if he had any confessions to make he had better be at it-Parker then acknowledged that he was then in the employ of the Governor as Detective. He said his reasons for being a spy were that he had killed a Federal Colonel in Texas and had come here and was arrested and through influence of friends he was released on condition that he would go to Searcy to ferret out the killing of Humphries. He pleaded for his life and told us if we would let him loose that he would leave the United States and we never would hear from him any more, or that he would go and kill Chrisman or any Radical in White County we would say, if we would spare his life. Brundidge told him if he were to kill every radical in the State it would not save him. He talked a great deal, telling about his past life, etc., I cannot recollect all. I suppose we were there an hour or more. At 
last Brundidge or Burrow, I can't now say which, told Parker he had but a short time to live; if he wanted to pray, to say his prayers. He said he had never prayed in his life, and asked some one of the party to pray for him. We all kneeled and Mr. John G. Holland prayed for him. He is a member of a Church-I think the Baptist Church-after prayer we all got up, and Parker continued praying audibly. He prayed some little time. After he got up he was ordered to kneel near the well. He did so, his face toward us. Brundidge I think gave the order to fire. All fired, Parker fell. Parker breathed afterwards. Brundidge ordered some one of the party to shoot him again. Burrow said he bursted three caps at his head. His pistol did not go off. The others said Edwards shot him afterwards about his head. I heard the shot but did not see it. We put him in the well and put some puncheons on the well. I believe Frolich knew he was killed before he published an Editorial on the subject to the effect that Parker had left the Hotel without paying his bill, and that he was a good Democrat and that the Loyal League had had something to do with disposing of him-Frolich and McRae both knew of this murder and justified the men who did it. I talked with them about it myself after it was done. There was a meeting of the Den after Parker was killed-some one remarked that some of the parties had better leave, as White County would certainly be put under Martial Law.

"William Brundidge, William L. Edwards, John G. Holland, LeRoy Burrow and myself were the party present at the killing of Albert H. Parker. I think James W. Russell brought Parker down by an understanding with the officer of our party. Russell came to the Springs with a bucket on his arm-I understood some one was to bring Parker to the Springs. Russell afterwards showed me Parker's letter to Pugh-it was the night we killed Parker. I was telling him what we had done to Parker. He showed me the letter and said he believed it was justifiable. I have seen, besides the names before men- 
tioned, in the Den, B. D. Turner \& Son, George Faucett, James Ridley, Henry Ridley, R. Paddy, John Moore, and many others. When there was any killing to be done it was to be talked over in the Den and referred to a sort of Court of five, called Yahoos, and if they could not decide, it was to be left with the Commanding Officer of the Den, or Post. If it was decided to kill, men were to be detailed to do it. The body of the order might not know who did it, unless they themselves told. There was a by-law that if any one killed any one without orders from Yahoos or proper officers, it was punishable with death, upon decision of the Yahoos. Or if any one failed to kill when ordered or to obey the orders of superior officers it was punishable with death-I think it was punishable with death to disobey orders. I don't think there was a commanding officer of the Dens for the whole State, but that there was a commanding officer for each Congressional District. I have heard General Fagan's name mentioned as being a member of the Den. I organized the Den at Batesville. There were present and became members Albert Cravens, Joe Merriweather, Robert Weaver, Charley McGuin, H. H. Dufin, and others whose names I do not remember. We were said to be 7,000 strong in this district. General Adams succeeded McRae. Adams lived in the eastern part of the State; did not know him; did not meet him. I think McRae was relieved on account of want of nerve, energy, and competency. I understood that General Forrest of Memphis was the Commander of the Dens throughout the South-Colonel Frolich and others told me Forrest was the highest officer of the Dens in the South. I was in one raid just before the election in White County - ten or fifteen were in the party. The party went out about two miles, had masques on, pistols, etc. I think Russell was in command of this raid. We went to Bob Jones', called Coburn's black people and old man Holt's-we frightened them and told them they must vote the Democratic ticket and use their influence 
for it or they would be killed. One raid was made to Ed. Robbin's. I was not along. William Sewell broke the door down with a rail, took pistols and guns from the negroes. Another time they went to Tom Bass, colored. They threatened him. They also made a raid on old man Guin, and gave him a note or left it for him and told him if he did not leave they would kill him. I heard about these things-was not present.

$$
\text { "(Signed) J. A. McCauly." }
$$

I have affidavits ${ }^{8}$ from a number of other wellknown members of the White County Ku Klux Klan which corroborate $\mathrm{McC}$ auly's affidavit, especially as to the murder of Parker and the attempted murder of State Senator Stephen Wheeler, but space prevents me from publishing them.

On April 7, I870, I received a telegram from the sheriff of Prairie County stating that a steamboat had just arrived at De Vall's Bluff with LeRoy Burrow as one of its passengers. I immediately ordered the sheriff to arrest him and bring him to Little Rock for custody. Late that night the sheriff reported with the prisoner at the jail where I was in waiting. I had him assigned to a separate cell, where he was not permitted to communicate with any of the other prisoners.

The first words I said to him were: "Burrow, do you know the cause of your arrest?" He replied, "I do not, but wish to." Holding McCauly's affidavit in my hands I said that I would read to him some White County history, and when I had finished he would know whether it was true or not. When I had read the last words I asked him what he had to say about it. He grew pale, drew a long sigh, and exclaimed: "That's just the way it occurred!"

I then turned him over to Judge Warwick, of the 
Pulaski Criminal Court, who obtained from him the affidavit heretofore referred to, which in the following extract in important particulars corroborates McCauly's affidavit:

"The first oath I took did not indicate the character of the order. I took that and afterwards Frolich administered the second oath to me, which was about as follows: I swore to forever oppose the Radical party-to that end we would work to place Democrats in power throughout the south. That we would obey all orders from superior officers; that we would assist and protect each other under any and all circumstances. The penalty for disobeying this oath was death.

"We were then instructed by Colonel Frolich that the order was said to be political in character, but was military in its organization; that it was not more nor less than the re-organization of the Confederate Army; the object was to carry the elections, and to overturn the radical government, and when we were sufficiently organized we would take the reins of government into our own hands.

"There was to be no name to the organization, but it was represented by three stars and known to the outside world as the Ku Klux Klan.

"We were thus enabled to swear, if it became necessary, that we did not belong to the Ku Klux Klan and to evade the law. . . . After awhile the order was used to intimidate radical voters by raids in masques, etc., and by threatening with violence."

The reader will naturally ask what finally became of the White County prisoners charged with these crimes. Sol F. Clark as attorney for the accused instituted unsuccessful Habeas Corpus proceedings in Little Rock and with the exception of McCauly and Burrow, who had turned State's evidence, the prisoners were refused bail 
and committed to jail, where they remained on account of various legal delays until January, I 87 I.

In the testimony given by Burrow it was disclosed that General Dandridge McRae and Colonel Jacob Frolich were the instigators of the murder of Parker. Immediately after this became known Colonel Frolich, who was the editor of the Searcy Record, sold his paper and both he and McRae became fugitives from justice. Frolich did not stop until he had crossed the line into Canada. Where McRae took refuge I have never known.

On April 22, I 870 , I charged them with being accessories to the murder of Parker and offered a reward of $\$ 500$ for each of them, but without success.

Some time during the winter of $1870-7$ I a political deal was made by the friends of McRae and Frolich with Joseph Brooks and his faction wherein the Democrats agreed not to nominate a State ticket for the election of I 872 , and that they would give their support to Brooks and his followers for state offices. They further agreed to combine with them for the nomination and election of a Liberal National ticket with Greeley and Brown as candidates. In return for this Democratic support Brooks and his faction were to find the means for acquitting the White County prisoners.

The Daily Republican of September I3, I87 I, spoke of this alliance in the following language: "A part of the agreement between the 'Brindletails' and the Democracy last winter was, as a matter of good faith, that the White County prisoners should be released and acquitted."

After a protracted absence, during which time the arrangement $I$ have spoken of was perfected, McRae and Frolich returned to the State and gave bond for their appearance in court. The other prisoners were immediately released on bail. 
As the time for the trial drew near the plan for their acquittal developed. John Whytock, who was judge of the circuit that included White County, was slated for the position of Chief Justice on their combined ticket. To make possible the election of a special judge to try these cases he went north under the pretext of visiting relatives. Sol F. Clark, who had been the former attorney for the principals in the Habeas Corpus proceedings, was selected to fill Judge Whytock's place. Immediately after his election the case was called for trial. The prosecuting attorney had allowed his witnesses to become scattered and none were present to testify. He moved for a continuance, but was overruled. Under these conditions the farcical trial resulted in a verdict of "not guilty."

So the ends of justice were defeated and another evidence given that the civil laws of the State could not be enforced against members of the $\mathrm{Ku}$ Klux organization.

The great mistake I made was in entrusting the trial of these murderers to the civil law. When the information of Parker's murder came to me I should have declared martial law in White County, and Jacob Frolich and Dandridge McRae should have been included in my order of arrest. Their trial would then have been conducted by a military commission and justice would have been meted out.

This, no doubt, would have precipitated war in the State, but I am convinced that open warfare would have been preferable to the stealthy methods of murder employed by the Ku Klux Klan.

It was a monstrous proposition that five men, called Yahoos, should have been vested with the power to seal the fate of an American citizen, and take the life of any man doomed by their decision, and then, by the very strength of the organization on whose behalf they acted, escape the consequences of their awful crimes. 
I do not suppose that history anywhere records such. conditions as were entailed by this self-instituted organization, which was composed of men who had never surrendered to the United States Government.

\section{CHARGING KU KLUX CRIMES TO REPUBLICANS}

The attempt to shift the burden of guilt from our own shoulders to those of absolutely innocent persons is the most despicable trait of human depravity. Yet I shall now proceed to give evidences of a well settled plan of the Democratic party in Arkansas to shift $\mathrm{Ku}$ Klux outrages upon Republicans, and often upon ignorant and innocent negroes.

\section{THE ASSASSINATION OF BAN HUMPHRIES}

In the affidavit of LeRoy Burrow, heretofore referred to and abundantly substantiated, the following language appears:

"I was gone when Ban Humphries was assassinated. Brundidge told me, however, that he in company with James W. Russell and Howell Bradley, under orders from Superior officers-did not say what officers-killed Ban Humphries. It was generally understood by the Den that Humphries was killed because he was a leading and influential radical colored man in the county. Brundidge told me he shot Humphries."

This crime was committed about midnight on August 28, I868. On September I, I 868, the following letter appeared in the columns of the Gazette:

"Searcy, August 29, is68.

"Editors Gazette: About midnight last night a horrible murder was committed in our town. A negro named 
Ban Humphries was taken from his house and shot through the head. The citizens in the neighborhood were aroused and went to the place immediately, but no clue to the perpetrators of the act could be had. The negro lived about an hour, but was unconscious.

"The citizens have called a meeting for 2 o'clock today to take steps to put a stop to acts of this kind.

"There is no suspicion resting upon any one particularly, but it is believed that Radical Loyal Leaguers, negroes or whites, did the dark deed. The community arrives at this conclusion from the following facts and circumstances:

"Ban was in 1861, '62, and '63 in the Confederate Army as a servant. He was a very zealous rebel and used to boast of the many battles and skirmishes he was engaged in. After the war it was generally believed he was acting with the radical party and was a member of the Loyal League; but he took no active part and was generally very quiet. A short time since, he, with many other negroes in the county, caused notices to be circulated that they would meet to-night (August 29) in Searcy to organize a colored Seymour and Blair Club, of which it was reported he would be an active member. These facts drive to the conclusion that he was put away by members of his league to prevent the betrayal of their plans, which they feared.

"The citizens are desperately indignant, and I believe if the perpetrator could be found it would be impossible to prevent his execution by a mob. The Democratic negroes are so terrified that it is not believed that they will venture to form their club. This is a part of their programme. How long are these things to continue?"

THE ATTEMPTED ASSASSINATION OF CAPT. E. G. BARKER

On September 5, 1868, about a week after the attempt upon the life of Captain Barker, so graphically described by Col. E. M. Main on pages 135-136, an 
editorial was published by the Gazette, from which I quote as follows:

"... It is intimated by a Memphis contemporary that the less the radical press says about the assassination of one of these public functionaries, the better. A gross interference with the social affairs of a peaceable colored family is hinted at. . . The cause that led to the sound drubbing given to another member, and the shooting of Barker through the window, are unknown to us. We hope to learn in the course of time, and when we do we shall give the public the benefit of the facts, whatever they may be. We feel justified, however, in saying that this man Barker had the quality of making himself hated in such a degree that it is the second time he has been shot by some unknown person,- - once in Ashley, southeastern county, and lately in Crittenden County, in the northeast. He is the same person who was suspected as a confederate in the robbery of the government of its revenue at DeVall's Bluff a year or two since. . . ."

\section{THE ASSASSINATION OF CAPT. SIMPSON MASON}

The following extract is from the Batesville Times, -an extract that appeared in the Gazette, October I, I 868 ,- -both Democratic papers:

“.. Mason was a man of bad character, and was accused of several murders. He was probably killed by parties who entertained feelings of revenge for some of his past acts, and who took advantage of the unsettled condition of affairs to kill him, hoping that it might be attributed to political animosity, and thus shield themselves. He was president of the board of registration in Fulton County, and we have no doubt the radical press and party will attribute his death to political causes, and endeavor to make political capital out of the matter." 
From the Batesville Republican:

"The deceased (Mason) always possessed the unbounded confidence of the State and national authorities, and at the time of his death filled three positions of trust: agent of the freedmen's bureau; president of the board of registration of Fulton County, and captain of a company of State Guards."

The following extract is from an editorial entitled "War in North Arkansas" that was published in the Gazette, October 6, I 868 :

“... Mason was likewise a desperado. Long after the war closed he remained in the field to rob, steal, and destroy. As late as ' 67 information was sent by responsible gentlemen to the civil and military authorities in this city relative to his unwarrantable conduct, and asking for protection. Full particulars of affairs in that section have not yet been received, but the rumor is prevalent that Captain Bryant was instrumental in causing the death of Mason, and for the very best of reasons."

ASSASSINATION OF GEN. T. C. HINDMAN

On the $27^{\text {th }}$ day of September, I 868 , about 8 P. M., General Hindman was shot through a window of his home at Helena, Arkansas, and killed. In reference to this murder I insert the following extract from the $\mathrm{Mem}$ phis Appeal, which was published by the Gazette on October 4, I 868 :

"... From information that we have received otherwise, there is not the shadow of doubt but that the deed was the work of the hellish Loyal League. General Hindman has been, since the close of the War, an ardent supporter of the democratic cause, and a bitter foe and 
denouncer of radicals and radicalism. They have now, no doubt, wreaked the vengeance that they have so often sworn, and in a true radical manner, - by the hand of an assassin. More blood smokes upon the altar of our desolated south and cries aloud for vengeance."

From the Daily Gazette, November 21, I868, copied from the Memphis Avalanche, November 3:

\section{"STARTLING REVELATIONS \\ "ASSASSINATION OF GENERAL HINDMAN PLANNED BY RADICALS}

"... The past few days have produced revelations which firmly fix the crime of this horrid murder upon not an individual member of the radical party in Arkansas, but upon the leaders of that foul organization themselves. The efforts of detectives have developed, beyond possibility of doubt, that the assassination of General Hindman was planned in Little Rock by leading radicals and executed by their orders. ..."

From an editorial, "General Topics," published in the Gazette, March 23, 1869:

"Tuesday, the 16 th, in the jail at Helena a negro confined therein boasted that he 'killed Tom Hindman.' This was made known by the prisoners and he was taken out and sworn. He stated that Porter (another of the negro prisoners) killed him but he had a part in the murder, and that it was a part of a plan that had been concocted for revenging the lynching of a negro ravisher and murderer shortly before that. The plan as it had been agreed upon was to murder certain citizens and burn Helena. Charles Porter was assigned the part of killing General Hindman and others to several similar atrocities. Porter carried out the arrangement on his part. Thus a gifted and illustrious man, in the midst 


\section{CIVIL WAR, IN ARKANSAS}

of his family, ardent with the hopes of the future, fell by the hand of an unknown assassin whom he had never injured but proposed to benefit. The negro who wounded Sheriff Turner so terribly was one of the original gang, but owing to the attempt to arrest him, had to show his hand prematurely. This act having placed the citizens in a state of preparation for similar outrages alone prevented the consummation of the diabolical scheme. But its principal object was accomplished,the assassination of Hindman. Wonder if there are not those in Little Rock, not of the Ku Klux Klan, who could tell why it was that the murder of Hindman must be accomplished, notwithstanding the rest of the scheme should fail? Porter and eight other negroes have been arrested."

\section{From the Gazette, March 25, I869:}

"The Helena Monitor of the 2oth says: 'In the recorder's court on the occasion of the examination of Grant, as witness in the Hindman assassination case, the prisoner, Charles Porter, alleged by Grant to have committed the deed, was placed in a crowd of other negroes and the witness asked to identify the accused, which he failed to do, stating that the Porter he meant was not in the crowd. Porter was thereupon promptly discharged. He was an honest-looking negro, of middle age. The witness is a mere boy and doesn't seem to know what he is talking about. He still insists upon his charge against Charles Porter, and is held in custody, awaiting further developments. Perhaps his man may yet be found.'"

Up to this occurrence the roll of assassinations, during the period I am describing, contained the name of no prominent Democrat, and the opportunity to charge this murder to the Republicans was received by the Democrats with much satisfaction. 
I watched the case with great interest, and on October 23 , I 868 , I offered a reward of $\$ 1,000$ for the apprehension and conviction of the murderer or murderers. The question may be asked, "Why was this reward delayed so long?" My answer is that I did not wish to offer inducements for the conviction of innocent people, and I awaited the results of the judicial investigation of the charges against the eight negroes, which I believed to be a mere pretext to sacrifice upon the altar of justice an innocent and helpless victim, and thus quiet further investigations.

I was informed by the Prosecuting Attorney that all the efforts to shift the responsibility for this crime upon the Republicans were mere inventions, instigated, as was believed by many, by Mrs. Hindman's brother, the author of the following card that was published in the Gazette, December I, I 868 :

"A CARD FROM GENERAL HINDMAN's BROTHER-IN-LAW
"HELENA, ARK., November I I, I 868.

"Editors Commercial: In the telegraphic columns of your paper dated the 6th of November appeared a St. Louis dispatch of November .5, stating that a son of the late General Hindman was in the city (St. Louis), and that the general was assassinated by his brother-inlaw just after he (Hindman) had filed a petition for divorce from his wife.

"Your dispatch contains two demonstrable lies; the first, in respect to the deceased's son arriving in St. Louis. $\mathrm{He}$ left but two sons, the oldest but eight years of age, and both are now with their mother in this place. The second; as to his having filed a petition of divorce, which is false, as the records of the court here will show. The third statement in the dispatch charges his assassination upon his brother-in-law, and refers, as I take it, to me, in consequence of certain rumors put 
afloat by lying radical conspirators in this State, to cover their own guilt. I now denounce the authors of the report connecting my name with the murder of my brother-in-law, Gen. T. C. Hindman, as liars and slanderers, and I demand of you, as a matter of right, to furnish me the name of the author of the dispatch alluded to or the reliable authority spoken of, and ask you as a matter of justice to insert this card in your columns.

\section{"Respectfully, \\ "Cameron N. Biscoe."}

A few years ago I was informed by Judge Stephenson, a prominent citizen of Helena, that a petition for a divorce from his wife, the sister of C. N. Biscoe, had been drawn up for Hindman by Judge Horner, Hindman's attorney, and placed in his safe to be filed the next day, which of course Hindman's assassination that night prevented. Judge Stephenson said that among the prominent citizens of Helena this fact was generally known. It is to be observed that Mr. Biscoe, author of the above card, does not deny the existence of the petition, but merely alleges that it had not been filed.

General Hindman, at the close of the Civil War, sought refuge in the Republic of Mexico. Upon his return in 1866 he settled in Helena, Ark. As late as May 28, I 867, he did not hesitate to attend a mass meeting at Helena, which was largely attended by Republicans, white and black, and which was presided over by Dr. Thomas Smith, a Republican, and afterward Superintendent of Public Instruction under my administration.

To show the views Hindman entertained on the questions of reconstruction and political partisanship, I insert the following extract from the Gazette of June I I, I 867 , reporting the proceedings of said meeting: 
“. . Pending the report of the committee on resolutions, Gen. T. C. Hindman, being called for, addressed the meeting, advising the citizens of the county, not disfranchised by the acts of congress, to register and enter sincerely and honestly into the work of reconstructing the state under the law which disfranchised himself and men of his class, - not because he believed that a better might not have been framed, but because it is the best we can get. $\mathrm{He}$ is willing to plant himself on the congressional plan fairly, squarely, and honestly-but opposes confiscation-favors the devotion of all our energies to the building up and repairing the losses of our country, rather than engaging in a political crusade; no good man but desires the prosperity of the people among whom his lot is cast recommends a united vote, without party contest. . . ."

At no time during General Hindman's career in Arkansas was he considered a "violent" partisan, and up to the date of his assassination to the best of my knowledge he held no political position and took no prominent part in organizing the Democratic Party. He was inclined to be independent in his views, and he did not always fall in with the programme of the Democratic leaders. I know of no citizen of Helena, Ark., or indeed of the whole State, except perhaps Mr. Biscoe, who now maintains that Hindman's assassination was of a political character.

\section{ASSASSINATION OF CONGRESSMAN JAMES HINDS}

The assassination of Congressman James Hinds, and the attempted assassination and wounding of State Representative Joseph Brooks, occurred in Monroe County, October 22, i 868 , while they were going to a Republican meeting to be held six miles from Indian Bay, where 
they had been previously billed to speak. While they were traversing a thickly wooded part of the road George W. Clark, a citizen of Monroe County, appeared on the highway, mounted and armed with a double-barrelled shot-gun. He immediately shot Hinds, killing him almost instantly, and with the other barrel wounded Brooks.

On the following day, the $23 \mathrm{~d}$, the news of this occurrence came to me through a telegram from the sheriff of Monroe County, which read as follows: ${ }^{9}$

$$
\text { "INDian Bay, Ark., Oct. 22, I 868, }
$$

"Governor Clayton: Brooks and Hinds were shot at 2 o'clock P. M. to-day, from the brush. Hinds lived two hours; Brooks slightly wounded. Send metallic coffin per Steamer Liberty, Saturday. Mrs. Hinds' address, East Greenwich, Washington County, New York.

"Frederick P. Wilson, "Sheriff Monroe County."

Two days after the assassination, on October 24, I868, the following editorial appeared in the Gazette:

"Information reached this city on yesterday of the murder of James Hinds and the wounding of Brooks, of Helena, near Indian Bay, in Monroe County. If true at all, we believe that the deed was perpetrated by the radicals themselves for effect on the presidential election north. That party is resting under a heavy onus. They plan and execute the majority of the outrages perpetrated in the State for the purpose referred to. The false reports constantly sent abroad, and the utter failure of the authorities to bring any one to justice would seem to corroborate this view. The announcement by the northern press that a 'late loyal member of congress had been 
assassinated while peaceably riding along the road' would undoubtedly have its effect among those not better informed. Another strong motive for removing one or both of these men who are the favorites among the radical negroes would be the securing of their position of influence with this strong political element by some competitor, and the excitement that would be produced on the minds of the ignorant members of the Loyal League. At all events the only class that could possibly reap any benefit from such a deed would be the Clayton Government in Arkansas, and the radical party north, while it could only prove hurtful to the interests of democracy at home and abroad if either instigated or winked at by them. It is not to the interest of any democrat or prominent citizen of Arkansas to harm a single hair of any man's head. We deplore the occurrence, which appears to be true.

"It will be remembered that Hinds' congressional district was gerrymandered by his own party in the last legislature for the express purpose of throwing the county in which he resided (Pulaski) into a white district, thus overslawing him. Brooks was a prominent candidate for the United States Senate against B. F. Rice, the successful candidate. Hinds possessed great popularity with the negroes, and Brooks is undoubtedly the ablest man of his party in the State, though not popular with it. We are satisfied that the deeds were perpetrated at the instigation of the radical leaders to get rid of troublesome competition in the party and for political capital north. No possible benefit would have inured to the democratic party from the murder of these two men, as they had both been shelved, politically, by their own party. For this reason they were discontented and were making a canvass for no other purpose than to array the mass of the negro population against the central managers, Rice \& Company. They were capable of doing them great injury. Hinds, just before his departure, had gone openly about the streets of Little Rock, asking to be told how 
he could get into the $\mathrm{Ku}$ Klux organization. $\mathrm{He}$ said he understood the organization was instituted for killing off the scoundrels of the radical party; that he knew numbers of them who deserved killing and wanted to join the $\mathrm{Ku}$ Klux to aid in the extermination of Rice \& Company. Brooks was equally indignant but entertained deeper resolves in silence."

On the day previous to the murder, doubtless in anticipation of what was to follow the next day, a "Peace Meeting" was held at Indian Bay in Monroe County. George W. Clark was made secretary of this meeting, and he was also secretary of the Monroe Democratic Central Committee. "Peace Meetings" were often the precursors to $\mathrm{Ku}$ Klux outrages!

The day after the murder the coroner's jury, composed of members of both political parties, rendered a verdict of which the following is a copy: ${ }^{10}$

"The said James Hinds came to his death by wounds inflicted on him by shot discharged from a double-barrelled shot gun, in the hands of George W. Clark."

\section{ASSASSINATION OF MAJOR ANDREWS, LIEUTENANT} WILLIS, AND AN UNKNOWN COLORED MAN

The Republican in its issue of November 2, I868, published the following extract from a private letter relating the circumstances in connection with the murder of Major Andrews, Lieutenant Willis, and an unknown colored man:

"Judge Searle, Jake Townsend, and McWhorter came in here last night with the sad intelligence that Major Andrews and Lieutenant Willis had been assassinated by Baker and his damnable Ku Klux gang. Andrews, Willis, and the sheriff were going to Andrews' 
plantation and were bushwhacked by these cowardly villains at the crossing of Walnut Bayou. Sheriff wounded. Baker's gang had a plot laid to murder Searle, Townsend, and McWhorter, but they got wind of the affair, took another road and came here. This morning Townsend, Searle, Casey, McWhorter, Taninon, and myself started for Rocky Comfort to collect facts in the case, etc., but learned that Baker had about one hundred men, and was looking for us. Two of Baker's gang followed Searle and party to this place, and left to-day at II A. M."

In this connection I quote as follows from the official report of Col. J. E. Tourtelotte, ${ }^{11}$ of the United States Army, who was sent by the General in command of the District of Arkansas to investigate conditions in southwest Arkansas:

"I found that P. J. Andrews, H. F. Willis, and one negro, name unknown, had been murdered. A coroner had held an inquest over the bodies of Andrews and Willis, but no inquest was held over the body of the negro. At the time of my arrival the said coroner was absent in Van Buren; the only witness (Mr. Standal) before the coroner was absent, said to be in Little Rock, and the papers showing the proceedings before the coroner could not be found, but it is supposed they were in the possession of the coroner at Van Buren.

"From witnesses, however, not sworn before the coroner, and from the statements of persons who conversed with Mr. Standal, I am able to make the following statement :

"Between 8 and 9 o'clock of the 24th ultimo (October) Mr. Standal, sheriff of Little River County, was a few miles from Rocky Comfort in company with P. J. Andrews, Assistant United States Assessor, and H. F. Willis, agent of the bureau of A. F. \& A. L.

"Mr. Standal was on horseback and a little in ad- 
vance of the others, who were riding in a light buggy, drawn by two horses, one belonging to $\mathrm{Mr}$. Andrews and the other belonging to Mr. Willis. The said persons were proceeding toward Rocky Comfort when a party of men, supposed to be seven in number, stepped from the bushes by the roadside and ordered Mr. Standal to halt, dismount, and give up his pistol. All this $\mathrm{Mr}$. Standal did. One of assaulting party then was left to watch Mr. Standal while the others ordered Messrs. Andrews and Willis, who at that time came up, to halt and deliver their weapons. Some altercation ensued when the said party fired upon Messrs. Andrews and Willis, and Mr. Standal started to run. Two shots, one tearing his coat and the other his hat, were fired after $\mathrm{Mr}$. Standal, who succeeded in escaping.

"About 2 o'clock P. M. of the same day Captain Hazeldine, of the State militia, who was drilling a company of negroes at Rocky Comfort, receiving notice of an assault upon Messrs. Andrews, Willis, and Standal, immediately marched to the scene of the murder and found said Messrs. Andrews and Willis and a negro (name unknown) dead.

"About 3 o'clock on the same day five men, mounted and leading three horses belonging to Messrs. Andrews, Willis, and Standal, came up to a young man named McCreary who was herding horses in Red River bottom and asked him if he sold horses to Scott's militia. He answered that he did sell horses to them, and to any others who wished to purchase. They then arrested the said McCreary and threatened to hang him. A negro then came up to the party, one of whom fired upon him, wounding him severely. The said party of mounted men proceeded to Elliott's Ferry, on Red River, which they crossed to the south side, first releasing McCreary and ordering him to go home.

"On the evening of October 26, r868, a citizen of Little River County met, about three miles from Richmond, Ark., eight horsemen, one of whom was mounted 
on the horse belonging to Mr. Standal. Once, at least, since the murder of Mr. Andrews has his horse been ridden through the town of Richmond. The persons riding and having in possession the horses of Messrs. Andrews and Standal were strangers and cannot be identified by the citizens and old residents who saw them. . . ."

The assassination of Willis and Andrews was actuated by a double motive: first, the unpopularity of officers of the Freedmen's Bureau, whose duty it was to protect the newly emancipated negro in his labor contracts, a disposition having been manifested by many of the slave-holders to defraud him in the settlement of his accounts; second, the desire to possess themselves of the horses and other property of the murdered men. These reasons were stimulated by the political unpopularity of the victims, both of whom were prominent Republicans.

As a matter that may be of interest to my reader, I here insert a description of an incident that occurred during the prevalence of the $\mathrm{Ku}$ Klux Operations in Arkansas.

I would first say that I was not at that time unaware of the intense hatred I had aroused by my determination to suppress, so far as lay in my power, the lawlessness and outrages in the State. The men who were daily committing these deeds of violence asked nothing but the chance to remove me from their path, but I did not deem it expedient to maintain more than an ordinary watchfulness. Assassins are cowards, and I am convinced that it was my treatment of them as such that preserved my life, not only during the days of the $\mathrm{Ku}$ Klux, but also in later years when political animosities have been extreme.

One night, having been detained at the Executive 
Office by urgent official business, about midnight I left on foot for my home. As I emerged from the front door of the Capitol I noticed on the opposite side of Main Street a man watching the entrance referred to. When he saw me he turned suddenly away and disappeared in one of the side streets. As I passed down Markham Street, feeling very much fatigued, I went into the saloon of Hornerbrook and Townsend to get a stimulant. While I was there I saw on the opposite side of the room three young men with their heads close together. Their glances in my direction indicated that I was the subject of their conversation. I immediately left.

It was a beautiful night with a full moon casting her lights and shadows everywhere. As the side alleys entered at right-angles to the street I was traversing, the dark shadows-where the alley terminated with a house on the south side-made it very easy for a person lurking there to spring out and perpetrate an act of violence upon anyone passing along the sidewalk. As a precautionary measure, I took the middle of the street, and I had not proceeded far when I heard the patter of feet behind me. Looking back, I saw three men running rapidly toward me.

I happened just then to be at a point where two streets intersected. The lot on the southeast corner was enclosed on the street side with a high plank fence which cast a dark shadow on the sidewalk. I had only time to place my back against this fence, where I was concealed by its shadow, cock my revolver, and await events. Very soon the men came up and halted. One remarked, "It was here I saw him last." Another said that I had perhaps turned the corner and taken another street, equally direct, to my residence. The third man suggested that they continue their chase at full speed 
in the direction they were going, so as to arrive at my house before I reached it. They immediately acted on his suggestion; whereupon I took the opposite direction to police headquarters, from whence, with a sufficient escort, I went to my home and found the servants in great turmoil. They said that about two hours before a horseman had posted himself on the opposite side of the street, and that his attention was directed toward my house. They also said that a short time before my arrival three men had come running to the house, and after they had consulted with the horseman he had fired three shots from his revolver, whereupon they had all scattered.

The firing of the pistol by the horseman was evidently a signal to others engaged in the plot, stationed elsewhere in the city, to disperse. It was evident that they were pursuing me. What their ultimate purpose was is a matter of conjecture.

After this incident I made no more nightly passages to and from my house without a sufficient escort.

In closing the description of the Ku Klux outrages, I will here state that there were no successful efforts made by the civil authorities to arrest, much less to prosecute, the perpetrators of the crimes referred to. This may be explained, first, by the fact that the Ku Klux terrorized the officers whose duty it was to execute the laws; second, by the ease with which one or more members of the $\mathrm{Ku}$ Klux organization could get themselves summoned to serve on the juries; third, by the inactivity of officers who were either inefficient or who themselves belonged to the organization.

It proved to be absolutely impossible for the State authorities, in the face of the ingenious Ku Klux means to block their operations, to bring any member of the Klan to justice through ordinary criminal proceedings, 
no matter what the crime might be with which he was charged. Under these conditions, the reader will understand how the growth of political crime would be immensely stimulated.

I will here add that space will not permit an enumeration and description of the hundreds of negroes who were killed and otherwise outraged by the unrestrained $\mathrm{Ku}$ Klux nightriders.

The question resolved itself into a plain proposition: Should the $\mathrm{Ku}$ Klux organization rule Arkansas, or should its members be made subservient to the laws of the State? Of course the Ku Klux set up no claim to Constitutional authority; but declaring that the Government of Arkansas was "unconstitutional, null, and void," and that no man was bound to respect it, the Klan assumed powers that plunged at least thirteen counties of the State into conditions of anarchy. As a last resort the declaration of Martial Law and the suspension of the Writ of Habeas Corpus became inevitable.

\section{FOOTNOTES FOR CHAPTER V}

${ }^{1}$ See McCauly's affidavit, pp. 79-80.

${ }^{2}$ See pp. 88-89.

${ }^{3}$ Daily Republican, November 6, 1868.

${ }^{4}$ Daily Republican, November 1 7, 1868.

${ }^{5}$ Arkansas House Journal, I868-69, pp. I5-19.

${ }^{6}$ Daily Republican, October 30, 1868.

${ }^{\top}$ See p. 85.

${ }^{8}$ James M. Ridley, Anthony K. Gibbons, James M. Brundidge, William N. Slack, James McCauly, Columbus Nichols, and Robert P. Weaver.

${ }^{9}$ Daily Republican, October 24, 1868.

${ }^{10}$ Daily Republican, October 29, 1868.

${ }^{11}$ Arkansas Gazette, December 2, 1868. 


\section{CHAPTER VI}

MARTIAL LAW AND OPERATIONS THEREUNDER OF STATE MILITIA

As it was impossible during President Johnson's administration to procure arms from the General Government without an act of Congress authorizing that measure, a bill was introduced for that purpose. However, having grave doubts of its passage before the adjournment of Congress, I sent Dr. J. M. Lewis to open negotiations with some of the Governors of the loyal States, -Illinois being the first,-for the purpose of borrowing arms under proper security for their return. The Doctor's mission failed, and the bill in Congress having made no encouraging progress, I arranged with Messrs. Hodges and Weeks for the advancement of funds, and for the purchase of 4,000 stands of arms with corresponding ammunition and equipment. The results of this effort are described in my message to the General Assembly, November 24, I868, from which I quote as follows: ${ }^{1}$

"In carrying into effect the militia law obstacles have presented themselves, chief among. which has been the inability of the Executive to provide arms and equipment. When your body adjourned we had every assurance that the Government of the United States would supply this deficiency, but the act that was pending before Congress at that time failed to become a law, and that body adjourned without making any provision for 
the defense of the State. It became apparent that, in order to enforce the law and give protection to the people, some other steps must be at once taken by which arms could be obtained. No appropriation having been made by your body for the purchase of arms, and the necessity being imperative, I proceeded, by the authority vested in me as commander-in-chief, to open negotiations with persons in this city for the use of private funds for their purchase, expecting that your honorable body would sanction what I might do in that direction. These negotiations led to an arrangement with Messrs. Hodges and Weeks, who agreed to furnish the necessary funds, with the understanding that I and others should become personally responsible in case the Legislature should fail to reimburse them. I appointed $\mathrm{Mr}$. Hodges agent of the State, with directions to proceed North and make purchase of arms on the best terms he could secure. . . . He purchased 4,000 stands of arms which were shipped to Little Rock, but were stopped at Memphis by a combination on the part of the transportation companies.

"On the I2th of October I chartered the Steamer Hesper, commanded by Capt. S. Houston, and directed him to proceed to Memphis and transport the arms to this place. Captain Houston left here on the 12 th and left Memphis with the arms on the 15 th of October. When he was about twenty miles below that city an armed band of men, disguised, on the steam-tug Nettie Jones boarded the Hesper and destroyed and carried away the arms belonging to the State.

"This piratical party was fitted out at Memphis, and as the offense was committed upon the waters of the United States, over which the State has no jurisdiction, you are respectfully recommended to memorialize the Congress of the United States for the amount expended for the property of this State that was destroyed.

"The loss of these arms and the inability of the Executive to procure others rendered it impossible for 
me to give such protection to the peaceable and lawabiding citizens of our State as the insurrectionary condition of affairs demanded.

"I earnestly recommend that Legislative action be had authorizing the purchase of arms, and also to make appropriation for the expense of the militia. I have been very much gratified with the prompt response by the militia to my call for troops, and I am assured that many who are willing to assist cannot do so for want of arms."

This failure induced me to appeal as a last resort to General Schofield, then Secretary of War, for the use of the Government arms that were at that time lying idle in the United States arsenal in Little Rock. An account of this appeal is given in the following extract from the "Diary of Gideon Welles," then Secretary of the Navy, Vol. III, p. 460:

"Friday. At the Cabinet meeting, Gen. John M. Schofield, Secretary of War, read a letter from the Governor of Arkansas, expressing great apprehension of trouble from the people who are armed, and requesting that he might have the United States arms that were in the arsenal to put in the hands of the militia. . . General Schofield was very earnest in this matter; said the opponents of the Governor were Rebels who retained their arms when Kirby Smith surrendered; that loyal men would be overpowered and killed by the Ku Klux."

However, my request was refused and I entered upon the execution of my Proclamation of Martial Law without a gun or round of ammunition, without a single tent, wagon, horse, mule, or equipment, and without food or raiment with which to feed and clothe the men. Through lack of legislative appropriation, there was not a dollar 
in the Treasury available at the time for the expenses necessary to carry into effect the proclamation.

The difficulties of this situation were greatly increased by the irregular manner in which the Arkansas Confederate soldiers had been permitted to break up and return to their homes at the close of the war. This will be made plain to the reader by the following extract from the report ${ }^{2}$ of Gen. J. J. Reynolds to the War Department, dated May 27, I865:

".... The few soldiers left in Arkansas were deserting every day, and would all do so if let alone for a short time .... E. Kirby Smith directed a sale of the public Confederate property that could not be conveniently moved into Texas, but the Arkansas Confederate soldiers declared that as they had not been paid for a year and a half or two years, and had nothing to work with, they would take what they could in settlement of account and go home with it. In this manner the most of their transportation and animals are disappearing, and the men are going home with their arms.'

From the foregoing extract it will be observed that a large number, doubtless a majority, of the Arkansas Confederate soldiers were permitted to desert and return to their homes without surrendering to the United States Government, and to carry with them such property as they saw fit to lay hands upon, including arms and ammunition, and, what was still worse, to create the secret organization known as the Ku Klux Klan. Even those who regularly surrendered in Texas, serving under Kirby Smith, were permitted by the terms of surrender $^{3}$ to retain their horses for the alleged reason that they would need them for the cultivation of their crops. These liberal terms of surrender certainly were not granted in order to furnish the means for the mid- 
night $\mathrm{Ku}$ Klux raiders to ride over the country terrorizing peaceable people and stealing their movable property, as was frequently done.

The I0,000 Arkansas Union soldiers when mustered out were required to turn in their arms and equipment, ${ }^{4}$ and even the loyal militia organizations under the Murphy Government were required to disband and turn in their arms to the Federal Government; while every effort made by me to arm the State militia was unavailing. Thus the loyal Union men who entered the Federal Army were left to the tender mercies of the very men who in many instances during the first year of the war as Confederate Conscription officers were charged with running them down with bloodhounds, carrying them in irons to the nearest Confederate Post and compelling them to serve against the Government they had been taught to regard with the greatest affection and loyalty.

What a travesty upon the paternal obligations of the now victorious Government to assist in the maintenance of an equal and coördinate State Government created by it, and to throw its shield of protection over the returning Arkansas Union soldiers who, under unprecedented hardships, responded to their country's call in the hour of its direst need!

Seldom perhaps in American history has a military movement been organized and successfully prosecuted under such tremendous difficulties. After my proclamation of martial law I passed some very anxious days and nights, as it was far from certain that the militia, in the face of such a situation, would respond to my call. This anxiety, however, was changed to gratification and sentiments of the highest appreciation of their loyalty when I learned from various sources that the militiamen were flocking, principally from the mountain regions, to the 
places of rendezvous designated by their district commanders. They were in most cases mounted upon their own horses and armed with weapons of their own, or such as they could borrow from their neighbors.

General Catterson, who was a Brigadier-General of volunteers in the Civil War, with an excellent record, proved to be fully equal to the task assigned him. This tribute of approval applies equally to Major Demby, who was an invaluable support to General Catterson. As a mark of my appreciation of his services I promoted him from the rank of major to that of colonel.

Within nine days from the date of the Proclamation of Martial Law, General Catterson and his staff arrived at Murfreesboro, Ark., the place of rendezvous for the troops under his command. Notwithstanding the remarkable activity of General Catterson and Major Demby in organizing and assembling their commands at Murfreesboro, the enemy, with their perfect $\mathrm{Ku}$ Klux organization, had already assembled 200 men at Centre Point, then in Sevier County, and had on the line of march for that place the following bodies, ${ }^{5}$ - 150 men under the notorious Baker, one company from the southern part of Pope County, two companies from Little River County, I6o men from the northwestern part of Hempstead County.

General Catterson has recently died, but Colonel Demby is still living at Hot Springs, Ark. Some years ago I obtained from Colonel Demby the following facts concerning the encounter at Centre Point, which were later submitted to and confirmed by General Catterson and by other participants in the affair:

On the I $3^{\text {th }}$ of November, I868, Major Demby assembled at Murfreesboro about 360 men of the First Arkansas Cavalry,-all white. Learning that the enemy had a supply of arms stored at Centre Point, he sent 
Captain Reeves with about 100 men to seize them and there await further orders.

General Catterson and his staff arrived at Murfreesboro that night. The next morning the command marched to a place within seven miles of Centre Point, where they met Captain Reeves retreating, who reported the enemy at Centre Point about 500 strong, whereupon General Catterson ordered Major Demby with four companies to take the advance. Coming in sight of Centre Point, Major Demby saw a force of fully 400 men forming in line of battle; whereupon he ordered Captain Reeves, with his company, to march to the rear of the town on the Mt. Ida road, and he ordered Lieutenant Cotton with his command to the left to occupy the Nashville road, while he himself marched upon the town by the Murfreesboro road.

While Major Demby's command was crossing a creek running through the outskirts of the town the enemy, under shelter of the houses, fired upon his troops, killing one man and wounding five. While this was progressing Captain Reeves struck the enemy in the rear, which threw them into confusion and enabled him to take a considerable number of prisoners. The enemy formed again behind a church in front of Major Demby, while he rallied his men and charged them, whereupon they fled in the utmost disorder.

At this time a gun shot was fired from a building, which the militia immediately occupied. They found the upper story to be the den of the Ku Klux Klan, with their disguises hanging about the walls, and with a Confederate Flag spread over the altar where candidates knelt and took the prescribed oaths. The room was empty, but they discovered a trap door in the ceiling and hoisted one of the militia on the shoulders of another, who thus succeeded in entering the loft, where he found 
several men concealed. They were arrested, and among them was John Crawford, an ex-Confederate Major and the defaulting State officer referred to on page 365 .

The militia having occupied the town, the enemy in great confusion sought places of concealment. Some of them were dragged by the militia from a space between the ceiling of a porch and the roof, and others from every imaginable hiding-place. The whole number of prisoners taken throughout the affair was about 6o. General Catterson, mistaking my power in the execution of martial law, - which was confined to the counties enumerated in the proclamation,- -sent to Little Rock to be turned over to me all the prisoners above referred to. I immediately sent them all back to General Catterson with orders to investigate the circumstances and release such men as were not charged with any special crime against the laws of the State and to organize a military commission for the trial of such offenders as were charged with high crimes. The proceedings and verdict of said military commission were to be referred to me for my approval before being carried into effect.

The result of this affair created a profound impression in all localities throughout the State, and even beyond its borders, and caused the $\mathrm{Ku}$ Klux bodies heretofore mentioned as having been on their way to Centre Point to countermarch to the localities from whence they had come.

$\mathrm{Had}$ it not been for the quickness of perception and promptness of action that characterized General Catterson's operations and his immediate and vigorous attack upon the enemy without parley or delay, the assembling of this very considerable insurgent force might have turned the tide against the State Government and led to the most serious results. 
The Centre Point affair was followed by three incidents of far-reaching importance. A negro man, charged with an assault upon a white woman, was arrested within General Catterson's jurisdiction and tried by a military commission. He was found guilty, sentenced to death, and, with my approval, publicly executed at Rocky Comfort, Ark. The second was the trial and conviction of E. R. Griffith, commonly known as "Bud" Griffith, for having been one of the participants in the murder of Major Andrews, Lieutenant Willis, and the unknown colored man. ${ }^{6}$ He was publicly executed at Rocky Comfort, Ark. The third was the killing of the notorious desperado and bandit, Cullen Baker, the particulars of which were correctly described in the article in the Washington Telegraph, which was republished in the Gazette, January 26 , I 869 , as follows:

"Death of Cullen Baker. This man, who has probably caused more excitement and committed more crimes than any man in modern times, has at last fallen, and the country breathes free once more.

"The circumstances of his death are as follows:

"About four weeks since, he went to the house of his brother-in-law, Mr. Thos. Orr, in Lafayette County, Ark., and, breaking down the door, took Mr. Orr and his father-in-law, Mr. Wm. Foster, tied their hands behind them, and kept them during the night. Next morning he hung $\mathrm{Mr}$. Orr until he supposed he was dead, when he cut him down to get the rope to hang another man. This man was finally released by some of Baker's men. Mr. Orr recovered after Baker and his party left. Mr. Foster they released about I 2 o'clock that day. On the 6 th of January, Baker and a man named Kirby came into the settlement again, and Mr. Orr, with a few friends, determined to kill him or sacrifice their lives in the attempt. While concealed in the woods they rushed on him and succeeded in killing him about I I o'clock ...." 
The execution of the negro taught the lawless element that under General Catterson's rigid rule they might expect, if apprehended, such exemplary punishment as the nature of their offenses should demand.

The arrest and execution of Griffith showed that General Catterson was not groping in the dark, but knew whom to lay hands upon, and that while the object of martial law was not to punish members of the Ku Klux Klan as such, it was to ferret out and bring to justice those members who had been guilty of high crimes.

On September 3, I868, Baker's operations having been brought to my attention, and especially his recent murder of one J. Smith, I had issued a reward of $\$ \mathrm{I}, 000$ for his arrest and delivery to the proper officer $;^{7}$ whereupon he posted upon the trees and public places in the vicinity of his operations a reward of $\$ 5,000$ for my delivery to him, dead or alive. After the killing of Baker his body was brought to Little Rock, and after full identification the reward was paid.

The execution of Griffith and the killing of Baker caused a panic and general exodus among the desperadoes who, as members of the $\mathrm{Ku}$ Klux Klan and under its protection, had carried on their nefarious operations "without let or hindrance" in the southern part of the State.

The location of this band was well chosen for their purposes on account of the ease with which they, if pursued by an officer of the law, could fly beyond the jurisdiction of Arkansas to the States of Louisiana, Texas, or the Indian Territory, which all cornered within a comparatively small area.

After these favorable occurrences General Catterson's work of reëstablishing the civil authorities in the counties named and in other counties under martial law in his district was comparatively easy. He found that a 
large percentage of the citizens in a number of counties had joined the Ku Klux Klan in the belief that its object was to protect the whites against their exaggerated ideas of negro domination. This class, having been drawn forward step by step by their Ku Klux leaders, at length found themselves verging on or in a state of insurrection against the lawful authority, and were under such terrorism as to cause them to fear the vengeance of the order, should they desert it. They now began to look upon the militia as their liberators, not as their enemies, and many were ready to pledge themselves to support the reëstablishment of the civil authorities and to join in the punishment of the outlaws, should they return.

General Catterson, having become satisfied of their good faith and having received assurances of their determination to support the civil authorities, reported these facts to me with his recommendation that martial law be revoked in the counties within his territory, which was done under my proclamation referred to in my message to the Legislature, January I 2, I $869 .^{8}$

\section{COLONEL MALLORY'S MILITARY OPERATIONS}

I now come to a description of the condition of affairs in Col. Samuel W. Mallory's district and his militia operations.

On the 3 oth of November, I 868, Capt. George Prigmore assembled at Monticello three companies of colored troops, - one from Little Rock and two from Pine Bluff. On the Wednesday following Colonel Mallory arrived to take command of his district.

Early in December, I 868 , Messrs. Haynes, Brooks, Whitington, and Wells,-all prominent citizens of Drew County, representing both political parties and duly selected by its citizens, - called upon me at the Capitol to 
discuss and if possible devise ways and means preparatory to the restoration of the civil authority in that county. In the deliberations that followed I became very much impressed with the good faith of this Committee. The result was that they agreed to go back to Monticello and raise two home companies of non-partisan membership,- - one of cavalry and one of infantry,upon which I could rely under all circumstances to obey the orders of the commanding officer of that District.

On their return to Monticello, Captains H. C. Burks and James A. Jackson redeemed the promise of the Committee by the prompt enlistment in the State Guards of the two companies referred to, and they and their subordinate officers were duly commissioned by me. I have only the muster roll of Captain Burks' company,-which economy of space prevents me from publishing,-but I can say that, including the two lieutenants, the full strength of this company was 74 men, who, with the exception of about fifteen, were all ex-Confederate soldiers, and two were ex-members of the Ku Klux Klan.

Shortly after the occupation of Monticello by the militia Stokely Morgan was arrested, having been charged with complicity in the murder of Deputy Sheriff William Dollar and a negro named "Fed" Reeves. The atrocity of these murders is shown by the following well established facts: Deputy Sheriff Dollar was serving a writ and was killed by a gang of some fourteen Ku Klux. Then, in order to make an impressive tableau, they killed "Fed" Reeves, an unoffending negro, and tied the white man and negro together in the attitude of kissing and embracing, and left them in the public road where they remained for about two days. During this time, to gratify their curiosity, many people visited them and left them as they found them.

In due time a military commission was convened, 
composed of the following members: Col. Samuel W. Mallory, Capt. George Prigmore, Captain Bushmyer, Capt. H. C. Burks, Capt. J. A. Jackson, and Lieut. Thomas Haynes.

The three members last named were officers in the two home companies. The unanimous verdict "guilty" rendered by the military commission was based principally upon the evidence of an aunt and an uncle of the accused, and the verdict was publicly carried into effect by a detail commanded by Colonel Demby, assisted by the two Monticello companies, who were charged with the keeping of order. The execution of Morgan had a very salutary effect, resulting immediately in the flight from the State of thirteen desperadoes from the County of Drew, who were never permitted to return.

A great deal of the foregoing information is based on a letter in my possession from Capt. H. C. Burks to S. A. Duke, dated November I, 1906, which Duke delivered to me with permission to use. As I do not believe that the facts which I have stated will be questioned, I omit its reproduction.

On February 6, I869, I issued my proclamation revoking martial law and restoring the civil authorities ${ }^{9}$ in Colonel Mallory's district.

The mustering into the State service and the active use of the two home companies referred to was a masterstroke of peace-restoring policy. During my administration and ever since I have kept informed as to the history of Drew County, and I unhesitatingly express the opinion that its citizens have justly earned the reputation of being among the most peaceable and law-abiding of any county in the State. 


\section{GEN. D. P. UPHAM'S COMMAND}

The civil authority in all the counties south of the White River having been restored, I now proceed to give an account of the administration of martial law in the northeast military district under the command of Brig.-Gen. D. P. Upham.

On December 8, I 868, General Upham assembled a force of about one hundred and twenty white soldiers at Augusta, Woodruff County, and proceeded at once to fortify his position by the erection of a stockade, and soon thereafter he occupied the Counties of Craighead and Greene with suitable forces.

During the period that General Upham was assembling and organizing his command at Augusta, several extravagant reports came to me of abuses and depredations charged to his troops. I therefore sent Adjt.-Gen. Keyes Danforth to inquire into and to investigate thoroughly these rumors. As his report is an important document I republish it in full. ${ }^{10}$

"His Excellency Powell Clayton,

\section{"Little Rock, Ark., \\ "December 12, I868.}

"Governor of Arkansas,

"Little Rock, Ark.

"DEAR SIR: In compliance with your instructions I left the city on the morning of the Ioth instant, arrived at General Upham's headquarters at Augusta on the Ioth, returning here this evening. I respectfully submit the following report of affairs as I found them there. "At De Vall's Bluff, and other points on my way up White River, I heard extravagant reports of depredations committed by General Upham's command, all of which I am glad to report, upon a thorough investigation, proved to be untrue.

"I found General Upham located in a house (which 
was unoccupied when he took possession of it) protected by a strong stockade. Some of his troops were quartered inside the defence; others in such buildings as were found tenantless in the town.

"His force amounted to about one hundred and fifty white men, tolerably well armed and mounted. He moved from Batesville with one hundred men, only a portion of whom were armed. Upon his arrival in Augusta he immediately seized all arms and a large amount of ammunition in the possession of the merchants. He had taken such clothing and quartermaster's stores as were needed by his men, and nothing more that I could ascertain. I am satisfied that his command has not taken the property of the citizens in any case where it was not actually needed. On the night of the 9 th instant General Upham had reliable information of an intended attack by a force of insurgents, estimated to number from three to four hundred men. He at once arrested fifteen of the leading sympathizers in town and confined them in a brick building, and sent notification to the citizens that if he were attacked he would kill his prisoners and burn the town. Upon this, several influential men went outside of the town and prevailed upon the attacking force to abandon their intentions and return to their homes, which it is believed has been done. General Upham told me that a detachment of his troops had been fired upon while marching to join him, and had committed some depredations immediately upon their arrival in town; and that he had caused their arrest and returned the goods to their owners. He assured me that he would maintain strict discipline and allow no seizures of property except by officers under proper orders. He feels perfectly confident of his ability to defend successfully his position against any attack which may be made upon him. On the morning of the Ioth he sent out a detachment to ascertain if there were any armed men in the county. If there were not, he intended to release all but two or three of his prisoners (who are desperadoes) 
and to do all in his power to restore a feeling of security and confidence among the people.

"General Upham has no colored troops in service; but intended to put into camp the colored companies in Woodruff County. I respectfully recommend that this be not done except in case of extreme necessity. I found the people in Augusta very much frightened; a few of them had gone away. The merchants had shipped a small portion of their goods. When I left, however, a better feeling had begun to prevail and the excitement was rapidly dying away. I do not think it was so much the presence of the militia which agitated the people as the fear of an attack from the outside upon General Upham's troops. General Upham's ideas about restoring civil law as soon as possible and using as few men as possible accord fully with your own views. He thinks a month or six weeks will end militia operations in his district. He also recommends that civil law be restored in Fulton County at once.

$$
\begin{aligned}
& \text { "I am, very respectfully, } \\
& \text { "Your obedient servant, } \\
& \text { "KEYES DANFORTH, } \\
& \text { "Adjutant-General." }
\end{aligned}
$$

I am glad to say that General Danforth's report fully exonerated General Upham and his command. On the I 5 th and $22 \mathrm{~d}$ of December, I 868 , General Upham transmitted to me two reports ${ }^{11}$ relative to militia operations in Woodruff County, copies of which are as follows:

"Governor Clayton,

$$
\begin{aligned}
& \text { "Augusta, ARK., } \\
& \text { "December I 5, I868. }
\end{aligned}
$$

"DEAR SIR: I have the honor to make the following report:

"A large force numbering about two hundred (200) of the citizens of Woodruff County gathered together, armed, to resist the State troops, and the citizens of 
Augusta went out and met them day before yesterday and caused them to lay down their arms and return to their homes; all except a few are outlaws, among which are the men who shot McClure and myself on the $22 \mathrm{~d}$ of October last; the others are men of the same character. Last night, about ten o'clock, our pickets were fired upon by a party of about one hundred ( I Oo) men from Sharp, Lawrence, and Jackson, joined by the aforesaid few outlaws of this county. They immediately retired about five miles above here on my plantation, camped overnight, and took my overseer, Richmond Briscoe, and Captain Anderson prisoners. This morning they made a move in the direction of Augusta.

"We are about one hundred and twenty (I20) men, half armed. We can hold the position until Dale and Monks arrive, who are on their way with about two hundred men. Send us, if possible, about one or two hundred stands of arms and some ammunition. The rebels will probably get together six or eight hundred men within a week. Colonel Schaurte can give you some information. We are anxious for a fight, and our men will do all they can with what they have to do it with. I don't care for reinforcements if we have arms. The citizens under my orders are bringing some every day. The telegraph operator, Holman, is a $\mathrm{Ku}$ Klux and made his escape last night after giving all the information he could to Jacksonport. Send an operator. The good citizens have been here this morning begging for arms to fight with us, but we have none to give. We are in fine spirits and every man will fight. The citizens have just presented an address to the citizens of other counties, praying them to desist and let this county alone, as they are well satisfied and wish no interference from any quarter. I will send you copy by next mail.

"I have the honor, Governor, to remain

"Yours with great respect,

"D. P. UPHAM,

"Brig.-Gen. Commanding." 


\section{"Augusta, Ark., \\ "December 22, I 868. \\ "His Excellency, Hon. Powell Clayton, Governor, "Little Rock, Arkansas.}

"Governor: My report to you on the 15 th contains about all that could be said. Captain Taylor with a detachment of about fifty (50) men followed the outlaws from Jackson and other counties two days and nights, and at last drove them into Jackson County. I telegraphed to Captain Brian to arrest Bob Shaver and notify me, but as yet have received no notice of the arrest of Shaver, who was in command of all the insurgents north of Woodruff County, and a resident of Jacksonport. Under his direction and superintendence were the $\mathrm{Ku}$ Klux, with Col. A. C. Picket at the head, and Capt. A. W. Robertson and Lieut. B. Y. Jones, who have furnished me with the original roll of one company, named as follows:

"Capt. A. W. Robertson,

B. Y. Jones, Ist Lieutenant,

H. H. Hammock, 2d Lieutenant,

\section{"Privates:}

W. B. Yarber,

A. L. Harralson,

S. M. Crutchfield,

T. A. Spradlin,

James Harris,

E. M. Hughes,

John Q. Shields,

H. C. Mondy,

John Home,

B. M. Yarborough,
R. B. Harris,

William Harris,

J. T. Spradlin,

William Hughes,

Merideth Williams,

John Brown,

Robert Jennings,

F. M. Spradlin,

J. B. Q. Shields,

Joseph Carden.

"There are several other companies which will be reported in future. 
"The aforesaid Col. A. C. Picket was with Bob Shaver, commanding insurgents of this county. He is a lawyer of Augusta and recently connected with the Augusta Sentinel.

"The greater portion of the Ku Klux of this county are young men, who have been called upon by these 'hightoned gentlemen' and 'law-abiding citizens,' invited to ride with them at night, and taken out in the woods and sworn in without knowing what the nature of the organization was until they were in it. The headquarters of Bob Shaver while in this vicinity were at my house, on the Jacksonport road, and they stole and destroyed everything, taking away the last thing in the house and every horse and mule on the place. The citizens are now in favor of the administration as it is. I can, the last of this week, proceed to Craighead and Greene. I would respectfully recommend the restoration of civil law in this county at an early day, and that martial law be proclaimed in Jackson county. I have ordered the arrest of Bob Shaver, ${ }^{12}$ and report says he is now under arrest. Next mail will convey to you a healthy state of affairs in Woodruff county.

"I am, Governor, yours with great respect,

$$
\text { "D. P. UphaM, }
$$

About this time a delegation composed of Col. A. C. Picket, Hon. C. L. Gauze, and John W. Slayton, called on me at the executive offices in Little Rock, Ark., with the avowed purpose of having the civil authority restored in Woodruff County. Colonel Picket was the spokesman, and commenced by saying, "Governor, I know not how it is in other counties in the State, but we can assure you that there are no Ku Klux in Woodruff County." At this point $\mathrm{I}$ interrupted the Colonel and drew from a drawer in my desk a list of the Ku Klux Klan of Woodruff County sent me by General Upham a few days be- 
fore. Handing it to him, I remarked: "Colonel, please look over this list, and I think you will find that your name, like that of 'Ben Adhem,' leads all the rest." The Colonel glanced over it, and before he had time to reply I said: "Now, gentlemen, don't come to me with lies on your lips. If you will go back home, and in good faith disband the Ku Klux organization there, and furnish me with conclusive evidence that you have done so, and I have means of knowing whether you do or not, I will revoke martial law and restore the civil authorities there."

The Colonel and his associates seemed much crestfallen, and for a time they were speechless. At length they agreed that they would go back and comply with my requirements, which in due time they did. This I learned from General Upham and from other sources of information, whereupon on December I4, I868, I by proclamation restored the civil authorities in Woodruff County.

Years afterward, when Colonel Gauze became a member of Congress from that district, he and I frequently laughed over this Picket episode. He told me that they had made life almost unbearable for the Colonel on their way back to Woodruff County because of the sudden termination of a speech that he had previously prepared and read to them.

General Upham had been threatening the declaration of martial law in Jackson County, and on December I7, I868, William Brian and John W. Slayton visited General Upham at Augusta for the purpose of averting the application of martial law to their county. In their letter of December 17,1868 , addressed to E. L. Watson, W. K. Patterson, and others, relative to affairs in Woodruff County, published in the Republican of December 22, I868, the following language occurs: 
"The people here in this county have, with few exceptions, submitted and pledged themselves to assist the civil officers to enforce the laws. We have conversed freely with them and they earnestly desire and implore citizens outside from other counties not to attack or offer any resistance whatever to the military. It is the utmost folly and murderous to do so. ..."

OPERATIONS OF THE MILITIA UNDER COLONEL IVATSON

An account of Colonel Watson's militia operations from the time he left Helena until he returned to that city and mustered out his command is given in the following communication to me from him, dated October 3, I 889:

"In accordance with your orders in the fall of I 868 , I organized four companies of Infantry: In Helena one company; in St. Francis one company, and in Crittenden County two companies. These were made up of colored men. The officers were white except two second lieutenants who were colored men.

"I had to arm my men as best I could, there being no state arms for my use. The same is true as regards ammunition and clothing. Many of the men had not sufficient clothing to protect them in ordinary weather under shelter, much less when exposed to the severe weather we encountered.

"All of my officers and most of the men had seen much service in the war. On December 24, '68, I marched from Helena with the four Phillips County companies en route for Madison. Phillips County being under Civil Law, I invited the sheriff to accompany me through the county, which he did. On the night of December 25, while encamped in the woods near Madison, six inches of snow fell on us. This caused much suffering among the men. 
"I reached Madison on the 26th. Here I let it be understood that I was going up Crowley's Ridge to the counties above. I remained in Madison about two days to permit the assembling of the St. Francis company. On the night of the 28th (I think) about nine o'clock I took possession of the telegraph office, and the passenger engine on the Memphis and Little Rock Railroad, then only running from Memphis to Madison. I ferried my men across the St. Francis in an old flat boat and by daylight was at Hopefield and on my way to Marion, eight miles distant, having nearly reached the latter place before my presence in the vicinity was known.

"When two miles from Marion I was met by Lieutenant-Colonel Main and Captains Haynes and Cook, who had organized the two companies in Crittenden County. With the assistance of Main I mounted a squad, and under his command they dashed into Marion, capturing a lot of the desperadoes who had committed so many outrages in the county. I then moved into Marion and put up a strong stockade. I found a terrible state of affairs in Crittenden County. The better class of citizens was completely cowed by the desperadoes who held complete possession of the county.

"Many citizens of the county, both Republicans and Democrats, told me the organization of the Ku Klux was so nearly universal that no man, if he were opposed to the existing state of affairs, dared speak to his neighbor on the subject. Consequently, no organized movement could be made, and there was no possible solution of the matter except by martial law.

"I was attacked several times at night. In one of these attacks we killed one of the attacking party, and I learned that several were wounded. After I had been at Marion a short time Lieutenant-Colonel Monks reported with (I think) six companies of cavalry. He had been ordered to me by General Upham. He had a good body of troops under good discipline and all white men from the northwestern part of the State. 
"Soon after the arrival of Colonel Monks, General Upham came over to Marion on a tour of inspection. He took Colonel Monks and his cavalry and went up to Mississippi County, and placed him in command of that county. When General Upham left Marion he took with him four of the prisoners I had captured, intending to take them to Augusta and send them to Little Rock, they being the most notorious of the outlaws I had captured. On the march to Mississippi County these men attempted to escape and were killed.

"Shortly before this time, four colored men belonging to the Helena Company committed rape on two white women. I had them arrested and brought before a Court Martial. They admitted their guilt and were sentenced to be shot to death, which sentence was carried into effect. The firing squad in the execution was composed entirely of colored men. They executed their orders without a comment, which shows a good state of discipline for militia. In justice to the colored men of the command I must say they favored the execution of these men in vindication of themselves.

"One of the prisoners I had captured, named Moffard, was charged with several murders and with shooting Captain Barker of the United States service, who was stationed at Marion. I ordered a Military Commission for his trial. Moffard was tried, clearly proven guilty, and sentenced to be hanged, which sentence, with the approval of the Governor, was executed. Both of the Courts above mentioned were composed of my most experienced officers, men who had seen long service. I had little difficulty in enforcing strict discipline. If the men could have had uniform clothing and arms, they would have compared favorably with any troops.

"The Appeal and Avalanche, papers published in Memphis, published almost daily what purported to be accounts of killings and outrages in Crittenden, giving lists of names of people who had never been heard of in the county. These stories were all entirely false ex- 


\section{CIVIL WAR, IN ARKANSAS}

cept so far as justified by above facts. Several parties who came over to see how matters were tried to stop these false stories, but without avail. Among these were Dr. McGanock, for whom I had a safeguard from the Governor, and a committee appointed by a meeting in Memphis. All these told me they found the reports to be false and would have them corrected. But it did not suit the purposes of these papers to publish the truth.

"The commanding officer of the United States troops at Memphis (General Granger, I think) sent one of his staff over to call on me and see for himself. I took care to let him see everything. He reported to the General that the published accounts were nearly all false, that my command was as orderly as could be under the conditions surrounding us.

"At first there was a strong effort made in Memphis to raise a force to come over and drive me out. A large force was organized in the city and surrounding country, but they did not make the attempt.

"After my skirmishes a large number of the worst men in the county left the State; some of them never returned, I am told. After everything had quieted down I sent the St. Francis company home, leaving Colonel Main in command with the two companies belonging in that county. I took the companies from Helena home and relieved them from duty in time to commence their crops.

"My memory of what occurred in Mississippi County under Colonel Monks is very indistinct. I think he is living in Missouri some place.

"The last I knew of Colonel Main, he was in charge of the National Cemetery at Fort Smith. He could give you a statement of affairs in Crittenden before martial law was declared. I cannot speak too highly of Main. He is a man of remarkable courage and good judgment. His war record was brilliant.

"What I have written is from memory, but every 
statement is correct. As I told you, much of my record was burned in my office at Helena. I do not know what troops Upham had over on White River and do not remember much of what occurred there. . . ."

About January 8, I 869, General Upham left Augusta on a tour of inspection of the troops in the counties of Craighead, Greene, Mississippi, and Crittenden. Having heard, through Memphis sources, so many disparaging reports relative to the conduct of the militia in Crittenden County, I concluded to visit General Upham and make a personal investigation. For that purpose I arrived in Memphis with my staff on the evening of January 25, I 869, and left for Marion, Crittenden County, the next day, where I remained several days and thoroughly investigated the reports referred to.

I regret very much that I have no detailed written report from General Upham covering the period of his tour of inspection, the lack of which can only be accounted for upon the theory that, having thoroughly gone over the ground with me in my investigation at Marion, he concluded a written report was unnecessary. I can only say that the final results of my investigation completely vindicated General Upham and Colonel Watson in the conduct of their respective commands, and agreed substantially with the report of Generals Babcock and Porter to General Grant, and with the written report of Brig.Gen. R. B. Ayres, of Colonel Rousseau's staff, which was transmitted to the War Department, and reads as follows: ${ }^{13}$ 


\section{"DEPARTMENT OF LOUISIANA}

"Acting Assistant Inspector-General's Office,

"New Orleans, La., Jan. I9, I 869.

"B'vt.-Brig.-Gen. Thos. H. NeILl,

"Act. Asst. Adjt.-General,

"Department of Louisiana.

"GENERAL: I have the honor to submit the following report concerning affairs in Arkansas as observed in my recent visit to that State, made pursuant to S. O. No. I04, series of 1868 , from these Headquarters.

"At the close of the Civil War society was greatly disorganized in Arkansas, especially in those portions of the State where the population is sparse and scattered, and the substitution of Civil Law for the military rule has been attended with unusual difficulties and progressed slowly in those regions. Desperate characters, accustomed to lawlessness, have continued to commit acts of violence and outrage with impunity. The law-abiding citizens, having become accustomed to those things by the frequency of their occurrence, considered them as a matter of course; and from that and other causes failed to give that countenance and support to the civil officers that was essential to the full and fearless performance of their duties. Those officers, in many instances, were intimidated and in fear of personal violence, so that the execution of the law was always attended with difficulty in the localities referred to, and the attempt to execute it often resulted in entire failure, and it came to be considered by the Executive Authority of the State that it was necessary to adopt some course whereby the supremacy of the law should be established, the outrages stopped, and the outlaws brought to justice or driven from the State.

"Several methods were suggested whereby the desired result might be obtained. One was to place small detachments of United States troops in each of the disturbed counties, to act as a posse in assistance of the 
sheriff, and application was made to the Department Commander for troops for this purpose, but he did not deem it advisable to make the disposition recommended. This would have been at best but a temporary expedient of no longer duration than the presence of the troops; moreover, the calling upon the United States Government for assistance would of itself have been considered as an acknowledgment of the failure of the State Government and the civil authority. Another method was to enroll a small force of militia in the disturbed counties, to act subordinate to, and in assistance of, the civil officers; but their sphere of action was deemed too limited to ensure more than partial results.

"Another plan, and the one adopted, was to place the several counties wherein the execution of civil law was a failure under martial law, to divide the State into Districts, and to organize a movable force of militia to pursue and arrest or drive from the State the ruffians and outlaws.

"In pursuance of this plan the State was divided into the Districts of the Southwest, the Northwest, the Northeast, and the Southeast, and commanders were assigned to them. The force in the Southwest district was opposed by an armed band, with which it had a conflict at Centre Point, resulting in the killing of several of the insurrectionists, the capture of others, of arms, etc., and the dispersion of the remainder. A band also organized to resist the force in the Northeast District near Augusta, but the persons composing it were persuaded by the citizens of that town to disperse without a conflict.

"The result of the plan adopted has been that the substantial, law-abiding citizens of the several counties placed under martial law have held meetings and pledged themselves to support the civil authorities and to assist the civil officers, when necessary, in the performance of their duties. A result certainly of the most gratifying character and promising peace, and the due execution of the laws in the future. 
"In each county where these guarantees have been given the civil authority has been restored and martial law now exists in but one or two counties, and it will doubtless soon cease to exist in the State. As regards the alleged outrages by the militia, the reports thereof are great exaggerations and many of them pure fabrication. It would be impossible anywhere to call into existence a force as this has been, for temporary purposes, and not have violations of orders and military law.

"There was no other way to maintain the militia but to subsist it on the county-collecting supplies by a system of contributions levied on the people, giving receipts therefor with a view to future payment; and I was assured the commanders used their best endeavors that this should be done in a proper manner. Subordinates at times doubtless exceeded their orders; also persons not of the forces, but representing themselves as belonging to them, in some instances plundered the people. In cases where orders were disobeyed and instructions departed from, the delinquents when detected were punished according to the military code. A gross outrage was perpetrated by a militiaman of the Southwest command. He was promptly tried and executed.

"As fast as the civil authority is established the militia forces are disbanded; and it is confidently believed that the civil law can be enforced in the future by the officers thereof, and that a resort to the military power will not be again necessary.

"Respectfully submitted,

$$
\begin{aligned}
& \text { "(Signed) R. B. Ayres, } \\
& \text { "Lt.-Col. 28th Inf., Bvt.-Maj.-Genl., } \\
& \text { "A. A. I. G." }
\end{aligned}
$$

It is to be regretted that Colonel Watson did not give the names of the four men he refers to as having been killed in an attempt to escape on their way to Mississippi County from Marion. However, I have an indistinct 
recollection that, during my investigation at Marion, General Upham gave me the names of these men. I remember that during the progress of my investigation with General Upham I first regarded his statement as to the killing of the four men as unsatisfactory, but he convinced me that in this case they actually were attempting to escape when they were fired upon at short range by the guards and killed.

In recognition of the invaluable services rendered by Colonel Watson, prior to his muster out, I promoted him to the rank of Brigadier-General.

CONDITIONS EXISTING IN CRITTENDEN COUNTY PRIOR TO COLONEL WATSON'S OCCUPATION

The following extract from a letter from Col. E. M. Main, dated February 5, r9 10, shows the condition of affairs existing in Crittenden County prior to its occupation by Colonel Watson:

"I have read Colonel Watson's statement of the operations of the State troops under his command in Crittenden County, which I think in the main is correct. The statement coincides with my recollection of those events. There may, however, be some minor events that have escaped our memory, but I think Colonel Watson's statement covers the most salient points.

"I might here mention the fact, evidently overlooked by the Colonel, that at the time he arrived with the State troops the enemy had a pretty well organized force of several hundred men, and they amused themselves by driving in our pickets every night for some time, or until the arrival of Colonel Monks with his cavalry when we raised the siege, before which there was more or less skirmishing every night.

"Before Colonel Watson arrived there were open and 
bloody threats against the State troops, and that they were prepared to carry out these threats was evident.

"Relative to the condition of affairs in Crittenden County previous to the declaration of martial law and the arrival of the State troops, I must say that the county was in a most deplorable state of disorder. In fact a reign of terror, intimidation, and murder prevailed. The vilest passions of the worst element of the community seemed to be aroused and bent on evil doing, and no one dared to raise voice or hand in protest, and the saturnalia of crime went on unchecked.

"Mounted men in disguise,-Night Riders, Ku Klux, or what you please to call them,_-raided and re-raided the county, leaving a trail of blood wherever they went and filling the land with the wail of orphan and the agonized shriek of wife and mother. Then it was that the cry was raised, 'Murder and no law!' Both white and colored citizens, - the proscribed 'Yankee and Nigger,' - fell victims of this thirst for blood. Specific cases with uncontrovertible proof were not lacking, but the law was paralyzed,- the public conscience was dead.

"Among the first to fall a victim to this thirst for blood was Capt. E. G. Barker, agent of the Freedmen's Bureau, with his office at Marion. In this case, as in many others, little care was taken at concealment. Captain Barker was shot through the open window of his office in the early dusk, in the most public part of the town, and was left to his fate, no one daring to go to his relief. I was living on a plantation two miles from Marion, where the news of the shooting was brought to me by a colored man. I proceeded at once to the scene of the shooting, accompanied by Captain Haynes and four colored men. We found Captain Barker prostrate on the floor, where he had fallen when shot, drenched in his own blood. He was unconscious. Two large buckshot, evidently fired from a shotgun, had entered his head, and two shot had shattered his wrist.

"On an improvised stretcher, made from articles 


\section{I36 THE AFTERMATH OF THE}

found in his office, we had him carried from the place, passing through a jeering mob of half drunken men as we emerged into the street. It was evident that the man, or men, who had done the shooting were among this mob. We had Captain Barker carried to our house and a doctor summoned,-J. H. Southall, an ex-Confederate. Subsequently Dr. Southall told me that he attended on Captain Barker at the peril of his own life, that he had been notified that if he did so it would be at the peril of his life. All honor to Dr. Southall. He gave Captain Barker his closest attention, making daily visits, going armed himself as a precaution against attack. Dr. Southall was a Virginian, a Harvard graduate, and a surgeon in Forrest's Cavalry. He frequently expressed himself strongly against the lawlessness in the county. There were honorable, law-abiding men of both political parties in Crittenden County, but they were overawed by the desperadoes who set all law at defiance, arraying neighbor against neighbor, and bringing trouble and reproach upon all.

"Captain Barker was a Christian gentleman; his only offense seemed to be in doing his duty faithfully as an agent of the Government. He organized Sunday Schools among the colored people, which was objectionable to a certain class of white people. He was zealous in safeguarding the rights of the colored people in the matter of contracts for labor, but no less so in the interests of the employer-planter. I know that he was scrupulously conscientious in the discharge of his duty, always counselling patience and forbearance on the part of the colored people, seeming to realize the fact that, the labor system of the South having been revolutionized, it became necessary to exercise tact and judgment in order to minimize the friction that would evidently arise between employer and employees.

"Captain Barker had rendered gallant service in the Union Army, as was attested by an empty sleeve. He served, I believe, in an Iowa regiment. When Captain 


\section{CIVIL WAR, IN ARKANSAS}

Barker was shot I was holding a position as clerk in the Freedmen's Bureau, and was instructed to take charge of the affairs of the office. The inflamed condition of the county increased to such an alarming extent that hundreds of colored people flocked to my plantation for protection, and the situation became so threatening that I appealed, as an Agent of the United States Government, for protection, ${ }^{14}$ which appeal was answered by a lieutenant with a detail of United States soldiers reporting to me for duty. This detail was quartered on my plantation, acting as a guard for the Freedmen's Bureau only, and was withdrawn on the arrival of the State troops under Colonel Watson.

"Previous to the open outbreak and the defiance of law, Captain Haynes and myself had taken no active part in the political questions that then agitated the county, being content to pursue our business as planters, and we only made a stand when personally and unjustly assailed. We held no office nor sought any.

"On the departure of Colonel Watson and the Helena detachment of State troops, the command of the Sub-Military District, with the two Crittenden County companies, was turned over to me. From this time until civil law was restored and the troops disbanded nothing of special interest transpired, our efforts being directed to the restoration of peace, harmonizing the discordant factions, and restoring confidence, with, however, but partial success. The unbridled passions in the absence of law had inflicted wounds that only time could heal. The seeds of discord had been sown and a bitter harvest must inevitably follow. ..."

My visit to Crittenden County to investigate the questions heretofore referred to compelled me to pass through and return to the city of Memphis, Tenn., which was not only the headquarters of the Ku Klux organization in the South, but a place of refuge for the Ku Klux 
fugitives from justice from Arkansas. This trip subjected me to great personal peril.

On the way to Memphis during the night at a landing on the Arkansas side a man with a gun took passage on the boat on which my staff and I were passengers. Of course he immediately became the object of close surveillance by a detective who, to avoid suspicion of being connected with me, had taken passage on the steamer at Clarendon, Ark., on its way to Memphis. That night, soon after this man came aboard, and while I was in the cabin at the front of the boat, the center of a group composed of my staff and others, he was observed by the detective outside the glass partition that separated the cabin from the passageway, slowly moving backward and forward with his gun in his hand, peering through the glass and evidently trying to single out some person on the inside. After moving backward and forward and sometimes raising his gun and then lowering it again, he suddenly raised it to his shoulder and was taking aim when the detective, who had concealed himself nearby, instantly sprang upon him from the rear, and with the assistance of one of my officers disarmed him and placed him under arrest. When first seized and asked what he was doing he acknowledged that his sinister purpose was my assassination. Upon arrival at Memphis he was immediately sent to Marion under guard, and placed in the custody of the commanding officer there. When I was about to say good-bye to General Upham to return to Little Rock he asked me what he should do with this prisoner. I instructed him to organize a military commission and investigate the matter fully before acting,- - expecting, of course, that he would report to me the result of such investigation. This he failed to do, and it was not until several years thereafter that I learned from an officer 
who had served at Marion that the court, upon the prisoner's own confession, had found him guilty and sentenced him to be hanged, and that the sentence was carried into execution. Years afterward General Upham told me that this man, during his trial, had admitted that he was acting under orders but would not disclose the source from which they were received.

I do not say that I would not have approved the proceedings, but as they related to me personally I would certainly have given him every opportunity to divulge the names of his accomplices. Had they proved to be persons higher up, I would probably have remanded the matter back to the military commission for revision upon the theory that he was but a tool, and not acting on his own responsibility.

On my way from Marion to my official home in Little Rock I stayed a few days in Memphis, Tenn., where, on the invitation of Colonel Beaumont, General Upham and I, accompanied by my staff, attended a performance at the New Memphis Theatre. We had no sooner taken our seats than we became the "observed of all observers." A description of my visit to Memphis and this event will be found in the following article from the Memphis Post: $:^{15}$

"HIS VISIT IN THE CITY-INTERVIEWS WITH THE KU "KLUX-BOLD TALK ABOUT ASSASSINATING HIM

"Since Governor Clayton's arrival in this city on Tuesday evening, from a trip of inspection, accompanied by prominent military and judicial officers of his State, to the Headquarters of the militia force stationed in Crittenden County, he has been the leading theme of thought and speech of every citizen, be he a Ku Klux or a Republican friend.

"With his staff he has occupied rooms at the Overton, 
where, early and late, a continuous stream of friends wishing to pay their respects and of enemies anxious to gain his favor by obsequious pretensions of respect has poured through his room. Among the names of the prominent citizens and friends who have called to pay their respects are those of Judge Hunter, of the Criminal Court; Judge Waldran, of the Municipal Court; Attorney-General Thorn; Prosecuting-Attorney of the Municipal Court H. E. Hudson; Col. S. B. Beaumont, Superintendent of the Little Rock Railroad; Judge Vance, of Mississippi, now stopping in the city, and prominent Republicans of this place, together with several large property owners; among them W. R. Greenlaw, Esq.

"The interviews of these gentlemen have been of the most interesting character, and all have come away with a greater degree of respect, if possible, for the noble chieftain whose name has become a terror to the $\mathrm{Ku} \mathrm{Klux}$ Klan which infests his State.

"The rebels from the city and from Crittenden, many of whom have called upon him, have received the most cordial welcome and the kindest attention from him, and have also come away convinced that he is a worthy magistrate of his State, and one who demands nothing but justice to all.

"A conversation which he had with a citizen from across the river is too full of facts for the public to lose the benefit of it. The citizen's object in calling upon the Governor was, like that of most of the rebels who visited him, to learn when he intended to revoke martial law and disband the militia. Like the rest of his friends, the citizen pledged his honor as a gentleman that when those steps should be taken every good citizen in Crittenden would take measures immediately to enforce the laws and punish all offenders. The Governor replied that that was the result which he was seeking by the aid of the militia, and as soon as he became satisfied that the people would do what had been pledged, then they should at once be relieved of the militia. The promise pleased 
the citizen, and he plied his specious pledges more heartily and grew eloquent in extolling the character and wishes of the good citizens of his county.

"In order to test the man's idea of a good citizen, the Governor asked him his opinion of Maj. J. F. Earle and B. C. Crump, of his county. With a look of surprise that the character of these men should be questioned by the Governor, the citizen replied with great emphasis that both were among the best citizens; that they always counselled order and quiet and obedience to the laws of the State. He would have expatiated a whole hour on the exemplary character of these men, probably, if the Governor had not relieved him of that trouble by telling him that Earle was the Commander of the 'Knights of the White Camelia,' and that Crump was the leading spirit and active worker in the organization! The confusion of the citizen at this statement was sufficient to convince the Governor of the correctness of his statement, even if he had not had the additional evidence in the form of sworn statements from the members of the organization themselves, revealing the whole history of that lawless organization.

"When it is expedient that the facts should be given to the public the Governor's information of the operations of the outlaws in his State will be found to be perfect.

"Yesterday afternoon the Governor enjoyed a ride around the city. In the evening he attended the $\mathrm{New}$ Memphis Theatre, accompanied by his staff. Soon after his presence in the theatre became known the word was whispered around by the blood-thirsty rebels present, and they began to gather in little knots in the passage-ways skirting the theatre, and to talk in audible tones about assassination.

"The epithets 'murderer, ravisher, and thief' were mingled with expressions of vengeance to be heard in portions of the audience. One of the unterrified was heard to say to a comrade, 'How would you like a good 
dagger to throw at the villain?'- 'That would be all right,' was the flippant reply. The public officers present kept a vigilant watch, and the rebel fiends had not the heart to risk an assault, and the Governor, whose personal courage is of the highest order, returned to the hotel in safety."

It having been noised abroad that we would attend the theatre, the audience was so large that many people could only procure standing room in the aisles near the entrance to the foyer. Frequently I observed them pointing us out, and it was evident that we were the subject of their conversation. When the performance was finished we found it difficult to make our way to the foyer, hence the theatre was almost completely empty when we reached the principal street leading from it. To our surprise the sidewalks on each side of the street for several squares were jammed with a hooting, howling mob, making it dangerous for us to attempt to jostle our way through it. Hence we took the middle of the street as the safest way for us to reach our hotel, and as we walked in this strange procession we realized that to endure the insults of the mob was the "better part of valor," and although we did not show our apprehensions, we were all greatly relieved when we were again under the roof of our hotel.

Many years afterward, Confederate Maj.-Gen. James J. Fagan, having, in the strange mutations of political events, allied himself with the Republican party and become the United States marshal for the Western District of Arkansas, described to me and others, among whom was my brother Judge William H. H. Clayton, a meeting of the original organization of the Ku Klux Klan in Memphis, held for the purpose of taking into consideration the question of my assassination by the Klan during 
my visit to Memphis. I do not recall any living witness to General Fagan's disclosures except my brother, who, in a letter addressed to me, January 9, I9I4, thus correctly described General Fagan's statement:

"In regard to the occurrence which took place at Memphis while you were Governor of Arkansas and went to that city, and while there with some of your friends attended the theatre, General Fagan told me that he himself was a member of the Ku Klux Klan and that he was at Memphis when you were there, and attended a large meeting of the Klan that was called for the purpose of taking into consideration your assassination; that at that meeting a resolution was offered directing a certain committee to proceed to take your life; that its adoption was warmly advocated by leading men, but that he, General Fagan, and other prominent members of the Klan made speeches against it, alleging that you deserved death, but that it was not expedient, as it would destroy the sympathy for the South that had been worked up by the Klan and Democratic Party of the South generally, during the late Presidential Campaign.

"That the ascendency of the National Democratic Party in the control of the general Government could only be had with the help of certain wavering Republican States of the North and West, and that they were finally prevailed upon to abandon the proposed assassination."

No one in Arkansas will doubt the veracity of General Fagan. My brother, Judge William H. H. Clayton, was for twelve years the United States District Attorney for the Western District of Arkansas, which included in its jurisdiction at that time the Indian Territory; for a period of eight years after separate courts were set up in Oklahoma he was one of the United States 
Judges in that Territory. His veracity will be questioned by no one who knows him personally or by reputation.

\section{MARTIAL LAIV IN CONWAY COUNTY}

Having described with as much brevity as possible the operations of the militia under the commands of Generals Catterson, Mallory, and Upham, I shall now describe martial law conditions and the operations of the militia in Conway County, which will complete the descriptions of the operations of martial law.

On December 8, I868, I issued a proclamation placing Conway County under martial law, and in my message to the General Assembly of December I4, announcing that fact, ${ }^{16}$ I referred but briefly to some of the events that caused my action. That the reader may judge of its justification, I shall now present to him a brief history of events not included in said message.

Having received reliable information of serious disorders at Lewisburg, Conway County, that had resulted in unauthorized action of private individuals in trespassing upon the rights of colored citizens by breaking up a court and seizing their arms, which were their personal property, I resolved, before resorting to forcible measures, first to give to the people of Conway County and the whole State an example of peaceful effort.

In furtherance of this policy, on August 28, I 868, I chartered the little steamer Hesper, and on my invitation the following prominent citizens of the State, representing both political parties, accompanied me to Lewisburg, the scene of the trouble: C. C. Scott; Hon. A. H. Garland; Hon. O. A. Hadley; S. L. Griffith; Col. Sandy Faulkner; Col. James Ryan; James Wolf, Esq.; S. H. Tucker; Col. W. S. Oliver, and the editor of the Little Rock Republican. 
That night we arrived at Lewisburg and I accepted the hospitality of Mr. R. T. Markham, who under the Johnson administration held the position of Deputy United States Marshal and who was a Democratic partisan. We were immediately interviewed by prominent citizens, who all assured us of the peaceful disposition of the citizens of Lewisburg and vicinity, but the following incident forced me to doubt the truth of their assertions. Our host, who had a bright little daughter about ten years old, in describing a meeting held the day previous to our arrival under the pretext of taking steps for the protection of the town against threatened negro aggression, had assured me that those attending this gathering had been absolutely unarmed. Another public meeting was called for the day after our arrival at io o'clock A. M. While the citizens in large numbers were passing down the main street in front of Mr. Markham's house to the meeting his little daughter looked out of the window and exclaimed: "Oh, Papa, the men haven't got their guns as they had the other day." I turned to Mr. Markham, whose face had flushed, and remarked, "Children and fools tell the truth." Then the subject was dropped.

I here incorporate a copy of my speech ${ }^{17}$ delivered at this meeting, - a speech that was based upon unquestioned previously ascertained facts:

"Fellow-Citizens: I have not come here in any partisan spirit, to stir up strife or to add fuel to the flames of discord that have threatened your county with such disastrous results. My mission is a peaceful one. I am here under the obligations of my office, to see that the laws are respected and enforced and that all persons who may be acting without authority of law desist and return peaceably to their homes. 
"It is not my present purpose to fix the responsibility for the outrages that have disgraced your county upon the guilty parties. This is properly for the courts to determine. I am here to turn aside, peacefully if I can, the disastrous results that must overtake the people if they permit such illegal and unauthorized proceedings to continue as have taken place in your midst within the past few days. What little I have to say I shall say plainly. I shall not cover up my meaning with honeyed words. I desire you to know the attitude I occupy toward you in my official capacity and to impress upon your minds the necessity of an obedience to the laws as they now exist. I had information that your county was in a state of insurrection. It seems that a few days ago such was the case. I am rejoiced to find that better counsels have prevailed. I am sure that if the people properly understood the motives and intentions of the State authorities no further trouble would exist. I am unwilling to believe that there is any considerable number of citizens who are disposed to set the law at naught and engage in armed hostility to the State Government. I trust that the outbreak can be traced to a few evil disposed and irresponsible persons, and that the great mass who have been engaged in it have been led through misapprehension to do that which a little cool reflection would have prevented. It seems that during the excitement, brought on by a few individuals, a very erroneous opinion was entertained that the colored people contemplated violence against the whites. Without investigating the facts, unauthorized persons proceeded to disarm the blacks, which at once led them to believe that the whites were disposed to commit outrages upon them. I cannot believe that the white people of this county are disposed to kill off the colored people; neither do I believe that the colored people ever contemplated for one moment the massacre of the whites. The history of the late war shows that the black man is not naturally bloodthirsty or revengeful; for did he not remain with and protect 
your families while you were fighting the battles of rebellion?

"You would have had no trouble if, instead of taking the law into your own hands, you had called upon the sheriff of the county for protection when you thought that the negroes were organizing to attack you. He could have gone clothed with the authority of the law, and the truth would at once have been made manifest, and all cause of trouble have been removed.

"Now I say to all, white and black, if you at any time apprehend danger, invoke the aid of the civil authorities. Look to them for protection,- - you pay them to perform that duty. It will not do for us to interpret the laws to suit ourselves, or to assume the authority of their execution. Such a course would lead to insurrection and perhaps to civil war. We must accept the laws as they are and not as we might wish them to be. A court of justice has been broken up by a mob, and one class of citizens has been disarmed by another. This is all wrong, illegal, and insurrectionary. That court must be reinstated and allowed to proceed. The right of the citizen to bear arms is a constitutional right,- - one that no citizen can be legally deprived of. The arms that have been illegally taken from the colored men must be returned to them. I have the assurance that it will be done. When you, my colored citizens, receive your arms again, use them as good citizens should. To white and black I say that armed assemblages are illegal; therefore, when you assemble for any purpose, do so peaceably and unarmed. If there is any person in this audience who does not recognize the fact that the colored man possesses the same rights, privileges, and immunities-civil and political-that the white man possesses, let him pause and reflect, for I say to him that such is the case, and the colored citizen shall be protected in those rights. I am informed that it has been charged that you are not to have a fair registration, and that this has caused bad feeling. Now, let me say a few words in regard to regis- 
tration. You shall have a fair registration, and a fair election too. When I say this I mean just what I say. Let no one misunderstand me,- the registration law shall be enforced. So far as my authority goes, every man who is entitled to register under the law shall be permitted to do so; and those who are disqualified shall not. It is not for me to say who can register and who cannot. The law fixes the qualifications of electors. I have no authority to interpret it to suit myself; neither have you. When the day of election arrives every citizen who is registered can vote in accordance with his own judgment. Those who are not registered cannot vote.

"I understand that the militia law is distasteful to some. I have only to say that it is a law that will be enforced. The militia force will be organized in this county and throughout the State. The organization of the militia does not inaugurate a new principle of government. It is as old as the Constitution itself. Every State has its militia. I am inclined to think that you do not understand this law. It is to preserve the peace and is only to be used when the civil authorities are unable to enforce the laws. To all good citizens, who are willing to obey the laws, the militia need give no alarm, but rather an assurance of safety. If there be any who intend to resist the execution of the law, they may well object to the militia. But I say to all that so long as the civil officers can enforce the law there will be no armed force called into service.

"And now in conclusion, I am for peace and I will exhaust all peaceful remedies to preserve order and execute the laws. When peaceful remedies fail then I will resort to force-but this must be the last resort.

"Let us have peace. Have we not suffered enough from war? We are just now recovering from its terrible effects. Providence has helped us with abundant crops, the lap of nature is full, her face is smiling, she invites us to stretch forth our hands and enjoy her rich gifts. Let us turn our whole attention to peaceful 
pursuits. Let us gather the harvests we have sown and build up our broken fortunes, and not by reason of our political differences plunge headlong into rebellion. For rest assured that if we sow the wind we may expect to reap the whirlwind. If the American people make political mistakes they will rectify them.

"Trust to peaceful remedies. Violent measures will accomplish nothing but ruin and desolation.

"I have brought with me Colonel Garland and other prominent citizens of Little Rock of both political parties. The Colonel and I disagree upon the political issues of the day, but I am happy to say that upon the questions of peace and the observance of the laws as they exist, we both stand upon the same platform. tion."

"He will address you. I thank you for your atten-

Before I left to return to Little Rock I had the assurances of the most prominent men of Conway County that no further unauthorized action upon the part of private citizens would be had, and that the arms taken from the negroes would be returned to them, which assurances were afterward practically disregarded.

The State Government had been in existence less than two months when this disturbance occurred. Had I then known what was afterward divulged to me by the "mysterious stranger," I would have had no parley with the Ku Klux of Conway County. This first effort at conciliation proved to be a mistaken policy, having been taken as an evidence of weakness on my part, and a fabric of lies was built upon it, among which was the charge of the Gazette, in its issue of August 28, I 868, that I had already started the negro militia to the scene of the disorder, and my pacific efforts were made the subject of ridicule.

To illustrate the mendacity of the Ku Klux Organ, 
soon after the breaking up of the court and the disarming of the negroes there it published a communication from a "reliable gentleman of Pope County, of the highest respectability,"-as the Gazette of August 28, I868, put it,-in which among other absolutely false statements appeared the following:

"The citizens of that place (Lewisburg) feeling insecure from known facts, and from reports constantly coming in, sent out $\mathrm{Mr}$. Thomas Burchfield and $\mathrm{Mr}$. George Bentley to ascertain the extent of the occasion of alarm and if possible to induce the parties (the negroes) who had assumed the hostile attitude to desist from the execution of their threats. Meanwhile some two or three hundred persons had assembled at Lewisburg, to defend the place if necessary. [The meeting referred to by Markham's little daughter.]

"Burchfield and Bentley left on their mission of peace

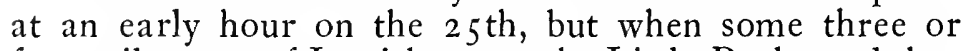
four miles east of Lewisburg on the Little Rock road they were suddenly fired upon by a party of nineteen negroes, the volley wounding Burchfield, it is said by his physician mortally, and killing Bentley's horse. Both of these gentlemen are old and reliable citizens of Conway County and undertook the mission of peace for the single purpose of bringing about a cessation of hostilities and to preserve the peace. ..."

In this connection I insert the following extract from a letter dated February II, I907, from the late Dr. A. D. Thomas to me. Dr. Thomas was a gentleman of the highest standing in business circles, and a brotherin-law of the "old and reliable citizen" George Bentley.

“... The Thomas Burchfield is probably the man who was killed between Lewisburg and Plummerville when the Ku Klux started out one night to make a raid on the negroes in that bottom. The negroes got wind of 
their coming and ambushed them, shooting this man in the bowels and scattering the balance of them. My brother-in-law, George Bentley, was with them, and came home minus the saddle on his horse and his hat, and told his mother that he was through with the $\mathrm{Ku}$ Klux. He was only I 7 years old at the time."

So it seems that the "mission of peace" these gentlemen engaged in was really a midnight raid of the $\mathrm{Ku}$ Klux upon a small squad of negroes who for once routed their oppressors and drove them from the scene in the utmost confusion. A ridiculous travesty upon $\mathrm{Ku}$ Klux chivalry!

The facts relating to this entire disturbance, as subsequently ascertained, clearly showed that it was the purpose of the $\mathrm{Ku}$ Klux in Conway County first to disarm the negroes and then, when they were in a helpless condition, by repressive and terrorizing acts, to cause them either to abstain from voting or to vote the Democratic ticket at the November election.

\section{INCENDIARY FIRES AT LEWISBURG}

Now came sudden information of a serious outbreak in Conway County, - an outbreak that I was able to meet with my eyes opened, and with information from sources on which I could fully rely.

About December 4, I 868 , I received information describing an incendiary fire at Lewisburg, of which, on December 7, I 868, the Republican published the following account:

"KU KLUX KILL ONE MAN AND BURN THE VILLAGE OF LEWISBURG

" . . From the evidence it appears that six $\mathrm{Ku}$ Klux, wishing to gain a little notoriety, assassinated a 
colored man about two miles north of Lewisburg, Wednesday night, December 2; and after committing the chivalrous act passed into town and succeeded in destroying by fire one-half of the village. They commenced operations by setting fire to Captain Matthews' Hotel which was destroyed, together with the Post Office building, storehouses, and dwellings. All the books, letters, and papers in the Post Office were lost. The men were disguised, but it is thought they can be identified, as being obliged to leave in a hurry they left behind them some important papers which may lead to their detection. . ."

This hotel belonged to two prominent Republicans, and it will be observed that the six men who set fire to it were disguised. The other buildings that were burned on account of their close proximity, so far as I know, were owned by Democrats, but that fact was evidently not taken into consideration by the incendiaries. Their disguises established their $\mathrm{Ku}$ Klux identity, for during the period covered by this work there never was an instance of Republicans using disguises to conceal their identity. The object of these reckless men was evidently to punish a political enemy.

On the I 5 th of the same month the Gazette published the following letter:

"Lewisburg, Ark., Dec. 4, i 868.

"EDiTORS GAZETTE: Yesterday morning about four o'clock Messrs. Gill and Matthews' hotel was discovered to be on fire, which was totally destroyed with its contents; also the storehouse of Burrow, Rankin \& Co. was destroyed with its contents, except some one thousand or fifteen hundred dollars' worth, and that was nearly ruined with the rain and mud. Our smoke-house with considerable bacon, pork, lard, molasses, etc., etc., was totally destroyed. The saloons of R. T. Markham and 


\section{CIVIL WAR, IN ARKANSAS}

Carroll \& Bertram, with nearly all their contents, were destroyed. Our dwelling house was saved by great exertion and work of the citizens. . . Messrs. Burrow, Rankin \& Co. and A. Gordon and lady hereby tender their heartfelt thanks to the citizens for their great exertion in saving our property.

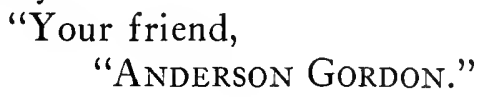

On December 6, I868, news came to me of the killing of Thomas Hooper. It was alleged that Hooper had been arrested by the militia on account of the murder of a negro by the Ku Klux in a midnight raid. The cap of one of the participants, having inside the name of Hooper, was knocked off and afterward picked up by the wife of the murdered negro. It was charged that Hooper, while a prisoner in the hands of the militia, two days before the declaration of martial law, was killed by some one of the militia, and an attempt was made to justify the act on the ground that it was done while the prisoner was trying to escape. The killing of Hooper, whether by the militia or not, furnished an additional reason for my declaration of martial law in Conway County.

The question may be asked: "Why did I not make the killing of Hooper the subject of an investigation by a military commission, as was done in other cases during the pendency of martial law?" My answer is that the civil authority had not been suspended there when Hooper was killed. The troops that were charged with this offense had not been called out by me, but were acting as a sheriff's posse. The matter was a local affair that came under the exclusive jurisdiction of the civil courts, which courts did take jurisdiction in the case by the arrest, trial, and acquittal of Captain Matthews and a colored man 
who were charged with the offense. Captain Matthews was subsequently murdered, but the particulars of his murder I am not able to give. For more complete information relative to the killing of Hooper I refer the reader to "The Contested Election Case of John M. Clayton vs. C. R. Breckinridge," on file in the Library of Congress, Washington, D. C., testimony of myself, pp. 539 to 542 and 556 to 559 ; testimony of R. F. Hooper, pp. $52 \mathrm{I}$ to 523 , and testimony of W. H. Hooper, p. 522 .

The killing of the negro by the Ku Klux raiders, followed by the murder of Hooper and the incendiary fire just described, were my justification for my declaration of martial law in Conway County on December 8 , I 868. About a week after martial law was declared these conditions were greatly aggravated by a second incendiary fire, which resulted in the destruction of the business houses of Breeden \& Casey and Howard \& Wells, and by the atrocious murder of James M. Casey of the first named firm, and his robbery of four or five hundred dollars, as near as I can remember, after which his body was left in the burning building to be destroyed by the flames.

On December 20, I 868, the Gazette gave an account of this second fire at Lewisburg, from which I quote as follows:

\section{"ANOTHER FIRE AT LEWISBURG}

" ... The following statement was made to us by a reliable citizen of Conway County, who is now in the city a refugee from home. It appears that on Wednesday night last, the I 6 th, about 8 o'clock, Gibbons, with four companies of militia, commanded respectively by Gray, Williams, Roane, and Matthews-the company commanded by the latter are negroes-entered the quiet little village with demoniacal yells, shooting in every direction, and marched up to the store of Messrs. Breeden 
$\&$ Casey, fired a number of shots through the door, and then set fire to the building by pouring out upon the floor a can of coal oil and setting it on fire. The flames rapidly spread and soon communicated to the storehouse of Messrs. Howard \& Wells which, together with the former, was entirely destroyed. Colonel Eagan's store adjoining was saved by the almost superhuman efforts of the citizens, through the use of wet blankets placed upon the roof. During the burning Mr. Casey, of the firm of Breeden \& Casey, was shot down by some one of the murderous villains, his pockets rifled of money, watch, etc., and his body thrown into the burning flames. His trunk was burst open and the entire contents appropriated. The militia, both white and black, while the fire was in progress consumed the time in rifling the buildings of their contents, reserving such articles as they desired for their own use, and burning such as could not be used. ...'

In contradiction of all the statements contained in the above article, I reproduce a communication from Capt. John J. Gibbons, commander of the militia stationed at Lewisburg, dated December 23, I 868, and published in the Republican, December 30 of that year, and a number of supporting affidavits:

\section{"Editor of the Republican.}

"Sir: I send you for publication in the Republican the particulars of a fire at Lewisburg on the night of the I6th of December, I868. The fire broke out and was first discovered in Messrs. Breeden, Billingly \& Co.'s storehouse, which was burned down, and also Howard \& Wells' store was totally destroyed by the fire.

"I make this statement to refute a slander published by the Gazette, in which it alleges that the information was obtained from 'a reliable citizen of Conway County who is now in this city a refugee from home.' 
"Ist. If that 'reliable citizen' is one E. W. Adams, he is not only a refugee, but also a fugitive from justice. "And if A. Gordon is the 'reliable citizen,' I will only refer to the affidavit of Lydia A. Gordon, his wife; James Gordon, his brother, and R. T. Markham and John Rankin, citizens of Lewisburg.

" $2 \mathrm{~d}$. The four companies, as alleged by the $G a$ zette, did not come to Lewisburg on Wednesday, the r6th instant.

"Captain Matthews' Company State Guards came to Lewisburg on Wednesday the 8th, and for their good conduct toward the citizens here I refer to the affidavits of John Rankin, R. T. Markham, and William Howard, all citizens of Lewisburg.

" 3 d. I came to Lewisburg on the I 4 th instant, with twenty-two men. Captains Gray and Roane came afterward. The 'demoniacal yells' of the four companies of militia were never heard by the cititzens of Lewisburg on the night of the 16 th; this is shown by the affidavits of John Rankin, James Gordon, and others.

"Nor was J. M. Casey murdered and robbed by the militia, and as to who is guilty of that outrage, see the copy of the verdict of Coroner's jury relating to the case.

"4th. "The superhuman exertions of the citizens of Lewisburg to arrest the fire' were aided by seventy-five militia men; see affidavits of John Rankin, Wells, William Howard, R. T. Markham, and Lydia Gordon.

"The militia, both white and black, 'while the fire was progressing' did all in their power to arrest and stop the fire, and were not 'rifling the buildings of their contents' as represented by the 'reliable citizen from Conway County.' For proof see sworn statement of William Howard, A. Wells, James Gordon, and others.

"The allegation that "the town is now occupied by the ruffians who perambulate the streets shooting and cursing' is not true, as shown by affidavits of Rankin, Gordon, Howard, Wells, and others.

"I would further request that the editors and pub- 
lishers of the Gazette disclose the name of the aforesaid 'reliable citizen of Conway County,' and show who is responsible for their malicious slanders.

\author{
"Respectfully, \\ "John J. Gibions, \\ "Capt. Commanding Conway County."
}

\title{
SUPPORTING AFFIDAVITS 18
}

"William Howard, a citizen of Lewisburg, being duly sworn, deposes and says : I am one of the firm of Howard \& Wells, merchants in this place; our house was burned on the I 6th of December, I 868 . I was not on the ground until the house had fallen in; there were 16 sacks of coffee, several bolts of calico and domestics, two barrels and about one-fourth of flour, some jeans, three trunks that had been taken out of our house. I did not see, hear, or know of any person plundering or pilfering.

"I know a great many of the troops that are stationed here; I believe them to be good citizens; never heard any threats made against any person or their property; never saw any person mistreated by them. I think nearly every person on the ground was militia, and they were all doing all they could to prevent as much as they could when I arrived. I have seen a printed report of the fire at this place on the 16 th of December, I 868 , which I denounce as a false and malicious slander, not only to the troops, but also to the citizens of this community.

"W. R. Howard, December 22, I 868."

"R. T. Markham, a citizen of Lewisburg, Ark., being duly sworn, deposes and says: I have never heard any of the militia that are stationed here at this place make any threats against any person or their property. I know nearly all of the militia here, and I believe them to be good citizens. There has been a guard near my house since the 17 th inst.; we have been respectfully treated by 
them, both black and white. I have been acquainted with Captain Gibbons a great many years and never knew him to mistreat anyone. I knew him during the war; don't believe he would suffer his troops to commit any outrages if he knew it. I have seen a printed report of the late fire at Lewisburg and denounce it as a malicious slander against the citizens of this community.

"R. T. Markham, December 22, i 868."

"John Rankin, a citizen of Lewisburg, Ark., being duly sworn; deposes and says: On the night of the I6th of December, I868, I was in our store, opposite Colonel Gordon's residence and about 40 yards from the storehouses that were burned. I was going from the warehouse with a lantern. I heard some men talking and laughing. They asked who that was with a light, and said put it out. I did not put it out; they seemed to be very merry. I thought it was some of the boys on a spree. If I were to see or hear persons going on purpose to burn a house or commit a robbery I don't think they would act like these men. I think it was about two hours after I heard these men that I heard the alarm of fire. I remained at our store some time after the fire broke out.

"I saw no person plundering or pilfering anything. The greater portion of the persons that assisted in trying to arrest the fire were persons belonging to the militia. I have not heard any threats either against persons or their property. I think the negro militia came here about a week before the fire, and I don't know of any outrage committed by them since they have been here.

"I think Captain Gibbons came about the I $4^{\text {th }}$ inst., with the white militia. I don't know how many he had with him. All the militia that I have noticed all take an interest in preserving the peace.

"Ever since the fire there has been a guard stationed near our house, and they have treated our folks respectfully all the time. I an acquainted with a great many of the militia and believe them to be good citizens; I 
have seen printed reports of the fire, and the acts of the militia at this place, which I denounce as a malicious slander.

"John Rankin, December 22, I868."

"James M. Gordon, a citizen of Lewisburg, Ark., being duly sworn, deposes and says that I have never heard any threats against any person or their property by the militia stationed at this place; on the night of the fire of the 16 th of December, I868, I got on the ground as soon as I could and assisted in stopping the fire; the greater portion of the men that were assisting belonged to the militia. I know a great many of the troops stationed here, and I consider them good citizens. Never saw any person on the night of the fire pilfering or plundering anything. I heard somebody say that they saw somebody taking off some coffee, but paid no attention to it. I think Captain Gibbons brought the negro militia here about one week before the fire; I don't know of outrages committed by the negroes.

"When Captain Gibbons came with the white militia they made no attempt to commit any outrages. I have known Captain Gibbons a great while, both before the war, during the same, and since; always received kind treatment from him; while he was in the Federal Army that was stationed at this place during the war I never knew of any person being mistreated by him.

"I have seen a printed report of the late fire at this place and denounce it as a malicious slander against the citizens of this community.

J. M. GoRDON, December 22, I868."

"W. L. Conley, a lieutenant in Captain Roan's Company of militia, who, being duly sworn, deposes and says that on the evening of the 16 th inst. he came into the town of Lewisburg in company with about 30 men of Captain Roan's company of militia; at the time the alarm of fire was given I was at Capt. J. J. Gibbons' 
Headquarters, and was ordered by him to take 50 men of the white militia and save all the property that I could, and if possible arrest the fire. I did so. The men came out promptly and acted nobly; by their exertions aided by some of the citizens, we succeeded in saving Colonel Eagan's dry-goods store, also D. B. Russell's drug-store, which otherwise would have been burned. After the fire had subsided I placed a guard on the goods we had succeeded in saving, to prevent any of them from being stolen; yet I saw very little of such disposition manifested. I have seen the Gazette's report of the reliable citizen of Conway County; I in common with all others present during the fire denounce him as a malicious liar. "W. L. Conley, December 22, I 868 ."

"A. C. Wells, a citizen of Perry County, Ark., lives across the river, opposite Lewisburg, Ark. On the night of the I6th of December, I 868 , my storehouse was burned down; when I got on the ground a great many of our goods had been taken out of the house; there were a great many of the militia present; they all showed a disposition to preserve all they could, and many of them assisted me to take care of our things; saw no person take anything whatever; I believe that it was by the aid of the militia that other houses were saved.

"I have seen a printed report of the late fire at Lewisburg, which I denounce as a false and malicious slander to the citizens of the community, and also to the troops that are stationed here, as they have acted as gentlemen as far as I know: never heard any threats by any person. “A. C. Wells, December 22, I 868."

"Lydia Ann Gordon, being duly sworn, deposes and says, that I have never been mistreated by any of the militia; on the night of the I6th of December, I 868 , some men came by our house hallooing and making a great noise; after they passed I heard four or five reports of pistols or guns; they acted like drunk men; as they came back, some one threw something at our dog on the porch; 
since the fire there has been a guard every night near our house; they have treated me and my family respectfully; the party that made the noise passed my house about six o'clock on the night of the 16 th inst.

"I first raised the alarm of fire about two hours after these men passed back. I live about 30 yards from the store that was burned. I did not see the men shooting; I saw a great many persons that were not citizens of the place assisting in trying to arrest the fire; I did not see any person plundering any thing that had been thrown out on the street. I have heard no firing on the street since the fire; a few moments before the discovery of the fire I heard a report of a gun or pistol which made a dead sound; I thought it was in the direction of the building that was destroyed. I knew Captain Gibbons during the rebellion and always received kind treatment from him, both to myself and family. From what I know of Captain Gibbons I don't think he would suffer his men to commit such outrages as the burning and robbing of the I6th inst.

"Lydia Ann Gordon, December 22, i 868."

This affidavit is especially significant in view of the fact that it is generally understood that it was upon her husband's statement that the Gazette based its article, published on pages I 54-I 55 .

In addition to Captain Gibbons' letter and the affidavits reproduced, the coroner's verdict on the death of James M. Casey fully disposes of these malicious falsehoods. I reproduce it from the Daily Republican, December 24, I 868 :

"State of ARKansas,

"County of Conway.

"Be it known that upon an inquisition begun on the I $7^{\text {th }}$ day of December, I868, at Lewisburg, Conway 
County, Arkansas, before L. B. Umphlet, one of the Justices of the Peace of said county, upon the view of the dead body of James M. Casey, by the oaths of James T. Young, William L. Brents, Thomas H. Harness, Thomas L. Wells, William Lloyd, Thomas A. Upchurch, William Choat, David A. Wells, William H. Roberts, John A. Ferguson, John M. Bond, and William A. Upchurch,-twelve good and lawful jurors of said county, - the said jurors being in due form sworn,- - do say that the said James M. Casey came to his death by being murdered for his money, in some manner unknown to this jury, and the house in which he was was set on fire and burned down on the night of the r6th day of December, I 868, in the town of Lewisburg, Ark., by the hands of one Pompey O. Breeden and one George Bentley.

"IN TESTINIONy whereof, As well the said Justice of the Peace as the said jurors, do hereunto respectively set their hands, this 2oth day of December, A. D. I 868.

"L. B. Umphlet, J. P.,

William Choat, David A. Wells, John A. Ferguson, John M. Bond, W. A. Upchurch,
James T. Young,

Wm. L. Brents,

T. H. Harness,

Thomas L. Wells,

Wm. Lloyd,

Thomas A. Upchurch,

W. H. Roberts."

"State of ARkansas,

"County of Conway.

"I certify that the foregoing is a true and correct transcript of the inquest held over the body of James M. Casey, and finished on the 2oth day of December, I 868 .

"Given under my hand this December 20, I 868.

$$
\text { "A. B. GAYLORD, }
$$

"County and Probate Justice of Conway County." 
This leaves nothing for me to explain except that the George Bentley mentioned in the Coroner's verdict is the same George Bentley who, according to the Gazette's authority, was one of the two "old and reliable" 19 citizens of Lewisburg who went upon the "mission of peace" which proved to be really a Ku Klux raid upon the negroes.

Upon the receipt by me of an official report from Captain Gibbons of the highly satisfactory conduct of the troops under his command and the quieting effect produced thereby, supported by sworn statements from the best citizens of Lewisburg of both political parties, I revoked martial law in the county of Conway, and so informed the General Assembly in my message to the Legislature on January I 2, I $869 .{ }^{20}$

\section{RESTORATION OF CIVIL AUTHORITY THROUGHOUT THE STATE}

On March 2 I, I 869, I informed the General Assembly by message of the revocation of martial law and the reëstablishment of the civil authority in Crittenden County. This important message I now quote in its entirety: ${ }^{21}$

"Mr. Speaker: I am instructed by His Excellency, the Governor, to inform your honorable body that he issued a proclamation restoring the civil authority in the county of Crittenden, to take effect upon the receipt thereof by the officer in charge of that sub-district. He has also directed that at the same time the prisoners held under military order shall be turned over to the civil authorities, and the small force on duty there shall be disbanded.

"With this action, the occupancy of counties by 
process of martial law ceases for the present throughout the State.

"It is believed that the civil authorities in every county lately under martial law, as well as in the other counties, are able to enforce the laws and arrest and punish all desperate characters.

"Repeated assurances have been received from the sheriffs and other officers in those counties that the people are not only willing but desirous to see a faithful and prompt administration of justice in their midst, and to bring all offenders to punishment. The feeling of terrorism and insecurity that existed so generally before the inauguration of martial law has almost entirely disappeared. Men guilty of the most flagrant violations of the law were permitted to run at large or, if arrested and brought to trial, were in very few cases found guilty and made to suffer punishment, on account of the terror they and their friends exercised in their respective communities, or from a diseased condition of public sentiment which, to a great extent, sympathized with acts of outlawry, especially upon the persons and property of political or personal opponents, and which, in many cases, rendered the administration of the civil law a farce and a mockery.

"This has given place to a more healthy spirit of determination on the part of the citizens to see the law enforced.

"A large number of desperate men who formerly were a terror to the citizens and officers of the law have either been killed or driven out of the State, and assurances have been given that those who were driven away will not be permitted to return.

"The Executive was informed that three desperadoes, formerly residents of Lafayette County, had returned to that county; but he is assured by the sheriff that this is not the case, and that if they should come back they can and they will be at once arrested and made to suffer the penalty of the law. 
"Letters are constantly being received from all parts of the State, and from citizens of all political parties, bearing cheerful evidence of the very marked improvement in their respective localities. Lawlessness has been checked or put an end to, and quiet, security, and good order are being enjoyed by all classes. During the last three months but five murders have been reported to the Executive, while during the preceding four months nearly two hundred murders and attempted assassinations were reported.

"A proclamation will soon be issued by the Executive proclaiming as outlaws all murderers and desperadoes who have yet eluded justice by fleeing from the State and directing all citizens or bodies of citizens to take them dead or alive, if they should attempt to return to the State. Some evils have resulted from the occupancy of counties by martial law to individuals in those counties, but these evils have to a great extent grown out of the adoption of a necessary but very severe remedy which, while it has been of very great good to communities and society at large, has fallen heavily upon some individuals. In some cases unauthorized bands of men, pretending to be militia forces, have committed depredations, robbing and plundering citizens indiscriminately, but this evil was checked and stopped altogether in the south and southwestern part of the State by an order from General Catterson, commanding that district, directing the citizens to shoot all men found in such bands acting without authority of the State Government; and still later by an order from the Commander-in-chief to the Sheriffs, directing them to hold all bodies of men passing through their counties who were not subject to military order.

"In this connection it is urged by the Executive that your honorable body establish a Court of Claims to adjudicate claims arising from the operations of the militia in counties under martial law, and for purchases and supplies in other counties. Said Court to sit for a suf- 
ficient period in each county where martial law has existed and holding a final settlement at the seat of Government, being empowered to examine and adjudicate in reference to all supplies taken by the quartermaster and subsistence department, so that those who are properly entitled may receive pay for supplies furnished."

DECISION OF THE UNITED STATES SUPREME COURT IN THE CASE OF TEXAS VS. WHITE

At the December term of the United States Supreme Court of I 868 that tribunal, in the case of Texas vs. White, rendered a decision declaring valid the Reconstruction Measures of Congress and the State Governments established thereunder. ${ }^{22}$ This decision placed the Democratic Party of Arkansas in the indefensible position of having waged a violent and bloody insurrection against the Government of an equal and co-ordinate State of the American Union.

How many lives would have been spared, how much untold suffering would have been avoided, and how much more rapidly the State would have prospered, had the Democratic leaders either awaited or sought the decision of the only tribunal that could settle the question, instead of resorting to the violent and insurrectionary proceedings I have described,- - proceedings that were based solely upon the opinion of their Party National Convention that "we regard the Reconstruction acts (so called) of Congress, as such, as usurpations and unconstitutional, revolutionary, and void." 23

A CHARITABLE VIEW OF THE OPERATIONS OF THE KU KLUX KLAN IN ARKANSAS

There can be no justification for the original organization of this anarchistic order, but as to the operations of its individual members in Arkansas I am moved by a 
spirit of fairness to say that we should give due consideration to the great difference that existed at the close of the Civil War between the conditions of the discharged Union soldiers and those of the Confederates. The former, with good money in their pockets and free transportation to their homes, by reason of the diversified industries of the North found all avenues of employment open to them, while the Confederates, on their return home, found themselves subject to the following conditions :

They had no money that could be anywhere used for the purchase of the necessaries of life. The labor in the cotton fields was almost exclusively supplied by the freedmen, generally based upon a scale of compensation barely sufficient for the support of themselves and their families. The fact that a very large percentage was unable to read and write excluded them from employment where such qualifications were absolutely essential. By reason of the non-existence in the South of the varied pursuits open to the Northern soldiers, many Confederates found themselves in a state of enforced idleness, with starvation staring them and their families in the face.

With the return of the Confederate Army came another class by no means to be overlooked,- - the male descendants of the slaveholders, so graphically described in the following article from the Gazette of January I 5, I 867 :

"Misfortunes, it is said, are 'blessings in disguise.' Certainly the disguise is often so complete that we fail to detect the blessing. It is eminently proper, however, that we should endeavor to extract from their bitterness all the lessons of utility and consolation which tend to our improvement and lessen their sting. 
"For many years before the war it was the custom of our large slave-owners to send their sons to school and college, and when their education was completed they were put to some profession, or possibly into some mercantile house, as a mere form, but were never taught to labor. Indeed, it was almost impossible to confine them to any settled business, but with the restlessness peculiar to idleness they were found roving from one to another of our cities, stopping at 'crack' hotels, visiting the theatres, race courses, and other places of fashionable amusement, always well dressed, and always, or nearly always, thoroughbred gentlemen.

"The 'Governor,' or the 'Old man' stayed at home, ran the plantation, 'bossed' the negroes, shipped the cotton, sold it, bought a few more 'hands,' and with the balance paid master 'Tom's' or 'Charlie's' debts. In time the 'Old man' was gathered to his fathers, and the boys, having married, divided the negroes and plantation and settled down to live as their fathers before them had lived.

"They never learned to trade or follow any useful pursuit, and their professional studies were carelessly pursued with no intention of ever applying them to practice. But often a succession of bad crops and a few security debts would involve the pater familias, and the plantation and negroes would be swallowed up like a landslide in the Mississippi River, and my lord 'Tom' or 'Charlie' would be thrown upon his own resources for a living. Possessed of a good education, fine address, and handsome person, but with no knowledge of business or business habits, the poor fellow's prospects would be gloomy indeed.

"How often have we seen young men of the South in whose veins flowed the proudest and best blood of our land become perfect wrecks under such circumstances!"

To restore the political supremacy of the slave-holding power was the purpose of the descendants of the old 
slave-holding aristocracy, and for the advancement of that purpose they employed the most violent and insurrectionary methods.

A CORRECTION OF A GENERAL MISCONCEPTION OF THE TRUE CAUSE OF SECESSION

Before proceeding further I deem this an appropriate place to call the attention of my readers to what I consider a general misconception of the true cause that produced secession and all that followed. Perhaps nine persons out of ten, especially in the North, would say it was the apprehensions of the slaveholders that they would lose their slave property and cause the social disturbances emancipation would entail. I have never asked a Northern man his opinion on this question that he did not express this view. Slavery unquestionably was a strong adjunct of almost predominating importance, and as handled by the Secessionists it served to consolidate the whole Southern people.

From the time of the compromise that led to the adoption of the Constitution of the United States down to the period of secession nearly a hundred years had elapsed, during which time the slaveholders had dominated absolutely the slaves under their control. Hence, it was perfectly natural that the spirit of domination should have grown with their growth and strengthened with their strength. They imbibed it, as it were, with their mothers' milk until they began to consider themselves as constituting a semi-lordship, superior to other classes of American citizens.

During the period of which I have spoken they dominated the Government of the United States and, of course, in their own States they were absolutely supreme. So inflated were they with the idea of their superiority that 
many of them actually believed that one Southern man could whip five "Yankees," and when their political power was about to be wrested from them they launched into secession for the purpose of establishing a Government which they could unquestionably control.

At the time of secession there was no considerable party in the United States that favored compulsory manumission of the slaves. Mr. Lincoln did not favor it, but favored an amendment to the Constitution providing for the gradual abolition of slavery, based upon the consent of the States where it existed, with full compensation for the aggregate value of the emancipated slaves. I refer the reader to his Annual Message to Congress, December I, I 862, published by authority of Congress in "Messages and Papers of the Presidents," Vol. VI, p. I36, as follows:

"Resolved by the Senate and House of Representatives of the United States of America, in Congress assembled (two-thirds of both Houses concurring), That the following articles be proposed to the legislatures (or conventions) of the several States as amendments to the Constitution of the United States, all or any of 'which articles, when ratified by three-fourths of the said legislatures (or conventions), to be valid as part or parts of the said Constitution, viz.:

"Art. - Every State wherein slavery now exists which shall abolish the same therein at any time or times before the Ist day of January, A. D. I900, shall receive compensation from the United States as follows, to wit :

"The President of the United States shall deliver to every such State bonds of the United States bearing interest at the rate of per cent per annum to an amount equal to the aggregate sum of - for each slave shown to have been therein by the Eighth Census of the United States, said bonds to be delivered 
to such State by instalments or in one parcel at the completion of the abolishment, accordingly as the same shall have been gradual or at one time within such State; and interest shall begin to run upon any such bonds only from the proper time of its delivery as aforesaid. Any State having received bonds as aforesaid and afterward reintroduced or tolerated slavery therein shall refund to the United States the bonds so received, or the value thereof, and all interest paid thereon.

"Art. - All slaves who shall have enjoyed actual freedom by the chances of the war at any time before the end of the rebellion shall be forever free; but all owners of such who shall not have been disloyal shall be compensated for them at the same rates as is provided for States adopting abolishment of slavery, but in such way that no slave shall be twice accounted for.

"Art. - . Congress may appropriate money and otherwise provide for colonizing free colored persons with their own consent at any place or places without the United States."

In this message, on page 137 , he used the following language:

"It is no less true for having been often said that the people of the South are not more responsible for the original introduction of this property than are the people of the North; and when it is remembered how unhesitatingly we all use cotton and sugar and share the profits of dealing in them, it may not be quite safe to say that the South has been more responsible than the North for its continuance. If, then, for a common object this property is to be sacrificed, is it not just that it be done at a common charge?"

The final emancipation of the slaves near the close of the war was a war measure, just as one would have liberated a large corral of Confederate horses so that 
they could not be used against you in an impending battle. It was not for the abolition of the slaves, but for the preservation of the Union, that the great mass of the Federal soldiers fought. So I believe we may conclude that the question of Southern political national supremacy, and not slavery, was the fundamental cause of secession.

The dangers that actually arose at the close of the war from the unemployed ex-Confederate soldiers were forecast with what proved to be almost prophetic vision by Gov. H. Flanigan in his letter to Judge J. J. Clendenin, one of the three Commissioners he had sent to confer with Gen. J. J. Reynolds, then commanding the District of Arkansas, upon a proposition which might be called "Flanigan's Plan of Reconstruction." $\mathrm{He}$ proposed to have all the Federal county officers serving under the "Murphy Government" recognized by himself, and all the Confederate county officers serving in the territory controlled by the Confederacy recognized by Reynolds. This combination of Federals and Confederates was, according to Flanigan's plan, to call a Constitutional Convention for the purpose of laying the foundation, by the adoption of the new constitution, for the reconstruction of the State.

The ulterior purposes of Governor Flanigan and his friends were too transparent to escape the watchful eye of General Reynolds. The plan revealed an amazing lack of comprehension upon the part of its devisers of the well-established fact that the loser in the great game of war, after it has been played to a finish, must manfully await the reckoning that is always sure to follow. It seems that Governor Flanigan supposed that with one hand he could lay aside the still smoking musket while with the other he could gather up the reins of government which he and his secession friends had snapped 
asunder and contemptuously cast aside some four years before.

From the letter referred to, dated May I9, I 865, I quote as follows: ${ }^{24}$

"The greatest danger to the quiet and safety of the country (as I suppose) will be from guerilla bands who may be recruited and held together under the pretense that they are defending a valid State Government which did represent a large majority of the people. We shall have many men who will be unfitted for the peaceful avocations of life, and whose morals will not restrain them from violence. An excuse to enlist such will in all probability be used, and although they cannot be troublesome to the United States, they can destroy the less settled parts of the country, unless prevented by all judicial means."

The situation of the returning Confederate soldiers, who were without money or the means of earning it, was indeed desperate, and doubtless drove many of them into the Ku Klux organization, where the disguises and the sworn obligations of the members to protect one another under any and all circumstances afforded them opportunities to indulge safely in brigandage and pillage.

\section{FOOTNOTES FOR CHAPTER VI}

${ }^{1}$ Arkansas House Journal, I 868-69, pp. 25-26.

${ }^{2}$ Federal War Records, Series I, Vol. 48, p. 627.

${ }^{3}$ War of Rebellion, 102, Series I, Vol. 48, p. 600.

${ }^{4}$ Federal War Records, Series I, Vol. 48, p. 632, letter from Asst. Adjt.-Gen. John Levering to Bvt. Maj.-Gen. F. Salomon, commanding First Division, Seventh Army Corps, post of Little Rock, dated May 27, I 865 .

${ }^{5}$ General Catterson's statement before Arkansas House of Representatives, January I4, I869; published by the Daily Republican, January $\mathrm{I} 5, \mathrm{I} 869$. 
${ }^{6}$ Pp. 99-I02.

${ }^{7}$ Daily Republican, September 4, 1868.

${ }^{8}$ Arkansas House Journal, 1868-69, pp. 226-227.

9 Arkansas House Journal, 1868-69, p. 408.

${ }^{10}$ Arkansas House Journal, I 868-69, pp. I 70-I 7 I.

11 Published in Arkansas Gazette, January 26, I869.

${ }^{12}$ Gen. R. G. Shaver, originator of the Ku Klux Klan in Arkansas, pp. 59-60.

${ }^{13}$ Record of War Department, 20 L, 69.

14 Report of Col. C. H. Smith, November 3, I 868, War Dept., Doc. No. 7-1467, S. A. G. O., I869.

${ }_{15}$ Published in Daily Republican, February 4, 1869.

${ }^{16}$ Arkansas House Journal, I 868-69, pp. I 73-I 74.

${ }_{17}$ Published in Daily Republican, September 2, 1868.

${ }^{18}$ All published in Daily Republican, December 30, I 868.

19 Pp. I 50-I 5 I.

${ }^{20}$ Arkansas House Journal, I868-69, pp. 226-227.

${ }^{21}$ Arkansas House Journal, I 868-69, pp. 732-3-4-5.

22 McPherson's "History of Reconstruction," p. 452.

${ }^{23}$ Eighth plank of Democratic National Convention, New York, I 868; McPherson's "History of Reconstruction," pp. 367368.

${ }^{24}$ Official War Records, Series I, Vol. 48, p. 629. 


\section{CHAPTER VII}

MARTIAL LAW IN THE COUNTIES OF CRITTENDEN AND CONWAY NOT PERMANENTLY EFFECTIVE

Of the thirteen counties in which martial law had been proclaimed subsequent events proved that eleven were permanently restored to lawful and peaceful conditions. Two were not-Crittenden and Conway. I deem it expedient to state in detail some of the events upon which I base this assertion, commencing with the county of Crittenden.

\section{MURDER OF CAPT. A. J. HAYNES}

On July I6, i 869 , C. N. Wilson, Justice of the Peace, wrote me as follows: 1

"To His Excellency Gov. Powell Clayton,

"SIR: I have the honor to submit the following report of perhaps the most brutal, cowardly, and atrocious murder 'of one more of the men whose only fault was a sincere desire to do his duty and obey the laws of the land' that has ever taken place within the limits of this State.

"Capt. A. J. Haynes was at 6:30 on yesterday shot in the back with buckshot by one Clarence Collier; there were two loads from a double-barrelled gun shot into him. The assassin then, with the fiendishness worthy of a demon, deliberately walked up to where the body of Haynes was lying and fired five more shots into it with an army revolver. 
"This was done in broad daylight and in the presence of three or four persons who made no attempt to stop the shooting, but looked on calmly and dispassionately.

"This murder was premeditated; the murderer had his horse ready, had his well-filled saddle bags slung over the saddle, and when through with his deed of blood he walked to his horse and got on. One of the men in front of the store where the shooting took place handed him his coat.

"I feel deeply this murder. I have been associated with Captain Haynes for years, both in and out of the army, and know him to be as honorable, straightforward a gentleman as it ever has been my good fortune to become acquainted with.

"There are to-day desperate characters scattered all through the county, and they mean mischief. Lives of other men have been threatened, and unless there is a vigorous enforcement of justice it is of no use for Union men to live in this county."

In this same connection I quote from a letter from Colonel E. M. Main, under date of February 5, I9 10, which reads as follows:

"On the departure of Colonel Watson with the Helena detachment of State troops, the Command of the Sub-military District, with the two Crittenden County companies, was turned over to me. From this time until civil law was restored and the troops disbanded, nothing of special interest transpired; our efforts being directed to the restoration of peace, harmonizing the discordant factions, and restoring confidence, with, however, but partial success. The unbridled passions in the absence of law had inflicted wounds that only time could heal. The seeds of discord and strife had been sown and a bitter harvest must inevitably follow-and Captain Haynes paid the price with his life. He was shot from behind in the back. I had previously left the county." 
The day thereafter the Memphis Post published the following account of the assassination: ${ }^{2}$

\section{"DASTARDLY ASSASSINATION}

"Another of those most dastardly assassinations of ex-United States officers by rebel desperadoes which have blackened the history of the South so many times since the War occurred last evening at about half past six o'clock, at the little town of Marion, the capital of Crittenden County, Ark., which lies across the Mississippi from Memphis. Capt. A. J. Haynes, formerly a gallant officer of the Third Colored Cavalry, was shot in the back and instantly killed, without a word of warning, by Clarence Collier. It appears that Captain Haynes had just returned from a trip to Memphis, had stepped out of the hack which runs from Mound City to Marion, dropped into Justice Wilson's office for a moment, and started to walk to his place, a mile or a mile and a half distant. On the best terms with all the citizens of the county, he had no apprehensions of danger. He had, however, barely turned the corner of Mrs. McAllister's when Collier, who had apparently been lying in wait for him, came out from a grocery on the opposite corner of the street. Haynes was leaving, and without a word of warning Collier drew a bead upon him with a double-barrelled shotgun and fired. The charge took effect in Captain Haynes' left side. The assassin instantly discharged the contents of the second barrel into his back. The Captain fell upon his face a corpse. But the vengeance of the brutal fiend was not satisfied. He advanced toward his prostrate victim and emptied his revolver into his dead body, riddling it with balls. Two lodged in his head. The assassin coolly returned to the grocery whence he issued to do his bloody work, received his coat, it is said, from the hands of Gilbert Dowell, mounted a horse, evidently prepared for the occasion, and rode out of town undisturbed. It is reported that besides Dowell, 
John McClung and Captain Chick were in or about the grocery referred to during the assassination. These men are also reported as having left the town as soon as the excitement began to spread. The citizens rushed out on hearing the reports of the shotgun and pistol, but had not recovered from their consternation ere the assassin was beyond their reach. The colored people who were warmly attached to Captain Haynes, some of whom had served with him in the army, frenzied with rage, seized any arms at hand, mounted themselves as best they could and followed the trail of the murderer. They were out all night and are still hunting him in the cane-brake in the southern part of the county. The sheriff gathered a posse, armed them, mounted them, and started for the river, expecting that Collier would attempt to effect a crossing to this side of the Mississippi. The county is on the alert and apparently sincere in its determination that the cold-blooded murderer shall not go unpunished. Parties from Jones' Landing, a small place about twenty-five miles below Memphis, on the Arkansas shore, report Collier as passing there on a jaded horse about ten o'clock last night.

"Clarence Collier, the assassin, is a young man about twenty-one years of age, slim build, weighing about one hundred and thirty-five pounds, with black hair, dark eyebrows, and a small dark mustache. As young as he is, it is said that he has killed no less than five men. It will be remembered that young Bethel, a son of our wellknown citizen, R. C. Bethel, was killed by him a year or so ago. We are informed that Haynes and Collier had never had any hard words. Collier, having been connected with the $\mathrm{Ku}$ Klux, as alleged, fled from the county; when the militia left he returned and assured Haynes that he had returned to live peaceably with all men. The relations between them are understood to have been of an entirely friendly character. Indeed, we are assured that Captain Haynes was living on apparently the most friendly terms with all the citizens of the county. 
He interfered with no one, and since the advent of the militia was molested or threatened by no one."

To show the vindictive spirit and mendacity of the anti-reconstruction newspapers of Memphis, Tenn., I quote as follows from the Memphis Appeal, of July I 7, I $869:^{3}$

"About half past five o'clock Thursday evening a rencontre occurred on Front Street, Marion, Ark., between Captain Haynes, the late infamous commander of Clayton's militia, and Clarence Collier, which resulted in the death of Haynes. The affair is thus described by an eye witness:

"Collier was in McClung's grocery, where he had previously left his double-barrelled gun. He had been fishing in the morning and had not caught any fish, and expressed a determination to go squirrel hunting. Taking his gun, which had been loaded with buckshot for some time, he started out of the grocery and walked toward his horse, which was hitched a short distance off, remarking as he did so, that if he "could not catch any fish he intended to have some squirrels.' $\mathrm{He}$ had hardly said that when he encountered Haynes, who was walking down the street. As soon as Haynes saw him he stopped and put his hand behind him as if to draw a pistol, a habit of his, by the way, whenever he met any young men, several of whom (and Clarence among the number) he had recently threatened to shoot at sight. As soon as he observed this motion of Haynes', Clarence dropped his gun to a level and fired, pouring a load of buckshot into his left side. Haynes did not fall, although terribly wounded, but turned and faced Collier,-still attempting to draw his pistol. As he did so Collier poured the other load of buckshot into his breast and body, and he fell to the earth calling for help. Collier, on this, took his gun, which was now empty, in his left hand, and drew his pistol, being five or six paces from Haynes, and 
fired one shot at him, the ball taking effect in his body. $\mathrm{He}$ cocked his weapon again and levelled it at his victim, but the cap snapped. A second attempt was, however, more successful, and the pistol exploded, the ball striking Haynes in the head and producing instant death.

"Collier, after assuring himself that he had finished Haynes, put up his pistol and remarked, as if to himself, 'You, Haynes, will draw a pistol on me again, may be!' then walked deliberately to his horse, mounted him, and rode off.

"The affair produced the most intense excitement in Marion, and the news of Haynes' death spread like wildfire, especially among the negroes. In a few minutes Marion was full of an infuriated mob of them, who vowed vengeance against not only Collier, but all the young men of his acquaintance, especially McClung, Dowell, and Bellows, who were with him previous to the shooting. Squads of them, heavily armed and mounted, set off in pursuit of him and scoured the country for miles, visiting every house and hut, but up to noon yesterday they had failed to find him.

"The steamer Cheek, on landing at Apperson's place, some miles below the city, night before last was boarded by one of these parties, and not until her officers assured them in the most solemn manner that Collier was not aboard would they allow her to proceed on her way.

"A gang of these who remained in Marion, drunk with whiskey and excitement, burst open Rice's store, ostensibly to search for some of the young men. Not finding them they gutted the house of everything portable, amounting to about $\$$ I 500 or $\$ 2000$ worth of groceries and dry-goods. After cleaning it out they set fire to it and left. Fortunately the flames were discovered in time to put them out.

"Another gang went to the house of McPeak, where there were young people sitting up with the corpse of his daughter. They clattered up to it in a most boisterous manner, and when they stopped at the gate they fired a 
volley into the house. Two young men who were present took to the woods, and we understand made their way safely to the city yesterday.

"We learned yesterday evening that a perfect reign of terror existed in the country around Marion, and that all sorts of excesses were dreaded. We were informed that one of the roving squads of negroes caught a white man near Mound City about I I A. M. yesterday and whipped him nearly to death.

"LATER.-Since writing the above we learn that the police of this city yesterday evening arrested a $\mathrm{Mr}$. J. $T$. Bellows (one of the gentlemen whom the negro mob compelled to flee from Marion as detailed above) on the charge of being accessory to the 'murder,' as they are pleased to term the killing. He was confined in the Adams Street station. As soon as his arrest was made known to Colonel Lysle, of the law firm of Brown \& Lysle, he immediately made efforts to obtain a writ of habeas corpus. Late in the evening a warrant was issued for Bellows from Squire Foley's office, and he was sent to jail to await an examination, which will take place this morning."

From the Memphis Ledger I quote as follows:

"Gallant Clarence Collier! The blessings of an oppressed people go with you, and whenever the clouds lift you shall be known and honored throughout the lands as the William Tell of Crittenden County, Arkansas."

In vindication of the character of Captain Haynes I reproduce a communication from twenty-nine reputable citizens of Crittenden County, - of both political parties, six of whom were officials, - addressed to the Memphis Appeal, in answer to that paper's false account of the murder of Captain Haynes and their vicious attack on his character: 


\section{"EDITORS OF THE APPEAL,}

"GENTLEMEN: We, householders and property owners of this county, respectfully ask leave to present a few facts and suggestions for your consideration. Your strictures on the death of Captain Haynes are totally at variance with the facts, and are producing in this county a bad state of feeling. We want peace, quietness, and order; and we ask you, for God's sake, to desist in the publication of such articles as lately appeared in the columns of your paper in reference to this matter.

"We deplore the death of Captain Haynes and especially so the manner in which it was committed. The man Collier, who so foully assassinated him, was a desperate and lawless character, - an ulcer on the community, - while, on the contrary, Haynes, no matter what his politics may have been, - and many of us differed honestly with him,- - has done more, or as much, to serve and advance the material interests of this county as any man in it. Though a prejudiced man, he was earnest, hard-working, and honest, and as a friend and a neighbor Captain Haynes was equal to any. He was foully murdered. 'The verdict of the coroner's jury and the examination of the body by the physcian, Dr. T. C. Whitsett, all serve to establish the fact that he was shot in the side and back without a moment's warning. It was a deliberate, cold, and brutal murder." 4

As to the character of Clarence Collier, he was at the time of this murder a fugitive from justice on account of the murder of George J. Bethel, and for his apprehension and conviction I had previously issued a reward of $\$ 500$.

Some of the prominent Memphis newspapers, outrage machines, ground out from day to day, principally for Northern consumption, accounts of outrages in Crittenden County, nearly all of which were pure fabrication. Even the Gasette, with all its unfairness, found it 
necessary in its issue of January 26, I 870 , to call a halt upon one of these disseminators of false information, the Memphis Appeal, in the following language:

"Crittenden. The following accounts of outrages in this county are condensed from the Memphis Appeal's sensational accounts, many objectionable statements being suppressed. We could wish that our esteemed contemporary would put a curb on its reporters in their recital of events transpiring in Arkansas. While highly varnished reports may have a tendency to make a paper sell, we opine that a true statement of facts would render the reader much more capable of forming his opinion as to the condition of things in Arkansas; and we respectfully submit that the Appeal is doing our State a great injury, unintentionally, by giving currency to reports such as appear in its issue of the I 8 th of January."

Observe, too, the following extract from the Helena Clarion of July 29, I 870 , a conservative newspaper with Democratic proclivities:

"There is no doubt but that many of the outrages we hear spoken of never occurred. Most of the readers of the Monitor remember that that paper asked of the Memphis papers that they should stop their accounts of outrages committed by the militia, as the men upon whom they stated the outrages were committed were not in the county of Crittenden. Some had been dead for years, some had moved away long ago, and others never had been there. These papers got hold of some five or six names, and they have the poor fellows murdered almost every day, and in the most horrible manner, when there are no such men in existence."

I considered the close proximity to Memphis, Tenn., the headquarters of the Ku Klux Klan of the South, and the violent and virulent sentiments existing there as the 
cause of the continuing lawlessness in Crittenden County. To have prevented such pernicious effects would have required the permanent occupation of that county by a military force, which remedy I regarded as impracticable.

The virulence of the diseased condition in Crittenden County was still manifest some twenty years later. In I 886 the Republicans in that County had a majority of I,346. They could easily have elected a complete Republican ticket, but in order to preserve friendly relations with the Democrats, who were then in power, they agreed upon a compromise ticket, which gave to the Democrats the important offices of sheriff and treasurer and some minor offices, and the balance of the ticket to the Republicans. This ticket was elected without opposition.

This arrangement continued until the election two years thereafter, when, without any notice whatever, the Republicans thus elected were confronted by a body of armed men, and they and about twenty other leading Republicans were driven from the county. I know that those officers and citizens remained in exile for a number of years. Whether or not they were ever allowed to return I am unable to say. These facts were stated by me in a speech delivered to a large gathering at the State House in Little Rock, and were never denied.

In the argument of Clifton R. Breckinridge before the Congressional Investigating Committee in the case of Clayton vs. Breckinridge, after speaking of the feuds that sometimes grow out of family grievances, he said: "Judge Cate told me, and I, of course, have no hesitation in stating it, that when General Clayton was in Crittenden County it took the earnest efforts of conservative citizens to keep men who were exasperated in this way from killing him." 
I suppose the instance referred to by Judge Cate was the following: In 1889 Colonel Featherstone was a candidate for Congress on a joint Republican and Union Labor ticket. I had promised him that I would try to get the colored vote in Crittenden County in line for him, which was very important if he were to be successful.

For that purpose I went to Marion, Crittenden County, accompanied by Colonel Featherstone and another gentleman, where I addressed a political gathering.

As I had intended to leave there on the night train, I had left my grip at the Marion depot. However, some time before the train was due I was secretly warned by a friend, who was also a Ku Klux, that the Klan had met and passed a verdict of death upon me and that it was to be carried into execution that night when I attempted to board the train.

In casting around for a means of escape I remembered that about three miles south of Marion there was a small railroad station that was seldom used by the Marion people. I concluded to go there and, if possible, take a train at that point. Accordingly I went to the Marion depot to obtain my grip.

While there I learned from the ticket agent that the train I had intended to take was five hours late, which would make it arrive at Marion about midnight. It was that fact alone that saved my life, for the Klan had evidently learned of it also, and as they felt that they had me securely trapped they relaxed their vigilance.

Therefore, without attracting their attention, I got a bright-eyed little boy to carry my grip and under cover of night we started on foot for the small railroad station outside of Marion. The road lay through dense woods, but fortunately we did not meet a single human being. When we arrived I found that the small waiting room 
was full of people, but as it was dimly lighted by a single oil lamp in the ticket agent's window I was able to slide into a dark corner unobserved. There I remained until the train came and as it was lighted in the same way I entered and obtained a scat without being recognized by anyone.

The train was westbound. I had an engagement to speak the next day near the foot of the mountains, where I arrived in safety and where I filled my appointment surrounded by friends.

\section{NOW COME TO CONWAY COUNTY}

Martial law in Conway County existed only for a period of about two weeks. When revoked its work had not been fully performed. The criminal class that had made martial law necessary was still extant, sowing the seeds which eighteen years later brought forth their pernicious growth.

I regretfully admit that a more searching exercise of martial law in this county might have prevented the disorders and series of crimes that culminated in I 889 in the assassination at Plummerville, Conway County, of my brother, John M. Clayton, while he was taking testimony in the contested election case of Clayton vs. Breckinridge.

Although about twenty-five years have elapsed since this monstrous crime was perpetrated, I do not feel that I am the proper person to present a detailed account of it. I shall, therefore, confine myself to a description of the conditions existing in Conway County which led up to it, and shall present some observations concerning the false pretexts that were invented to disguise its political character. 
CONGRESSIONAL ELECTION OF I 888 , SECOND DISTRICT

In the year I 888 an election was held for the Second Congressional District, which included Conway County. Clifton R. Breckinridge was the Democratic candidate for Congress and John M. Clayton the Republican. In the voting precinct of Howard, which included the town of Plummerville, Conway County, the following fraudulent and illegal proceedings occurred which culminated in the assassination of John M. Clayton on the 29th of January, I 889 .

The regular judges at this election were T. C. Hervey, Ransom Hayes, and Enoch Armstead. After spending some time in procuring a place to hold the election, which was finally held in the old McClure house, Hervey, with the two other judges present, declared that the polls were to be opened. Objections based upon the alleged irregularity of Hervey's appointment were raised as to his right to serve, and the matter was submitted to the bystanders by Enoch Armstead, one of the judges. On an affirmative vote Hervey's election was ratified and he served throughout the election. After this question was settled Hervey arose and said: "Boys, you tried to keep me out, and now I will keep you out, and I nominate Bill Palmer and W. T. Hobbs, and all that's in favor of Mr. Palmer and Mr. Hobbs being elected as judges say 'aye'." Without putting the negative vote, he declared Palmer and Hobbs elected, sent for a justice of the peace, and they were sworn in. Whereupon the two regular judges, who had thus been excluded, attempted to open a poll elsewhere, but were prevented from doing so by Charles C. Reed and James Lucas, two Democratic deputy sheriffs who lived at Morrillton and who, on the day of the election at Plummerville, under the instructions of the usurping judges, went down 
to where the two Republican judges were preparing to open the polls and prevented them from doing so under threat of imprisonment. ${ }^{5}$

For this act these two deputy sheriffs were indicted and convicted in the United States Court. Hervey, Hobbs, and Palmer were indicted by the United States Court for interfering with the regular judges of election, which resulted in the conviction of Hervey and the discharge of Hobbs and Palmer. ${ }^{6}$

After the close of the election held by Hervey, Hobbs, and Palmer, Hervey, accompanied by the United States Supervisor, Charles Wahl, carried the ballot-box around to different places, returning later to the polling place, where they found awaiting them Hobbs, one of the judges, and Bowdrie, one of the clerks. For the alleged purpose of getting more stationery and light, Hervey absented himself; but at Wahl's request he left the ballotbox with Hobbs and Bowdrie, remarking as he went out that if anything happened to the box he would not be responsible. ${ }^{7}$

He did not return within a reasonable time; so Bowdrie, for the alleged purpose of looking for him, also left. A few minutes after Bowdrie left some one came to the door whom Wahl believed to have been Ollie Bentley, the deputy sheriff, and asked if the counting had been commenced. Upon Wahl's replying that it had not, the man at once left. Immediately after this inquiry was made, four masked men with revolvers entered through the same door, one of whom grabbed the ballotbox and poll book, which were lying upon a counter, and exclaimed: "God damn you, we'll show you how Conway County goes," and another said to Hobbs, "Give us them papers and that damn quick," whereupon two of them, with their weapons pointing toward the judges, 
walked out backward with the ballot box and poll book in their possession, leaving the other two behind to cover their retreat. These remaining two, after seeing the theft accomplished, also backed out of the room in the same manner. ${ }^{8}$

The entrance of the masked men immediately after Bentley's inquiry as to the counting of the votes makes it almost certain that he must have seen them, which would have made it his duty as deputy sheriff to have arrested them.

THE ATTEMPTED ASSASSINATION OF UNITED STATES SUPERVISOR, CHARLES WAHL

On the I6th of December, I 888 , about one month after the above occurrences, while Charles Wahl and others were engaged in a game of cards at Dr. Bradley's office in Plummerville, Wahl was shot through a glass door. The ball cut a piece off of one ear and came out at the back part of his neck, leaving a deep gash. ${ }^{9}$

The reader will naturally ask: What was the motive for the attempted assassination of Charles Wahl? It was the knowledge that he possessed as to the illegality of the election, including his belief that Deputy Sheriff Bentley was the man who had asked the question about the counting of the votes, which might all be made the subject of a judicial investigation before the United States Court, and consequently endanger the unravelling of the whole infamous proceedings.

This view is sustained by Bentley's testimony before the Congressional Investigating Committee. When he was asked by this Committee as to his motives in desiring a compromise which would terminate the contest proceedings by giving to John M. Clayton all the votes he was entitled to, he testified as follows: ${ }^{10}$ 
"Q. What induced you to make that proposition to Coblentz, if you made it at all?"

"A. My dread of trouble and getting into the Court down here." (In Little Rock.)

"Q. Why did you have a dread of trouble with this Court?"

"A. Because I heard that Charlie Wahl had said he had seen me down there (Plummerville) that night."

"Q. Had any charges been preferred against you?"

"A. No, sir. No other than rumors, and it was rumored that I was connected with the affair."

The attempt upon Wahl's life made such an impression on him that he left the county, not again to return. The failure to stop his mouth by the assassin's bullet left nothing open to Deputy Sheriff Bentley and his confederates but to stop the contest proceedings, - - so full of disgrace and peril to the Democratic party of Conway County,-by the assassination of John M. Clayton.

Every consideration of decency on the part of Clifton R. Breckinridge, who was personally so deeply interested in the outcome of the contest proceedings, demanded a dignified non-interference with the actions of the authorities in the investigation of the assassination of John M. Clayton. Instead, from the testimony of Governor Eagle and from Mr. Breckinridge's own statement it would appear that he was in charge of the whole procedure.

If he had wished to render any assistance he should have suggested coöperating with me and my brothers. This he did not do and no message of condolence was received by any of us from him. Indeed, his hatred for me was so intense that every theory he devised was based upon the supposed antagonism of the assassin to me, and he labored to give the impression that my administration 
of the affairs of the State had been such that it was a sufficient reason for this atrocious murder.

$\mathrm{He}$ spent two or three weeks in Washington devising and spreading the theory that the murder was not political, but a case of mistaken identity on the part of the murderer, who, according to $\mathrm{Mr}$. Breckinridge, had thought that he was killing me. After this theory had been industriously circulated by Mr. Breckinridge and his friends he was forced to abandon it on account of the lack of one iota of sustaining testimony.

But this failure did not discourage him and he immediately fell headlong upon another theory which, he announced in Washington, when investigated would make the matter "as clear as the noon-day sun." This story was that John M. Clayton had been murdered by Thomas Hooper, a resident of California, in revenge for the killing of his father by "Clayton's militia."

Upon this theory Mr. Breckinridge frequently consulted with Governor Eagle and with Carroll Armstrong, the Chairman of the Democratic Committee of Conway County. Governor Eagle's investigation of this version was very limited, but it was sufficient to show the falseness of this surmise, as it was proved that the party accused of the murder had been bed-ridden for over a year previous to the murder. Even Mr. Breckinridge was forced to acknowledge before the Investigating Committee that "the Hoopers had nothing to do with it, let us admit that, and that disposes of all suspicions relating to the militia troubles." But that did not end his evidences of malignity toward me and at every opportunity he continued to bring in irrelevant matter which he thought would reflect on me.

If the testimony of Governor Eagle and the statements of Mr. Breckinridge are carefully considered it at once becomes apparent that the only theories investigated 
by them were the long distance ones. If the time spent on the far-fetched California theory had been devoted to an investigation of the affairs directly under their noses that called for prompt and vigorous action and which they ignored, it probably would have resulted in the detection of the murderer.

For instance, many people believed at the time and still believe that the murderer of John M. Clayton was a convict in the Zeb Ward convict coal mine, who was hired with money and the promise of liberty to commit the murder. Yet this very possible theory received no investigation from these two busy gentlemen.

Every man in Arkansas who was living there when this murder was committed will remember the great parade that was made by $\mathrm{Mr}$. Breckinridge and his friends about the immense amount of money they had contributed to enable the Governor to increase his reward and to assist Mr. Breckinridge in bringing the murderer to justice. These false reports were circulated through the newspapers and in every available way and went all over the country. The fact is that very few subscriptions were promised by them and the Governor's increased reward was unavailable because of the condition that the criminal must be convicted before payment would be made.

To show conclusively the falseness of their pretended liberality, Governor Eagle testified before the Investigating Committee that he had no money he could use in tracing clues to the murder. ${ }^{2}$ To meet this condition $\mathrm{Mr}$. Breckinridge supplied the Governor with the munificent sum of $\$ 100,{ }^{13}$ and the record shows that he promised the Governor all the money he needed, even to the extent of \$IO,OOO, which Mr. Breckinridge said he would raise by personal appeals from the stump. ${ }^{14}$ This, however, proved to be only another evidence of ineffective officiousness and Democratic duplicity, and with the ex- 
ception of $\$ 250$ of other people's money the Governor received nothing from Mr. Breckinridge or his friends but the \$IOO I have mentioned.

He attempts to show that more money was subscribed than was needed and cites a letter showing the return of certain moneys by me to the persons who had donated it. It is a fact that the money was returned, but it was received too late to be used beneficially, and Mr. Breckinridge and his friends had no part in the contribution.

My brothers and I had become convinced of the futility of further effort, so we discharged our detectives and returned to our friends the unused moneys subscribed by them, and the matter was left in the hands of the Almighty.

\section{FOOTNOTES FOR CHAPTER VII}

${ }^{1}$ Published in Daily Republican, July 24, I869.

${ }^{2}$ Published in Daily Republican, July 21, I 869.

${ }^{3}$ Republished by Arkansas Gazette, July 20, 1869.

${ }^{4}$ Republished in Daily Republican, July 28, I869.

${ }^{5}$ Testimony of Charles Wahl, contested election case of Clayton vs. Breckinridge, pp. 344-345.

${ }^{6}$ Contested election case of Clayton vs. Breckinridge, p. 582.

${ }^{7}$ Testimony of Charles Wahl, contested election case of Clayton vs. Breckinridge, pp. 345-346.

${ }^{8}$ Testimony of Charles Wahl, contested election case of Clayton vs. Breckinridge, p. 346 .

${ }^{2}$ Testimony of Charles Wahl, contested election case of Clayton vs. Breckinridge, p. 347.

${ }^{10}$ Contested election case of Clayton vs. Breckinridge, p. 29 I.

${ }^{11}$ Argument of C. R. Breckinridge, contested election case of Clayton vs. Breckinridge, p. 3 I.

${ }^{12}$ Contested election case of Clayton vs. Breckinridge, p. 320 - "I had no means in my hands that I felt authorized to use to hire men to go about and look after it and all I could do was simply to offer a reward." Pp. 559-560- "I have found nowhere where the contingent fund had been used as a detective 
fund. In the case when this clue was found in the upper part of the State, I had no money and I couldn't use the contingent fund. I had no means to send anyone."

${ }^{13}$ Contested election case of Clayton vs. Breckinridge, p. 560 -Governor Eagle: "I took that letter to Colonel Breckinridge and he gave me \$Ioo to apply on that object." Contested election case of Clayton vs. Breckinridge, argument of Mr. Breckinridge, p. I3- "I gave the Governor some money, I gave him $\$ 100$ and asked him to use it in following up this clue."

${ }^{14}$ Contested election case of Clayton vs. Breckinridge, argument of Mr. Breckinridge, p. I5-"I told the Governor of my expected absence and asked him to estimate what amount of money he would like to have before I left to meet any contingencies during the summer. I told him not to restrict himself, for I would take the stump before leaving and raise him in the Second District alone any sum he would say he needed, whether it be $\$ \mathrm{I}, 000, \$ 5,000$, or $\$ 10,000 . "$ 


\section{CHAPTER VIII}

PEACE AND PROSPERITY PRODUCED BY MARTIAL LAW

Martial law having been revoked, the question now naturally follows: What were its general effects, not only upon the counties subjected to it, but, with the exceptions referred to, upon the entire State?

On November 26, I 868, twenty-one days after martial law had been declared, the following call was issued "To the Democracy of the State of Arkansas" for a mass-meeting or convention to be held in Little Rock on January 8, r 869, signed by Robert A. Howard, Chairman of the State Democratic Committee, and twentynine other prominent Democrats : ${ }^{1}$

"The present state of political affairs in Arkansas being such as to suggest a fear of anarchy and bloodshed, and feeling assured that the Democracy of the State, constituting an overwhelming majority of her white citizens, desire peace and quiet and a fair, just, and economical administration of the state government, and admitting that a decent respect for the opinions of others, as well as justice to ourselves, suggests that we should give some public expression of our sentiments and an avowal of our purposes and desires in the present emergency, the undersigned invite a mass meeting of the Democracy of Arkansas at the city of Little Rock, on Friday, the 8th day of January, I 869."

Evidently when this call was made it was expected that the assembling of the convention would be in the 
midst of great public turmoil, but the events that had intervened between the call and the date of the meeting were such as to convince the Democratic masses that such a convention was unnecessary; hence, for lack of delegates, no convention was held. The Gazette in reference to this failure used the following language: ${ }^{2}$

"We note a few delegates in the city, but the representation is by no means general. We are not apprised as yet what their action will be, but shall report it in full when the convention shall assemble."

The convention never assembled, and this failure, I believe, clearly showed that the Democratic masses at that time were content with the results of the operations of martial law and opposed to any further attempt to overthrow the state government by Ku Klux methods. That they were dissatisfied and tired of being "led around by the nose" by the party organ and its coterie of $\mathrm{Ku}$ Klux bosses is plainly indicated by the following extract from the Fort Smith Herald (Democratic), published in the Gazette, February I9, I869:

"Now, Mr. Editor, we Democrats have been badly sold, and that too by the laymen of our own party, and by the Gazette, that assumed the right to dictate to us in all things pertaining to politics.

"In the first place our 'central committee' issued a mandate through its organ, the Gazette, forbidding us to vote for the constitution, and the leaders of our party took up the note and told us of the degradation that would attach to every one who would take an oath to support the abominable instrument."

The martial law policy, after its revocation, soon developed unprecedentedly prosperous conditions, a most 
striking contrast to those prophesied by the Gazette and the Ku Klux Democracy throughout the State.

Every lawyer knows that in the trial of a case testimony favorable to his client, reluctantly drawn from the. witnesses on the other side, is more effective to his cause than if given by his own witnesses. On that principle I shall leave out the many articles from the "Republican press" relative to the prosperous conditions following martial law, and reproduce from some thirty articles I have selected from the Democratic press of the State the following extracts, commencing with the Gazette, its star witness :

"May 22, I869. Little Rock. It has been growing like the trees we planted in our younger days, while we slept. The village has spread into a town, the town is expanding into a metropolis, and the real change, now that we see its magnitude, has taken many of us by surprise. . . Northern capitalists have already been attracted here, and have invested largely in city property. They foresee the rapid increase of Little Rock and the large volume of trade which is to flow from the completion of its vast railroad connections. They are taking time by the forelock and investing at low prices where they have a greater chance of making a surer profit, at less risk, than they have anywhere else."

"July 3 I, I 869 . The wages paid to negro laborers in the cotton fields of Arkansas far exceed the wages ever before paid to labor anywhere, except in California during the few years after the first discovery of gold. Labor to-day in the cotton fields of this State is more remunerative, realizes more to the laborers at the end of the year, than any prices now paid in California, or elsewhere. We are glad to be able to make the announcement. It is evidence of a prosperity introduced by the culture of a staple which must be used by the world, whatever the cost of its culture. While its cul- 
ture pays high wages to the laborer, it is seen to be remunerative also to the employer. The inevitable result is a general prosperity hardly to be found elsewhere among industrial classes."

"September 24, I 869. Our City-Her Prospects. Nor indeed are these the only evidences of prosperity. On every hand we witness a spirit of progression seldom equalled by any locality. The erection of new business and dwelling houses, every direction, is so rapid and extensive that we fail to keep pace with them. The increase in the number of business houses is so great that, although perambulating the streets daily, we are unable to keep properly posted as to their number and business. It is unprecedented; and we, in common with the transportation lines, were equally surprised at the unusually large shipments of goods to this point. With all the facilities that were afforded, and they have heretofore been considered ample, it was found necessary to charter several extra packets, and even with that merchants naturally and justly complain at the delay in the delivery of their freights."

"February I 5, I 870 . Around the City [Little Rock]. It would be too tedious to enumerate all the new houses that have recently gone up, or are in course of erection in and around the city. . . . An imposing edifice is the Blind Institute, which is nearly completed, and adds another lasting ornament to the city. From this point to the river via St. John's College we find new dwellings springing up as if by magic. The grading of Rector Avenue, which we believe is soon to be commenced, will be an addition to East End that will add much to the appearance of that portion of the city. On the corner of Orange Street and Rector Avenue we observe that Dr. J. M. Lewis, Commissioner of Immigration, is erecting a fine dwelling. As we near the river the beautiful edifice, Kramer School House, meets our view and completes our rambles.

"We have not mentioned the many dwellings and busi- 
ness houses that are going up in the city. They are equally numerous. The new addition to Sherman Street schoolhouse has made that a handsome and commodious building, in keeping with the wants and necessities of a growing population. The evidences of improvement this year are even greater than they were last. 'Onward' is the watchword. We have cause to congratulate ourselves upon the bright prospects we have before us."

"July I 2, I 870 . Our City-Progress-Railroads. For nearly ten years our city [Little Rock] has been harassed by constant strife. When we remember all these things her progress is most wonderful. Her population has increased to about five times its proportions in ' 60 , her industries, manufactures, banking facilities, and commerce have kept pace with her population. She can boast of her steam saw and planing mills, employing over 300 hands-her foundries, brick machines, and scores of business houses."

"December I 5, I870. Improvements. So rapidly does our city [Little Rock] expand and fill up with new houses and population that it is almost impossible to keep pace with the improvements that are constantly in progress. There are no idle mechanics in the city who desire work, and their pay is better than in any other Southern city. This of itself should be a good lesson to young men who lounge around the street corners too indolent or too proud to learn a trade. A good mechanic, sober, industrious, and reliable, can always find work, particularly in a progressive town like this."

"August 5, I 87 I. Improvements. The Watchword is Still Onward. We are undoubtedly safe in the assertion that no city in the South presents the same degree of activity, or gives the same evidence of thrift and progress as this [Little Rock]. Business houses are no sooner commenced than they are engaged, and no sooner finished than they are occupied. New houses are constantly opening,- - new businesses started,- - new peanut stands opened, and bootblacks on the increase. Our busi- 
ness has almost doubled the past year. Immigrants continue to come and fill up our town; in fact, there is such a bustle and hurry and going to and fro as was never witnessed before during the summer months. Business has been good all the year,- - at least, good in comparison to other cities. Manufactories are on the increaseindeed everything is upward and onward."

"March 4, 1869. [Extract from Clarksville Democrat.] The Clarksville Democrat says that in the Clarksville land district there have been, up to February 26,500 homestead locations, and that by the end of the current quarter the number will exceed $\mathrm{r}, 000$.

" "We are now entering upon a career of prosperity that is destined to bring an immense immigration to this and adjacent counties. We notice that since last fall circuit court there has not been a single suit instituted in either the common low or chancery courts of Johnson County, to the term which meets third Monday of March. Lawyers talk of going to farming. The cotton crop of I 868 for this county was about 2,250 bales; besides there was the greatest abundance of corn, wheat, and bacon for all necessary purposes. At the present time there is in the hands of the people of the county about $\$ 100,000$, after having paid up last year's credits and bought supplies sufficient to make the next crop. Our merchants are all in good credit, prosperous and making money fast, but are apparently ignorant of the fact. Our farmers are hard at work preparing to make the coming crop, which it is estimated will exceed 3,500 bales of cotton, together with breadstuffs, bacon, etc. Last, but not least, there has not been a single crime committed in our county since last circuit court. Our people seem cheerful, and if let alone, are willing to bear the burdens of their taskmasters, - pay the heavy taxes, protect themselves, keep the peace, and build up a prosperous community.'

"May 27, 1869. [Extract from Clarksville Democrat.] The Clarksville Democrat notes that several sub- 
stantial buildings are in course of construction in that pretty and prosperous little city."

"October 6, I869. [Extract from Helena Monitor (Democratic).]. One of the most encouraging signs of the times is the increasing demand for lands. From our real estate agents we learn that inquiries are daily made on this subject, and that quite a number of transactions have taken place at prices which indicate a very active feeling and confidence in the future of our county. The demand is local as well as from abroad. The colored people are beginning to realize the beneficial results of their diligent labor, and many of them are seeking. to invest their surplus moneys, providing homes for themselves and their families."

"November i 8, r869. [Extract from Eldorado Southern (Democratic).] The Eldorado Southern advocates the organization of an agricultural society in Union County. There has been a marked change in the appearance and business of Eldorado within the last twelve months. This time last year we had but two drygoods stores in operation, now we have four. One year ago there was little sign of improvement, and now we shall see signs of improvement all around. There have been two new business houses erected this year, and old ones are being repaired and remodeled. There is constant demand for lumber, and the sound of the hammer can be heard from sunrise to sunset, day after day. These are signs of returning prosperity."

"December 9, I869. [Extract from Hamburg Times (Democratic).] The good order generally prevailing in Hamburg is becoming the pride of the citizens and the admiration of strangers. Public opinion is overwhelmingly in opposition to all disorder, and all that is necessary to execute the law to the letter and to make the town pleasant and agreeable is a continuation of just such an officer as we now have.

"The labor and industry of no people on the face of the earth have been more richly rewarded than that 
of the people of our county during the present year. Crops of all kinds may not have been as abundant and as large a yield as before known, but they have been remunerative and the supply is sufficient for all practical purposes. Surely, then, there is much to encourage every good citizen to increased diligence in the cultivation of social relations, strict obedience to law, the enforcement of good order, and that untiring industry and rigid economy that tends so much to make a nation of people individually and collectively good, wise, great, and independent."

Having produced this evidence from the Democratic press, I shall now conclude with evidences from other sources. I quote as follows from the report to the Secretary of War from Gen. J. A. Mower, commanding the district of Arkansas, December 14, I869: ${ }^{3}$

"Owing to the action of the Legislature in providing for an organization of militia, and the proclamation of the Governor declaring martial law in November, I868, which was followed by putting the militia in the field, the civil authorities of the State have made themselves respected; and the laws can be executed without much difficulty. This end was reached mainly through the decided action of His Excellency, Governor Clayton, assisted by the United States troops when called upon. Comparative quiet has prevailed and the troops have had nothing save routine garrison duties to perform."

United States District Judge, Henry C. Caldwell, who was present throughout all the disturbed conditions, was at first opposed to my martial law policy. His final conclusions will be clearly shown from the following correspondence. I quote from my letter to him, under date of January 8 , I9I 3 : 
"You will doubtless remember that after the conclusion of the contest you wrote me a letter frankly stating that you had at first been opposed to my martiallaw policy, but that its beneficent results in the establishment of peace and order had caused you to change your views, upon which results you heartily congratulated me. I do not undertake to give the language of your letter but this was about its purport. Will you endeavor to recall what you then wrote me and either confirm my recollection as above stated, or state in your own language now the opinions you then expressed, authorizing me to use it in the publication, if I so desire."

From his reply to this letter, under date of February 20, I9I3, I quote as follows:

"Your recollection is in exact accordance with the facts. I did write you a letter confirming my error and congratulating you and the people of the State upon the happy outcome of the policy you pursued. I will add that about the time I wrote you the letter referred to I had a conversation with Mr. Justice Miller of the Supreme Court of the United States, in which he commended your course in the highest terms, declaring you were the only Governor in the reconstruction states who had the courage and sagacity to pursue the right policy and enforce the laws and maintain the peace of the State against all lawless and illegal combinations by the vigorous exercise of the lawful powers of the State, instead of appealing to the President to send Federal troops into the State for that purpose (as other Southern Governors had done), which would have been a confession of weakness that would have encouraged, strengthened, and protracted the lawlessness, instead of putting an end to it."

Mr. Justice Miller of the Supreme Court, to whom Judge Caldwell referred, then had circuit court powers 
which included Arkansas. He was in Arkansas during nearly all the time martial law was being executed, and was well informed as to the conditions preceding its declaration as well as to the conditions and results of its operations.

From the official report of General Porter to General Grant, under date of December 26, I868, I extract the following comments as to the opposition to martial law by General Smith of the United States Army, commanding the troops there, and his change of views experienced later : ${ }^{4}$

"The entire conservative wing of the Republican party was opposed to the declaration of martial law, including General Smith, United States Army, commanding the troops .... It has, however, accomplished much more than the most sanguine expected, and General Smith acknowledges that the Governor's policy was better than his, and that the results would fully justify the action of the former. The Governor is now disposed to relieve each county from martial law as soon as it can be done. The Governor is certainly a man of intelligence and nerve and has labored under difficulties that would have deterred a less able officer."

There now also became apparent marked evidences of security to life.

I suppose there was not then in the State a more unpopular man than I was among the Ku Klux masses; yet, having given ample notice of my intention to visit the localities that had been under martial law in the territory south of the Arkansas River, I filled these appointments, commencing at Lewisville in the southwest corner of the State, and spoke in the various counties where martial law had been in existence, ending at Monticello; traversing all together a distance of 406 miles, with 
no one to accompany me except Gen. Keyes Danforth, who drove the buggy in which we rode.

In each of the places where I spoke I emphasized this fact as an argument and illustration of my confidence in the peaceful disposition of the people now that they had been freed from $\mathrm{Ku}$ Klux terrorism. I assured them that martial law had not been proclaimed to punish individual $\mathrm{Ku}$ Klux, but only those who were making direct war against the State Government and those who had been charged with the commission of capital crimes, and that my object was to relieve the people from the terrorism of that organization,-a terrorism that was produced by desperadoes acting under its arbitrary dictates. Upon such assurances I indulged the hope that all good citizens would exert themselves to the utmost to sustain the local authorities.

At each of these county seats I was assured by all classes of citizens of their determination to render to the county officials such aid and support. I believed then and I believe now that these assurances were generally given to me in good faith and were afterward so carried out.

At Monticello occurred an incident that touched me very much, although it originated from a very humble source. It had rained the day previous to the speaking, and in going across the street to the speaker's stand I left a very clear imprint of one of my feet in the plastic mud. An old negro went into his cabin and procured a spade with which he marked a slab and then shovelled up a sufficient amount of the mud to leave my footprint undisturbed. This he afterward allowed to dry in the sun and kept in his cabin as a memento of my visit to Monticello. The negroes felt that by my efficient measures I had given them a second freedom and secured them from intolerable outrages. 
At all these appointments the people turned out almost en masse, and treated me with the utmost respect.

\section{FOOTNOTES FOR CHAPTER VIII}

${ }^{1}$ Published in Arkansas Gazette, November 26, 1868.

${ }^{2}$ Published in Arkansas Gazette, January 8, 1869.

${ }^{3}$ War Department Doc. No. 7-I467, S. A. G. O., I 869.

${ }^{4}$ Memphis Evening Post, January 8, 1869. 


\section{CHAPTER IX}

\section{IMMIGRATION}

Closely akin to the evidences of peace and prosperity which I have just described is the great influx of immigration which followed, and which was too pronounced and indicative of the prosperous conditions not to be brought to the especial attention of the reader.

Both parties in Arkansas favored immigration, but were widely divergent as to the character of the immigrants sought, and the rights and immunities of the newcomer as compared with the old citizen. To elucidate the Democratic view, I will present a few extracts from the Gazette, as follows:

"November I, I $866 . .$. . One of the most terrible results of the war is the destruction of the labor system of the South .... O Our people are particularly attached to the plantation system, which has prevailed heretofore among us. The introduction of a foreign element as laborers will tend to destroy this ancient system ....."

"January I9, I $867 \ldots$. We want them [immigrants] to bring with them labor and capital, and not a stock of political morality to force down the throats of supposed barbarians. We desire the greatest amount of industrious energy, with the least possible amount of politics ...."

"January 22, I 867 . It is to be desired that the ownership of the soil of our State remain for the greater part in our ancient population and their descendants, as 
the proprietors of the soil give the tone to the character of the people of a community."

"October 4, I $867 \ldots$. . Those who have lately come to our State and have adopted it as their future homes, if they are the right material, will not be forward to secure public offices...."

"January I9, I $870,-C h i n e s e$ Immigration Movement,-The Republican, quoting the Gazette:

". . . We certainly do not feel disposed to combat the influences at work to encourage such a movement. But if the negroes of the South-who have, homeless, penniless, and naked, brought her out since the surrender to her present condition of prosperity-were their own friends, the friends of the country, and our friends, instead of lending themselves body and soul to those whose only object is to oppress and devour them and us, we should most strenuously oppose the introduction of Chinese laborers into this once pure and proud republic."

Undoubtedly the underlying motive for this effort to bring in Chinese laborers was to punish the negro for having abandoned the control of his old master, and to regulate the conditions of his employment and the scale of wages to be paid him.

On February II, I 890 , upon the invitation of the "Mystic Valley Club" of Boston, Mass., I delivered a speech on the "Southern Question," from which I quote as follows:

"In Arkansas there is a county named Woodruff, where lately an immigration society was organized, the first act of which was the making of a 'black list' of Republicans, white and colored, who were to be boycotted and driven out, which resulted in a large emigration, some perhaps returning to their former northern 
homes, thus swelling the northern-born citizens who have left the south, as referred to by Mr. Grady [in his Boston speech upon the same subject]. To fill the vacancies in the fields and elsewhere, caused by this exodus, this immigration society employed an agent, whose prospectus I hold in my hand, in which, after recounting the natural and other advantages of Woodruff County, he uses the following language:

"And be it to the honor and credit of this particular neighborhood that its society is of the best and most intelligent in the State.'

"Further on he said:

" 'Don't arrange to carry anything but clothing, bedding, and dishes. The articles named want to be packed in boxes not to weigh more than 250 pounds, so that it can be checked as baggage. The county is under Democratic rule, and we want only straight Democratic men, who wish to become citizens and better their condition.'

"This circular is signed by R. A. Williams, General Agent, Atlanta, Georgia. It seems that the immigrants the best society desire are men whose earthly effects can be checked as baggage, and being Democrats, they need have no fear of being called carpet-baggers."

In my message to the Legislature, dated July 4, I 868 , I expressed my views upon the question of immigration in the following language: ${ }^{1}$

"There is probably no question that will affect the future destinies of Arkansas so much as that of immigration.

"Providence has richly endowed our State with those elements of wealth that are necessary to constitute an independent and self-supporting community. Yet, in the midst of this great age of progress and improvement, our primeval forests, as of yore, rear their arms to Heaven and seem to defy the hand of man. Millions of broad acres, teeming with fatness, and fertile beyond 
description, patiently await the 'open sesame' that shall unlock and develop their varied stores. Limitless wealth buried under broad hills, concealed in secluded valleys, and hidden in mountain caves, awaits the glad advent of the pick and bar.

"Reflecting upon our great agricultural staple, we involuntarily pause to listen for the hum of machinery and the clank of the loom.

"After a patient waiting of half a century, the light of a higher civilization has burst upon Arkansas.

"The vast tide of immigration that, from across the waters, has been moving westward for so many years, peopling territories, building cities, and creating States with magical rapidity, only awaits our action to pour itself within the limits of our State.

"We should invite all classes to come here and we should greet every one with a cordial welcome. Capital should be protected, industry fostered, and over each individual should be extended the strong and protecting arm of the law,-guaranteeing upon the soil of Arkansas equal rights to all men.

"I confidently expect that at an early period you will establish a liberal and vigorous bureau of immigration; and I earnestly recommend that you so define the duties of the commissioner, and clothe him with such powers in relation to his intercourse with the most populous parts of this and foreign countries, as shall enable him to cope successfully with the agents of other States, and to direct the capital and labor of the North to this more genial climate; and by a thorough diffusion of facts and statistics so to determine the line of immigration from Europe to this State as will make us the recipients of those elements of wealth and prosperity, from which, by the old order of things, we were effectually debarred."

The fact that the Legislature took up and passed unanimously, on July I 8 , I 868 , a bill ${ }^{2}$ embodying my recommendations sufficiently shows that my views were 
not only a reflex of those of the Legislative Department, but of the Republican Party throughout the State.

In my message of November 24, I 868, which was afterward published in pamphlet form and given a wide circulation at home and abroad, I again expressed my views upon this subject as follows: ${ }^{3}$

"It is of vital importance to the growth and development of our State that every encouragement be given to the introduction of settlers from abroad; and this can only be accomplished by securing entire protection and perfect freedom of thought and action to all who may desire to come among us. Our past record of murders and outrages, and absence of law and order, is, it is true, bringing us a very considerable immigration from Texas, Louisiana, and other places, and it will continue to do so as long as these evils exist; but it is an influx of desperadoes and outlaws, who are seeking an asylum here on account of their crimes, to find a locality congenial to their manner of life, and adapted to the furtherance of their designs in the future. It depends upon us whether we shall make our State the hiding-place and home of the assassin from other States, as well as from our own. The settlement of the question depends upon the restoration, all over the State, of law and order.

"Good citizens will not come here to seek homes for themselves and their families, where they are subject to all these perils, unless they surrender to others their manhood and freedom. They demand the right to think, speak, and vote in accordance with the dictates of their own judgment and wishes, 'none daring to molest them, or make them afraid.'

"Possessing a soil unsurpassed for productiveness, a delightful climate, and an immense amount of cheap land, together with very valuable mineral resources, we offer to the overcrowded cities and communities elsewhere sufficient inducement to bring among us an immense tide of population. 
"It needs only that the suicidal policy of the past be entirely laid aside; that all who desire to come be guaranteed entire security and protection; that the spirit of lawlessness be overcome, and a spirit of acquiescence and obedience to the laws take its place, to bring into our State an amount of capital and a tide of population that will enable us to develop our resources and make rapid strides in the great march of progress and advancement.

"When we are true to ourselves and to one another, and to the great destiny that Heaven has spread out before us, then indeed will our prosperity be great and our advances rapid. Then will the abundant resources of our State be in full process of development. Then will all conditions of society, like sound members of a healthy system, be united in one strong organic body. Towns and villages will spring up, capital will come among us, property will increase in value, our agricultural productions will be multiplied, and we ourselves, throwing aside every weight, be successful competitors in the great race of civilization and improvement.

"In my convictions of right and duty, I trust I am, with you, firmly grounded in that truly republican faith that recognizes the claims of loyalty, liberty, and humanity. The nationality that is symbolized by one flag, one people, and one Government; the liberty that sinks alike all questions of race and creed; the humanity that protects the rights of the humblest in the land forms the basis of a creed that no temporary change of public opinion can ever shake. Planted upon that basis, our State will be truly reconstructed, and its upward and onward career will be assured alike by the wisdom of man and the favor of God."

The issue being squarely joined, both parties went vigorously to work to establish their particular views. The opponents of the State Government plan confined their efforts principally to the bringing into the State of Chinese immigrants, in fact Chinese laborers. 
A Chinese Immigration Convention assembled at Memphis, Tenn., on July I3, I 869, with a large representation, principally planters from Tennessee and Arkansas, at which Convention ways and means were provided for the success of their purposes. Conventions were also held in Arkansas, and the efforts of the planters were especially exerted for the substitution of Chinese immigrants, as they were called, for negro labor.

I give the following extract as to the Memphis Convention: ${ }^{4}$

"July I3, I 869. Memphis, July I2. Hotels are rapidly filling up with delegates to the Chinese Labor Convention to-morrow. Koopmanshop, the importer, telegraphs that he will be here to-morrow. Planters from various parts of the southwest are here in strong force."

These efforts resulted in introducing into the State, especially in the cotton planting region, a considerable number of Chinese, brought, in most cases, in groups by agents. I insert copies of all the documentary evidence I have that bears upon this aspect of the case, from the Gazette, as follows:

"June 8, I870. The Pine Bluff Press [Democratic] of the $2 \mathrm{~d}$ instant contains an interesting report from Capt. George Gift, agent of the Arkansas Valley Immigration Company, who has recently returned from the Celestial Empire with a cargo of Chinamen for that company .... The Chinese will soon be here, and Captain Gift says it remains for the planters to dissipate the ideas of ill treatment that prevail in China,-prove to them that they can earn wages, receive reasonable treatment, -and they will flock to us by the thousands. It required several years to start them toward California. Twentyfive thousand go there now annually at their own cost." 
"August I3, I870. A Chinaman has the same right to be born in the world as any other child of Adam. Having a right to live, he has a right to earn his livelihood wherever he can best find work and wages. Knowing that of all countries on earth America offers the greatest advantages to working men, he has a right to come hither and take his chances with the rest. Being here, he has the right to be treated with the same justice and generosity as we show to other men. And that is the sum and substance of the Chinese question."

The efforts to utilize Chinese labor proved a disastrous failure. Planters soon learned that after all the negroes, as laborers in the cotton fields, were better in all respects than the men of any other race, and in a little while the Chinamen sagaciously learned the purposes for which they were introduced. I do not know of a single plantation that is now worked in whole or in part by Chinese labor.

On the other hand, the following extracts from the Gazette, copied from various newspapers in the State, conclusively show the success of the plan of the Administration:

From the Gazette, August 3, r 869: "Benton County received last week an accession to its population of some three or four hundred German immigrants. This thrifty class of people is beginning to rush into the State at all points, hundreds having already settled, and more constantly coming into the counties east of us and bordering on the Missouri line."

From the Gazette, October 27, I 869: "There are a great many immigrants passing through our town bound for this State and Texas. As a class they are very intelligent, hardy-looking people, have good teams, and will contribute to the development of the country in which they may settle. We are glad to learn that some 
are stopping in Washington County, the garden spot of Arkansas."

From the Gazette, quoting from the Pine Bluff $R e$ publican, November I 8, I 869 : "Immigrants by hundreds are daily passing through Pine Bluff. From present appearances Arkansas will receive no less than an addition of 10,000 souls to her population this winter and the coming spring. The people in the old states are beginning to find out the vast advantages offered by our State, and are flocking to us by the hundred."

From the DeValls Bluff Journal, December I, I $869:^{5}$ "More than one hundred families of immigrants have settled in this County (Prairie) within the last month. Every house in town is crowded, and still they come. We have room for more."

From the Gazette, December I9, 1869: "A friend writing from Clarksville, under date of the I $3^{\text {th }}$ instant, says: 'You would be astonished to see the immense immigration pouring into the Arkansas Valley, and they all seem to be of the right sort,- the hardy sons of toil, who come to work and make a living and build up the fortunes of the State. The speech of Governor Clayton [my message to the legislature of November 24, I 868] has done more to give encouragement to immigration, and to assure protection to settlers and encourage their coming among us, than all the immigration agents he could appoint. Before that speech people were not disposed to risk their all, life, liberty, and property, in a state governed by a mass of ignorant, unprincipled, and savage militia.'

From the Gazette, December 2 I, I 869,-extract from the Republican: "Almost every boat that comes into the Arkansas River is crowded with people seeking homes in this State. This is really cheering and propitious for the future prosperity of Arkansas, and it is not very difficult to see what the future has in store for her."

From the Gazette, December 25, 1869: "A large 
immigration is taking place to Montgomery, and as a consequence, Mount Ida, Harold, and Centreville are all receiving increased prosperity."

From the Gazette, December 25, i 869 : "A correspondent from Danville, under date of December 20: 'Immigration is pouring into our county [Yell] rapidly. Georgia seems all at once to have emptied all her surplus population into this part of Arkansas, and the result is we are about overrun with immigrants. Every hut and cabin in the whole county is full to overflowing. There are numbers of families who cannot find homes, and the cry is 'still they come.' "

From the Gazette, December 28, I 869-extract from the Times: "Arrangements are being completed for the consummation of the land purchase at Spadra. It is promised that over 4 oo German families will settle there in the spring."

From the Gazette, December 28, I 869: "The increase of population in Arkansas is becoming immense. The steamers, seven, making almost daily trips to Memphis, belonging to the Memphis and Arkansas River Packet Company, are thronged during every trip, besides the influx by the other capacious and numerous boats plying in the White and Arkansas Rivers. The Caldwell's receipts last trip from Memphis from passenger fare alone were three thousand dollars. While we most cheerfully welcome immigrants to our State from any of the States in the Union, 'without regard to color, race, or previous condition,' it is pleasant to know that the majority of these now coming to make homes in Arkansas are southerners, frugal and industrious citizens from the Carolinas, Tennessee, Georgia, and Alabama. Much is conceded to the enterprise of the people of states farther north; but for true economy and the substantial developments of the material interests of any agricultural country, there is no better citizen in the world. We do not say that western farmers from farther north are not as good as they are, but we feel safe in saying they are 
no better. Our prospects are brightening, materially, socially and politically."

The immigrants referred to in this article, although from the Southern States, came principally from the mountain regions and were mostly farmers seeking cheap lands as a wise precaution for the rapid increase of their families. Nearly all were Republicans, and not of the old slaveholding régime.

From the Gazette, January 4, 1870 : "It is gratifying to witness the great influx of strangers to this county [Independence], many of whom are purchasing land and locating. During the past two months more strangers have located here than at any time embracing the same period in the history of the county."

From the Gazette, January I 2, I 870 : "The Clarion [independent paper], in an article upon the immense immigration which has spread over our State during the past autumn, and which still continues, concludes its article as follows:

" 'One great thing with persons seeking new homes is as to the quiet of the State and the security of person and property. In all respects we think Arkansas will compare with any other State in the Union. We still have a few wild, reckless men among us, but they are rapidly dying off. Their very recklessness and dissipation are killing them, and we think we risk but very little when we say that Arkansas is as free of that class of men as any State in the United States." "

From the Gazette, January I 9, I870,-extract from the Augusta Sentinel [Democratic]: "Dr. H. K. Steven, who for several months past has been in Tennessee, engaged in promoting immigration and assisting in bringing settlers to our county [Woodruff], returned Monday last bringing about I5O immigrants with him, who are finding homes upon the rich unoccupied lands of our county. The doctor has been engaged in a good work, 
and we are glad to note this evidence of his success. We are credibly informed that not less than three hundred persons have settled in our county during the present fall and winter, and more are coming. Lands are steadily increasing, and those who would avail themselves of the present low prices must purchase soon, as the present year will witness an influx of settlers unprecedented in the former history of our State."

From the Gazette, January 27, 1870: "As will have been observed from the many extracts we have published from our State papers, from time to time, an immense immigration has been settling into our State, which still continues."

From the Gazette, May 14, 1870: "The Coming Splendor of Our Prosperity-We have often adverted to the rapidity with which the population and wealth of this State were augmented. In fact its growth in every element of greatness is infinitely more rapid than is apparent to any casual observer of the course of events. Through the past fall and winter and spring, vast numbers of immigrants from the older States have sought homes along our rivers, and many more are attracted hither by the mere fact that Arkansas is deemed the most prosperous of southern States."

Believing that I can safely rely upon the intelligence of my reader to differentiate between the two policies I have outlined, I will content myself with some general remarks. The anti-reconstructionists had one principal object in view - the re-possession of the State Government and all its privileges and emoluments. Therefore, they looked with disfavor on any plan that would bring to the State an influx of Northern and foreign immigration. The condition throughout the South being similar to their own, they could not expect any considerable immigration from that quarter; hence, what they called their immigration policy was in reality but a labor ques- 
tion, whereby, regardless of the consequences, they advocated a policy that would not only add to the perplexities of the race question, but also to the incongruity of the citizenship of the State generally, and would continue the old policy of neglecting all other interests save that of agriculture.

On the other hand, the immigration policy of the State Government was that which filled up and rapidly brought to conditions of statehood the unoccupied regions of our mountain States, where every immigrant was welcomed on terms of equality.

\section{FOOTNOTES FOR CHAPTER IX}

${ }^{1}$ Arkansas House Journal, I868, pp. 293-294.

${ }^{2}$ Arkansas Laws, 1868, pp. 124-126.

${ }^{3}$ Arkansas House Journal, I 868-69, pp. 26-28.

${ }^{4}$ Published in Daily Gazette, July 13, 1869.

${ }^{5}$ Republished in Daily Gazette, December 7, 1869. 


\section{CHAPTER $\mathrm{X}$}

\section{EDUCATION}

Having described the closing of the Ku Klux Dens, a description of how the schoolhouse doors were opened becomes now a more pleasing subject. The opening of these doors was the task that lay nearer my heart than any other of my official duties.

The United States Census of I 860 shows that the entire number of slaveholders in the State at that time was $\mathrm{I}, 48 \mathrm{r}$, or about $3 \mathrm{I} / 2$ per cent of the white population. As incredible as it may appear, this small percentage of citizens dominated the politics of the State throughout its whole history. This evidently grew out of the following facts:

The slaveholders were the possessors of the wealth, educational facilities, and the governmental machinery. A community of interests in their slaveholding assets created a bond of union that made organization unnecessary. This policy was readily supported by the classes dependent upon the slaveholders, such as overseers, doctors, lawyers, merchants, and others.

On the other hand, the non-slaveholders, constituting the great mass of the white population of the State, were without educational facilities. Scattered at considerable intervals and being without money, organization, or leadership, they were confronted by irresistibly repressive influences and they chose rather to "bow their heads to the yoke" than to engage in a strife that would have been absolutely futile. 
To prevent any bond of sympathy between the slaves and the illiterate non-slaveholding classes, the former were taught to look down upon the latter with contempt and to characterize them as "poor white trash." This in turn caused this class of whites to become negro haters.

Upon the admission of the State into the Union, and at various other times, the General Government had been most liberal in its donations in aid of free schools. The following description of these donations is based upon the report of Woodville E. Thompson, State Superintendent of Schools, dated October, I890:

By act of Congress, March 2, I827, seventy-two sections of land were donated for the establishment of a Seminary of Learning. The provisions of the act of Congress, June 23 , I 836 , resulted in confirming to the General Assembly of the State of Arkansas the title to the I 6th section of every township, and the seventy-two sections of land known as the "Seminary Land" above referred to.

July 29, I 846 , Congress assented to the adding to the I6th section lands the Seminary Lands for the purpose of establishing a system of free schools. The revenues derived from such donations were squandered by ignorant county superintendents and other local officials.

To show the utter failure of the old political régime to establish free schools in the State after its admission to the Union, I quote as follows from the message of Gov. Henry M. Rector to the General Assembly, November I 5 , I $860::^{1}$

".... The common school system also seems to be radically defective. In the last report made by the Secrectary of State, as State Commissioner of common schools, it may be seen that there are only twenty-five common schools organized and kept up in the whole 
State, from the common school fund. This is a sad commentary upon the present system.

"Under existing laws, it is made the duty of the common school commissioners of the different counties (fifty-five in number) to make out and transmit to the Secretary of State, annually, a report showing the condition of the common schools and school funds in their counties, respectively. It is lamentably true, however, that out of this number only three of them have reported at all for the present year; two of which reports are totally devoid of the required information.

"The general law provides for three trustees and one treasurer in each congressional township. Each county, containing thirty-five townships, would have, including the commission, one hundred and forty-one officers. Multiply this by the number of counties and you have in the State seven thousand seven hundred and fiftyfive men to perform what ten would do better."

It was these last remarks of Governor Rector's that suggested to me the Circuit Superintendent system, which placed the work throughout the State in the hands of competent officers who were qualified to put it in practical operation, instruct minor officers in their duty, and inculcate in the minds of parents and guardians the great advantages that would accrue to their children by placing within their reach the means of acquiring a good free school education.

The Census Report of i 860 , under the head of what it termed "Public Schools," is misleading. While there may have been seven hundred and thirty-two schools, they were not free schools but were common schools, which under the law then existing were maintained by subscription, aided by a distribution, or misappropriation, of the free school funds.

The hostility of the slaveholders, and the indifference 
of the other classes, to any system of free schools, Superintendent Thompson, heretofore referred to, described in the following language: ${ }^{2}$

". . . The free schools were looked upon by our citizens generally as pauper establishments, not to be patronized by the better class; and the prejudice permeated all grades of society."

From I 860 until the close of the Civil War schools of all descriptions ceased to exist in the Confederate States, and among the many evils brought on by that war perhaps not the least baneful was the increased ignorance and its attendant pernicious influences. After the Democrats got control of the "Murphy Government" in I 866, an effort was made to reëstablish the old system of common schools, in which no provision was made for the education of the lately enfranchised negro.

Having resolved to recommend to the Legislature the adoption of an entirely new system of free schools, open to all, and upon a complete reformation of the old system so graphically described by Governor Rector, after much deliberation I brought the matter to the attention of the Legislature in my message of July 4, I868, as set forth in the following extract: ${ }^{3}$

"Your attention is respectfully invited to a question that is perhaps more important than any you have been called upon to consider. It is that of universal education.

"To the ears of the oppressors this is a startling and dangerous subject, for wherever the ennobling influence of education is felt the shackles fall from the limbs of the oppressed; the slave becomes a freeman. To the lover of freedom it is the very 'philosopher's stone' that changes the base metal of the ignorant and slavish mind to the pure ore upon which the light of liberty is caught up and reflected upon other minds until the whole becomes illumined. To us it is the keystone of the grand arch 
upon which rests the fair structure of our free government. No State founded upon the principles on which our government is based can prosper where ignorance prevails. The people cannot rule successfully unless they are educated and informed.

"Free schools and free labor are necessary adjuncts; they go hand in hand. The one produces from the garden of the mind its choicest fruits, the other causes 'the wilderness to blossom as the rose.'

"The wicked and shameful manner in which the servants of the people have neglected their educational interests and appropriated to their own selfish uses and the unhallowed purposes of treason the magnificent endowments of a generous government subjects them to the merited condemnation of all true patriots. In regard to the advancement of the common school interests, the question heretofore seems to have been, not how to do it, but how not to do it.

"A comparison of the condition of common schools in this State, as shown by Governor Rector's message delivered to the General Assembly, November I5, I 860,heretofore quoted, - with that of the State of Michigan, which became a member of the Federal Union at the same time as Arkansas and under circumstances less favorable, is calculated to create a sickening sensation in the breast of one having the interests of education at heart.

"In r 855 Michigan maintained 3,255 common schools and employed 5,078 teachers. In I 860, as shown by the message above referred to, but twenty-five common schools were organized and kept up in this State from the common school fund. I am unable to give you correct information of the number of common schools now in operation, but for practical purposes it would be safe to proceed as if there were none.

"From reliable statistics obtained from the list of registered voters, made last fall, it is shown that thirty per cent. of the white and fifty per cent. of the entire 
voting population were unable to write their own names. Nothing but a due sense of my constitutional obligations, and an earnest desire to promote the educational interests of the State, induces me to make this shameful disclosure.

"Fortunately, after thirty-two years of ignorance and misrule, a way is at last opened through which the light of intelligence can enter and shed its beneficent rays over the whole State. The framers of our present Constitution have placed themselves in enviable comparison with past legislators, and merited the approbation and gratitude of posterity by that one act of far-seeing statesmanship, which secures to future generations the inestimable boon of education and gives life and perpetuity to the State by providing the means whereby its future supporters and defenders may be prepared for the proper exercise of the duties of American citizenship.

"You are expected to take up this work, which has been so well begun, and at an early day devise and establish a wise system of common [free] schools; one that will not be out of proportion with our limited means, but will be so adjusted as to grow with our growth and strengthen with our strength. After a system is established, the work of execution should be put into the hands of competent men, depending more upon efficiency than numbers. The work that under the present system is entrusted to nearly sixty-five officers, could, in my opinion, be more efficiently performed by ten. I, therefore, respectfully suggest the propriety of abolishing the office of county school commissioners, and creating in lieu thereof district superintendents for each judicial district that is now, or that may hereafter be, established.

"These district superintendents should be charged with the work of organizing school districts, and establishing schools; they should have immediate supervision over the school directors of the various school districts, and see that said directors perform their duties properly and according to law; they should examine and license 
teachers, and organize teachers' institutes; they should provide rules and regulations for the government of schools, and visit the schools frequently for the purpose of ascertaining the efficiency of the teachers; they should examine the titles of all school lands that have heretofore been disposed of, and report to the proper officers such, if any, as are illegally held and their condition.

"In short they should have full supervision of all matters pertaining to the school interests in their respective districts. In addition to these duties, the district superintendents, with the State superintendent, as presiding officer, should constitute a board of education, which should meet at the Capital yearly, and have conferred upon it such legislative powers as may enable said board to make such amendments in the school system as the application of theory to practice, or the exigencies of the educational interests, may demand.

"The present condition of our school interests is unprecedented. A large portion of the community is known to be antagonistic to the principles of universal education. The prejudices that exist against a certain class of the people will tend to embarrass the situation. Obstacles will doubtless be thrown in the way where active support should be given.

"The establishment of the school systems of the older States has been the work of years. We cannot expect to apply successfully the elaborate plans that they have slowly perfected and adjusted to suit their enlarged views and peculiar localities and conditions at once to our State. Before we can arrive at such a degree of perfection the people must be educated as well as the rising generation.

"Any system that we may agree upon will, doubtless, require frequent adjustments before it will be found to work well in practice. It is for this reason that I recommend the establishment of a board of education."

My recommendations were embodied in an act of the Legislature passed unanimously by the Senate on July 
I6, I 868 , and by the House, July I 8, I 868 , by a vote of 37 to 19. The negative vote in the House did not indicate opposition to the bill as a whole, but only to that part of it that provided for separate schools for the races. To have provided for mixed schools, under the existing conditions, would have been destructive of all we were laboring to accomplish. In making my recommendations to the Legislature I had to provide for conditions as they were and get the best results I could out of the new system, which provided for absolute segregation of the races.

From my message to the Legislature, January 2, $\mathrm{r} 87 \mathrm{I}$, relating to the progress of the educational work, I quote as follows: ${ }^{4}$

“. ... The report of Hon. Thomas Smith, Superintendent of Public Instruction, however, furnishes statistics showing so much more accomplished than many of you are aware of, and, moreover, contains so much matter of general interest, that I subjoin some statements from it, referring you for full particulars to his able report: ${ }^{5}$

"Number of children of school age, I $869 \ldots$ I 76,9 Io Number of children of school age, $1870 \ldots$ I 80,274

\section{Increase 3,364}

"Number of children attending school in I 869. . 67,4 I 2 Number of children attending school in $1870 \ldots$ 107,908

Increase $\overline{40,496}$

"Number of teachers employed in $1869 \ldots \ldots \quad$ I,335

Number of teachers employed in $1870 \ldots \ldots \quad 2,302$

Increase 
“Number of Teachers' Institutes held in I 869 . .

"Amount paid to teachers in I869......\$188,397 Amount paid to teachers in $1870 \ldots \ldots \ldots \$ 405,748$

Increase $\$ 2 \mathrm{I} 7,35 \mathrm{I}$

"Number of schoolhouses built prior to i 869 . . Number of schoolhouses built I 869 and I 870

$$
\text { Total } \longdiv { \mathrm { I } , 2 8 9 }
$$

"Number of persons subject to per capita

$$
\text { tax, I } 868 \ldots \ldots \ldots \ldots \ldots \ldots \ldots \text { 7 } 1,89 \text { I }
$$

Number of persons subject to per capita

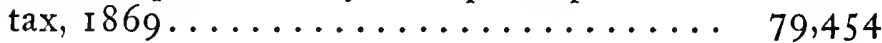

Increase 7,563

"Amount of tax collected from this source

in $1868 \ldots \ldots \ldots \ldots \ldots \ldots \ldots \ldots \ldots \ldots \ldots \ldots$ Amount of tax collected from this source

in $\mathrm{I} 869 \ldots \ldots \ldots \ldots \ldots \ldots \ldots \ldots \ldots \ldots \ldots \ldots \ldots \ldots$

Increase $\$ 9,365$

"Apportionment of school tax in I868... \$ \$190,492.86 Apportionment of school tax in $1869 \ldots \ldots$. $187,427.08$ District tax in $1868 \ldots \ldots \ldots \ldots \ldots \ldots \ldots 105,235.00$ District tax in $1869 \ldots \ldots \ldots \ldots \ldots \ldots 320,583.79$

Increase $\$ 2$ I $2,283.01$

"So encouraging a statement of the work accomplished in this direction cannot but be a source of con- 
gratulation. It is impossible to estimate too highly the importance of good and abundant public schools in any community. To educate the people is one of the highest duties.

"Every effort made for the accomplishment of this object should be encouraged. Every interest and every industrial pursuit will be aided and promoted by its operations. Every man who is educated is improved in usefulness, and is in every respect more valuable to society. That this subject is being properly agitated is evident from the rapid advance made in the past two years, and we may now confidently anticipate that in a short time the means of obtaining for their children a good free school education will be within the reach of every family in the State."

In stating the total number of schoolhouses built prior to I 869, Supt. Thomas Smith, in his foregoing report, should have enumerated the schoolhouses built out of the Common School Fund, the Peabody Educational Fund, and the Freedmen's Bureau Fund.

By the Common School Fund I mean the fund raised from all sources to support the common schools, which were not free schools. The Peabody Educational Fund and the Freedmen's Bureau Fund were, at the time of the winding up of those institutions, turned over to the Arkansas Common School Fund and became a part thereof. Doubtless all the schools established, of every description, were included in those given in the Census report of I 860 . $^{6}$

The Gazette, true to the Democratic policy, under the pretext that the salaries of the circuit superintendents were exorbitant, persistently attacked the whole school system. The facts were that it was becoming too popular with the illiterate Democracy of the State and it had to be checked. 
The salary which the Circuit Superintendents received was $\$ 3,000$ a year. At first thought that may seem excessive to some of my readers, but when it is known that all the expenses incurred in the performance of their duties-covering a territory of from five to seven counties each, with but forty-five miles of railroad in the entire State-were paid from that amount it will be evident that the execution of their duties entailed extraordinary expenses.

It is to be regretted that the School Law, providing for the Circuit Superintendent System, did not fix a specific amount for the salaries of the superintendents, and provide by separate appropriations for all expenses incurred in the administration of the law, thus removing the unjust criticism of the entire system, - a criticism that was persisted in so strenuously by its enemies.

I watched closely the official work of each superintendent, and when I found a lack of zeal and efficiency the official ax immediately fell upon the neck of the sluggard. Two examples proved sufficient, and thereafter the whole body worked effectively and harmoniously, entitling them to the highest meed of praise.

Twenty-two years after the establishment of the new system Superintendent Thompson, in his aforesaid report, used the following language $:^{7}$

"When Superintendent Smith took charge of the office in I 868 the unsettled and disturbed condition of society during an excited political canvass operated greatly against the advancement of free schools, but from the date of his administration we may also date the beginning of popular education in Arkansas-schools free to all, and every child entitled to the same rights and privileges; none excluded; separate schools provided for the white and the black; many schools organized, houses built, and efforts made to employ more efficient teachers." 
This noble recognition from an officer of opposite political views could not, in my opinion, be improved, except by fixing the date of the passage of the act as the "beginning of popular education in Arkansas."

Superintendent Smith was opposed to the system, but not on account of excessive salaries, and he was really entitled to no special credit for its success. If the law had given him the appointment and full control of the circuit superintendents, the matter would doubtless have appeared to him in a very different light.

Up to the time I vacated the Executive Chair in March, I $87 \mathrm{I}$, the work had been a complete success, büt from that time onward the annual enrollment of school children fluctuated very considerably, with a pronounced downward tendency. The wonderful success of the system, as shown by the enrollment of 107,908 pupils during the year 1870 , caused the Democratic party at once to make unrelenting war upon it, and, as a party measure, induced many of the Democratic parents and guardians, in their blindness, to withdraw the children under their control from the free schools.

Then came almost a death blow to the whole system-the enactment of the law by which the Auditor was required to issue warrants against the Treasurer for all audited accounts against the State. ${ }^{8}$ These warrants were called State Scrip, and resulted in the organization of a "scrip ring" of speculators, who bought up scrip at low prices, according to the necessities of the impecunious holders of the scrip, including circuit superintendents with moderate means and large families dependent upon them, teachers, and school district trustees. Employees whose necessities compelled them to turn their monthly payments into cash had to go to the local county ring, which offered them the alternative of buying the scrip at its own price, sometimes as low as 40 per cent on the 
dollar, or to look elsewhere. Of course if the owners of the scrip could have waited until the time came for the collectors of taxes to make their settlements with the State, when this scrip was redeemable at par value, they could then have gotten full value for their warrants.

This act caused the most efficient school employees to seek employment elsewhere, and lowered the standard of the teachers and the local trustees. It also affected the efficiency of the circuit superintendents and compelled several of them to bow their heads to the scrip ring, or to look for other employment. In such cases a removal from office for inefficiency carried with it no remedial effects.

Under the Democratic administration the schools were closed during the years 1874 and I875, and the attendance in 1876 was only 8 per cent of the school population, ${ }^{9}$ but from that time onward it gradually increased from year to year until in 1890 it had reached about 50 per cent of the school population, which shows that the hunger among the masses for education-a hunger that was so clearly manifested during the first scholastic year of my administration in $1869-70$-in spite of all adverse conditions and plundering of the school funds under the Democratic régime, had not abated. The year I 870 remained the high-water mark in school attendance for a period of at least twenty years.

I trust that this hunger that I have spoken of will so grow in intensity as to compel the Democratic government, as now administered, to change its whole policy of antagonism to the education of the ignorant masses. A party founded upon the ignorance of its supporters may prevail through the corruption of the ballot-box, but it never can, in my judgment, under free and fair elections where both parties have proper representation on the election boards, - a representation that has been ab- 
solutely denied the Republican party in Arkansas by the Democrats since their advent to power in I 874 down to the present time, a period of forty years.

\section{ARKANSAS INDUSTRIAL UNIVERSITY}

Kindred to this question was the establishment of the Arkansas Industrial University, which owes its origin to the act of the Legislature, approved March 27, $187 \mathrm{I}^{10}$ The passage of this act was soon followed by the appointment of the Board of Trustees provided for by it, and the city of Fayetteville, having subscribed the necessary lands for the site and $\$ 100,000$ in bonds, was selected for the location of the University.

For the information of the reader as to the grant of land made by the general government for this purpose, and the date of the formal opening of the institution, and the preliminary measures resulting in the receipt of the land scrip, I extract the following statements from an address ${ }^{11}$ made by Gen. A. W. Bishop, June 22, I872, at the formal opening of the Universitywhich, I believe, are correct:

"By an act of Congress approved July 23, I 866, the time within which a State might take and claim the benefits of the act of July 2, I 862 , was extended five years, and the formal assent to it and acceptance of its provisions by the State of Arkansas was made on the 3 Ist of January, I 867 .

"On the I 2th of February in that year a certified copy of the act of acceptance by the State was filed in the office of the commissioner of public lands, a fact that fixed the date from which the five years began to run, before which expiration at least one college must have been established. On the 8th of February, when thirty were in attendance, the executive committee of the Board 
of Trustees telegraphed to the Secretary of the Interior that it had been formally opened. Its right to the congressional donation was now completely and properly asserted, but upon attempting to obtain it we were met with this objection from the Secretary; that we could not have it until the State of Arkansas should pay an indebtedness due from it to the trust fund of the Chickasaw Indians, amounting now, principal and interest, to at least $\$ 250,000$, and as security for the payment of which the government held bonds of the old State Bank.

"Shortly after Arkansas was admitted into the Union, it borrowed from this fund a large sum of money. On the first day of January, I 842 , the amount of unpaid principal was $\$ 90,000$. $U p$ to that date the interest had been met, but since then nothing has been paid, either of principal or interest, and the sum that I have mentioned is now due. The Secretary informed us, however, that if Congress would authorize him to receive the new funded bonds of the State for the bonds held by him, funding principal and interest, he would deliver the old bonds and issue college scrip.

"To that end a bill was introduced in the Senate in January last, and in March another bill in the House of Representatives, that contemplated the issuance of the scrip without any reference to the payment of this debt due from the State.

"The House bill, introduced by the Hon. James M. Hanks, of Helena, passed that body near the close of the session, and taken to the Senate was there the subject of an animated discussion that resulted in an amendment to the effect that this scrip should not be delivered to the authorities of the State of Arkansas until the State should have made some satisfactory arrangement by which the bonds of the State, principal and interest, now held by the United States as Indian trust funds, should be funded in the new bonds of the State, authorized to be issued for this purpose. This, as was announced on the floor of the Senate by Senator Clayton, the State is 
ready to do, and to use his language, 'The very moment the Secretary of the Interior comes forward and proposes to have these funded the State authorities will do it.'

"With this amendment, the bill passed the Senate the day of the adjournment of Congress, and being hurried into the House, where it was compelled to go in consequence of this amendment, it was there, through the indefatigable exertions of Mr. Hanks, and amid the hurry and confusion of the closing hours of Congress, pressed to a vote and the measure is now a law."

This institution has in the main proved a success, and with ample buildings, lands, and other facilities, it offers to over 600 students now in attendance unusual facilities for the acquirement of an education in the arts and sciences, including scientific agriculture and the best methods of industrial pursuits. This number of students does not include the attendance of the branches located at Little Rock and Pine Bluff.

I believe that the establishment of the branches of Law and Medicine at Little Rock was a mistaken policy, and that it would have been wiser had all branchesexcept, perhaps, the colored branch at Pine Bluff-been maintained at Fayetteville, subject to the general supervision of the proper officers, whose duties require them to reside there.

To the prompt action of the Government of i 868 are due the life and the vitality of an institution that was so long neglected by preceding State Governments. If it has not always realized the full expectations of its friends, the failure is perhaps attributable to the great evil of injecting politics into its management. The school interests are those of the entire people of Arkansas, and should be kept absolutely free from all political influences. 


\section{FOOTNOTES FOR CHAPTER $\mathbf{X}$}

${ }^{1}$ Arkansas House Journal, i 860, p. IO2.

2 Report of State Superintendent of Public Instruction, Ark., I 889-9o, p. 20.

${ }^{3}$ Arkansas House Journal, 1 868, pp. 296-299.

${ }^{4}$ Arkansas House Journal, I 87 I, pp. 27-28.

${ }^{5}$ Report of State Superintendent of Public Instruction, Ark., I 868-70.

${ }^{6}$ P. 222.

${ }^{7}$ Report of State Superintendent of Public Instruction, Ark., I 889-90, p. I9.

${ }^{8}$ Gantt's Digest of Arkansas Statutes, Sec. 2782, p. 53 I.

${ }^{9}$ Report of State Superintendent of Public Instruction, Ark., I $887-88$.

${ }^{10}$ Arkansas Senate Journal, I87 I, pp. 345 and 373.

11 Published in Daily Republican, July 12, 1872. 


\section{CHAPTER XI}

\section{STATE AID TO RAILROADS}

In my first message to the Legislature, on the subject of "State Aid to Railroads," I used the following language :

"A railroad bill should be passed before you adjourn which will provide for the loaning of the credit of the State to such roads as are now, or may hereafter, be incorporated, which shall be shown to be of sufficient benefit to the State to justify such loan, and which may not have received from the general government, by grant of lands or otherwise, sufficient assistance to insure the completion of the same without the aid of the State."

The Legislature promptly acted on my recommendations by the passage in both Houses, with practical unanimity, of a bill that was approved July $2 \mathrm{I}, \mathrm{I} 868 .^{2}$ This most excellent and well guarded measure, involving the loan of the State's credit, was in accordance with the provisions of the Constitution, submitted to the people for their consideration at the general election of November 3 , I 868 , when it was ratified by a large majority. Less than six thousand votes were cast against it, and it immediately went into full effect.

The Board of Railroad Commissioners therein provided for was promptly organized and, from time to time, in strict conformity with the law, granted State Aid to the following railroad companies: 
RATE

\section{ROAD MILEAGE PER MILE AWARD}

Memphis \& Little Rock

R. R. Co........II20 \$10,000 \$1,200,000

Little Rock, Pine Bluff \&

New Orleans Railroad

Company .......... I20 \$15,000 \$1,800,000

Mississippi, Ouachita \&

Red River Railroad

Company ......... I 30 \$I $5,000 \quad \$$ I,950,000

Little Rock \& Ft. Smith

R. R. Co........ I50 \$10,000 \$I,500,000

Little Rock \& Helena

R. R. Co......... 30 \$I 5,000 \$ 450,000

Cairo \& Fulton Railroad

Co. ........... 300

$\$ 10,000$

$\$ 3,000,000$

$\$ 9,900,000$

The railroad companies that finally participated in the issue of the State Aid Bonds during my administration were the first four mentioned in the above enumeration. The control of the Cairo and Fulton Railroad Company was purchased from the B. F. Rice Syndicate by H. C. Marquand and Thomas Allen, as shown by an affidavit made by Marquand under date of September I 8, I 872, and published in the Gazette, October 8th of the same year. The amount paid the Rice Syndicate for the franchise was $\$ 500,000$. The immense grant of land by the United States to this company gave it great value, and as this new proprietorship had ample funds at its command it wisely relinquished the State Aid that had been granted under the Rice ownership, and the road was completed with reasonable dispatch.

The Memphis and Little Rock; the Little Rock and Fort Smith; the Mississippi, Ouachita, and Red River 
Railroads, and a line running from Little Rock to the Mississippi River, called the Little Rock and Napoleon Railroad, were ante-bellum corporations. After the war they were all re-organized under new ownership, the first three retained their original names and the Little Rock and Napoleon Railroad was called the Little Rock, Pine Bluff, and New Orleans Railroad. Later, under the consolidation hereafter referred to, it became a part of the Little Rock, Mississippi River, and Texas Railroad.

At the time the State Aid Bill was passed there were only forty-five miles of dilapidated railroad in the State. The railroad companies were bankrupt and unable to procure credit. Notwithstanding the opposition of the Democratic party that had developed, and its false, malevolent, and constantly repeated misrepresentations as to the manner in which the law was being executed, the wonderful stimulus given to the construction of railroads under this Act will be apparent when I state that from the date of the first issue of bonds on April 20, I 869, to the date of the consolidation of the Little Rock, Pine Bluff, and New Orleans and the Mississippi, Ouachita, and Red River Railroad Companies in the fall of I 873 , three hundred and fifteen miles of road were built by the aid of the State alone, and were then in operation.

Throughout the entire period of the operations of this law, until it ceased to be effective by the repeal by the Democrats, on May 29, I874, of the law providing for the payment of interest on the State Railroad Aid Bonds, the total mileage built with the bonded aid of the State was four hundred and forty-five miles, which was 63 per cent. of the total mileage of all the roads built in the State within that period.

During the operations of this law some confusion arose in the public mind, perfectly honest in many cases, 
because of the improper use of the word "award" instead of "grant," which was used in the law. When it was announced in the newspapers that a certain road had been "awarded" State Aid it was understood by some persons that the language meant that the road had actually received State Aid, and that no other conditions were required. The word "award" is nowhere used in the law, and the granting of State Aid and the issuance of bonds were two separate and distinct official transactions. ${ }^{3}$

Poor's "Manual of Railroads," which is accepted as authority on railroad matters, states that under five years of Republican rule there were seven hundred miles of railroad built in Arkansas. After the Democrats came into power, with all their boasted prosperity, it took them nine years to build as many miles. With the exception of the Cairo and Fulton Railroad none of this construction could have been accomplished at that time without State Aid.

In support of this statement I quote as follows from a letter from C. G. Scott, President of the Little Rock and Fort Smith Railroad Company, to the Gazette, September 4, I87 I :

"I am satisfied that without this State Aid the road could not thus far have been completed, and indeed doubt that without State Aid anything at all could have been accomplished by our company."

R. C. Brinkley and B. D. Williams-respectively president and superintendent of the Memphis and Little Rock Railroad Company-frequently assured me that on account of the great expenses caused by the deeply overflowed regions of the Cache River and the lands between the St. Francis and Mississippi Rivers their road could not have been built without the State Aid. I know 
from actual experience that not one mile of railroad on the two roads that formed the consolidated line of which I afterward became president could have been built without this aid from the State.

Other important roads doubtless could have been built with this State Aid, had it not been for the demoralizing effects of the panic of 1873 and the constant efforts of the Democracy through its organ, the Gazette, and other agencies to ruin the State's credit.

In this connection I quote the following article from the Little Rock Republican, of May 24, I87 I :

\section{"A SLANDER REFUTED}

"The Gazette, yesterday morning, editorially referred to a speech recently delivered by one Fulton [a negro] and declared that he had said:

"He looked upon Clayton as the worst man in the State, and that at the time the articles of impeachment were presented against him, General Brayman, the president of the Cairo and Fulton Railroad, had a letter from Clayton in which he proposed to Brayman that he would issue bonds to that road if Brayman would pay ten per cent of the amount issued, and yet the articles of impeachment were withdrawn.'

"In order that the public may know the grounds upon which the Gazette bases its indorsement of the miserable slander to which it gives prominence, we invite attention to the following letter from Gen. M. Brayman, which effectually settles the matter:

"Little Rock, May 23, i 87 i.

"Editor Republican: I find in the Gazette of this morning a statement of E. A. Fulton, in Drew County, that at the time the articles of impeachment were presented against Governor Clayton, 'General Brayman had a letter from Clayton in which he proposed to Brayman 
that he would issue bonds to the road, if Brayman would pay ten per cent of the amount issued.'

"Allow me to say in connection with this statement that I never had such a letter, nor any knowledge of its existence.

\section{"Respectfully, \\ "(Signed) M. Brayman."}

On account of the high standing and well-known character of General Brayman, his statement, when considered along with the charge of the irresponsible negro Fulton, should be sufficient,- to say nothing of my own positive denial. When repeated at home charges of this character had but little effect, but when constantly reiterated in the money markets of New York and elsewhere, - mostly through the Associated Press Agency, controlled by the Gazette,- - they were very damaging to the public credit.

On August 27, I 87 I, the following article appeared in the columns of the Gazette:

\section{“OUR RAILROADS-STATE AID}

"It is a well-known fact that owing to overanxiety to complete the roads, or for some other cause, our late Governor was not as careful in his issue of bonds to our railroad enterprises as he should have been. $\mathrm{He}$ gave the bonds to the roads in many instances, expecting the roads to follow; these bonds were thrown on the New York market, as much realized from them as could be obtained, some little work done, and the enterprises brought to a standstill. This is true particularly of the Little Rock, Pine Bluff, and New Orleans, and the Mississippi, Ouachita, and Red River Railroads. Just exactly how the affairs of these two corporations now stand we are not advised." 
I admit that I was very anxious for the success of those' two enterprises, but I emphatically deny that a single bond was issued by me to either company which it had not the lawful right to demand. Considering the obstacles that were constantly placed in the way, every mile of railroad to which bonds were issued during my administration was built and operated within a reasonable time. I have in my possession, for each issue made by me, an exact duplicate of the original receipt and affidavit of the president and other officers, as required by the following provision of the State Aid Law : ${ }^{4}$

"Be it further enacted, That thereupon the Governor, or the person filling for the time being the executive office, shall issue to the President of said Company the bonds of the State of Arkansas, bearing the seal of the State, attested by the Secretary of State, as provided in section I hereof, upon the completion and preparation for the iron rails of each succeeding ten miles or more, until the entire line or lines of road of said railroad corporation shall be completed. The President of such railroad company shall file his official receipt for each issue of bonds, accompanied by the affidavit of himself and at least four directors, that the bonds, or the avails of them, shall be disposed of solely for the purpose of providing for the ironing, equipping, building, and completing said road."

For the information of the reader I here insert copies of the original receipt and affidavits received by me, in compliance with the above provision of law, covering the last issue of bonds made during my administration to the Little Rock, Pine Bluff, and New Orleans Railroad Company: 
"I, James M. Lewis, President of the Little Rock, Pine Bluff, and New Orleans Railroad Company, do hereby solemnly swear that the fifth section of ten consecutive miles of said railroad has been graded, bridged, furnished with ties, and made ready for the iron rails, in accordance with Act of the General Assembly of the State of Arkansas, approved July 2 I, I 868 , entitled, 'An Act to Aid in the Construction of Railroads.'

$$
\text { "(Signed) James M. Lewis, President. }
$$

"Subscribed and sworn to before me this seventeenth day of January, I $87 \mathrm{I}$.

"(Signed) Jno. McClure, Associate Justice,
"Supreme Court of Arkansas.

"State of New York,

"City And County of New York.

"I, Jackson E. Sickels, director of the Little Rock, Pine Bluff, and New Orleans R. R. Co., do solemnly swear that the bonds of the State of Arkansas, about to be issued to said railroad company, or the avails of them, shall be used solely for the purpose of providing for the ironing, equipping, building, and completing said company's road.

"(Signed) Jackson E. Sickels, Director.

"Sworn to before me this roth day of January, I87 I.

"(Signed) C. Wesley Turrell,

"Notary Public, N. Y.

"I, Thomas M. Bowen, director of the Little Rock, Pine Bluff, and New Orleans railroad company, do hereby solemnly swear that the bonds issued to said company by the State of Arkansas on the completion of the fifth section of ten consecutive miles of the roadbed of said railroad shall be disposed of solely for the purpose of providing for the ironing, equipping, building, and completing said road in accordance with an Act of the 
General Assembly of the State of Arkansas, entitled 'An Act to Aid in the Construction of Railroads,' approved July 2 I, I 868 .

"(Signed) Thomas M. Bowen, Director.

"Subscribed and sworn to before me this 17 th day of January, I 87 I.

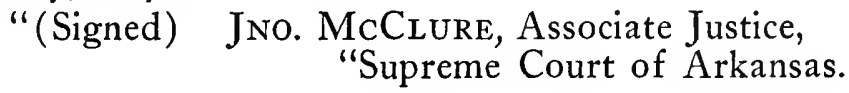

"I, O. P. Snyder, director of the Little Rock, Pine Bluff, and New Orleans railroad company, do hereby solemnly swear that the bonds issued by the State of Arkansas to said company on the completion of the fifth section of ten consecutive miles of the roadbed of said railroad, shall be disposed of solely for the purpose of providing for the ironing, equipping, building, and completing said road in accordance with an Act of the General Assembly of the State of Arkansas, approved July 2 I, I 868, entitled 'An Act to Aid in the Construction of Railroads.'

\section{"(Signed) O. P. Snyder, Director.}

"Subscribed and sworn to before me this seventeenth day of January, $187 \mathrm{I}$.

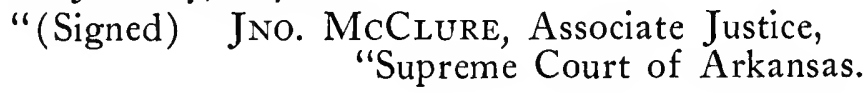

"I, S. W. Mallory, director of the Little Rock, Pine Bluff, and New Orleans Railroad Company, do hereby solemnly swear that the bonds issued to said company by the State of Arkansas on the completion of the fifth section of ten consecutive miles of the roadbed of said railroad shall be disposed of solely for the purpose of providing for the ironing, equipping, building, and completing said road in accordance with an Act of the General Assembly of the State of Arkansas, approved July 


\section{THE AFTERMATH OF THE}

2 I, I 868, entitled 'An Act to Aid in the Construction of Railroads.'

"(Signed) S. W. Mallory, Director.

"Subscribed and sworn to before me this I 7 th day of January, A. D. I87 I.

"(Signed) JNo. McClure, Associate Justice, "Supreme Court of Arkansas.

"I, James M. Lewis, President of the Little Rock, Pine Bluff, and New Orleans Railroad Company, do hereby solemnly swear that the bonds issued to said company by the State of Arkansas on the completion of the fifth section of ten consecutive miles of the roadbed of said railroad shall be disposed of solely for the purpose of providing for the ironing, equipping, building, and completing said road in accordance with an Act of the General Assembly of the State of Arkansas, approved July 2 I, I 868, entitled an 'Act to Aid in the Construction of Railroads.'

"(Signed) Jas. M. Lewis, President.

"Subscribed and sworn to before me this 17 th day of January, A. D. I 87 I.

"(Signed) Jno. McClure, Associate Justice, "Supreme Court of Arkansas.

"Received, Little Rock, Arkansas, January I7, I87 I, of Powell Clayton, Governor of the State of Arkansas, One Hundred and Fifty State Bonds of the denomination of One Thousand Dollars each, it being amount of State Aid due the Little Rock, Pine Bluff, and New Orleans Railroad Company on completion of fifth section of ten consecutive miles of roadbed of said Railroad, said bonds numbered from 601 to 750 inclusive. "(Signed) Jas. M. Lewis, President."

The whole purpose of the State Aid Bill, as set forth in the law above quoted and in the affidavits reproduced, 


\section{CIVIL WAR, IN ARKANSAS}

was to aid the railroad companies in the purchase of rails and other equipment.

Some time later the Little Rock, Pine Bluff, and New Orleans Railroad-not having complied with the provisions of Section 7 of the State Aid Law ${ }^{5}$ requiring the payment of taxes, or interest, under the provisions of Section $8,{ }^{6}$ - was sequestered by the State Treasurer, and Col. A. H. Ryan was appointed receiver. No better appointment could have been made. He was faithful, industrious, and frugal, and he worked energetically for the completion of the road to Pine Bluff, where a large amount of business was awaiting the establishment of train service to that point.

A wagon service was put on by the merchants of that city to cover the few miles of unfinished road then in the course of construction, which added very materially to its revenues; and under the operations of the State Aid Law and this increased income the road was completed between the eastern terminus on the west bank of the Mississippi River and the city of Pine Bluff, and put into successful operation.

Under the act providing for the consolidation of railroads, ${ }^{7}$ the Little Rock, Pine Bluff, and New Orleans and the Mississippi, Ouachita, and Red River Railroad Companies were, in the fall of I 873 , consolidated under the title of the Little Rock, Mississippi River, and Texas Railroad Company. My official services to the State having terminated, I became president, with Jackson E. Sickels as vice-president and treasurer of said consolidated lines.

James M. Lewis and Thomas M. Bowen had been the respective presidents of the two companies prior to that time, and as neither of them had had any previous railroad experience they had made a rather sad mess of affairs. I accepted the position very reluctantly, know- 
ing that I was taking up burdens that they were only too eager to lay down, but I finally did so, principally for the reason that I was personally interested in the success of the Little Rock, Pine Bluff, and New Orleans railroad, which was the main portion of the consolidated lines. It ran through my plantation on ground that I had donated to it, and where was then established "Linwood," one of its most important stations, thus giving me constant and reliable shipping facilities to New Orleans; whereas previously the uncertain navigation of the Arkansas River sometimes delayed shipments for months and even years. In addition to plantation facilities it enabled me to establish a store and shipping agencies at "Linwood," and also a sawmill adjacent to the depot, on the edge of a large body of fine cypress timber, affording the means of shipping the product to a profitable market.

With the faithful Ryan in charge, I now joined, in New York City, Jackson E. Sickels, who was working on a project for the continuation of the road to Little Rock, a distance of forty-three miles, and for the extension of the Mississippi, Ouachita, and Red River line to Camden. He was negotiating with one Dr. Ryder, who in turn was negotiating with a foreign syndicate amply able to finance this project. As we were nearing the consummation of our purposes dark financial clouds gathered in the east, which soon developed into the great panic of 1873 , and, along with more meritorious enterprises all over the country, our work came to naught.

This left the Railroad Company not only subject to the State's claim for the non-payment of the taxes [interest] heretofore referred to, but what was still worse, in default of the interest on its first mortgage bonds, a number of which had been purchased by others than the original owners of the property. This resulted, during 
the widespread financial crash, in the foreclosure and sale of both properties. Under these very discouraging conditions, the stockholders, being men of moderate means and having exhausted to a great extent their private resources, allowed the Little Rock, Pine Bluff, and New Orleans and the Mississippi, Ouachita, and Red River Railroads to be separately foreclosed and sold at almost confiscatory prices.

Could they have borrowed money under those conditions, it would have been vastly to their interests to have competed with the purchasers who bought the property, but the question at that particular time was, where to get the money! Soon after the panic ceased the new owners of the properties constructed the line from Pine Bluff to Little Rock and extended the Mississippi, Ouachita, and Red River line to Warren, the county seat of Bradley County.

In closing this chapter I desire to say that I was frequently criticized for my actions in connection with the issuance of bonds to aid in the construction of the various railroads and, while I was never openly charged with appropriating any of them for my own use, it was strongly hinted that I had been well paid for the aid I had given to the railroads.

I will state positively that until the year 1892 , when ten of them came into my possession, I had never owned nor held a single bond that had been issued to aid in the construction of railroads. Those bonds were received by me in the following manner:

After my brother, John M. Clayton, had been assassinated, my brother Thomas and I entered into an agreement to bear equally the expenses of maintaining and educating his minor children. I placed two of them in school and took the other four with me to the hotel in Eureka Springs where I resided. 
My brother was slow in meeting his half of the expenses and I advanced his share until he owed me \$1,500. During the year I892 I visited him at Chester, Pa., and while I was there I suggested to him that he was behind in his payments. He had at some previous time invested \$10,000 in the State Aid bonds issued to the Memphis and Little Rock Railroad Company, and he suggested that I take his investment and relieve him from all future responsibility on behalf of John M. Clayton's children.

Although in 1874 the State Legislature had passed an act relieving the railroad companies of the interest obligations on the bonds issued to them, which was followed in 1883 by a constitutional amendment repudiating the bonds themselves, and I realized that my brother's investment was absolutely worthless, I agreed to his proposition and he immediately turned over to me the ten bonds.

These bonds remained in my possession until just before I returned from Mexico to the United States, when they were stolen. I have always supposed that some of the Mexican employees took them and, knowing that they were of no value, I made no particular effort to recover them.

These were the only bonds issued to aid in the construction of railroads that were ever in my possession.

\title{
FOOTNOTES FOR CHAPTER XI.
}

\author{
${ }^{1}$ Arkansas House Journal, I 868, p. 295. \\ 2 Arkansas Laws, I868, pp. I 48-1 53. \\ "Arkansas Laws, I868, pp. I49-1 50, Secs. 4 and 5. \\ 4 Arkansas Laws, I868, pp. I50-I 5 I, Sec. 6. \\ ${ }^{5}$ Arkansas Laws, I 868, p. I5I. \\ ${ }^{6}$ Arkansas Laws, I 868, pp. I5 I-I 52. \\ ${ }^{7}$ Arkansas Digest of Statutes, Gantt, pp. 866-867, Sec. 4969.
}




\section{CHAPTER XII}

FUNDING THE STATE DEBT

As the loan of the bonds of the State in aid of the construction of railroads depended to a great extent for its efficacy upon the power of the State to establish first its financial credit, I shall now undertake to give a brief history of the Real Estate and State Banks and the funding of their indebtedness.

In 1836 the State of Arkansas was admitted into the Union, and on the I2th of September ensuing the first General Assembly convened. Its first acts were to charter the Real Estate and State Banks. I shall first take up the history of the former.

The charter provided for the loan to this Bank by the State of $\$ 2,000,000$ of its six per cent. bonds. Perhaps never before in the history of banking operations was such a system adopted,- - a system whereby a few favored individuals were created stockholders by the act, and enjoyed the special privilege of bank ownership without contributing anything themselves. And these individuals, by the loose character of their charter obligations, refused successfully for about sixteen years to give any information whatever to the Executive and Legislative Departments of the State concerning its operations.

The Bank, with an inadequate supply of coin in its vaults, opened its doors December I 2 , i 838 , upon a specie payment basis, which was suspended less than a year thereafter. This was followed about fourteen 
months later by the default of its interest payments on the bonds loaned to it by the State, on which bonds the State also soon after defaulted in its interest payments. These defaults continued for twenty-six years, when the Republican administration funded the entire indebtedness.

The reader will bear in mind that the first president of the Real Estate Bank was John Wilson, who was also Speaker of the House of Representatives. He was the originator of the substitution of the bowie-knife for the gavel as the emblem of his authority. How long he occupied this dual capacity I am not able to ascertain, but it is evident that his influence with the Bank and the Legislature continued for a long time.

In view of the Bank's arbitrary actions, before referred to, a full history of this stupendous swindle, improperly designated a "Bank," never has been and never can be fully made known by authentic history. For the further information of the reader, I invite his attention to the following extracts from official sources:

From Governor Yell's message of I $840:^{1}$

"The bonds were hypothecated in September, I 840, but the fact did not leak out till July, I84I; and it was not the only important fact concealed from the Legislature. The statement of the condition of the bank was drawn up in such a way that it was impossible to tell from it whether there was one dollar or one hundred thousand dollars in specie in its vaults."

From the message of Governor Adams, dated November 5 , I $844:^{2}$

"The condition of the Real Estate Bank is unknown to the community whose interest is so deeply concerned in its management ..... Whether the property and assets of the bank are applied to the legitimate objects of its 
creation, I am unable to say .... I have but little doubt, however, that the want of confidence in the operations of the bank, as manifested in various portions of the State, proceeds more from the fact that all information in relation to it has been kept in the hands of a few individuals than from any corruption in its administration. The history of the bank already presents the most extraordinary picture ever exhibited to a free people. In the first place, a public corporation is created by the solemn act of the legislative department of the Government, involving the rights and privileges of individuals as well as the State. In the next place, the act of incorporation giving existence to the bank is destroyed by an ex parte operation of a few individuals, by which a deed of assignment was made to a few men denominated residuary trustees, whereby the assets of the bank of every description were transferred into the hands of the said residuary trustees and their officers. From that period the operations and management of the bank have been involved in profound mystery."

\section{From Governor Drew's message of $1846:^{3}$}

"The limited knowledge which, in common with the public, I possess of the affairs of the Real Estate Bank does not enable me to add much to the suggestions of my predecessor. I concur with him as to the propriety of an investigation into the affairs of that institution. It is a monstrous proposition which I have heard advanced, that the legislature had no rightful authority to examine into the affairs of this institution."

From the message of Governor Roane, November, I $850: 4$

"Since the date of her assignment the Real Estate Bank has been a sealed book to all those uninitiated in the banking operations of the present day, whether pri- 
vate individuals or public officers, save so far as the native politeness and gentlemanly bearing of her worthy secretary may prompt him to gratify the curious and enlighten the public. History, prior to this date, unfortunately however for the State, reminds us of a few facts in connection with this mystic monument of modern banking.

"In I 836 and I 837 the State of Arkansas issued I, 530 bonds of \$I, OOO each, which were sold by the Real Estate Bank at their par value; subsequently 5 oo other bonds for a like amount were issued to this bank and by her hypothecated for the sum of $\$ 122,389.77$, realizing in all from the sale of these bonds $\$ 1,652,389.77$, which was to constitute her capital for the purpose of banking. We also know that after discounting heavily for a time she suspended payment, closed her doors, and made an assignment of all her assets, appointed trustees to take charge of them, with a clerk to keep the accounts and an attorney to advise and control them, and then provide for their payment.

"Here the authentic history of this institution ceases. What accounts may have reached us of her transactions wear more the gaudy apparel of romance than the plain habiliments of reality. And although the State has such a deep interest in the correct management and final settlement of this institution, she sets her authority at defiance, and claims the right to close her doors in the face of her officers, acknowledging that when she shall be condemned to lay down the heavy debt which she has contracted the State must take it up."

From the message of Governor Conway, November 4, I $856:^{5}$

"Notwithstanding all this, if the people of the State do not ultimately obtain full and correct information of the conditions of the Bank by means of the suit now pending, it will not be the fault of the executive. To the 
General Assembly the executive appeals for the necessary discretionary powers and means to enable him to have this suit faithfully and vigorously prosecuted, so that the laws on the subject may be effectively executed. Then the true condition of the bank will be known, the interests of the State and stockholders well looked to, and the mysteries which have so long hung around the institution will be unveiled, and it is to be hoped that the day will never again come when the executive of the State, in his message to the General Assembly, will be compelled to compare an institution like this, involving the interests, credit, and honor of the State in millions of dollars, to a 'sealed book,' so far as its transactions are known to the authorities of the State or the people."

At the session of the Legislature of I 852-53 an act was passed providing for the appointment of a joint committee to inquire into the affairs of the Real Estate Bank. From the report of this committee, made in I 856 , I give the following extracts:

"At the session of I 852-53 the legislature resumed its efforts to arrive at a knowledge of the condition of the bank, and appointed a committee to inquire into its affairs." 6

"An act was passed January the I 5 th, I 855 , 'to establish a separate court of chancery at the seat of Government, so that the causes of the State, including that against the trustees and officers of the Real Estate Bank, and those of individuals, may be determined as early as practicable.'" 7

"In the session of I 844-45 an amendment to the Constitution was proposed, in which it is declared that 'No bank or banking institution shall be hereafter incorporated or established in this State,' which amendment was unanimously adopted by both houses at the session of I 846-47." 
Under the authority of the Legislature of I 856 full powers were granted the Governor to investigate thoroughly the conditions of this bank, among which powers was the authority to appoint two expert accountants to aid him in his investigation, which resulted in the appointment of Messrs. William M. Gouge and William R. Miller. Mr. Gouge had a long record of service in the sub-treasury department at Washington, D. C. Mr. Miller was afterward Governor of the State.

Their able report upon the condition of the bank, rendered to Governor Conway on October 20, I 856 , is full of important information, among which is the fact that none of the bonds of this bank were held by citizens of Arkansas, as shown by the following extract: ${ }^{9}$

"Of the amount due for bonds, upwards of $\$ 500,000$ was due to the United States Treasury Department for an investment made by it of the funds of the Smithsonian Institute. The residue was due to various parties in the Atlantic States and Europe."

Therefore, no one in Arkansas raised his voice against the failure of this bank and the State to preserve the credit of Arkansas. The United States was responsible for the payment of the interest on the trust fund investments, and the other bonds were owned by persons in whose interest no one seemed to be concerned.

The second act of the Legislature of I 836 was to incorporate the State Bank of Arkansas, to which a loan of \$I,000,000 of State bonds was made. This bank commenced business in August, 1837, with a paid up capital of $\$ 396,000$, which was increased by November 6 to $\$ 4 \mathrm{I} 3,105.29$. It began specie payment in January, I 839, and suspended in November of the same year. On the $22 \mathrm{~d}$ of December, 1840 , an act was passed ${ }^{10}$ which provided that the State Bank and its branches should re- 


\section{CIVIL WAR, IN ARKANSAS}

sume and continue specie payments simultaneously with the banks of Louisiana, Tennessee, and Alabama, and that it should not again suspend under any circumstances. This act did not prove effective, however, and on January $31,1843,{ }^{11}$ an act was passed to place the State Bank in liquidation.

About this time the State Bank defaulted in the payment of interest on the State bonds loaned to it, and the State was left to "hold the bag," with nothing in it to meet its interest obligations.

From the report of the Joint Legislative Committee on Banks, dated December 23, I846, I quote as follows:

"The State mainly lived on the means of the bank [The State Bank] from its commencement, and as long as it had a dollar." 12

I shall now proceed to narrate what occurred in relation to both banks during the term of my administration as Governor of Arkansas. In my message to the General Assembly, November 24, r868, after referring the Assembly to the report of Hon. J. R. Berry, Auditor of State, in which he named the amount of the public debt on account of the Real Estate and State Banks of Arkansas, I made the following recommendations: $:^{13}$

"I regret that the disturbed condition of the State and the pressure of official business have prevented me from giving the matter sufficient investigation to enable me to lay before you any terms of adjustment.

"I would respectfully recommend that you take steps toward the funding of the indebtedness by the appointment of a suitable person as commissioner to negotiate with the holders of the bonds; and, upon his action being approved by the proper authority, that the State Auditor and State Treasurer be authorized to issue new bonds and cancel the old ones." 
After much discussion in the House, growing out of the provision that required the funding of the full amount of the Real Estate and State Bank bonds, including the Holford bonds, both Houses passed the bill, which was approved April 6, I $869 .{ }^{14}$

I selected the American Exchange National Bank of New York City as the fiscal agent of the State, to conduct the exchange of new bonds for a corresponding amount of the old indebtedness. In order that there should be no chance for the perfected bonds to be intercepted in transit from Little Rock to New York City (means of communication by express at that time being very imperfect) I had them duly executed with the exception of my signature as Governor, which I supplied in New York City, where I turned them over to the fiscal agent and took his receipt therefor.

Immediately thereafter I issued the following notice:

\section{"Executive Department, State of Arkansas, "Little Rock, August i 2, i 869.}

"To Whom It May Concern: NOTICE is hereby given that I am prepared to carry into execution the provisions of an act of the Legislature of the State of Arkansas, entitled 'An Act to Provide for the Funding of the Public Debt of the State.' All persons holding the old bonds of the State can have the same, with accrued interest thereon, exchanged for new bonds by presenting them to the American Exchange National Bank, in the city of New York.

$$
\text { "(Signed) Powell Clayton, }
$$

Soon after the passage of the Act it was whispered around that money had been corruptly used in the Legislature for that purpose, and my attention was specifically called to the peculiar features of the Holford Bond 
transaction. Having resolved not only to investigate the charge of corruption, but also to examine more fully into the history of the Holford Bonds, I gave the fiscal agent instructions to proceed with the exchange of all bonds except, for the time being, those known as the Holford Bonds, and to hold the latter in abeyance until further instructed. This action upon my part was severely criticised in the following communication, published by the Gazette, September 5, I869, signed "Republican":

"Governor Clayton knows very well that he will, sooner or later, fund these bonds, because the law allows him no discretion in the premises, and a bill which gave him that discretion was voted down last winter. But he also knows that the present is a critical period in the negotiations for money to build the roads, and that by this act of his he can impair the credit of the State and suspend the progress of improvement. He knows that this will involve pecuniary loss to many, and this is to him an argument that pecuniary means will be adopted to avert the evil; and these pecuniary means, he trusts, will fatten himself and feed his little nest of obscene birds ....

"In this matter he is acting in wretched bad faith, and his motives add all the moral turpitude of personal dishonesty to official malfeasance. $\mathrm{He}$ is thus making a most pitiable exhibition of the depravity of human nature, and demonstrating to the world how low a man can sink himself in the debasing pursuit of sordid gains."

This Gazette article was followed by others still more scurrilous. It turned out that they were all instigated by Mr. Peak, the former editor of the Republican, who was to receive for his services a certain compensation from the Ft. Smith Railroad Company, for the payment of which he afterward brought suit and thus the whole 
transaction came to light. In this connection I quote from the Gazette of October 24, I872, as follows:

"SUB ROSA. ... In like manner all our well intended efforts to keep Mr. Peak quiet in his little bed have failed, and he still wants to engage in 'mutual inquiry and discussion.' The Journal of Monday contains another card over his signature. He appears oblivious of the ridiculous (to say the least) attitude he presents to the public. Strange to say, he takes a rosecolored view of his situation. Having previously declared that, 'It is not true that, as the old editor of the Republican, or in any other manner, I favored the Holford Bond Swindle, but, on the contrary, as is well known to every man who took an active interest in that measure, I was its earliest and most earnest and persistent opponent,' he now admits that he brought suit for $\$ 5$,000 and recovered $\$ 500$ damages against the Little Rock and Ft. Smith Railroad Company for service rendered in writing, at their instance and request, articles to influence Governor Clayton to execute the provisions of an act of the Legislature! The act referred to was the act attempting to legalize the Holford Bond swindle! That is to say, having once, from principle alone, opposed the measure almost to its defeat before the legislature, he afterwards, for pay, agreed to write and surreptitiously procure the publication of articles in the Gazette, intended to influence Governor Clayton to execute these illegal provisions after they were put into the semblance of law!"

To have legally changed the provisions of the Act would have required a re-assembling of the Legislature, and this perhaps would have imperiled the whole measure. In obedience to the only power conferred upon me, I directed the fiscal agent to exchange the Holford Bonds just as he did the others. 
During my short absence in New York on this funding business a conspiracy was hatched between the Democratic leaders at Little Rock and some of LieutenantGovernor Johnson's supporters, which might have plunged the State into serious disturbances had not my prompt return to the Capital prevented. It was planned to have the Lieutenant-Governor take possession of the executive office under the pretext of the following provision of the State Constitution: ${ }^{15}$

"In case of the impeachment of the Governor, his removal from office, death, resignation, inability or removal from the State, the powers and duties of the Governor shall devolve upon the Lieutenant-Governor during the residue of the term, or until the disabilities of the Governor are removed."

The reader will readily discern that the Governor's removal from the State and his temporary absence on State business were two very distinctly different things. But the Democratic leaders were ready to stir up trouble under any pretext, provided they could get Johnson to take the initiative, which subsequent events show he was quite willing to do.

To show the extreme purposes of this movement, I reproduce a communication signed " $\mathrm{X}$ "- a pseudonym for Thomas C. Peak, heretofore referred to ${ }^{16}$-published by the Gazette, August I, I 869:

"It is conceded by his friends and members of the coördinate departments of the State Government that 'Governor' Clayton has gone out of the State, without giving notice to the Lieutenant-Governor, his constitutional successor in such event by virtue of the provisions of section ten of article six, of the Constitution, which declares : 
" 'In case of the impeachment of the Governor, his removal from office, death, resignation, inability or removal from the State, the powers and duties of the Governor shall devolve upon the Lieutenant-Governor during the residue of the term, or until the disabilities of the Governor are removed.'

"Arguing that the contingency contemplated has happened in the temporary removal of the Governor to New York to engage for a while in the business of a Wall Street broker, the conservative Republicans of the State have urged upon the Lieutenant-Governor, who is said to be on his way here from his home in Madison County, to assume at once the duties and authority of Governor of the State, and proceed to the arrest of the absconding Governor and such of his deputies and subordinates as have been aiding and abetting him in various violations of the Constitution, and fraudulent and treasonable practices, and hold them in arrest to answer articles of impeachment to be preferred against them by the Legislature, which, it is asserted, Governor Johnson will assemble at the capital without delay. Clayton's guilt and that of his co-conspirators can be established beyond a doubt by such an array of evidence, it is claimed by the conservative Republicans who have advised the course, that the Senate, although there is a majority of Clayton's creatures in that body of two, will be bound to convict him and deprive him of his office for the residue of his term.

"This is a bold program; but it is said that Governor Johnson has the mind and heart to carry it out without hesitation; and that the backing of an undoubted influence, formidable and irresistible, of the white and colored members of the Republican party of this State is ready to be afforded him. This is most important if true. And that it is true many circumstances go to testify. It would not only give to the Lieutenant-Governor a national reputation for pluck and enterprise, but would make him irresistible forever before the people of Ar- 
kansas; in whose estimation the oppressions and villainies of Clayton have reached an excess intolerable under any other circumstances than those which surround them at this time. This is rumor, suggested perhaps by the supposed feasibility of the plan.

"(Signed) X."

I was notified of this movement and, having completed my business in New York, I returned to Little Rock and immediately resumed my official duties. Lieutenant-Governor Johnson's home was at Huntsville, the county seat of Madison County, situated in the extreme northwestern part of the State, and could not be reached by any public conveyance; hence, it required considerable time for the two messengers to reach him, and for him to reach the Capital. To prepare the people for the commotion that would follow the success of their scheme, the two messengers sent to confer with Johnson circulated alarming and lying reports along their route, as is shown by the following extract from the Republican of August I3, I869:

"EXTRAORDINARY REVELATIONS. We received a call yesterday morning from our friend, Capt. Chas. E. Berry, sheriff of Franklin County, who arrived in the city Wednesday evening direct from his home, for the purpose of settling the taxes of his county with the Treasurer and Auditor.

"We learn from him that a great commotion was created in Ozark before he left. It seems that parties from Little Rock on their way to Huntsville reported that Governor Clayton had left the State, taking with him all the funds of the State, as well as the seal of the State, and that several county sheriffs who had not paid over were to follow the Governor and turn over to him all funds in their hands, and that Lieutenant-Governor 
Johnson was coming to Little Rock to put a stop to the robbery. The two individuals making for Madison County told the story with so much earnestness that some of the people were foolish enough to believe them. Captain Berry's bondsmen were extremely anxious about the matter, although the Captain was permitted to come to the city and make his settlement. No doubt the story was accepted as true after seeing the Lieutenant-Governor, with one of the party, take passage on the American for Little Rock.

"The story was a base slander and an outrage upon the people. Lieutenant-Governor James M. Johnson and J. E. Richardson, the friend who went after him, arrived in Little Rock Wednesday evening. (The other friend returned to this city on Saturday last.)"

The J. E. Richardson referred to was a correspondent of a Northern newspaper, and not a citizen of the State. The name of the other emissary I cannot recall.

A few days after my return Johnson appeared on the scene, only to find that all his ambitious dreams had vanished into thin air. There seemed nothing left for him to do but to tuck his caudal appendage between his legs and sneak back to his mountain home. To relieve the humiliation of his defeat, he had a small crowd assemble on the night of August I3, I869, in front of the Anthony House, under the pretext of a serenade. To this gathering he delivered in a slightly modified form to suit the occasion the speech that he would have given in its entirety had his appearance upon the scene been opportune. In this speech, by his misrepresentation of facts, he showed that he was either not well informed or was ready to circulate new lies invented for the occasion and repeat old ones that had already been exploded. The following is the Gazette report of the speech in question, under date of August I4, I 869: 
"This compliment was truly agreeable to him. He was satisfied that the people of Little Rock, with the people of the entire State, were anxious to hear from one of the officials of the State as much of the history or transactions of the Government as he was in possession of. The curiosity of the people residing outside of this city is centered in Little Rock, - to know what kind of a government we are living under.

"A party came into power in this State more than one year ago, belonging to the National Republican party; but soon after this a portion of these officers inaugurated a system known as radicalism. Another wing proposed to adhere to the national platform. But as soon as the election of last year was over those who held the highest positions in the State government undertook to dictate to the people. A few of us stood up manfully and battled for Republican principles. But the others assumed the right to dictate the policy of the party, and inaugurated a reign of terror for the purpose of coercing every honest officer in the State into a support of their infamous measures. He took it for granted that this compliment was paid to one who dared oppose their swindling operations. He was outspoken on every occasion when schemes concocted for robbing the people were proposed; he was in favor of an honest and economical administration of the affairs of the government.

"After the reconstruction laws of Congress had been accepted by the people as a fixed fact, this mighty man, Powell Clayton, declared war on the people. He opposed it. Many honest Republicans had been led astray, thinking they ought to support the State government. He too was in favor of upholding the State government, but when the officers had violated their obligations he thought it time they should be checked.

"He had been traduced by the press of the State for the past eight months and had made no reply. They had it all their own way. It is said that Johnson has sold out to the Democracy. No Democrat ever heard him 
making overtures, - but always found him for an honest administration of the government.

"You hear much talk about railroads, free schools, etc. What has been done? Bogus railroad companies have been organized, and mere adventurers,-men of straw,-given control. The people voted almost unanimously for State Aid to railroads. How was this aid dispensed? What investigations have been made as to whether the companies are competent and reliable to carry out their part of the agreement? The only question asked by those who dispensed this aid was, Will it put money in our pockets? Io per cent. is wanted. If they can get that out of the $\$ 13,000,000$ loan to the various companies, the executive and his three commissioners will be rich.

"A Voice: Fill up their carpet bags.

"The Speaker: A carpet bag would not hold it,-it will take a goods box.

"The Executive, Secretary of State, and others, it is said even with the seal of the State, go to New York and hawk the bonds of Arkansas through her streets. If the seal is in the office of the Secretary of State, any citizen has a right to ask for its exhibition. The people pay taxes and have a right to know what their servants are doing.

"Thirty-odd years ago some bonds were taken to New York, under the instruction of the Legislature, who appointed the commissioners. But under radical rule the Governor appoints his own commissioners, and goes himself to reside in Gotham while the transaction progresses. "The executive office is in Little Rock,- - not New York, - and requires the Governor to execute the duties of the same at this place. But he travels from pillar to post. By the custom that used to prevail, courtesy required that when a Governor went without the bounds of the State he invited the next officer in rank to preside in his absence. But the present Governor left without telling anybody where he was going, except those who 
were necessary to his schemes. Why was this? Why not notify the Lieutenant-Governor? The people,-by those bonds and the taxes they pay into the treasury,are interested in this question. It is obvious there was something which it was necessary to cover up. Is that radicalism? This man wields the scepter of an emperor, a despot as he is. You can tell when radical rule is upon you-the tax gatherers begin to make their appearance. But this Governor created a proxy to act in his absence, who was also Secretary of State and private secretary; and the same little Methodist preacher also holds the fat position of public printer. No wonder he had the frights and was running up and down the streets for two weeks telegraphing to his master. The affairs of State hung upon his limbs a 'world too wide.'

"If we organize a party it will not be necessary to give it another name than anti-Clayton, anti-radical, and we will be sure to win. He felt safe in asserting that at the next election the Executive now in control could not get one-tenth of the vote of all classes put together. There is general disquietude throughout the State. $\mathrm{He}$ felt it everywhere. He could read it here. All want to know what he came here for, and he proposed to satisfy them. When he first heard of the Governor's absence he expected by every mail to receive official notification of the fact. The loyal people of his county,-whom the carpet-baggers call disloyal, - insisted on his coming to the Capital. He declined until they became clamorous. They said something was wrong, and urged him to come at once and investigate what these men were doing. There is no despot that treats his subjects as does this Governor. He came here to obey the will of the people. When he arrived he found the Governor had hastened back and was occupying the executive chair. He was glad of it, and hoped he would remain at home until he learns sufficient politeness to invite his constitutional alternate to take his place when he has another speculation on hand. 
"A few of us last winter made an effort to organize a more moderate party. We proposed to remove the political disabilities of the men who pay the taxes to support the government. We were in the minority then; but he believed the good people would vote as a unit to remove every cause of complaint, of strife and prejudice that now exists, and do it in the name of the Republican party. At the time we proposed to do this we could do nothing beyond making a protest against the rascalities of the radicals. Our prediction then of what would be the policy of the Republican party has been verified in the election recently held in Virginia and Tennessee. Republicans have been elected in both who stand squarely upon the national platform. As far as we can ascertain, the President himself is in favor of removing these disabilities. Men whine about your city saying these elections are Democratic or Rebel victories; but he would say, here, as a Republican, that it was a victory to the good people of Tennessee and Virginia, to be followed by Texas and Mississippi. He believed good men could be elected all over the Southern States; and he said that it was the policy of the Republican party to remove the disabilities of everybody. It is the teaching of the Republican party. There are a set of officeholding men here who know they can do nothing if all the people are enfranchised, unless it is accomplished by fraud, martial law, setting aside of registration and elections, etc., and they want to resort to such means again to perpetuate their power,-but they must not do it.

"He had felt it his duty to give a history of his connection with the State government and the Governor's late trip. His motives would be understood. The time had come for the down-trodden people of Arkansas to raise their heads and look the men who should be their servants in the face, and be satisfied with nothing but their rights. He was sorry to see men's mouths closed, - who seem to look no higher than the throne. He pro- 
posed to look to the power behind the throne,- - the people. We have nothing to expect from the Governor. The time has come for the people and the press to be free. How is it with the Republican press? Every Republican paper which receives the patronage dispensed by the Governor is muzzled. The radical press is not the exponent of the principles of anybody but Powell Clayton, who has many of these little thumb papers scattered throughout the State. When his spies find one of them that is ready to go down a carpet-bagger, or perhaps a Methodist preacher, says to him, "Go to the Governor; get the public printing; go halves with him, and be his organ.' Unfortunately, unless the people support honest newspapers that live on their merits, it will not be long until the Governor owns the entire press of the State. But he may have all the officers in the State, all the presses, and goods boxes of bonds, yet the people will rise up at the ballot-box and put them down. The people do know their rights, and knowing dare maintain them.

"A Voice: How about registration?

"The Speaker: There is a law on our statute books which requires a certain oath to be taken before an elector is qualified. Those who are not disfranchised have the right to vote on subscribing to that oath, and there seems to be no division as to the practicability of taking it."

There is no doubt but that this speech was instigated by the Democrats to furnish an incentive for my assassination. It placed my life in great peril, as a vacancy in the gubernatorial office would have resulted in the accession of Lieut.-Gov. James M. Johnson to the executive chair, and that would have given the Democrats immediate control of the State Government.

In this speech Johnson showed how thoroughly his mind was turned by Democratic blarney and promises of 
aid in the accomplishment of his future purposes. It caused general alarm among the Republicans of the State, lest by the contingency of my death, or by the accomplishment of other devices, he might get possession of the executive chair. This feeling of alarm was justified by a later attempt to get possession of the gubernatorial office by bogus impeachment proceedings. In this speech he indorsed the course of Governors Senter, of Tennessee, and Walker, of Virginia, in their base betrayal of the Republican party in those States.

On April 25, I $\$ 96$, I received a letter from the Arkansas Auditor of State, C. B. Mills, dated the previous day, announcing alleged irregularities in the funding of the State Debt by me some twenty-five years before. To this letter I immediately replied, acknowledging its receipt and asking for additional information, which was given in his letter of May I, upon the receipt of which I immediately instituted a thorough investigation.

The matter at first caused me some anxiety; not because I felt the least shadow of doubt as to the legality of all my transactions in the premises, but because of the very large defalcations of Treasurer Churchill and Auditor Crawford, which were brought to light in the year ISSI. I feared that in order to furnish vouchers for their false accounts they might in some way have used the bonds of the State that were left over in the funding process. I therefore brought Auditor Mills' letter to the attention of the former officers,-Treasurer Page, Auditor Berry, and Governor Hadley,-and requested such information on the subject as they might be able to give.

In the course of my investigations I took under consideration my message to the Legislature, delivered January 4, I $87 \mathrm{I}$, giving an account of my stewardship in the funding transactions, as follows $:^{17}$ 
"In order to carry out the provisions of an act entitled 'An Act to Provide for the Funding of the Public Debt of the State' I designated the American Exchange National Bank of the city of New York as the fiscal agency of the State, and placed in its possession, with proper instructions, 3,000 bonds of the State, properly sealed and attested, the same being registered in the office of the Auditor. Of this number the fiscal agent has exchanged for old bonds and accrued interest, twentysix hundred and twelve new bonds, leaving in his possession to be exchanged, from time to time, as application is made, three hundred and eighty-eight bonds. I recommend that a committee of the Legislature be raised to verify the exchanges already made, and if they be found to be correct, to destroy the old bonds . ..."

After examining this message I wrote to the American Exchange National Bank of New York City, under date of May I8, I896, and requested such information as they possessed upon the subject, to which the bank replied by telegram on May 27 as follows:

\section{"NEw YORK, May 27, I 896.}

"Powell Clayton, Eureka Springs, Ark.

"We hold receipts signed Henry Page, State Treasurer, and the Union Trust Company of New York, dated December seventy and September seventy-one, for three hundred seventeen thousand bonds deliverd in accordance with your instructions.

\section{"American Exchange National Bank."}

This telegram was confirmed by the following letter:

"Powell Clayton, Esq.,

$$
\text { "New York, May 27, I } 896 .
$$

"Eureka Springs,

"Arkansas.

"DeAR SIR: After considerable hunting, we have discovered and, in response to your letter of the 18 th 
inst., state that we hold receipts signed 'Henry Page, State Treasurer, and the Union Trust Company of New York,' for \$3 I 7,00o bonds.

"The numbers are as follows:

"From 64I to 890 inclusive.

$$
\text { " } 2049 \text { to } 993 \text { to } 2050
$$

"All these transactions must have been advised to you at the time, and there must be in the possession of the State full particulars in regard to the entire matter, and it would seem to us that it would have caused you much less trouble to have hunted this up at your end than to have sought the information at our end. Nevertheless, we have done the best we could in the matter at the moment, and trust the information will be what you need.

$$
\begin{aligned}
& \text { "Yours respectfully, } \\
& \text { "(Signed) D. Crark, } \\
& \text { "President." }
\end{aligned}
$$

I was about to communicate this information to Auditor Mills for his benefit when my attention was called to the following interview given by him to the Little Rock Democrat, May 27, I 896 :

"FRAUDULENT BONDS. STATE AUDITOR MILLS DISCOVERS A MARE'S NEST IN ARKANSAS FINANCE. BOGUS OBLIGATIONS OF '69. TWO HUNDRED AND FORTY BONDS WERE ISSUED WITHOUT AUTHORITY DURING CLAYTON'S TENURE OF OFFICE. SOME ONE IS RESPONSIBLE. OUR BONDED INDEBTEDNESS APPEARS TO BE THREE QUARTERS OF A MILLION LESS THAN HAS BEEN SUPPOSED.

"State Auditor C. B. Mills has discovered a mare's nest, and if everything works out properly it will re- 
sult in the incubation of some stern facts which will practically sweep away the greater part of the bonded indebtedness of the State. Should the allegations be made plausible after a thorough investigation of certain old bond transactions dating back to reconstruction times, and should the State win in the swamp land controversy now pending in Congress, the bonded indebtedness now hanging over the State will be reduced to a minimum, which will no longer be burdensome, and will be discharged with comparative ease. In the statement of the case, as presented by Auditor Mills, charges are made which it is quite possible will have a thorough airing in our courts. The first intimation that such a state of affairs exists was from the following advertisement, which appeared in the current issue of the Commercial and Financial Chronicle, of New York:

\section{" 'STATE OF ARKANSAS-BONDS OF I 869}

" 'The holders of Arkansas 6 per cent bonds of the I 869 series, Nos. 642,707 to 722,746 to 773,787 to 795,875 to 877 , and 883 to 890 (sixty-five bonds) may learn something of interest to them by addressing

$$
\begin{gathered}
\text { "Auditor of State, } \\
\text { "'Little Rock, Ark.' }
\end{gathered}
$$

"A Democrat reporter called on Auditor Mills and asked for an explanation. Following is his reply:

"'The bonds referred to in that advertisement were illegally issued while Powell Clayton was Governor, under act of April 6, I 869, but not in compliance with the act. There were 192 bonds of a batch of 500 , registered August 19, 1869, for which the State received no consideration; ninety-eight of them were returned and cancelled without cost to the State except one-half year's interest on forty-six of them; thirty of them have been 
redeemed by the State at a cost of $\$ 49,740$, and sixtyfive are still outstanding, and have been estimated as the undisputed indebtedness of the State, and were in the last report recorded at $\$$ I 58,000 .

"There were not in existence at the time State and Real Estate bank bonds sufficient to authorize the issuance of as many bonds under that act as were issued. While the authorities disregarded the spirit and evident intent of the law, they were doubtless originally issued under a misapprehension of the amount of outstanding State and Real Estate bank bonds, or the amount to be funded.

" At the date of the passage of the act 1773 of the 3030 Real Estate and State bank bonds were in the State and United States Treasury, and not subject to be funded, aggregating \$3,90I,4IO. They began to be cancelled and turned into the State Treasury as early as I 849: I 48 bonds were properly funded for 3 I IO bonds issued under the 1869 act. Henry Page, as treasurer, received $\$ 140,456$ of the Real Estate and State bank bonds and coupons on his sinking fund account, and other treasurers since that have received twenty-seven more, amounting to $\$ 8 \mathrm{I}, 5 \mathrm{I} 3 . \mathrm{I} 5$, and at least eight are still outstanding. I think there will be no trouble to show to any court of competent jurisdiction that there was no basis for 240 of the bonds issued under that act. The fact that 145 of them were returned and cancelled is evidence that they at least were wrongfully issued. They were not all returned at one time. Ninety-five were returned in 1875 , and fifty in November, I 879 . Of the thirty redeemed fifteen were paid in on Real Estate bank lands, eight were exchanged for certificates of indebtedness, and seven for Loughborough bonds with the State board of common school commissioners.

" 'I reported I 43 State and Real Estate bank bonds outstanding October, I 894 , besides the bonds held by the United States government. I was governed by the face of the original record in the treasurer's office, as I pre- 
sume my predecessors since reconstruction have been, and these reports of so large a number of these old bonds outstanding led to the investigation I have made.

"When Henry Page was treasurer he reported by numbers the outstanding Real Estate and State bank bonds, and included at least sixty bonds that were then, and had been for several years prior, and are now in the treasury vaults, while further investigation shows seventythree more of them have been refunded and redeemed, which appear upon the register as outstanding since i 872 . " 'This will make a difference of $\$ 547,970$ from my report and applies to all previous reports since 1872 , except as to accruing interest.

" 'Our legal bonded indebtedness was $\$ 705,960$ less than reported in I 894. I think that Messrs. Clayton and Page are, or ought to be, liable to the State for the $\$ 49,740$ the State paid to redeem the thirty-five bonds illegally issued.

" For some time I have been prosecuting the investigation, and I have come to the conclusion that there is something crooked somewhere, and even if the party responsible for it cannot be discovered and held liable for such fraudulent issuance of obligations from which the State derived not one cent of benefit, the fact should be established and the people at least relieved from the burden of an unjust and wholly unauthorized debt. I have been in communication with Gen. Powell Clayton on the subject, but the correspondence has not yet been productive of results. I have been urging upon the State debt board the necessity of instituting proceedings which will bring about the needed relief. Through the advertisement in the Chronicle I have located several of the outstanding bonds in the hands of New York capitalists and in other places, but the replies are uniformly indefinite as to number and specific nature. As soon as this may be definitely determined, I shall advise the institution of a suit to enjoin the treasurer from the payment of any more of the bogus bonds.'" 
This interview, so full of false statements and unjust reflections upon my integrity in connection with the business referred to, I brought to the attention of Auditor Mills in my letter of June 8, I 896, as follows:

"My attention has been called to a purported interview of yours published in the Arkansas Democrat of May 27, I 896 , relating to alleged irregularities in the issuance of certain Arkansas funding bonds. Although over twenty-five years have elapsed since the funding transactions occurred, your letter of April 24, I 896, conveyed to me the first intimation of any such alleged irregularities. At the close of said letter the following language is used:

"As this matter may be of interest to you individually, I think it proper that you be made aware of the fact before publicity be given; so that if you have any means of accounting for this apparent discrepancy it may be done. I have no desire to wrong you or any one connected with this transaction.'

"Although I did not ask or desire that any act of mine while Governor should be for a single moment concealed from the public, I think from the fair and manly expressions just quoted I was warranted in expecting, pending the conveyance by me of the information your letter seemed to invite, that you would confine your published expressions to established facts, so far as they reflected upon my action in the premises. After the receipt of your letter referred to I wrote you at two different times for more explicit information upon which to base my inquiry, to both of which you replied. Upon the receipt of your last letter (May 9, I 896) I proceeded to make inquiry in various directions and to hunt up and examine old documents that had slumbered peacefully for over a quarter of a century. On the 19 th of May I wrote you reporting progress, as follows:

" "Replying to your letter of May 9, I 896, although a lapse of twenty-five years had dimmed my recollection 
of the funding transaction under my administration, from access to papers and documents, and from information from individuals connected therewith, the matter now begins to come back to me, and I think I shall be able in a short time to fix the responsibility of official irregularities, if such exist, where they belong. I know that no such responsibility rests upon me, nor do I think upon any official under my administration. I am awaiting some information from Utah, New Mexico, New York, and other places. When received, I will communicate with you upon the subject.'

"Certainly there was nothing in this letter to cause you to believe that the correspondence you had invited had closed between us, but upon the contrary, it indicated that I had nearly reached the time when I could 'fix the responsibility of official irregularities, if such existed, where they belong.' This as I supposed was the information you desired. A short time after the receipt of this letter, for reasons of your own, you gave a public statement to the press in which you sent broadcast many statements which I believe the facts when made known will not justify. Since your reported interview came into my hands I waited to see if you would disavow its authenticity, but as you have not done so, I conclude it correctly reports your language.

"Lest you should have misunderstood my letter of May I8, I896, as practically closing the correspondence between us, I write this to inform you that I shall in due time communicate to you and the public all the information I shall then possess concerning the issuance of the bonds in question.

"In view of the injustice I believe your interview has done me, I trust you will not consider my action in giving this letter to the press inappropriate. My only object in so doing is that the public may know that I shall in due time give my version of the transactions in question." 
I received no answer to this letter and as I felt absolutely secure in the integrity and lawfulness of my position, and was unaffected in the least by Auditor Mills' oft-repeated threats of subjecting me to a suit, I concluded to let him wriggle out of his perplexities without help from me. The next heard from Auditor Mills on the subject is a Gazette interview of his, as follows:

\section{"AUGUST 2, I 896, BIG REDUCTION}

"AUDITOR MILLS BACK FROM HIS DEBT-CLEARING TRIP "SHAVING OF THE STATE'S OUTSTANDING INDEBTEDNESS IS THE RESULT

"OLD BONDS ACCOUNTED FOR

"State Auditor C. B. Mills returned yesterday morning from New York, having carried out his mission of investigating the whereabouts of alleged illegal bonds carried on the books as part of the State's outstanding indebtedness. Auditor Mills says he went to New York assured that he would find seventy of these bonds. $\mathrm{He}$ found 64 of the ' 65 issue, and twenty-five good bonds of the ' 69 series, also six Holford bonds and a large amount of coupons. All except four of them had been deposited with the Union Trust Company by ex-Treasurer Henry Page in 1874 , subject to the order of the treasurer of Arkansas. These bonds were all on deposit there when Governor Eagle and the State board had turned over to them in I89 I the ninety bonds funded by the United States Government. It was ascertained that the bonds were deposited by an attorney for Page. They have appeared from time to time in the official statements of the State's outstanding indebtedness. The State has paid out thirty of the alleged illegal bonds and will get back twenty-five valid bonds, and thus in the end the State will be out only about $\$ I 0,000$, the amount of five bonds paid. There will be a difference of $\$ 200,000$ in the debt statement of Arkansas. The ferreting out of the 
invalid bonds makes a reduction in excess of that amount on the outstanding indebtedness.

"Auditor Mills says that his investigations have failed to disclose that ex-Governor Powell Clayton was in anywise connected with the issuance of the bonds referred to." 18

I had long since learned that so far as I was concerned the amende honorable was not to be expected from any Democratic source. This admission, I suppose, was about as near as Auditor Mills dared to go. His predicament was fully exposed by the following memorandum of the Union Trust Company, of New York, in answer to a letter from Eugene Lankford, Chairman of the Joint Committee of the two Houses of the Legislature, appointed to investigate the funding bonds:

"February I9, I901.

"The Bonds of the State of Arkansas came into the possession of this Company as the financial agent of the State.

"This Trust Company conducted the exchange of bonds until July 13 , I 896 , when at the written request of Governor Clark all bonds, books, coupons, etc., were delivered to Mr. Ransom Gully, State Treasurer, whose receipt we hold.

"We were asked if the banking books show any of the transactions relating to the bonds of the State and answer that the books show all exchanges, but as they are in the possession of the State Officers we must refer you to them.

"Answering the question if Mr. W. P. Denkla had any connection with the exchange of bonds, our reply was that our recollection is that some of the bonds were exchanged by W. P. Denkla, and if so, the books will show it.

"In reply to the question, Why old bonds and bonds 
for which they were exchanged were both in the possession of the Union Trust Company? They were placed in our possession in order to enable us to make the exchange. This is also shown in the books of the State authorities.

"Replying to the question, If this company acted as Exchange Agent for the State Funding Bonds, what duties it had to perform? It received the old bonds and delivered the new bonds.

"We delivered all papers, books, etc., in regard to this transaction and are therefore unable to more fully describe the various transactions, but they are fully described in the books which we surrendered, and we feel sure if you will consult the funding book you will find all the information you desire."

Thus Auditor Mills, after all his trouble, was forced to take a back seat, where he is likely to remain for the rest of his life. His charges were forever set at rest much to the disappointment of the Democrats, for they had long endeavored to fix some official rascality upon me and had hailed this opportunity with delight.

It will certainly be evident to all fair-minded people that before Auditor Mills rushed into print with his false and malicious charges and threats to bring suit against me he should have exhausted every effort to ascertain the facts upon which he based such action. He should at least have examined carefully all official documents relating to the transaction. The message of a former Governor, charged with the funding of the debt, certainly should have been considered an official document of the highest order, and should have received his first attention. If he had done that, he would not only have saved himself from subsequent retraction, but would have saved his party from the damaging disclosure that during fifteen years of administration it never had been 
able to state within three-quarters of a million dollars the amount of the State's indebtedness.

Without inquiring into the correctness of the figures upon which this newspaper account was based, ${ }^{19}$ it shows the incompetency of the Democratic party to keep the accounts of the State. It is a remarkable acknowledgment that the State debt was nearly three-quarters of a million less than had for so many years been reported by the Democracy and charged to the Republicans as a debt of their making.

\section{FOOTNOTES FOR CHAPTER XII}

${ }^{1}$ Arkansas House Journal Appendix, I856, p. 375.

${ }^{2}$ Arkansas House Journal Appendix, 1856, p. 376.

${ }^{3}$ Arkansas House Journal Appendix, 1856, p. 376.

${ }^{4}$ Arkansas House Journal Appendix, 1856, p. 377.

${ }^{5}$ Arkansas House Journal Appendix, 1856, p. 379.

${ }^{6}$ Arkansas House Journal Appendix, 1856, p. 377.

${ }^{7}$ Arkansas House Journal Appendix, 1856, p. 383.

${ }^{8}$ Arkansas House Journal Appendix, 1856, p. 387.

${ }^{9}$ Report of the accountants appointed under the Act of January 15, 1855, to investigate the affairs of the Real Estate Bank of Arkansas, p. 25.

${ }^{10}$ Arkansas Senate Journal Appendix, I856, p. 39 I.

${ }^{11}$ Arkansas Laws, I843, pp. 77-87.

${ }_{12}$ Arkansas Senate Journal Appendix, I856, p. 391.

${ }_{13}$ Arkansas House Journal, 1868-1869, p. 22.

${ }^{14}$ Arkansas Laws, I 868-1869, pp. I I 5-1 I 8.

${ }^{15}$ Constitution of the State of Arkansas, 1868, Article 6, Section Io.

${ }^{16}$ See pp. 259-26o.

${ }^{17}$ Arkansas House Journal, I871, p. 26.

${ }^{18}$ Italics are mine. P. C.

${ }^{19}$ See pp. 272-275. 


\section{CHAPTER XIII}

WILLIAM M. FISHBACK, OR DEMOCRATIC PERVERSIONS OF HISTORY

A description of the different rôles in which William M. Fishback appeared on the political stage of Arkansas is perhaps timely.

In I 857 he went from Virginia to Illinois, where he remained only one year. He then went to Sebastian County, Ark., and located at Greenwood, where he was so pronounced in his Union sentiments as to cause the Unionists of that County to send him as their delegate to the Secession Convention, which assembled at Little Rock, March 4, I 86I, to determine the attitude of the State in the impending crisis, - that is, whether it should remain in the Union or join the Southern Confederacy.

In that Convention, on the test vote for the presiding officer, the Unionists developed a majority of ten, and Mr. Fishback was among that number. However, when the Convention re-assembled on the 6th day of May, I $86 \mathrm{I}$, but one man voted in the negative ${ }^{1}$ upon the adoption of the ordinance of Secession. His name was not W. M. Fishback, but Isaac Murphy,-the grand old patriot. Mr. Fishback voted with the Secessionists throughout the entire proceedings of the Convention.

When the war actually began he went back to Illinois. Early in 1863 he returned to Arkansas. Notwithstanding the fact that he had never had any military experience, his first effort was to raise an Arkansas Union 
Regiment, of which he was to be the colonel. Failing in this, not long afterward he. engaged in a second effort to raise a regiment, which was first known as the $3 \mathrm{~d}$ Arkansas Infantry, then as the 4th Arkansas Infantry, and finally as the 4th Arkansas Cavalry. ${ }^{2}$ These efforts failed.

In I 864 the Union men of Arkansas established the provisional "Murphy Government," 3 and he (being unable to differentiate between such a government, the sole creature of the military, and the government of a coordinate State of the Union) at once aspired to the highest position that he supposed was in its power to give,a seat in the Senate of the United States.

Apparently in order to obtain favor with the Union men that predominated in the Legislature, he delivered before that body a red-hot speech, denouncing the atrocities of the Confederate Government in Arkansas in the execution of its Conscription Act, and in its treatment of Union men generally. As editor of the Unconditional Union, a newspaper established by him and Judge Yonley about that time, he used its columns for similar utterances. From this paper,-February I9, I864,-I quote as follows:

"EXTRACT FROM MR. FISHBACK'S EDITORIAL, 'RALLY AROUND THE FLAG, BOYS'

"For three years a devastating and consuming civil war has raged in our State which, like the Simoon, has withered and blighted all that fell in its way. For three years the loyal men of this State have had no certain tenure of life or property; no home or abiding place, but mere aliens in the land of their birth, cast out and proscribed by a wicked, unpitying, and unrelenting rebel tyranny; a tyranny which delighted in blood, hungered 
and thirsted after the lives of the loyal people, and, in the consummation of its inhuman purposes and desires, arrived at a perfection in the art of torture and brutality that the thongs of India, though guided by the inspiration of the heathen goddess of murder, have failed to attain.

"The Union men of Arkansas have been hunted through wilds and mountains with bloodhounds, urged forward by the minions of the Davis oligarchy, who were not less cruel and bloodthirsty than the irresponsible animals whose actions they controlled. And when the victim of the chase was overtaken he was forced into the rebel service or hanged upon the nearest tree, as the whim or caprice of his captors determined; and, being hung, his body was denied the rights of sepulchre and left suspended between heaven and earth, there to become food for the beasts of the forest and fowls of the air. And all this, too, because he was a Union man, and for no other reason."

The result of the so-called Senatorial election was that Mr. Fishback and Elisha Baxter went to Washington with credentials from the "Murphy Government" upon which they expected to obtain seats in the United States Senate. In vain they knocked at the doors for admittance, and at length, disappointed and crestfallen, they returned to Arkansas.

In the winter of I 865 the publication of the Unconditional Union ended because of lack of patronage. Mr. Fishback previously had obtained a temporary appointment at six dollars a day as Assistant Special Agent of the Treasury Department, ${ }^{4}$ his duties being to take charge of confiscated and abandoned rebel property in Arkansas.

After the close of the war Mr. Fishback awaited the trend of events. Because of his uncertain attitude, the Republicans did not select him as a delegate to the first 
Republican State Convention, which assembled at Little Rock, April 2, I867. This caused him, later on, to turn a complete somersault, landing in the bosom of the Democratic party, which was composed of the same character of men as those he had so viciously assailed in his newspaper article reproduced on pages $283-284$, and thenceforward he was found among them, out-Heroding Herod.

In 1872 he was selected by that party to represent Sebastian County in the Legislature; in I 874 he was a member of the State Constitutional Convention, controlled by the Democratic party, which had just come into power; in I 876,1878 , and I 884 he was again the Democratic representative from Sebastian County in the Legislature, and in 1892 he became, for one term, the Democratic Governor of the State.

This completes Mr. Fishback's history until he appeared upon the political stage as the champion of Democratic repudiation of the State's financial obligations. ${ }^{5}$

\section{MR. FISHBACK ON RECONSTRUCTION IN ARKANSAS}

In I $890 \mathrm{Mr}$. Fishback, conjointly with thirteen other Southern Democratic politicians, published and circulated far and wide, especially in the Northern States, a "copyrighted" book, entitled "Why the Solid South, or Reconstruction and Its Results," ${ }^{\circ}$ to which he contributed Chapter XI- "A Vivid Picture of the Carpet-bag Era in Arkansas."

His preliminary remarks are disingenuous throughout. In view of the facts that I have thus far and I shall hereafter establish, they are so misleading as to cause me to reproduce them, as follows: ${ }^{7}$

"Crimination and recrimination are as repugnant to good taste as they are to my own inclination. Between 
sections of a common country they are criminal. Under this conviction, and that all parts of our Republic might be fraternized and united in a combined effort to build up our great nationality, the Southern statesmen have abstained from replying to the many slanders against the Southern people which have been widely circulated by Republican leaders until their unanswered reiteration has led to the belief that they are true, and has produced such widespread and deep-rooted prejudices among their less informed followers as to amount, in the judgment of thinking and patriotic men, to a serious danger to our institutions.

"As evidenced by the character of the late Presidential campaign in the North, that section is becoming as separate and antagonistic as if we were two distinct and hostile empires.

"Surely this is to be deplored, and surely it becomes a public duty of Southern men who know the facts to disabuse the minds of the more candid of our fellowcitizens of the North; to let them see that the antagonism of the people of the South to the Republican party is in no sense an antagonism to the Northern section of our common country; to show them that the conduct of this party in the South was such as not only to repel the patriotism and decency of the South, but was also such as should serve as a monumental warning to the American people against all attempts to seek party advantage through illegitimate or doubtful legislative enactment.

"It is under this conviction of duty that I have consented to write this review of reconstruction in Arkansas.

"Nor is there the slightest admixture of malice in anything I shall say. Accordingly, I shall not mention names except when absolutely necessary. I write not of persons, but of conditions, and methods, and outrages, 
which I could have hoped it might never be necessary to recall.

"Indeed, many a man who participated in these outrages, when surrounded by the temptations thrown around him by the then conditions, has become a respected and law-abiding citizen since he has been surrounded by the better influences of Democratic supremacy. I shall respect his present standing, holding myself ready, however, to furnish names upon any demand entitled to respect."

The true sentiments of the party into which Mr. Fishback fell headlong, when he turned his political coat, are in my opinion more candidly expressed in the following article from the Gazette, September i 8, I 868 :

\section{"POLITICAL OSTRACISM}

"In the article under the above caption the Camden Journal complains bitterly at the social ostracism proposed by some of our Democratic contemporaries to be exercised toward radicals, and asks with apparent innocence, 'What has the Republican party done to merit this feeling?' This question would come with about as good grace from a highway-man when arraigned before the bar of justice after he had robbed a community of their property, despoiled their homes, outraged their women, beggared their children, and bound their men hand and foot while he perpetrated these hellish deeds. The question should rather be asked, 'What is it the Radical party has not done to make every decent Southern man hate, loathe, and abhor every single member of that party?' Possessed of power, with Federal bayonets at their command to enforce every infamous scheme that malice could dictate or avarice suggest, they have perpetrated deeds of wrong, oppression, and insult against the downtrodden 
and helpless people of the South that would put to shame the most savage band of Comanche Indians that ever roamed the western plains. What have they done? Go to the squalid homes of those who once revelled in every luxury that heart could wish and hear their children beg for bread, and ask them who has done this? The sorrow-stricken mother, with tear-bedewed cheek and voice stifled by heartbroken sobs, will tell you, 'The Radica! party.' Go to the once busy marts of trade and see the merchants, mechanics, and artisans lounging about their doors waiting for trade and work, and ask them what has caused this great change in the business aspect of their city, and they will tell you, 'The Radical party.' Go to the farmer, and ask him why his once blooming fields are lying in waste and uncultivated, and he will tell you, 'Because of the ruinous policy of the Radical party.' Go to your treasuries, state and national, look into their empty vaults, and ask their keepers what has become of the gold which once lined them, and if they would tell you truly, they would say, 'Squandered by the Radical party.' Ask the head of the treasury department who created this mountain of debt under which the government now groans, and he will tell you, 'The Radical party.' Go to the polls, see the illiterate and ignorant negroes jostling away our most worthy and intelligent white men, and ask who has done this, and the answer will be, 'The Radical party.' Go to that group of citizens standing on the corner of the street, with anxious countenances and 'whispering with white lips' of an anticipated riot with the negroes, and ask them why such fear, and they will tell you, 'The damnable teachings of the Radical party.' All these wrongs, aye! a thousand times more, have that party heaped upon the South, and yet they have the unblushing effrontery to ask us to treat them as friends and associates. As well take into our 
bosom the poisonous adder or into our houses a rabid dog as to cultivate terms of sociality and friendship with these vampires upon the body politic,- - these despoilers of the rights and liberties of our people. It is too much to ask the Southern people to exercise the Godlike attribute of forgiveness toward a set of men who have perpetrated every wrong against them that cupidity or malice could invent."

The allegations of Mr. Fishback throughout his entire article are vague, mendacious, and unsupported. I believe the reproduction of three of his statements will be sufficient to prove this assertion. On pages 3 I6-3I 7 of his chapter he uses the following language:

"When I introduced to the Constitutional Convention of 1874 the resolution looking to repudiating the fraudulent bonds above described, a banker from New York or Boston, I forget which, was at Hot Springs, and remarked to a distinguished citizen of the State: 'I have some of those bonds myself.' The gentleman asked him if he did not know how fraudulent they were, and that the people would not pay them. He replied: 'I don't think they ought to, but they only cost me fifteen cents on the dollar, and I believed the Republicans would hold this State for the next twenty-five years, and in that time I would get a dollar for my fifteen cents.'"

Mr. Fishback does not state the banker's name, has forgotten his place of business, fails to mention the name of the distinguished gentleman to whom he was talking, has not specified the character of the bonds, whether Railroad or Holford; and, last but not least, he does not say that the language attributed to the banker was spoken in his presence, and if not, from what source his information was obtained. 
Even if this statement were accepted without criticism, what bearing would it have upon the question of why the South is solid, or what color would it give to his vivid picture?

On pages $297-299$ of his article he refers to the operations of Martial Law, as follows:

"Although Gen. C. H. Smith, U. S. A., commanding the district of Arkansas, wrote to his superior officer that there was no state of facts existing in Arkansas to warrant such a step, the Governor upon the flimsiest pretexts declared martial law in a number of counties where the people were most outspoken in their denunciations of the government which had been thus foisted upon them without their consent. Negro militia marched and marauded and murdered at will through these counties.

"I might fill page after page with their atrocities, but I forbear lest their detail stir up animosities which could do no good but were better suppressed.

"They grew, however, to such enormity as to shock especially the 'old citizens,' who were members of the Legislature, and who were not fully into the secrets of the conspiracy between Congress and their carpet-bag representatives, as will be seen by the following general order:

“'Little Rock, December 4, is68.

" 'Brigadier-General Upham, " "Commanding Dist. N. E. Ark.

" 'General: I am instructed by the Governor to write you as follows:

" Although the Legislature in the first part of the session fully indorsed the action of his excellency in declaring martial law, and putting into active service the State Guards, it is apparent now that many of them are 
"weakening"; especially are the old citizens beginning to refuse that support which should be given the executive at this time. In order to prevent the growth of this feeling and to take advantage of this faction it is desirable that our military operations be pushed to an end within the next thirty days. All we can do now is to show the rebels that we can march the militia through any county in the State whenever it is necessary. Use every effort to catch the desperadoes in Woodruff, Craighead, and Greene counties.

"I hope you will end your operations in your section as soon as possible. You see we are likely not only to have to fight the rebels but the Legislature also. We don't propose to allow any advantage. I am, General, your obedient servant,

"'Keyes Danforth, Adjutant-General.'

"In another order to Gen. S. W. Mallory, commanding Southeast District of Arkansas, on the $25^{\text {th }}$ day of December, I 868, the following sentence occurs, 'He,' the Governor, 'thinks you may safely execute many of them; it is absolutely necessary that some examples be made. " 'Private Secretary.'

"It will be seen that he dare not sign his name to this carte blanche commission to murder."

I neither dictated nor approved any such letters, and even if they were written and transmitted by AdjutantGeneral Danforth or my private secretary Barton, I do not hold myself responsible for indiscreet and unofficial expressions of subordinates. Any official correspondence over my own signature would be quite a different thing.

It is a fact that at first General Smith was not in favor of my martial law policy. He had a plan of his 
own, which was to station detachments of the United States troops at the county seats of the various counties where the conditions were most disturbed. The following extract from the report ${ }^{s}$ of General Porter to General Grant shows that at a later period General Smith completely changed his views:

"The entire Conservative wing of the Republican party was opposed to the declaration of martial law, including General Smith, United States Army, commanding the troops. They admitted the reign of terror established by the rebels, but wanted the United States troops to make the arrests. . . . It has, however, accomplished much more than the most sanguine expected, and General Smith acknowledges that the Governor's policy was better than his, and that the result would fully justify the action of the former."

I recall to the reader that the subject of martial law and its beneficial results have been already discussed in Chapter VI and Chapter VIII.

To show Mr. Fishback's ignorance of the State Aid Law and his reckless misrepresentations, I shall briefly discuss his assertions on pages 309-3 Io of his article, headed "Fraudulent State Bonds," which are as follows:

"Under a law since declared unconstitutional by our Supreme Court, bonds of the State were issued during Reconstruction to the amount of $\$ 5,350,000$ to certain railroad companies, all in fraud of the law, even if it had been constitutional. From two to three times as much was issued to each road as the terms of the law allowed.

"To the Memphis and Little Rock Railroad Company was issued $\$ \mathrm{I}, 200,000$, nearly three times as much as was allowed by the terms of the law. 
"To the Little Rock, Pine Bluff, and New Orleans Railroad Company were issued:

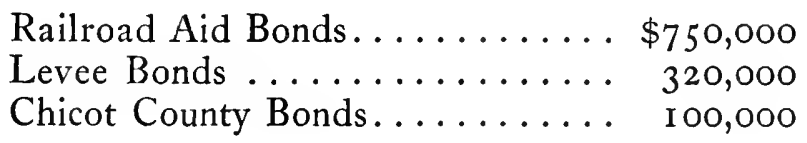

This company built for all this only tweive miles of road, and then took up the iron to put it on other roads to draw bonds anew.

"To the Mississippi, Ouachita, and Red River Railroad Company .... were issued both railroad aid bonds and levee bonds and Chicot County Bonds,-all fraudulent. . . . And every road that received them was so much crippled that its completion was delayed for years. The State not only did not receive any benefit but injury instead."

With the exception of the total amount of bonds issued, mentioned by Mr. Fishback in the first paragraph, all these allegations are absolutely incorrect. As I issued and delivered the majority of the bonds in question, I shall depart from what is really required of me in order to show how unjustified are the assertions crowded into these four brief paragraphs.

Not a single one of the bonds issued by me was in fraud of the law, but in strict conformity therewith; the receipts and other documentary evidences of which are in my possession and can, or should, be found where they were originally filed, in the proper Department of State.

In the first and second paragraphs of his article $\mathrm{Mr}$. Fishback clearly contradicts himself by stating that all the bonds issued by the State were in fraud of the law,therefore, illegally issued. Then he proceeds to say that 
the amount issued to each road, and to the Memphis and Little Rock road in particular, was from two to three times as much as the terms of the law allowed. This is an admission by Mr. Fishback that the law did provide for at least a part of the bonds issued to the various railroads.

In paragraph three $\mathrm{Mr}$. Fishback states that to the Little Rock, Pine Bluff, and New Orleans Railroad Company was issued $\$ 75^{\circ}, 000$ in bonds. If he meant that this amount was issued by me, he is correct. However, when he said that for this amount only twelve miles of road were built he was either grossly ignorant of the facts or he misrepresented them. About seventeen years before his comments were published trains were running regularly from Chicot to Pine Bluff, a distance of seventy miles.

This is substantiated by the fact that when this road and the Mississippi, Ouachita, and Red River Railroad were consolidated in the fall of 1873 , in order to comply with the provisions of the law as to certain preliminary proceedings, the stockholders and directors took a special train to the eastern terminus on the Mississippi River, where the domicile of the company was then maintained, and where we found the yellow fever raging so severely that we held a hasty meeting in one of the cars and returned to Pine Bluff that day by the same train.

This allegation is further supported by the following extract from a letter from Mr. B. F. Bush, ${ }^{9}$ President of the Missouri, Pacific Railroad Company, of which the Little Rock, Pine Bluff, and New Orleans is now a part. He says:

"At the time the Little Rock, Pine Bluff, and New Orleans Railroad and the Mississippi, Ouachita, and Red River Railroad were consolidated in the year I873, under 
the name of the Little Rock, Mississippi River, and Texas Railroad Company, the former was constructed and in operation from Chicot to Pine Bluff, a distance of seventy miles. ..."

Surely these statements will not be questioned by any honest man conversant with the facts.

Now I come to his charge that the company "then took up the iron to put it on other roads to draw bonds anew." It must be evident to any intelligent person that a company would not go to the expense and trouble of laying rails on one road to obtain bonds, and afterward to the additional trouble and expense of taking up and re-laying them upon another road to obtain a new issue of bonds when the law does not contain a single word that can be construed as requiring the railroad companies to lay rails as a prerequisite for the receipt of bonds, but, on the contrary, it clearly shows that after the bonds are earned by the grading, bridging, and tying of ten consecutive miles of road, and are thereupon issued, "The bonds, or the avails thereof, shall be used for the sole purpose of providing for the ironing, equipping, completing, or building of the said road." 10

When the "Swamp Democracy" saw the rails being taken up and shipped to another road and re-laid, they started this foolish yarn, which was taken up by the $G a$ zette, July 29, I87I, under the title of "The Grand Swindle," from which I quote as follows:

"Imagine our surprise, therefore, when on the 17 th instant the locomotive with a train of cars and a number of laborers arrived at the end of the track, and the work of taking up the iron was commenced,- - the iron for which they have succeeded (I will not say with the connivance of the State authorities) in drawing from 
the public treasury of the State the sum of $\$ 750,000$. Upon inquiry we were informed that the iron was to be taken up and laid on the Mississippi, Ouachita, and Red River Railroad,-possibly to draw another \$750,ooo from the plethoric and overflowing coffers of the State."

The facts in the case were that the Little Rock, Pine Bluff, and New Orleans Railroad Company's line from Pine Bluff to the Mississippi River ran all the way through the bottom lands of the Arkansas and Mississippi Rivers, and the almost imperceptible grade admitted of light motive power; hence lighter rails were used than were required on the Mississippi, Ouachita, and Red River Railroad, where in places the grades were considerable. The two roads had in New Orleans a joint agent, who had purchased and erroneously consigned the rails in question to the Little Rock, Pine Bluff, and New Orleans Railroad, upon which they were laid. It was only to correct this error that the rails were taken up and delivered to the company to which they belonged, and the proper rails substituted.

That story was used for all it was worth, and its circulation was persisted in for years after its thorough and complete refutation. And Mr. Fishback, the historian (?), rehashed it, when any investigation of the law would have disclosed its untruthfulness.

That the reader may understand the falsity of his charge in paragraph four,- - that certain levee bonds were "fraudulently" issued to the Mississippi, Ouachita, and Red River Railroad Company,-I quote from the law relating thereto, which fully authorized such action:

"Any railroad company that shall construct a roadbed through any portion of this State which shall answer 


\section{CIVIL WAR, IN ARKANSAS}

the purpose of a levee for the protection of any lands of the State from overflow, or shall cause the draining of the same by any continuous line of ditches, shall be entitled to receive an amount of the warrants of the Auditor, authorized to be issued by this act, equal in amount to the expense of protecting the same lands from overflow by levees or drains made by the State, which amount shall be determined by the Commissioner of public works and internal improvements. . . ."11

As to the Chicot County Bonds mentioned by him, they, like others of a similar character, were issued under the provisions of the following act:

"The Board of Supervisors of any county is authorized and empowered to issue bonds of such county in any sum necessary, not greater than ten per cent, inclusive of all other bonded indebtedness of the assessed value of the taxable property of said county, for the purpose of aiding in the construction of railroads, or other works of internal improvement." 12

Therefore this power was lawfully exercised by the county authorities.

His statement that "every road receiving State Aid was so crippled that its completion was delayed for years and that the State received only injury instead of benefit" is erroneous in each respect. On the contrary, it gave enormous impetus to the construction of railroads, resulting in the building by State Aid alone of 445 miles of road in five years, while it took the Democrats, after they came into power, with all their resources, eight years to build as many miles. 
MR. FISHBACK'S CHARGE OF "CARPET-BAGGERS" IN ARKANSAS

Mr. Fishback in the caption of his article characterized the Republican Rule in Arkansas as the "CarpetBag Era," and throughout his article in speaking of the Government and its officers he frequently used the expression "carpet-bag" and "carpet-bagger." From the Century Dictionary I quote the following definition of the word "carpet-bagger":

"An opprobrious term applying properly to the class of adventurers who took advantage of the disorganized condition of the political affairs in the early years of reconstruction to gain control of the public offices and to use their influence over the negro voters for their own selfish ends."

I believe that this applies more nearly to the Arkansas conditions than the definitions given by any other dictionary, and therefore I shall adopt it as the basis for my discussion of the question.

The names of the officers who composed the socalled "Carpet-Bag Government" were obtained from the report of the Secretary of State, Ark., 1907-8 $;^{13}$ and I procured additional reliable data concerning them by extensive correspondence with old citizens of the counties or localities where they served. I have been careful to exclude all information that I did not consider sufficiently definite, and the results are presented in the following general statements:

\section{EXECUTIVE STATE OFFICERS}

Governor.-Powell Clayton. When mustered out of the United States Army in 1865 he married one of Arkansas' daughters, - a young lady of Confederate par- 
entage,-and immediately thereafter purchased and settled on one of the largest plantations on the Arkansas River, having,-with his brother W. H. H. Clayton (who invested $\$ 5,000$ in the venture), - paid therefor over $\$ 53,000$ in cash. He continuously resided upon this plantation until ill treatment by his ex-Confederate neighbors became so pronounced as to cause him to take a political stand for the preservation of his life and property.

Lieutenant-Governor.-James M. Johnson was a native of Virginia, and he came from that State to Arkansas in 1836 . When elected to office he was a physician practising medicine in Madison County, Ark.

Secretary of State.-Robert J. T. White came to Arkansas from Virginia several years before the civil war.

Auditor of State.-James R. Berry was a native of Alabama, and he settled in Arkansas in the year $184 \mathrm{I}$.

Treasurer.-Henry Page was an officer in the Union Army. He came to Arkansas during the civil war. When he was mustered out he decided to remain, and as early as I 866 he was engaged in the culture of cotton.

Attorney-General.-John R. Montgomery was a Northern man, and he settled in Arkansas at the close of the civil war.

Commissioner of Immigration and State Lands.-Dr. James M. Lewis came to Arkansas from Massachusetts as an Army officer; when mustered out he settled at Little Rock, engaged in the practice of his profession, and in 1870 was reported as being engaged in the building of a fine residence in Little Rock for his own use. ${ }^{14}$

Superintendent of Public Instruction.-Thomas Smith was a Northern man; he settled in Arkansas at the close of the war. I have no other reliable information concerning his settlement in the State. 
CIRCUIT SUPERINTENDENTS OF PUBLIC INSTRUCTION

I remind the reader that in Chapter $\mathrm{X}$ it is abundantly shown that the native Arkansan was entirely deficient in the qualities necessary to organize and manage the school interests of the State; hence, in the selection of these officers I regarded efficiency and experience as outweighing all other considerations. The result was that a majority of them were Northern men, from such States as were renowned for the excellence of their public school systems.

Seven of the ten Circuit Superintendents were from the Northern States, but they had, however, settled in Arkansas prior to the enactment of the Reconstruction Measures. Of the other three, Major Chrisman had served throughout the war as an officer in the Confederate Army. E. E. Henderson's nativity I am unable to state, but he settled in Arkansas the last year of the war and engaged in the real estate business. Rev. W. H. Gillam was a native of Arkansas.

\section{THE JUDICIARY}

W. W. Wilshire, Chief Justice, a native of Illinois, came to Arkansas as an officer in the Federal Army, and at the close of the war settled in Little Rock, where in partnership with Judge English he engaged in the practice of law.

Associate Justice.-Thomas M. Bowen came from Iowa to Arkansas as the Colonel of a Federal regiment. During the last year of the war he retired from the service, married the daughter of a prominent Southern man of Van Buren, Ark., and engaged in agricultural pursuits. 
Associate Justice.-Lafayette Gregg was a native of Alabama and settled in Arkansas in 1835.

Associate Justice.-W. M. Harrison was a native of the State of Maryland; he came to Arkansas and located there in 1840 .

Associate Justice.-John McClure was a native of Ohio. In partnership with his brother-in-law, $\mathrm{Mr}$. Rice, then a Congressman from one of the Ohio Districts, he rented a large plantation on the Arkansas River in I 866, and engaged in the cultivation of cotton. Later he moved to Little Rock and purchased the home in which he has continued to reside until the present time.

Chancellor of Pulaski Chancery Court.-T. D. W. Yonley's nativity I do not know. However, he settled in Arkansas in 1859 and engaged in the practice of law.

Solicitor-General.-M. W. Benjamin was the Adjutant of my old regiment, the 5 th Kansas Cavalry. That regiment's term of service having expired before the close of the war, he was mustered out, then he located in Little Rock, and in partnership with his brother-inlaw, B. F. Rice, engaged in the practice of law.

The large brick building nearly opposite the State House, known as the Benjamin Block, was built by him. $\mathrm{He}$ also built and owned a very handsome residence in the western part of the city-a residence which he occupied until his death, and which was the home of his family thereafter.

Before the war he was a citizen of Iowa, but the State of his nativity I do not remember.

\section{JUDGES OF THE CIRCUIT COURT}

Of the ten Circuit Judges six were originally from the North, but all settled in Arkansas before or at the close of the civil war. E. D. Ham's nativity is unknown 
to me, but he settled in Arkansas before the civil war. The remaining three were natives of the South and all settled in Arkansas between the years I 850 and I 852 .

\section{PROSECUTING ATTORNEYS}

Four of the Prosecuting Attorneys were natives of the South, and one of them, Gen. E. W. Gantt, was at the close of the war a Brigadier-General in the Confederate Army. The other three either came to Arkansas prior to or during the civil war. The nativity and settlement in the State of N. J. Temple, J. R. Page, C. B. Fitzpatrick, and D. D. Leach I have been unable definitely to ascertain, but they all located in the State prior to the passage of the Reconstruction Measures of Congress. J. McL. Barton was a native of Maine, and he settled in Pine Bluff in 1867 . W. A. Inman was a native of Indiana. I am not able to give the date of his settlement in the State except that it was prior to the enactment of the Reconstruction Measures.

\section{THE SEVENTEENTH GENERAL ASSEMBLY}

The first General Assembly that convened after the passage of the Reconstruction Measures was composed of 104 members, -24 in the Senate and 80 in the House of Representatives. The Little Rock Gazette, of April 4, I 868, makes the following statement relative to the Senate: "One negro, a large number of Southern men, and a few Northern men compose the Senate."

For information relative to the House of Representatives, I give the following account from the Little Rock Republican, of July I6, I 868, the correctness of which has never been questioned: 


\section{"CARPET-BAGGER}

"In looking over the Roster of the Senate and House of Representatives, it occurred to us to apply a few figures to see how far the charge of 'Carpet-bagger' would be sustained thereby. A stranger in the country reading the Gazette alone would infer that the legislature was made up of a swarm of Yankees who had come down here crowding the 'decency,' respectability, and intelligence of the State to one side, took possession of the Government and were running the same without regard to the feelings of the aforesaid 'respectability,' 'decency,' etc. The roster before us contains the names of eighty members [the entire body] of the House of Representatives, with their nativity. Kentucky, 7; Ohio, 5; Missouri, 2; South Carolina, 2; New York, 3; Arkansas, 4; Tennessee, 20; Indiana, 6; Virginia, I; New Hampshire, I ; Georgia, 5; Pennsylvania, 4; Louisiana, I ; District of Columbia, I ; Illinois, 3; North Carolina, 3; Alabama, 3; Vermont, 2; Massachusetts, 2; Michigan, I ; England, I; Canada, I; Germany, I. Occupations,-Lawyers, 6; Physicians, 7 ; Editors, I; Farmers, 42 ; Merchants, 8 ; Ministers, 2 ; Saddlers, I ; Civil Engineers, I ; Machinists, I; Blacksmiths, I; Miscellaneous, Io.

"Members from the Southern States, 48; Members from the Northern States, 27; Members from District of Columbia, I; Members from foreign countries, 3 ; showing almost two-thirds of the House natives of the Southern States. The average residence in the State is twelve years. What now becomes of the Gazette's, and other pro-rebel luminaries', charge of 'carpet-bagger,' as applied to the members of the present Legislature! Rather venerable "carpet-baggers' it occurs to us." 


\section{THE EIGHTEENTH GENERAL ASSEMBLY}

In the Senate of the I 8 th Legislature, which convened January 2, I 87 I, there were twelve members who had held over, and, with the exception of two negro members instead of one, it was practically of the same political complexion as that given by the Gazette for the preceding Legislature.

The composition of the Lower House of the 18 th Legislature, with its addition of nineteen Democratic members, no one of whom Mr. Fishback would characterize as a "carpet-bagger," goes to prove my assertions.

\section{COUNTY OFFICERS}

I now present an abstract showing the nativity of the officers in the sixty counties of the State, based upon such correct information as I have been able to obtain. The names of all these officers can be found in the Report of the Secretary of State, Ark., 1907-8.15 They were elected for a term of four years, but in some instances they served only two years, and were replaced by officers who served the remainder of their terms, which accounts for there being a larger number of officers than there were counties.

\section{JUDGES}

Of the 64 county Judges, I 5 were natives of Arkansas; 9 came to the State in childhood, I 6 came prior to the civil war, 2 during the war, 6 immediately thereafter, and 2 in 1867 . As to the remaining I2, I have been unable to get reliable data, but 6 were from Democratic counties and 6 from Republican. 


\section{CLERKS}

Of the 67 county Clerks, I 6 were natives of Arkansas 5 came to the State in childhood, I 3 came prior to the civil war, 6 during the war, 9 immediately thereafter, and 6 in 1867 . Concerning the remaining Io $I$ have not been able to ascertain, but 6 were from Democratic and 4 from Republican Counties.

\section{SHERIFFS}

Of the 67 county Sheriffs, 20 were natives of Arkansas, 7 came to the State in childhood, I 4 came prior to the civil war, 2 during the war, 6 immediately thereafter, and 3 in 1867 . As to the remaining I 3 I have not been able to procure reliable information. However, 8 were from Democratic and 5 from Republican Counties.

\section{TREASURERS}

Of the 64 county Treasurers, I 7 were natives of Arkansas, I 2 came to the State in childhood, I 3 came prior to the civil war, 3 during the war, I immediately thereafter, and $I$ in $I 867$. As to the remaining I 5 I have no reliable information except that 9 were from Democratic and 6 from Republican Counties.

From the counties of Lafayette and Van Buren I have been unable to obtain reliable information concerning any of the county officers. The majority of the counties in which I am lacking in full information were Democratic, but it is not supposed that Mr. Fishback had in mind the officers of such counties when he spoke of "carpetbaggers." 
I would have the reader keep constantly in mind that he Democrats completely controlled the State Governsent from I 866 until the State Constitution was adopted under the Reconstruction Measures in $\mathrm{I} 868$, a period of two years. Therefore the few officers above mentioned who came to the State as late as 1867 did so when the Democrats were in full power, and before the officers to be elected or appointed, together with their salaries and emoluments, had been fixed by the State Constitution.

With a very few exceptions, the Northern men who settled in Arkansas came there with the Federal Army, and during the period of their services in the State were so much impressed with its genial climate and great natural resources as to cause them, when mustered out of the army, to make it their future home.

A number, like myself and my brother William, had contracted matrimonial ties.

Many of them had been away from home so long as practically to have lost their identity in the States upon the muster rolls of which their names were carried. These were the reasons that influenced their settlement in Arkansas at the close of the war rather than the existence then of any political expectations.

Perhaps the reader will think that I have devoted too much time to the refutation of a single person's assertions, but it should be understood that it is not only $\mathrm{Mr}$. Fishback I am answering, but also the entire Democratic party, for which he was spokesman.

The things here discussed and many others of a similar character have been told by the Democrats and so drilled into the masses of Arkansas that, in spite of their absolute falseness, many persons have come to believe them to be true. 


\section{THE SCARECROW OF NEGRO DOMINATION}

From the following sample of the tabular form used in obtaining the foregoing information, it will be seen that it also requested the names of the colored county officials, if there were any. This illustration of the replies received gives the county officers of Pulaski, the Capital County of the State, and was furnished by Hon. H. L. Remmel, member of the Republican National Committee, and Chairman of the State Central Committee.

\begin{tabular}{|c|c|c|c|c|c|}
\hline Name & Office & \begin{tabular}{|c|} 
White \\
or Black
\end{tabular} \mid & $\begin{array}{l}\text { Nativity or Date } \\
\text { of Immigration }\end{array}$ & Politics & $\begin{array}{l}\text { Length of } \\
\text { Service }\end{array}$ \\
\hline David Reeve & Co. Judge & White & $\left\{\begin{array}{c}\text { Michigan } \\
1863\end{array}\right\}$ & Republican & $I 868-I 872$ \\
\hline $\begin{array}{l}\text { G. McDiarmid } \\
\text { W. S. Oliver } \\
\text { John Reigler }\end{array}$ & $\begin{array}{l}\text { Co. Clerk } \\
\text { Sheriff } \\
\text { Co. Treas. }\end{array}$ & $\begin{array}{l}\text { White } \\
\text { White } \\
\text { White }\end{array}$ & $\begin{array}{c}1865 \\
\text { I } 865 \\
\text { Old Citizen }\end{array}$ & $\begin{array}{l}\text { Republican } \\
\text { Republican } \\
\text { Republican }\end{array}$ & $\begin{array}{l}\mathrm{I} 868-\mathrm{I} 872 \\
\mathrm{I} 868-\mathrm{I} 874 \\
\mathrm{I} 868-\mathrm{I} 874\end{array}$ \\
\hline
\end{tabular}

(Signed) H. L. Remmel.

Although Mr. Fishback does not mention Negro Domination in his publication,-or perhaps, more properly speaking, negro balance of power, - the Gazette and other publications exhibited this scarecrow to the best advantage for their purposes. From the information obtained from the circulars sent out, and from other sources, it developed that two negro members of the Senate and about a half dozen of the House were all the negro officeholders in the State, except a few below the rank of County Judge, County Clerk, Sheriff, and Treasurer.

When you remember that the Census of 1870 shows that the ratio of the negro population in Arkansas was only twenty-five per cent. of the entire population, it will be seen how groundless the charges were of threatened negro domination, and when you consider how utterly 


\section{8

helpless the negro population was as to educational facilities, labor conditions, money, and arms, and especially when you consider the terribly repressive efforts of the $\mathrm{Ku}$ Klux nightriders, it is not saying much for the chivalry of Arkansas to talk of Negro Domination!

To show the real purposes of the Ku Klux Democracy, I quote the following from the Gazette, of August 8, I 868 :

". . . Things have come to such a pass that it behooves the white people of the country to consider resolutely how the danger which threatens them is to be met, and it is not out of place to recommend to the negroes the consideration of their perilous situation, if they continue to act upon the counsels of their wicked advisers. In this connection we cannot say anything more to the point than to adopt and re-publish the following extract from an article in the Richmond Inquirer:

"Are we then indeed to have a war of races? Then let us prepare for it! We sound the note of warning to the people and bid them be on the alert. Preparation may be prevention, but if in spite of preparation the conflict be precipitated upon us, it can have but one conclusion. The negro element in the South is like a gangrene upon the body politic, and the first drop of blood shed in a servile war will be the signal for the extermination of the whole race. The white men of the Southern States will not always permit their land to be the scene of the successive depredations of Yankee bummers, carpet-baggers, and truculent negroes, and they must some day be relieved of the horrible ills which for years they have patiently borne. . .

" "The South wants peace, and if it is now to be required to wade through a sea of blood to reach it, the sooner commenced the sooner ended," 
In other words, the Democrats used this unsupported charge of Negro Domination, for all it was worth, to play upon the timidity and helplessness of the negroes by threats of extermination, and to justify their extreme Ku Klux outrages upon them. I hope the reader will not lose sight of the fact that this article from the Gazette was published in the midst of the very exciting and bloody presidential campaign of 1868 , and was clearly intended so to terrify the negro voters as either to cause them to remain at home on election day or to vote the Democratic ticket.

The information I have set forth as to the negro office-holders in the State is corroborated by a speech delivered by a prominent colored Democratic orator, of which the Gazette, in its issue of September 27, 1868, gives the following report:

\section{"THE SPEAKING}

"As we announced in Saturday's issue, John F. Harris, of Tennessee, the colored orator, who has recently been making a tour through the northeastern part of the State, where he has been doing good work for the Democracy, addressed a crowd of about 2,000 people,white and colored,-in front of Theatre Hall, on Friday night. . . .

"He reverted to the fact that not a single colored man had been appointed to any office of honor, trust, and profit in the State. ..."

The fact is that the negroes generally were not clamoring for offices. They only wished to be unmolested, and they were always for peace. This is shown from the following facts: When the Democrats came into power in 1874 there were eight counties along the Mis- 
sissippi River,-where the large plantations were located, -in which the negro population was largely in the majority. In those counties it would have been possible to elect a large percentage of negroes to office. But this would have seemed to justify the Democratic charge of negro domination and would have furnished them an excuse for Ku Klux depredations. Therefore it was considered more desirable to enter into a compromise.

The plan was to have the Republicans and Democrats hold their Conventions on the same day and each appoint a committee of conference to nominate a ticket which would divide the county offices equally between the two parties, and over which there would be no contest.

I was visiting my brother John on my plantation when the question was brought up, and I advised him to adopt the plan. The Democrats gladly agreed to the compromise, and it was applied to all the negro counties, except perhaps Phillips.

This agreement was honorably kept by the negroes, and because of the existence of the Enforcement Act, which protected the negroes in their rights, it was also kept by the Democrats.

But the day came when, through some evil influence, this Enforcement Act was repealed by Congress. Did the Democrats continue to respect the agreement that during all these years had been unbroken by the negroes? To their discredit, they did not! With one accord, regardless of every consideration of honor, they seized every office in sight.

\section{FOOTNOTES FOR CHAPTER XIII}

${ }^{1}$ Publications of the Arkansas Historical Association, Vol. I, p. 3 I9.

${ }^{2}$ Information was obtained from the War Department, Washington, D. C. 


\section{CIVIL WAR, IN ARKANSAS}

${ }^{3}$ Described in Chapter II.

${ }^{4}$ Letter in my possession from Treasury Department, Washington, D. C., under date of March I7, 1914.

${ }^{5}$ See pp. 358-360.

${ }^{6}$ On file in Library of Congress, Washington, D. C.

${ }^{7}$ See "Why the Solid South, or Reconstruction and Its Results," Chapter XI, Arkansas, pp. 294-295.

${ }^{8}$ Published in Memphis Evening Post, January 8, 1869.

${ }^{9}$ Dated June 3, 1913.

${ }^{10}$ Arkansas Laws, I868, p. I5I, Sec. 6.

${ }^{11}$ Arkansas Digest of Statutes, Gantts, p. 736, Sec. 4053.

${ }^{12}$ Arkansas Digest of Statutes, Gantts, p. 250, Sec. 707.

${ }^{13}$ Pp. 97-I 12, inclusive.

${ }^{14}$ See p. 198.

${ }^{15}$ Pp. 298-302, inclusive. 


\section{CHAPTER XIV}

\section{MY OCTOBER SPEECH}

From the speech referred to, delivered by me on October I 5, I869, and published in the Gazette, October I 7, of that year, I give the following extract:

“... The suffrage question is one that justly excites the attention of all Republicans. In my opinion, there is but one way to dispose of it, and that is for the party which conquered the rebellion, the party which magnanimously forgave the enemies of the Government and restored to them every lost privilege,-with the exception of the elective franchise, which has thus far been withheld from the leaders of the rebellion,- - should now be prepared to take steps in a Constitutional way to restore to them this lost privilege, and thus set at rest forever this vexed question. I hope you will bear in mind that, under the wise provisions of our Constitution, this cannot be hastily accomplished. If we should conclude to proceed now in that direction it would be years before it could be consummated.

"The qualified electors, under the [State] Constitution, must twice give their consent through their representatives, and once directly at the polls, before any amendment to the Constitution can become a part of the organic law. So, you see, the whole question will be finally in the hands of the people. Therefore, can anyone say that it is unsafe to move in this matter? I know 
that in announcing my views upon this question I am liable to be misunderstood by persons who jump at conclusions, and to be misrepresented by others who are actuated by selfish desires and unreasonable prejudices. To all such I say that time will show who are the true friends of the Republican party. It may be said that I have changed my views upon this question, but this is not so, for I have always maintained that disfranchisement was a temporary expedient, only to be resorted to while the necessity existed.

"Judge Wilshire will bear me out in this assertion, that when he and I made the first Republican canvass that was made in this State we both proclaimed and advocated the necessity of disfranchisement, but only as a temporary means of establishing a loyal State Government, pledging ourselves to the people that so soon as the necessity ceased to exist we would use our influence in the Republican party to remove all disqualifications. I believe the time has come when we should make good our pledges, for a loyal Government has been established, and, notwithstanding the trials it has passed through, it has fully demonstrated its power to maintain itself. To-day its authority is respected throughout the length and breadth of the State. Peace, quiet, and security reign everywhere. Should this state of affairs continue, I shall recommend to the next general assembly a proposed amendment to the Constitution in relation to the elective franchise, which I trust will result in a permanent and lasting peace, and in the establishment of that cardinal principle of Republicanism that all men are equal before the law and endowed with the same rights, privileges, and immunities. ..."

This speech at first produced a great sensation in all political circles in Arkansas. Looking back through a 
vista of about forty-four years, I can now plainly see that its delivery, though actuated by conciliatory considerations, was politically unavailing. It afterward became absolutely demonstrated that the ears of the Arkansas Democracy were completely sealed against any ameliorating overtures upon my part. This, I think, will be very evident when the following extract from the $G a$ zette, of October 9, I868, is read:

"At best the most important duty we have now to perform is to secure good government and turn the money-changers out of the temple. Before that is accomplished it is idle to attempt to foster the arts of peace. It is hence that matters pertaining to improvements and the development of the financial interests of our people have been accorded little space in our columns."

This shows very clearly that it was the Democratic policy to retard the progress of the Republican administration by every means within its power, and that all must remain in abeyance until the old régime could get into the saddle again.

The Democrats regarded the speech as a bid from me for their party support in the forthcoming Senatorial election. While it was utterly unavailing with them, it proved to be a fresh supply of ammunition to the administration dissenters, for as is true of all political parties ours contained the following classes: Those who, upon a false estimate of their greatness, become self-appointed leaders; others who had been disappointed in their aspirations for positions they were not qualified to fill; and still others who were chronic faultfinders. These men had already been looking around for some other camp than mine in which to pitch their tents.

The faction that represented the most radical wing 
of the Republican party in Arkansas, with Joseph Brooks at its head, had shown evidences of discontent for some time. Now, through him as its leader, the amendment proposed by me was openly and vehemently attacked.

Although I plainly stated the process through which the amendment would have to pass and the time which must elapse before it could become effective, the Democratic party fully expected that the probable turmoil in my own party, assisted by them, would grow so strong as to cause me,-like Senter, of Tennessee; Walker, of Virginia, and Gratz Brown, of Missouri,-finally to fall headlong into their arms.

The speech at first created much alarm among the Republicans, as they supposed it meant my election to and acceptance of a seat in the United States Senate, leaving Lieutenant-Governor Johnson as my successor. Having resolved that under no circumstances would I vacate the Executive Chair, if followed by such results, I freely gave my solemn assurances to that effect, which were generally accepted by my party friends.

Having given this assurance to my friend, General Catterson, which he rejected in terms that I considered a reflection upon my veracity, in a moment of unguarded passion I struck him. He did not return the blow and the moment after I left him I would have given a great deal to recall it, and I have always regretted it. Of course the result was that he joined my political enemies, and, as Marshal of the Eastern District of Arkansas, to say nothing of his great party reputation growing out of the Ku Klux War, the loss of his friendship was almost irreparable. I thank God that many years ago we resumed our friendly relations.

Although at first my speech gave the Democrats great satisfaction, afterward, when it was known that I had openly proclaimed that I would not accept the Senator- 
ship if it resulted in placing Lieutenant-Governor Johnson in the Chair, they charged me with breach of faith, which was not true, as I had at no time, either by word or inference, given them to understand that $I$ would pursue any other course than that proclaimed in my October speech. Notwithstanding this false charge, when the Senatorial election occurred I received ninety-four votes, ${ }^{1}$ which included all but six of the Democratic members in both Houses. Doubtless they hoped that as the breach between the Brooks faction and myself grew wider the situation would lead me to accept the Senatorship.

In view of the difficulties of Registration, ${ }^{2}$ supplemented by the promise made by me in my October speech, I sent to the Legislature on January 4, I 87 I, the following message : ${ }^{3}$

“. . . To so much of Article VIII as imposes political disabilities upon a portion of that class of our citizens that participated in the late rebellion I hope no one will understand that I am disposed to doubt the wisdom of the Constitutional Convention in their action respecting the elective franchise. On the contrary, I regard it as having been absolutely demanded by the exigencies of the times, and necessary to the establishment and maintenance of a State Government in harmony with the General Government, against which the people of the State had lately exercised all their powers of resistance.

"In a healthy condition of the body politic, when all its members act in harmony, to apply disfranchisement for political purposes would be in violation of the principles of pure Republicanism. It was only the unhealthy condition that characterized it at the time our Constitution was framed that justified such otherwise harsh and extreme measures. The surgeon will not hesitate to apply caustic to the most sensitive wound, if its unsound 
condition demands it; but to continue the application after the necessity ceases to exist will defeat the original intention and only tend to keep up an irritating and festering sore.

"I have always regarded disfranchisement as temporary in its nature, and have anxiously looked forward to the day when a sounder and healthier condition would justify its removal. More than one year ago [in my October speech, r869] I took occasion publicly to express myself on this question. I then foreshadowed the course that I would pursue, provided the then peaceful and healthy condition of affairs in the State should continue, and give evidences of permanency. The time that has intervened has only strengthened the convictions I then expressed, and I am now most happy to say that the present encouraging condition of affairs throughout the State in my opinion fully warrants me in carrying out the pledge $I$ then made. I therefore invoke your careful and dispassionate consideration of this important question, and earnestly recommend that you take the necessary steps by proposing an amendment to the Constitution, whereby the people may finally determine whether or not these disfranchising measures shall continue as they are, or cease to exist.

"Should you adopt this course, I earnestly hope and believe that you will take the initial step that will ultimately lead to permanent political tranquillity and to the restoration of those relations of comity and good feeling that should characterize citizens of the same commonwealth.

"I would also call your attention to the provisions of the Constitution by which the disabilities may be removed from many individuals by a two-thirds vote of the General Assembly, and I recommend that your honorable 
body take such action in all meritorious cases that may be brought before you."

The action of the Legislature in both Houses fully sustained my course-the vote in the Senate on the amendment being affirmative, I 8 ; negative, $6 ;^{4}$ and in the House of Representatives, affirmative, 65 ; negative, $3 .^{5}$ This amendment having passed through the successive stages required by the Constitution, and having been ratified by the people by a large majority, became what was known as Article VIII of the State Constitution. So, this Constitutional disfranchising provision, which originated with the Republicans, was by them repealed, a fact not generally understood by the Arkansas Democracy.

\section{FOOTNOTES FOR CHAPTER XIV}

${ }^{1}$ Arkansas House Journal, 1871, p 75. Arkansas Senate Journal, I 871 , p. 44.

${ }^{2}$ Described in Chapter IV.

${ }^{3}$ Arkansas House Journal, I871, pp. 35-36.

${ }^{4}$ Arkansas Senate Journal, I871, pp. 83-84.

${ }^{5}$ Arkansas House Journal, i87I, pp. 617-619. 


\section{CHAPTER XV}

\section{THE IMPEACHMENT}

On February 16, I871, when neither I nor any of my friends had the least suspicion of what was coming, the following resolution was introduced by Representative W. B. Padgett in the lower House of the Arkansas Legislature: ${ }^{1}$

"Whereas, Powell Clayton, Governor of the State of Arkansas, has been guilty of malfeasance in office and high crimes and misdemeanors, in this:

"First. That he has conspired with the members of the Supreme Court of the State of Arkansas to maliciously and unlawfully deprive Lieutenant-Governor James M. Johnson of his said office of Lieutenant-Governor, to which he was duly and lawfully elected by the people of the State of Arkansas, and for which he qualified, according to the constitution and laws of said State.

"Second. That he has unlawfully removed an officer of the county of Clark, in said State of Arkansas, to wit: N. H. Lock, county and probate judge of said county, from his said office, to which said office he, the said Lock, was duly and constitutionally elected by the people of said county.

"Third. That he directed, encouraged, and aided in frauds in the election of a Senator and three Representatives to the General Assembly, for the thirteenth district of the State of Arkansas, composed of the coun- 
ties of Hot Spring, Montgomery, Polk, and Scott, in said State of Arkansas.

"Fourth. That he has accepted pecuniary considerations for issuing bonds or obligations of the State of Arkansas to and in favor of the Memphis and Little Rock Railroad Company, in utter violation of law and disregard of his official duty as Governor of the State of Arkansas; also, he has accepted pecuniary considerations for issuing bonds or obligations of the State of Arkansas to and in favor of the Little Rock and Fort Smith Railroad Company, in utter violation of law and disregard of his official duty as Governor of the State of Arkansas.

"Fifth. That as Governor of the State of Arkansas he has issued bonds or obligations of said State to the Mississippi, Ouachita, and Red River Railroad Company when said company was notoriously not entitled to the same under the act of the General Assembly of the State of Arkansas, approved July 2I, I 868.

"Sixth. That he has been guilty of other misconduct and malfeasance in office and other high crimes and misdemeanors; therefore moved,

"First. That the said Powell Clayton, Governor of the State of Arkansas, be, and he is hereby, impeached of misconduct and malfeasance in office, and high crimes and misdemeanors, and that the said Powell Clayton be, and is hereby, suspended from exercising the functions of Governor of the State of Arkansas, in conformity to and with the constitution thereof.

"Second. That D. J. Smith, of Columbia County; F. M. Thompson, of Columbia County; B. B. Battle, of Hempstead County; A. Mason, of Calhoun County; E. A. Fulton, of Drew County; W. B. Padgett, of Independence County, and R. A. Howard, of Pulaski County, members of the House, be, and they are hereby, appointed 
managers on the part of the House of Representatives of the State of Arkansas to prepare articles of impeachment against the said Powell Clayton as Governor of the State of Arkansas, with full powers to examine witnesses and otherwise conduct the trial of the impeachment, in the name and on behalf of all the people of the State of Arkansas.

"Third. That said managers be instructed to go immediately to the Senate and at the bar thereof, in the name of the House of Representatives, and of all the people of the State of Arkansas, to announce the impeachment of Powell Clayton, Governor of the State of Arkansas, for misconduct and maladministration of his office, as such Governor, and acquaint the Senate that the House of Representatives will, in due time, exhibit particular articles of impeachment against him, and make good the same; and that the managers do demand that the Senate take order for the appearance of said Powell Clayton, to answer to said impeachment."

Under whip and spur the "previous question" was adopted, cutting off all debate, and the resolution was passed by a vote of 42 to $36 .^{2}$ Thereupon a Board of Managers was appointed, with instructions to proceed to the bar of the Senate and inform that body of the action of the House in the premises. ${ }^{3}$

In the meantime believers in fair play were not idle, and the Senate, after an adjournment for lack of quorum from day to day, from February 17 to February 24, re-

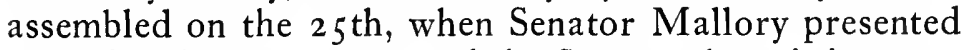
rules for the government of the Senate when sitting as a Court of Impeachment, which were adopted by a vote of I 8 to $6 .^{4}$ These rules were for the purpose of securing to the accused a prompt trial.

The position taken by the Board of Managers and 
its ultimatum are set forth in its report to the House, of which the following is a copy: ${ }^{\mathbf{5}}$

"We, the committee, selected to conduct the impeachment of his Excellency, Powell Clayton, Governor of the State of Arkansas, report as follows:

"In obedience to the instructions of your honorable body, given to us on the I6th day of February, I87I, directing us to proceed to the bar of the Senate and in the name of the House of Representatives and of all the people of the State of Arkansas announce that the House had impeached Powell Clayton, as Governor of the State of Arkansas, of high crimes and misdemeanors in office, and that we would in due time exhibit particular articles of impeachment against him and make good the same, we proceeded on three successive mornings immediately after said impeachment to the bar of the Senate, and were denied admittance or recognition. Finally, on the morning of the 20 th day of February, I87I, we were recognized, and announced at the bar of the Senate the impeachment aforesaid, pursuant to said instructions. After this announcement His Excellency was notified of his impeachment by the proper officer, as we are informed and believe, and within the time prescribed by law. We, therefore, contend and insist that all necessary notice of said impeachment hath been given and that we have thus far faithfully discharged our duties.

"Since and immediately after the impeachment aforesaid a majority of the Senators of this General Assembly have wilfully absented themselves from their places in the Senate for several successive days, without leave or sufficient excuse, with the intention, as we believe, of defeating or retarding the action of this House in the impeachment of His Excellency. Since the return of said absent Senators the Senate has adopted rules to govern 
them, when sitting as a court of impeachment, by which this committee would be prohibited in a trial of impeachment from arguing any preliminary or interlocutory question or motion, arising or made in the progress of said trial, exceeding ten minutes, unless the Senate should otherwise direct, and by which more than two of your committee would be prohibited from making a final argument on the merits, and occupying more than thirty minutes to each person so allowed to argue, unless the Senate, by order, should extend the time.

"We, therefore, conclude:

"First. That no fair trial of impeachment of the said Powell Clayton can or will be had before the Senate under their said rules.

"Second. That any trial of impeachment of the said Powell Clayton before said Senate under said rules will be a farce.

"We, therefore, respond to the resolution adopted by this House requiring your committee to again appear at the bar of the Senate and announce the impeachment of Powell Clayton, Governor of the State of Arkansas, by saying that we are willing to again announce said impeachment at the bar of the Senate on the following conditions, to wit :

"First. That we shall be assured that any articles of impeachment preferred against the said Powell Clayton, as Governor of the State of Arkansas, will not be considered invalid, set at naught, or dismissed by the Senate, because notice was or has not been given to them within the time required by law.

"Second. That the Senate will give your committee at least twenty days in which to prepare particular articles of impeachment against the said Powell Clayton and at least thirty days from second announcement or notice of said impeachment in which to produce the evidence to 
sustain the same, and all continuances necessary to obtain important testimony failed to be obtained after the use of reasonable diligence to obtain the same.

"Third. That the Senate repeal rules twenty and twenty-one of the rules adopted by them for their government in impeachment trials and grant to us an unlimited right of argument and debate of all questions and issues of law, fact, and evidence arising in the progress of the trial of impeachment of said Powell Clayton, as Governor of the State of Arkansas.

"And that unless said conditions are granted we are unwilling to act as a committee selected as aforesaid, and respectfully ask that we be discharged as such committee and that others be appointed in our stead, who may be or are willing to act as such committee. In making this request we recognize the right of this House to instruct, at all times, its committees."

The facts were that on the three successive mornings mentioned in the report they proceeded to the Senate Chamber and found that body not in session by reason of the lack of quorum before mentioned. The validity of the presentation made on the 25 th of February, I $87 \mathrm{I}$, no one questioned.

The last two sections of their report clearly show that their demands were based upon the idea of protracted delays to furnish time for the conspirators to carry into effect their purposes. The House, doubtless, saw through their thinly veiled pretext, and promptly excused them from further service, and appointed a new Board, composed of C. B. Neal, Charles Minor, and Joseph A. Meek,-all Democrats. ${ }^{6}$

This new Board of Managers entered at once upon the discharge of their duties. After having exhausted all their efforts to obtain sufficient evidence upon which to 
base particular articles of impeachment, they so reported to the House on March 4, I87 I. The following is a copy of said report, which, with the resolution therein submitted, was adopted by a vote of 49 to $18:{ }^{7}$

"Mr. Speaker: The committee appointed by this honorable House as a board of managers to prepare particular articles of impeachment against His Excellency, Powell Clayton, Governor of the State of Arkansas, and to exhibit and make good the same, did, in obedience to the order of this House, immediately proceed to the bar of the Senate and did there give notice that they wourd in due time exhibit particular articles of impeachment against said Powell Clayton, Governor of the State of Arkansas; and the committee have made every effort within their power to obtain information to enable them to prepare such articles of impeachment for the consideration of this House.

"The Committee addressed to the honorable board of managers heretofore appointed by this House in this behalf a letter, and delivered the same to the honorable chairman of said board the day it bears date, a copy of which letter is hereto annexed, respectfully requesting said board of managers to furnish this committee with the testimony, the names of all witnesses on behalf of the State in the case of impeachment against His Excellency, Powell Clayton, together with the residences of said witnesses, and the committee have not as yet received the desired information.

"The committee, as a board of managers, have used their utmost diligence to learn such facts as the committee are of the opinion must be learned in order to exhibit particular articles of impeachment against His Excellency, the Governor, with a dignity becoming this honorable House; and have carefully sought informa- 
tion of parties who the committee had reason to believe were in possession of or conversant with the facts and evidence necessary to conduct the trial of his impeachment successfully, and have failed in their efforts.

"The committee have also examined with care the records of the office of the honorable, the Secretary of State, which have a bearing on the issuing of State bonds to the Mississippi, Ouachita, and Red River Railroad Company, in connection with the acts of the General Assembly of the State of Arkansas, with reference to issuing State bonds to railroads, and are of the opinion that there is not sufficient evidence to convict His Excellency of misdemeanor in office.

"The committee, having made these unsuccessful efforts to procure the necessary evidence or information, have to report that they have failed to obtain any facts as data that would warrant them in attempting to prepare particular articles of impeachment against His Excellency, Governor Powell Clayton.

"When these grave questions were presented to this House, some fifteen days ago, this House was assured that there was ample testimony at hand to sustain the charges therein set forth, which could be obtained at any time, and would be furnished on application, with a full and complete statement of facts that could be proven on trial, which would have enabled the committee to prepare particular articles of impeachment upon such statements.

"The committee are now informed by some that there is certain evidence in the city of New York and other places that will sustain the charges. From others, by whom we were informed of the abundance and sufficiency of proof at hand, the committee can get no information whatever. And such information as the committee have been able to obtain is in the opinion of the committee 
entirely inadequate to sustain the charges against the Governor, and too frivolous to attempt a further prosecution of this case.

"And believing as we did, when we voted to impeach Governor Clayton, that it is not only the right but the sworn duty of a Representative of the people to protect their rights by a thorough investigation of the official acts of their servants, however high the position they occupy, we here take occasion to say, with the lights then before us, we would do so again.

"The committee entered upon a discharge of the duties imposed upon them with a full determination that to the best of their ability they would vindicate the rights of the people; but, while they are ready and willing to vindicate the people's rights, they are unwilling to prosecute this case further when they have no grounds to believe that they can, from any proof within the knowledge or reach of the committee, prosecute this case to a successful termination.

"In view of the facts above stated, and the further fact the people demand at our hands such relief as we are able to give by legislation, the committee would respectfully recommend the adoption of the following resolution:

"Resolved: That further proceedings in the impeachment of Powell Clayton be dispensed with, and that the action of this House heretofore taken be set aside and cancelled; that the Senate be informed of the action of this House in the premises by the clerk of the House, and that the committee as the board of managers be discharged."

The primary object of the impeachment proceedings was to cause my suspension from office, the induction of Lieutenant-Governor Johnson to the Gubernatorial chair, 
and such delay in the prosecution of the impeachment that I would have remained indefinitely out of office, while my enemies worked out their ulterior purposes.

The disastrous failure of this whole conspiracy greatly strengthened me with my party, as is shown by the results of my second election to the United States Senate, which occurred on March I5, I87 I, when I received a two-thirds majority on joint ballot: all Republicans,- 18 votes in the Senate ${ }^{8}$ and 42 in the House. ${ }^{9}$

\section{FOOTNOTES FOR CHAPTER XV}

${ }^{1}$ Arkansas House Journal, 187 r, pp. 369-37r.

${ }^{2}$ Arkansas House Journal, i 871, pp. 37 I-372.

${ }^{3}$ Arkansas House Journal, I87 I, pp. 376-377.

${ }^{4}$ Arkansas Senate Journal, I 87 I, pp. I88-189.

${ }^{5}$ Arkansas House Journal, I871, pp. 512-514.

${ }^{6}$ Arkansas House Journal, I871, p. 519.

${ }^{7}$ Arkansas House Journal, 1871, pp. 538-541.

${ }^{8}$ Arkansas Senate Journal, 1871, p. 273.

${ }^{9}$ Arkansas House Journal, I871, p. 7 I6. 


\section{CHAPTER XVI}

\section{MY SENATORIAL INVESTIGATION}

I now come to a question which gave me much trouble but which in the end, in the investigation of my right to a seat in the United States Senate, led to my most triumphant vindication and the complete downfall of my political enemies.

At the fall election of i 870 illegal polls were set up in Pulaski County for the purpose of electing Joseph Brooks, James L. Hodges, and other political enemies of mine to the State Legislature.

The election for Representatives to Congress was held at the same time, and in the district of which Pulaski County was a part the candidates for the Lower House of Congress were John Edwards, Democrat, and Thomas Boles, Republican. Some time after this election, but before all the returns had been certified to the Secretary of State, information came to me from the very highest sources (being no less than from the Supreme Court and the Legislative Department of the State) which satisfied me that what purported to be returns in the office of the Secretary of State for eight precincts in the county of Pulaski were the returns of bogus elections, and consequently were no returns at all in the legal acceptation of the term.

In three of the precincts referred to, two sets of polls were held, - one by the legally appointed officers, and the other by persons who, under false pretenses, usurped 
the lawful authority and held illegal elections. Manifestly both polls could not have been legal, since the law only authorized one set of polls in each precinct. The county clerk, who was a party to the frauds, certified to the Secretary of State the returns of the unauthorized judges, and declined to certify the returns of the regular judges.

Upon a writ of mandamus the case was heard by the Supreme Court of the State and a decision was rendered, with the concurrence of the full bench, that the elections held by the judges appointed by the Board of Registration were the legal elections, and that the others were illegal and void; and the county clerk was compelled to certify the returns accordingly.

Thus we had in the office of the Secretary of State what purported to be two sets of election returns for the three precincts referred to, and in the exercise of what I conceived to be not only a wise discretion but my sworn duty I discarded the returns of the election declared illegal and void by the Supreme Court.

A short time after the assembling of the Legislature, which had been chosen at this election, a resolution was passed by both Houses and a joint committee appointed to investigate the election frauds I have referred to. In their report, made to the Legislature on February i I, I $87 \mathrm{I},{ }^{1}$ they gave a detailed account of the result of their investigations and declared it to be the opinion of the committee that the elections held in the precincts alluded to should be declared void.

Thus the legislative department and the State Supreme Court concurred in the decision that the elections so held were null and void. In accordance with these decisions the returns from these elections were excluded from the count, and by this act it appeared that John Edwards was elected to Congress from the Third Con- 
gressional District of Arkansas; therefore on the 2oth of February $I$ issued a proclamation ${ }^{2}$ giving to Edwards a certificate of election. "The head and front of my offending hath this extent, no more." For this I was indicted by the United States Court.

As an election for a Senator to Congress was soon to take place in Arkansas, the opposition to the administration gave forth statements that the certificate of election was issued to John Edwards, Democrat, in pursuance of a trade, whereby $I$ was to receive the support of the Democratic members of the Legislature for my election to the United States Senate.

Prior to this I had been elected to the United States Senate, but had declined the election for the reason that the Republican party felt that its interests would not be safe in the hands of the Lieutenant-Governor. However, during the interim between my first and second Senatorial election an arrangement took place which resulted in White's resigning the office of Secretary of State and the Lieutenant-Governor's being appointed in his place. In connection with these changes I was charged with having contributed money and bonds to secure White's resignation.

I did not formally answer this charge during the investigation in the United States Senate. I had taken the floor to do so when Senator Hitchcock, of Nebraska, came to me and urged that I should not enter upon the discussion of that particular point lest it might result in the re-reference of the report to the committee and thereby delay the proceedings,-already unreasonably prolonged,- when at that moment an ample number of votes could be had to insure the passage of the majority report.

With the exception of stating that I was ready to go before the bar of the Senate and take oath that I had not 
contributed any money or bonds for Mr. White, I immediately accepted Senator Hitchcock's suggestion.

I now take this occasion to say emphatically that I contributed neither money nor bonds to the fund raised and held by Jackson E. Sickels for Mr. White. Senator Hadley, who participated in the arrangement for White's resignation and who became Lieutenant-Governor in the place of Johnson, is still living and can bear witness to this statement.

I was told by Jackson E. Sickels that the money and bonds to indemnify Secretary White against the loss of his railroad interest, should he resign, were contributed by Mr. Sawin, the contractor for the building of the Mississippi, Ouachita, and Red River Railroad.

The contractors for the various railroads aided by the State were entirely dependent upon the sale of State Aid bonds for the completion of their work. Therefore, they had become very much alarmed by Lieutenant-Governor Johnson's expressions of hostility against State Aid to Railroads, and by his open espousal, in his "Serenade Speech" published on pages 265-269, of the course pursued by Governor Senter of Tennessee, Governor Walker of Virginia and others, in what was termed the "sell-out" of those States to the Democracy.

They realized that Johnson's accession to the governorship would be fatal to their interests, and for selfprotection the indemnifying fund for Secretary White was raised.

Whether Mr. Sawin was assisted by others in a similar position I do not know, but I believe the reader will agree with me that, under the circumstances, this action was entirely justifiable.

Secretary White testified before the Investigating Committee that his railroad interest, against the loss of which the fund was raised, was confiscated, as he had 
feared it would be, and that thereafter the indemnifying fund was turned over to him.

The only connection I had with the transaction was to assure Secretary White that should he lose his railroad interest through his resignation, I would exert my influence to see that the arrangement to indemnify him was faithfully carried out.

On the I 5 th of March, I $87 \mathrm{I}$, about one month after the issuance of the certificate to Edwards, I was again elected to the United States Senate ${ }^{3}$ by a two-thirds majority on joint ballot. At this second election, in direct refutation of the charge that $I$ had issued the certificate to Edwards to secure the support of the Democratic members, but one Democrat voted for me in both Houses. I can only account for his vote by the fact that he was a Methodist preacher and a conscientious man!

Upon my going to Washington, O. A. Hadley, who was president of the Senate, became acting Governor of Arkansas. When I took my seat in the United States Senate the Joint Committee to "Inquire into the Condition of the Late Insurrectionary States," of which Arkansas was one, was in session at the Capitol, and in September, I 87 I, it examined Edward Wheeler and William G. Whipple, both of Arkansas. In the report of this Committee, made on January 9, I 872 , the following language is used : 4

"The testimony of these witnesses (Wheeler and Whipple) tends to impeach the official character and conduct of a member of the United States Senate from the State of Arkansas, and also to affect the right of a member of the House of Representatives from that State to retain his seat in the House.

"Other evidence of the same character was offered, and one of the gentlemen affected by this testimony claimed 
the right to bring witnesses before the committee to contradict or explain the same. (Why did not the Senator state that it was I who made the demand to be heard before that committee and was refused upon the ground that they were about to close their work?) The committee, however, upon consideration, decided that the subject-matter to which said testimony related did not come within the limits of the investigation they were directed to make, and therefore declined to prosecute the inquiry any further, discharging a witness who had been subpœnaed and was then awaiting examination. The joint select committee, pursuing what it deemed the proper parliamentary course, at a meeting on December 2I, I $87 \mathrm{I}$, adopted the following resolution:

" "Resolved: That the committee report the testimony taken before it, affecting Senator Clayton and Mr. Edwards, a Representative from Arkansas, to the Senate and House of Representatives, with a recommendation that each House take such action as it may deem proper.'

"Agreeable to this resolution of said joint select committee, the undersigned Chairman on the part of the Senate and the Chairman on the part of the House of Representatives beg leave to submit the testimony of Edward Wheeler and William G. Whipple, both of the State of Arkansas, said Wheeler and Whipple having been the only witnesses from that State who were examined by the committee, to the Senate and House of Representatives, for such action as each House may deem advisable."

After the above recommendations had been submitted to the Senate, Mr. Scott, the Chairman on the part of the Senate, made the following explanation:

"The testimony directed to be reported covers over thirty pages and the Senate would not listen to that now, 
but it is due to the Senator (Mr. Clayton) who is implicated by this report that I should make a very brief statement of the reasons that have induced the committee to make the report.

"The witnesses who were called were called primarily with reference to some judicial proceedings that were then pending in Arkansas. Their testimony revealed the fact that indictments were pending in that State against Senator Clayton, which were not yet tried. Since the time these witnesses were examined before the committee the indictments have been dismissed in that court, not upon a trial but upon a demurrer to the indictments. . . . Other incidental testimony was elicited; but the point which struck the committee as requiring them to take the course which they did, presented briefly, was this: It is charged that Senator Clayton, as Governor of Arkansas, made a bargain with the Democrats in that Legislature that he would disregard the returns of the election upon file with reference to the candidates for Congress,- $-\mathrm{Mr}$. Edwards and Mr. Boles, - and issue a certificate to Mr. Edwards, the returns showing $\mathrm{Mr}$. Boles to be elected, in consideration of the support of the Democratic portion of that Legislature for the office of United States Senator." 5

Thus it was that these unfounded charges were brought before the Congress of the United States, and that, too, in the face of the decision of the Supreme Court of the State and the Legislative Department. It merely goes to show that I was to be discredited and cast off, no matter what methods were resorted to, on the mistaken principle, I suppose, that "the end justifies the means." This was only one of a series of similar attempts, and its complete and ignominious failure proves that right will triumph in the end. 
After the report was read and $\mathrm{Mr}$. Scott had made the remarks above quoted, I said: "As I am the Senator implicated in this testimony, and as I do not care to lie under imputations one day longer than can possibly be avoided, I ask of the Senate unanimous consent to proceed to the present consideration of the report." ${ }^{6}$ The consent of the Senate was obtained and I addressed that body on the subject matter of the report, and in closing requested a full and thorough investigation, in the following language: "I ask of the Senate that an opportunity may be afforded me to defend myself against the aspersions of two political, and I may say personal, enemies; for the assaults made upon me by them and their coadjutors transcend the ordinary rules of political warfare. Since investigation is the order, let us have one in this case that will allow both sides to be heard; and if in the course of that inquiry it shall be found that improper acts or motives attach to me, then so be it. Let the Senate know it and the country know it; but if, upon the contrary, it shall be found that the dart which has been hurled at me by the hand of vindictive malice shall fail to reach its mark, or, like the Australian boomerang, shall return to lacerate the hand that projected it, then let that fact be made known and let the responsibility rest where it belongs. I ask, Mr. President, for a special committee clothed with the necessary powers to carry out the object of this inquiry." 7

Immediately after these remarks $\mathrm{Mr}$. Wright offered the following resolution: "Resolved: That the report of the committee and the testimony accompanying be referred to a special committee of three, with powers to send for persons and papers, to investigate and report upon the charges therein contained against Hon. Powell Clayton, a member of this body." 8

This resolution was considered by unanimous consent, 
and agreed to, and the appointment of the committee was left to the Chair, who named as such committee $\mathrm{Mr}$. Wright, Mr. Morrill, and Mr. Norwood.

The investigations of this special committee were begun on the I8th day of January, I872. James L. Hodges, of Arkansas, obtained leave of the committee to prosecute the charges before them, and I was present in person and by my counsel, Hon. Thomas M. Bowen and Hon. John McClure, both of Arkansas. The committee held almost daily sessions from the day last named until and including the 14 th day of May, when the testimony was closed. During that time they examined thirtyeight witnesses, whose testimony covered about 5,000 manuscript pages. Much of this testimony was absolutely irrelevant, as will be seen from the following extract from the majority report: ${ }^{9}$

"We are justified in saying that much of it was taken and received de bene esse. In other words, for the prosecution it was claimed that they would be able to show certain combinations, conspiracies, and corrupt agreements which, if established, would make such testimony competent and relevant. For the defense it was insisted that this state of case could not be shown, and in no event could such testimony be admissible under the resolution of the Senate and the matter submitted for our investigation, but in view of the possibility of its being so held, they submitted their testimony to meet the case supposed by the prosecution."

As the taking of the testimony in the case was not completed until the I 4 th day of May and Congress adjourned on the Ioth of the next month, there was not sufficient time for the special committee to examine the mass of testimony and make a report before the adjourn- 
ment, and the matter was carried over to the next session of Congress, which assembled on the $2 \mathrm{~d}$ of December, I 872 .

On the 26th of February, I 873, Mr. Wright, Chairman of the Special Committee, asked and obtained leave to submit the report of the committee on the charges against me. In presenting the report he made the following remarks : ${ }^{10}$

"I present the report of the Select committee appointed in January, a little over a year ago, to inquire into certain charges against Hon. Powell Clayton, a Senator from the State of Arkansas. In view of the length of time since the appointment of the committee I think it due to the committee and the Senate, if not to the country, that I should make a word of explanation. We entered on the discharge of our duties immediately upon our appointment. We devoted from two to three hours each day to the investigation. The testimony was closed near the adjournment of the last session. Being unable to examine all the testimony before the last session of Congress adjourned, we made a partial report. ${ }^{11}$

"Immediately upon our re-appointment at this session we entered on the discharge of this duty and have examined the entire testimony (about 5,000 pages) for the purpose of determining what was admissible and what was not. This has necessarily taken days and weeks, and only now have we concluded the examination of such testimony and determined what was admissible under the rule thus established. I submit the majority report, with the accompanying testimony."

In this report, in referring to the charges under consideration, Mr. Wright said: "As there are no specific charges in the report itself, the testimony of the witnesses 
must stand alone in the place of charges, the information, or indictment. Than this few things could be more indefinite or unsatisfactory; so entirely wanting in everything approximating conciseness, clearness, or definiteness." 12

Further on he said: "As we read the record, Senator Clayton received a clear majority in each branch of the General Assembly, outside of those claimed to be fraudulently elected, and some of those whose elections are thus assailed, voted against him, and this alone is all that need be stated upon this subject. So it only remains to inquire into the alleged frauds connected with the election. And here the principal if not the only one is that Senator Clayton issued to Hon. John Edwards a certificate of election to the House of Representatives of the present Congress, upon a corrupt bargain or agreement that he was to receive in return for the same the support of the Democratic members of the General Assembly. If this charge is not sustained we hazard but very little in saying that there is nothing left of this case, and a brief statement will show how utterly groundless it is in fact." 13

"By the decision of the Supreme Court and the report of the committee in the Legislature the elections held by the regular judges were determined to be the only legal ones, and following these decisions the Governor gave the certificate of election to Edwards. It would certainly be most extraordinary to say that the Executive of a State may not follow the decision of its highest judicial tribunal, - that he may not act upon the proceedings of the Legislative branch." 14 "But this is not all. General Edwards was given the certificate on the 2oth of February, I87 I. Governor Clayton was not elected until the 15 th of March. He did not receive any votes under any such agreement, and least of all any number sufficient to influence the result." 
"Hence, we conclude that nothing could be plainer or more manifest than that this charge is totally and entirely unsustained!" 15 "What he wanted was not votes, for he had them, but he wanted such a condition of things as that he could take the office and keep faith with his friends." 16

He concluded his report with the following resolution: "Resolved: That the charges made and referred to the select committee for investigation, affecting the official character and conduct of the Hon. Powell Clayton, are not sustained, and that the Committee be discharged from their further consideration." 17

No immediate action was had on this report, and the minority committee asked and obtained leave to present its views, which was done on March I, I $873 . .^{18}$ This report of the minority, presented by Senator Norwood, was based largely on the testimony of one W. H. McConnell, concerning whom Mr. Wright, in the majority report, gave forth the following statement:

"One witness (McConnell) undertakes to bring all the matters detailed by him, or many of them, home to the Senator. But we feel bound to say that, in many respects, his story is improbable, and he stands before us in such an attitude that we are constrained to discredit much that he says. While before us he was almost a wreck from long continued dissipation, and we were compelled to put him under treatment for several days before his testimony could be completed. It seems to us that no tribunal would be justified in condemning anyone upon the mere recollections of such a witness months after the transactions occurred." 19

During the proceedings in the Senate, Mr. Cameron, a Senator from Pennsylvania, made the following statement concerning the witness McConnell:

"Mr. President, as the doors are now open and what 
I say will be put before the public, I desire to state that I was told to-day for the first time that an important witness in the case of the Senator from Arkansas (Mr. Clayton) is a person called McConnell, and I learned, too, that he belonged to the State which I have the honor in part to represent. He belongs to a very respectable family there, a family of great ability. Nearly all of them have great talents, but sometimes they do not use them for the best purposes, though most of them, I think, do. He is a native, I think, of the town of my colleague. But I remember this of him, that he is perhaps the most unreliable man that ever was born in the State of Pennsylvania. We have some bad men there, but I do not think anybody quite so bad as he.

"I desire to tell you only one or two facts in regard to his conduct. Some years ago there was a gentleman, Governor of the State of Pennsylvania, who was not particularly my friend, and if I were to mention his name you would think he never was my friend, and I ought not to defend him here. But he had, among other good qualities, the quality of hospitality. One evening a person came into his house without any invitation, and made himself exceedingly agreeable to everybody there, on the occasion of a party of ladies and gentlemen. He made himself so agreeable that he attracted everybody's attention. After a while, about the time he ought to have gone away, he suddenly became very sick and asked the hospitality of the governor's family to remain there all night. He remained all night. The next morning he was still sick, and he remained sick for four or five days. In the meanwhile he stole the affections of the governor's daughter, and he stole out one evening and got the justice of the peace to marry them. Of course the governor, and especially his excellent wife, were terribly shocked that a person of that kind should become a member of their 
family; but on his return, immediately after the performance of the ceremony, he was driven out of the house. The Legislature met directly afterward. So much wounded in his feelings was the governor that he went to Cuba and remained there until the Legislature divorced them, and this young man went out into the world again. After a while I heard of him in Philadelphia, and he committed about the same sort of an act in Philadelphia, in the house of a friend of mine.

"I therefore desire to say now, as I cannot be here to-morrow, that I should place no more reliance upon the word of that man than I would upon the word of a man who had been a hundred years in the penitentiary, for I think the fellow ought to be there at least half of that time." 20

Senator Scott, Senator Dorsey and others also testified as to his utter unreliability and declared that his testimony should be entirely disregarded.

The session of Congress adjourned on the $3 \mathrm{~d}$ of March, two days after the minority report was made, so no final action could be had, but on the closing day Mr. Wright, Chairman of the Committee, gave notice that he would call up the report at the earliest possible moment at the next session of the Senate and press for immediate action.

A special session of the Senate convened on the following day, the 4th, and on the I Ith of March, in accordance with the notice given by Mr. Wright, he again offered the resolution that the charges were not sustained and that the committee be discharged. However, action was postponed from day to day, at the instance of the minority, until on the $25^{\text {th }}$ day of March, 1873 , the report and resolution went to vote and was adopted, 33 voting in the affirmative and 6 in the negative. ${ }^{21}$

So, while my political enemies succeeded in placing me 
in this defensive position during one year of my Senatorial services, their malign purposes were finally and completely frustrated by this action of the United States Senate.

R. F. Catterson, United States Marshal, and W. G. Whipple, United States District Attorney, had been removed from their respective positions by the President; Catterson for alleged participation in the election frauds in Pulaski County in I 870,- - frauds that I have described, -and Whipple for undue partisanship. B. F. Rice, a United States Senator from Arkansas, was supporting these two officers and using all his influence to have them reinstated.

He had so poisoned the minds of the Republican Senators in Congress, - with tales of how I was forming alliances with the Democrats and selling out the Republican party in Arkansas, and of how the removal of these two federal officers was made because of their connection with the indictment brought against me,- - that when I took my seat in the Senate I was accorded a very cool reception.

If it had not been for this antagonistic atmosphere, created by the misrepresentations of Senator Rice, I would probably have contested in the Senate the reference of testimony taken before the $\mathrm{Ku}$ Klux Committee to the United States Senate. As it was, I decided to ask for the investigation that my enemies were so anxious to have made.

I had recommended the appointment of Isaac Mills and S. R. Harrington to succeed to the respective positions formerly held by Catterson and Whipple. Rice used every means at his command to induce the President to withdraw these nominations and reinstate Catterson and Whipple, but without success. However, the Senate supported Rice by holding up their confirmation. 
When Rice found that he could not fully control these Presidential appointments he called a meeting of the State Central Committee of Arkansas, ${ }^{22}$ of which he was Chairman, and went down to Arkansas to get the full support of that organization to further his plans and purposes. When the committee assembled he used every means to gain the co-operation of a majority of that body. $\mathrm{He}$ resorted to subterfuge to keep one member who was known to be my friend from attending the meeting, and he voted a proxy that had been given to him and afterward withdrawn ${ }^{23}$ when it became known what he was trying to do.

Notwithstanding all the questionable methods he used to carry the committee, he found that he was in the minority and the Chairmanship of the State Central Committee was wrested from him and given to me.

This placed him and his followers in a desperate situation and resulted in the organization of the Liberal Republican party in Arkansas. Rice, as chairman, issued a call for a State Convention, which met and elected delegates to the Liberal Republican National Convention, to be held in Cincinnati in May, I 872, where they supported the Greeley and Brown Presidential ticket.

Some time later the Democratic party in Arkansas held its State Convention and adopted, as their own, the platform and ticket headed by Joseph Brooks, of the Liberal Republican Convention held at Little Rock, and also the platform of the Liberal Republican National Convention held at Cincinnati. The delegates selected by them to attend the Democratic National Convention were instructed to give their support to the Greeley and Brown ticket. ${ }^{24}$

When that convention met in Baltimore on July 9, 1872 , it decided in favor of the Greeley and Brown ticket and combined its strength with that of the Liberal Re- 
publican National Convention for its success. Thus the combination was both State and National.

B. F. Rice attended the Convention held in Cincinnati, and when that fact became known it was a revelation to the President and the United States Senate of his real sentiments. They realized then that if the Republican party in Arkansas were sold out, I would not be the one responsible for it.

The confirmation of the federal officers, which had been held up so long, was immediately made.

This exposure of Rice's motives had the effect of making me solid with the Administration and with the Republican United States Senators, and put me in complete control of the situation at home. I was made the referee for Arkansas for all federal appointments in every department of the Government.

I headed a full delegation to the Republican National Convention, held in Philadelphia in June, I 872, where we gave our undivided support to the Grant and Wilson Presidential ticket, and where I was made the Republican National Committeeman from Arkansas, which position I held continuously, with the exception of about two years, until and including I9I 2 , when I voluntarily resigned.

The following is a copy of the resolution passed by the Republican National Committee, on the acceptance of my resignation:

"RESOLVED: That it is with sincere and profound regret that we accept the resignation of General Powell Clayton, who, for a period of forty years, represented the State of Arkansas upon this Committee, except for a brief interim of two years. For many years he was the Senior, or Dean, of the Committee. His State organization would have retained him on the Committee to the end 
of his days, but declining health and extreme feebleness demanded his voluntary retirement.

"RESOLVED: That the good wishes of the Committee be extended him, as also their high appreciation for his long, honorable, and patriotic services as one of its members.

"RESOLVED: That these resolutions be made a part of the record, and a copy mailed to the General at his present address by the Secretary."

This resolution was adopted by a unanimous, standing vote of the Committee.

OVERTHROW OF THE REPUBLICAN PARTY IN ARKANSAS

The long-drawn-out Senatorial Investigation, during which any enemy was at liberty to come in and discharge his rusty weapon at me and my friends, had occupied so much of my time in Washington that I had, to a certain extent, neglected political affairs at home, where conditions were such as now seriously to threaten the overthrow of the Republican party as the governmental force in Arkansas.

Under the most favorable circumstances, with the party united, our majority of the registered voters had always been small. Upon the formation of the Liberal Republican party and their nomination of a State ticket our forces became largely divided. Their nominee for Governor was Joseph Brooks, and upon their alliance with the Democrats, heretofore described, he became the representative of both parties.

Shortly after Mr. Brooks was selected the regular Republican party held its State Convention for the purpose of naming a State ticket, and Judge Baxter was nominated for Governor. This selection was largely a matter 
of expediency, as Judge Baxter was an old resident of the State and had been a slaveholder. Mr. Brooks had been previously very unpopular with the Democratic party; in fact, with the exception of myself, he perhaps was with them the most unpopular man in the whole State.

It was hoped by the regular Republicans that this fact would cause a number of the Democrats to support Judge Baxter. We believed that although he was a candidate on the Republican ticket he would be more acceptable to them than Mr. Brooks.

Judge Baxter was not a man of strong or decided character, as will be shown from the fact that when the war broke out he conceived the idea of remaining neutral while the great Civil War was fought out around him. This resulted in his being confined in the penitentiary by the Confederates, where he remained until he was liberated by the Commanding General of the Federal Army. It was then that he became allied with the Republican cause. When I became Governor I made him Judge of the Third Judicial District of the State.

Not long after Judge Baxter's nomination, while he and I were campaigning together, I discovered duplicity in his dealings. We traveled from day to day in the same buggy and stopped at the same hotels. He worked with me during the day and at night he was having secret conferences with the Democrats, and was making pledges to them which he had no authority to make for the Republican party.

It then dawned on me that we had made a bad political deal. If we did not elect Judge Baxter, we were defeated; and if we did elect him, we were also defeated, which in the end proved true.

When the election took place in November, I 872 , Judge Baxter was declared elected, and he was inaugurated on January 6, I873. Mr. Brooks contested the 
election before the Legislature, which decided against him. Proceedings were then instituted by him in the Supreme Court by quo warranto, but that body decided it had not the power to try the case.

On June I6, I873, he brought suit in the Pulaski Circuit Court, claiming the office of Governor, and the case was carried over until the following April, nearly one year, during which time Governor Baxter was in full control of the Governorship.

On April 15, 1874, the case was called, and Judge Whytock entered a final judgment, declaring that Brooks was entitled to the office of Governor and that Baxter should be ousted. Mr. Brooks procured a copy of the judgment and went directly to the Governor's office. He ejected Governor Baxter and took possession.

Governor Baxter immediately took refuge in the Headquarters of the Democratic party and set up an establishment there, and thereafter he was the complete and subservient tool of that party.

When this news flashed through the State it was the signal for one of the most disgraceful happenings that ever took place in American politics. Each party now espoused the cause of the candidate of the opposition, and the whole situation was completely reversed. The majority of the Republicans deserted Governor Baxter and went to the support of Mr. Brooks, and Mr. Brooks' original supporters now championed the cause of Governor Baxter.

Upon the call of the two candidates, armed men representing both sides of the contest flocked to the capital, and a conflict was avoided only by the intervention of United States troops. The situation was telegraphed to Houses of the Arkansas Legislature, President Grant, on Washington, and in response to an appeal from both 
May 15,1874 , issued a proclamation declaring in Governor Baxter's favor. ${ }^{25}$

This "war" was made the subject of an investigation by a United States House Committee, known as the Poland Committee, and a large mass of false testimony was given against me. As Chairman of the State Central Committee I felt called upon to correct this, and, although I was aware that Luke Poland, the Chairman of the Committee, was distinctly antagonistic to me, I went before the Committee for that purpose.

When I entered the room I saw to my amazement that Mr. Brooks, then largely supported by Republicans, had chosen the brother of B. F. Rice, my bitter political enemy, as his counsel, and that Governor Baxter was represented by the chairman of the Democratic State Committee. I also found that $\mathrm{Mr}$. Brooks had made Gen. Dandridge McRae, the red-handed $\mathrm{Ku}$ Klux of White County, who was implicated in the murder of Albert Parker, Brigadier-General upon his staff.

Under those conditions I decided not to testify, and then and there I washed my hands of the whole disgraceful affair, relying for my vindication upon the triumphant termination of my Senatorial investigation.

Without going further into the history of this contest, it is sufficient to say that from the moment Elisha Baxter surrendered the State Government to the Democrats that party became and has remained supreme in the State.

\section{FOOTNOTES FOR CHAPTER XVI}

${ }^{1}$ Arkansas Senate Journal, 1871, pp. I42-16I.

2 Published in Daily Republican, February 21, 1871 .

${ }^{3}$ Arkansas Senate Journal, I87I, p. 282.

${ }^{4}$ Congressional Record, pt. I, 2d Sess., $42 \mathrm{~d}$ Congress, 187I-72, p. 3 II . 
${ }^{5}$ Congressional Record, pt. I, 2d Sess., 42d Congress, I871-72, p. $31 \mathrm{I}$.

${ }^{8}$ Congressional Record, pt. I, 2d Sess., 42d Congress, I87 I-72, p. $31 \mathrm{I}$.

${ }^{7}$ Congressional Record, pt. I, 2d Sess., 42d Congress, I871-72, p. 318.

${ }^{8}$ Congressional Record, pt. I, 2d Sess., 42d Congress, I871-72, p. 318 .

${ }^{9}$ Senate Report No. 512, 3d Sess., 42d Congress, 1872-73, p. 2 .

${ }^{10}$ Congressional Record, pt. 3, 3d Sess., 42d Congress, I87273, p. 1785 .

${ }_{11}$ Congressional Record, pt. 5, 2d Sess., 42d Congress, I87 I72, p. 4498.

12 Senate Report No. 512, 3d Sess., 42d Congress, 1872-73,

p. 4 .

${ }^{13}$ Senate Report No. 512, 3d Sess., 42d Congress, 1872-73,

p. 7 .

p. 8 .

${ }^{14}$ Senate Report No. 512, 3d Sess., 42d Congress, I872-73,

${ }^{15}$ Senate Report No. 512, 3d Sess., 42d Congress, I872-73, p. 9 .

${ }^{16}$ Senate Report No. 512, 3d Sess., 42d Congress, 1872-73, p. 20.

${ }^{17}$ Senate Report No. 512, 3d Sess., 42d Congress, 1872-73, p. 21 .

${ }^{18}$ Congressional Record, pt. 3, 3d Sess., 42d Congress, 187273, p. 2016.

${ }^{19}$ Senate Report No. 512, 3d Sess., 42d Congress, I872-73, p. 19.

${ }^{20}$ Congressional Record, Vol. I, 43d Congress, I873, Special Session of the Senate, p. I 74 .

${ }^{21}$ Congressional Record, Vol. I, 43d Congress, 1873, Special Session of the Senate, p. 192.

${ }^{22}$ Published in Daily Republican, March 16, 1872.

${ }^{23}$ Letter of Hon. D. H. Divilbiss, published in Daily Republican, April 9, I872.

${ }^{24}$ Proceedings of Democratic State Convention, published in Daily Republican, June 21, I872.

${ }^{25}$ Published in Daily Republican, May I6, 1872. 


\section{CHAPTER XVII}

\section{DEMOCRATIC ACCESSION TO POWER AND THE USE MADE OF IT}

The Arkansas Legislature elected in 1872 assembled in January, 1873 , and adjourned in the spring of the same year. Soon after the adjournment Governor Baxter appointed fifty of the members of the two Houses to various offices in the State, all of whom accepted the appointments.

In September, I 873, he issued the proclamation ${ }^{1}$ for special elections to fill the vacancies thus created. Prior to the 4th day of November, I873, when the special elections were held, Governor Baxter ordered a new registration in all the counties where elections were to be held and appointed new boards of registrars to make it. The alleged reason for this was that since the registration made prior to the general election of 1872 the constitution had been amended by striking out the disfranchising clause, and thereby a large number of persons had become entitled to be registered and to vote.

The Republicans did not generally nominate candidates for these special elections, but relied on a public pledge of Governor Baxter's that he would not call a special session of the Legislature. In consequence all, or nearly all, the members so elected were Democrats.

However, Governor Baxter disregarded his public pledge and called the Legislature to assemble in May, I 874. At that time the Capital of the State was divided 
into two military camps and Brooks was in possession of the State House. For this reason the Legislature convened, on the I I th day of May, I 874, within the military lines of Governor Baxter. ${ }^{2}$

When it met there were present only seventeen of the original Representatives elected in 1872 and four of the original members of the Senate. No quorum was had

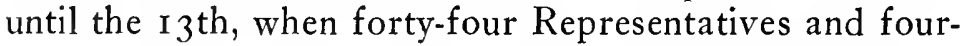
teen Senators were present. On the I6th fifty Representatives were in attendance, twenty-four of the original members and twenty-six who had been chosen at the special elections. Fifteen Senators were present, nine from the original election and six from the special elections. These new members were admitted to seats without objection. ${ }^{3}$

The Act for submitting the question of calling a Constitutional Convention was introduced in this Legislature on the I6th day of May, I874, and was passed by both Houses on the same day. The vote in the Senate was twelve in the affirmative and three in the negative. The whole vote in the House was fifty, but the ayes and nays were not called. ${ }^{4}$

The election was held on the 3oth of June, I 874. The vote, as declared by the State Board of Supervisors, was 80,259 for Convention and 8,607 against; the $\mathrm{Re}$ publicans practically allowed the election to go by default. At the same election delegates to the.Convention were chosen. The Convention met on the I 4 th day of July and proceeded to frame a new State Constitution.

This Constitution should have been submitted to the people under the existing laws, as the Constitutional Convention had no legislative power whatever. Instead of that, the Convention assumed the right of providing the machinery to conduct the election. "There was an existing registration, there were existing officers of registra- 
tion and election, and the Convention had no right to displace them and provide others," as was done. (See Reports of Committees, Nos. IOI to I49, I874-75, pp. I I, I 2.)

Under these conditions the new Constitution was ratified on the I 3 th of October, I 874 , - the vote being 78 ,697 for the Constitution and 24,807 against it. ${ }^{6}$

At the same time the Constitution was voted on, an election was illegally held for all officers provided under it,- State, County, and Township,-and also for members of both branches of the Legislature. The Republicans put up no candidates for State officers. The whole machinery thus put into operation may safely be treated as a political farce.

A. H. Garland was nominated for Governor by the Democrats and was declared elected. On the IIth of November, I 874, the new Legislature assembled, $\mathrm{Mr}$. Garland was inaugurated as Governor, and the State and County officers, chosen in the manner heretofore referred to, entered upon their duties.

When the Democrats thus came into possession of the State Government they, as quickly as possible, undid everything that the Republicans had accomplished.

True to their desire to keep the masses ignorant, the free school system was their starting point. Under Republican rule no matter how much Auditor's warrants, or State scrip, became depreciated, the State officers were compelled to accept payments due them in such funds. Not so with the Democrats! They immediately proceeded to appropriate for the payment of salaries, and for other purposes, the permanent school fund which had been held sacred by the Republicans and kept invested in United States Bonds. The following is a synopsis of a Constitutional ordinance passed for that purpose: The United States currency and United States bonds 
now in the treasury of this State, belonging to the school and other funds of the State, except moneys derived from the proceeds of the sale of lands donated to the State by the United States for school purposes, be and they are hereby borrowed to defray the necessary current expenses of the several departments of this State.

From one of the first acts passed by their Legislature I quote as follows: ${ }^{7}$

"Sec. I. That the treasurer of State is hereby authorized and required to contract with the State Board of Finance for the sale of all United States securities now in his custody belonging to any permanent fund of this State and of all United States currency in the treasury.

"Sec. 2. That the said sale shall be made for bonds of this State, authorized to be issued by act of the General Assembly, approved December 23, I 874, at the minimum price of said bonds as fixed by law.

"Sec. 3. That when said sale shall have been made the said Board shall make requisition on the said treasurer of State for the amount of bonds so contracted for, and said bonds, after being signed and attested as required by him, shall be deposited in the treasury in lieu of said United States securities, and in all respects to be used and take the place of the same."

In the year 1876 , under the provisions of this act, the United States bonds then constituting the permanent school fund were converted, by the Board of Finance, into Arkansas State bonds bearing interest at the rate of 6 per cent. ${ }^{8}$ At that time Arkansas State bonds could not be sold at any price in any of the markets of the world.

Under the Republican law the interest on the school bonds so purchased was required to be apportioned among the various school districts for the support of common 
schools, but now comes the saddest tale of all. For the year 1874 the State defaulted on the interest on these bonds and remained in default until May 8, I 899, a period of twenty-six years, when an act was passed ${ }^{9}$ requiring these Arkansas 6 per cent bonds to be re-issued, with accrued interest thereon amounting to $\$ 5$ I 2,335.00, ${ }^{10}$ in Arkansas 3 per cent bonds. Any sensible person must know that if there were no purchasers for Arkansas 6 per cent bonds, there would surely be none for Arkansas 3 per cent bonds.

This scheme converted a permanent school fund, invested in securities bearing a premium, into 3 per cent State bonds not worth the paper they were printed on, and the money obtained thereby was applied, among other things, to the payment of the salaries of State officers. The effect of this beating around the bush was to eliminate the permanent school fund and place the whole burden of maintaining the public schools upon the shoulders of the taxpayers of Arkansas.

But that was not all. The public schools were closed for the years 1874 and 1875 under the pretext that the Brooks-Baxter "war" had plunged the State into a condition of anarchy and that the opening of the schools was impracticable. The children of the State were deprived of two years of education on account of this contest, which was ridiculously called a war. Only one man was wounded throughout the entire controversy, and that was an accident. This unwarranted closing of the public schools only showed the incompetency of Governor Baxter, who was, to say the least, the Governor de facto during that period.

In the report of State Superintendent of Public Instruction, George B. Cook, for I9 I 2, he used the following language: ${ }^{11}$ "The permanent school fund is safely invested in State bonds bearing 3 per cent interest." If 


\section{THE AFTERMATH OF THE}

by "safely invested" Superintendent Cook meant that they were safe from the pilfering of any thief who might break into the State Treasury, he was correct, for no such culprit would ever stop to pick up such a bond any more than he would a Confederate bond that he might find lying in the Treasury, as both were of no value.

I venture to say that never in the history of any State have more dishonest methods been resorted to. Could the masses of Arkansas, through the density of their ignorance, discern the truth and have a lawful opportunity to make effective their will, no Government so conducted could, in my opinion, survive the first test at the polls.

The next Republican policy attacked by the Democrats was the loaning of State Aid to Railroads. On April Io, I $869,{ }^{12}$ a law was passed by the Republicans providing for the payment of the interest by the railroad companies on the State bonds loaned to them. The railroad companies were perfectly satisfied with this law and were not asking for any relief. Nevertheless, this law was immediately repealed ${ }^{13}$ by the Democrats upon their accession to power, and the railroad corporations were thereby relieved of their just and acknowledged liabilities.

The taxpayers of Arkansas were not required by the State Aid Law to pay one cent of interest or principal on account of the State Aid bonds. Under the strict provisions of the law the Railroad Companies and not the people were required to do so. ${ }^{14}$ While I was Governor every railroad company receiving State Aid fully acknowledged this liability.

It is a matter of record in the United States Court at Little Rock that in the suit of W. S. Pierson, Watson Matthews, and R. K. Dow vs. The Memphis and Little Rock Railroad Company, Sam Tate, et al., that company had bought up 93 I bonds of \$I,000 each, "which bonds were issued to the Memphis and Little Rock Railroad 
Company; fifty-eight ( 58 ) to the Arkansas Central Railroad Company; thirty-two (32) to the Mississippi, Ouachita, and Red River Railroad Company; and nine (9) to the Little Rock and Ft. Smith Railroad Company'. And also five hundred and one (5OI) detached coupons from 'State Aid Bonds.' The character and number of said 'State Aid Bonds' and coupons are shown upon Exhibit ' $\mathrm{H}$ ' hereto. Which last named bonds and coupons your Master holds subject to the order of the Court, and asks that he may make some disposition of the same or be otherwise relieved from responsibility for their custody.

$$
\text { "Chas. P. REDMond, Master." }
$$

These bonds were undoubtedly purchased for the liquidation of an equivalent part of the State Aid debt contracted by that company. In the Pulaski Chancery Court it is also a matter of record in the suit of W. B. Worthen vs. The Little Rock and Ft. Smith Railway Company that this company had bought up $\$ 627,000$ of these bonds, inclusive of all overdue coupons, for the purpose of liquidating its indebtedness to the State in a corresponding amount, leaving only $\$ 373,000$ of its original State bonded indebtedness to be provided for.

Other companies were preparing to do the same thing, but when the Democratic party came into power in Arkansas they repealed that portion of the law providing for the payment of interest on the bonds.

This repeal was passed before the courts had denied the validity of the Railroad Loan Act; therefore, unless the members of the Legislature who voted for the repeal knew beforehand that the courts would invalidate that act, they deliberately relieved these corporations of their just liabilities and compelled the bondholders to look to the State for their money.

By a technicality never dreamed of by anyone during. the years the railroad companies were receiving and sell- 
ing bonds, the Act was declared unconstitutional. The alleged flaw was that upon the passage of the Railroad State Aid Bill the aye and nay vote was not made a matter of record, as required by the Constitution!

As it was with the Funding Bonds so was it with the State Aid Bonds. None of them were owned by citizens of the State. They had been sold to Northern and European purchasers, and no one in Arkansas was concerned in their behalf. I consider it a very bad policy for a State to issue bonds for any purpose when none of them are owned by its citizens.

But worse things than these were to follow. Their methods now became wholesale. In the year i $879 \mathrm{~W}$. M. Fishback, the Democratic convert, introduced a joint resolution in the Arkansas Legislature providing for an amendment to the State Constitution, which should prohibit the making of any appropriation to pay either principal or interest of the Funding, or "Holford," bonds, the bonds issued to aid in the construction of railroads, and those known as the levee bonds.

This joint resolution was passed by the General Assembly, and the adoption of the Amendment was submitted to the people at the general election held in September, 1880. Among the prominent men who took a stand against it was A. H. Garland, who fought it, as he declared, "inch by inch, foot by foot, step by step." In a great speech made by him at Russellville on July I 2, I 880 , in a debate with W. M. Fishback, the author of the amendment, he used the following language: ${ }^{15}$

"If these bonds are ignored, repudiated, destroyed, yet still the debt remains to haunt the courts and the State. If these bonds are rejected, you will still have to meet the question at last,- -where is the debt which these bonds represent?-and, until the paper is drawn in and receipts 
passed, there is no settlement before God or man or before gentlemen-and the State cannot afford to be anything else but a gentleman before the world.

"I think this Amendment is conceived in a mistaken policy. I think its advocates and friends have gravely erred in propounding it to the people of Arkansas and urging it upon them for adoption. If they were the sworn enemies of the State, armed with a sword in one hand and a torch in the other, determined to do the State the utmost damage, they could not, in my opinion, more completely accomplish their end than by having the proposed Amendment incorporated in the Constitution. . . . The adoption of the Amendment would, in my opinion, be the memorial blunder, if not the crowning crime, of the age."

This was from an ex-Governor of their own party, and even the Gazette, the Democratic organ, took ground against the adoption of the Amendment. When it went to vote it was defeated.

But the Democrats were not content with this expression of disapproval by the people, and efforts for the adoption of the Amendment were renewed by Mr. Fishback in the Legislature of I 883. Through his influence it was passed again by that body ${ }^{16}$ and re-submitted to the people in I 884 , when it was ratified, and it thereafter became a part of the State Constitution. ${ }^{17}$ It had by this time become generally known that the hated New England "Yankee" owned the bonds sold by the State, and that fact alone was a sufficient reason with the ignorant population of the State for their repudiation.

By this act they succeeded in nullifying all the efforts made by my administration to restore the credit of the State. Innocent purchasers were robbed,-people of moderate means who, relying upon the honor of a great 
State, had invested their earnings in its securities,-and Arkansas was placed forever among the black-listed States in the markets of the world.

This is a strong and sweeping statement, yet the history of the State from its admission into the Union in I 836 down to the present time, exclusive of the period of Republican administration, fully justifies the charge of procuring loans for the benefit of its individual citizens and afterward relieving them of their just liabilities by repudiation.

Henceforth the name of William M. Fishback will always be connected with this most disgraceful and unAmerican act, -an act that cast over the annals of the State a blot so dark that all the water of the two oceans could never wash it away.

$\mathrm{Up}$ to this time I have dealt with the actions of the Democrats as a party. I shall now make mention of several individuals that occupied high places under the Democratic Government.

Among the officers elected by the Democrats under the new State Constitution was ex-Confederate Maj.-Gen. T. J. Churchill, Treasurer. He was elected for three successive terms covering from I 874 to January I 2 , I 88 I, and his six years of service as Treasurer were followed by his election in I $88 \mathrm{I}$ to the office of Governor.

Soon thereafter, in spite of all efforts at concealment, it leaked out that large defalcations existed in General Churchill's accounts as Treasurer. This matter was taken up by the Legislature of $\mathrm{r} 88 \mathrm{I}$ and resulted in the appointment of a Senate Investigating Committee. This Committee made a partial report toward the close of that session, ${ }^{18}$ but no definite action was taken until January 20 and $22, I 883$, when a joint committee was raised $\mathbf{1 9}$ to investigate the accounts of Treasurer Churchill. After an examination of the books kept during his 
first term as Treasurer the joint committee, on February 26, I 883 , made a report to the Legislature setting forth in detail the deficit for this term, amounting to \$294,876.37 , which report was adopted. ${ }^{20}$

On the I6th of March, I883, the joint committee made its report to the Legislature on its investigation of the books kept by General Churchill during his second term of office, which showed a net balance to his credit of $\$ 86,097.05$. This report was also adopted. ${ }^{21}$

On the 24th of March, I883, the joint committee made its final report to the Legislature showing in detail the shortage existing in General Churchill's accounts for his third and last term as Treasurer, which amounted to $\$ 24,837.57$.

This report set forth that his entire defalcation amounted to the appalling sum of $\$ 233,6 \mathrm{I} 6.89$, and it was adopted by both Houses of the Legislature. In addition to this amount it was also shown that there was a deficit in the permanent school fund amounting to $\$ 50$,$237.23 .{ }^{22}$

Two days thereafter, on March 26, I 883, a concurrent resolution was introduced in the House by Mr. Barker, directing Gov. T. J. Churchill to cause suit to be brought against the recent Treasurer T. J. Churchillhimself,-on his official bond for the recovery of the missing school fund, which was read and adopted. ${ }^{23}$ It was then sent to the Senate, where the resolution was lost.

So far as the Legislative proceedings and court records show, no decision was made as to the burning of the scrip belonging to the permanent school fund, which General Churchill admitted was burned by him through mistake.

The law providing for the Burning Board was passed by the Democrats on May 28, I874, and reads as follows: ${ }^{24}$ 
"The governor, secretary of state, and auditor shall be, and they are hereby, constituted a board for the purpose of examining cancelled scrip, treasurer's certificates, warrants, and other securities that may now be in the State treasury, or that may hereafter be received and borne on the accounts of the auditor and treasurer as funds on hand or balances, with authority to count and destroy the same by burning or otherwise.

"Whenever such funds or securities shall accumulate in the treasury in sufficient quantity to make it necessary or advisable to have the same destroyed, the treasurer shall prepare a statement thereof and submit the same to the governor, who shall thereupon assemble said board for the purpose of examining the funds scheduled or stated for examination; and if said board shall find, upon a careful and particular count and investigation, that such funds are correctly stated and agree in every particular with the schedules thereof, said board shall so certify and shall thereupon immediately destroy such funds or cause the same to be done in their presence; and the certificate of said board shall be sufficient authority for the auditor to credit the treasurer's account with the amount of funds so destroyed."

It will be seen at once that this act could be used to cover any amount of corruption, and it was so used. It was disclosed in testimony taken by the joint committee that the scrip to be burned was put up in packages and scheduled at the will of the Treasurer, and he received credit for the amount shown to be burned by the schedule prepared by himself.

This law opened the door for the perpetration of the grossest frauds against the State and left no check whatever on the Treasurer. There was absolutely nothing to prevent him from giving out to be counted over and over 
the same identical packages of scrip, taking credit on his accounts each time, as once a package had been scheduled for burning by the Treasurer it was not investigated by any other officer and was burned by clerks without having been opened. Therefore any amount of scrip could have been extracted from each package by the Treasurer, and that fact remain undiscovered. This defaulting officer, Churchill, so completely covered his fraud by his manipulation of the Burning Board that at the expiration of his third term as Treasurer his defalcation was not disclosed and he was elected to the position of Governor of the State.

After the first report of the joint committee was made to the Legislature, while the defaulter Churchill was Governor, as before stated, a concurrent resolution was introduced in the House directing the Governor to bring suit against himself for the deficit shown to exist by the investigations of the joint committee. This resolution was adopted by both Houses; the vote in the Senate was 22 to o, and it was 79 to 0 in the House. ${ }^{25}$

Thus we have the unique situation of a Governor of the State being directed by an act of the Legislature to have suit instituted against himself. Under this resolution suit was brought by the Attorney-General on May 30, I883, in the Pulaski Chancery Court against T. J. Churchill, Governor of Arkansas, and his bondsmen, for the amount of his defalcation while Treasurer of the State.

A decree was rendered therein on the IIth day of February, r 884. On the roth of March, r884, Thomas H. Simms was appointed Special Master by order of the court, to state the accounts in the cause. On June 20, I 884 , he reported ${ }^{26}$ that his investigations showed that General Churchill's defalcation amounted to $\$ 80,522.0$ r, 
for which sum a judgment was rendered against the Democratic Governor of Arkansas.

The report of Mr. Simms does not show that any action was taken to replace the scrip belonging to the permanent school fund, which was burned by mistake.

I shall now give an illustration of the difference between Democratic and Republican methods:

Col. Henry Page was State Treasurer during the entire time the Republicans were in power in Arkansas. When he resigned on May 20, I874, his accounts were checked and vouchers to the amount of $\$ 2,788.46$ were missing. Although Colonel Page felt certain that they would be found, knowing, as he did, his absolute freedom from fraud, yet, to protect his bondsmen from loss, he deposited that amount of money with the fiscal agent of the State, the Union Trust Company of New York, and received from the auditor a certificate of non-indebtedness to the State.

Years passed, and when the large defalcations of Treasurer Churchill came to light, as above detailed, and the joint committee was appointed to investigate his accounts, it was deemed advisable by them to examine the closed accounts of his predecessor, Colonel Page. In making this examination all the old cancelled bonds were removed from the treasury vault for checking, and the envelope containing Treasurer Page's missing vouchers was found on the shelf underneath the bonds, where it had remained for years. This information was conveyed to Colonel Page by Mr. Woodruff, who was then Treasurer of the State.

This envelope contained warrants corresponding exactly to the amount Colonel Page had deposited with the fiscal agent of the State-\$2,788.46-but the State has persistently failed to refund Colonel Page's money, and that amount is still due him. 
The name of Col. Henry Page, as an honest and faithful public official, is held in high esteem by the Republicans of Arkansas, and will go down into history as the Treasurer of the State who came out of office with an absolutely clean record.

Maj. John Crawford was State Auditor and a member of the Burning Board during the greater part of the time General Churchill was Treasurer, his term of service having been from January, I 877 , to January, I 883 . During the investigation of the accounts of Treasurer Churchill it was found that a shortage also existed in the accounts of Auditor Crawford. A suit was instituted against him in the Pulaski Chancery Court and a judgment was rendered for the sum of $\$ 9,922.09$.

This is the same Major Crawford whom the militia pulled out of the loft of a Ku Klux den at Centre Point by his heels, as described on page I I3.

After the accession of the Democrats to power in Arkansas they attacked and destroyed every measure that had been advocated or accomplished by the Republicans. They repudiated the bonded indebtedness of the State, which had been so solemnly approved by the people at the polls, and placed in positions of trust men who were guilty of the grossest frauds against the State Treasury.

It may be asked why a party guilty of such abuses as I have exposed should have been permitted by the people of a State to remain in power continuously since 1874 . I answer with the adage: "Possession is nine points of the law." The election machinery through which they would have to be deposed has been in their hands, and they have not hesitated to use it. Their election law is an infamous measure providing for a State Board of three members, and the Republicans have never been allowed any representation thereon.

I remember one instance when the three officers who 
composed this State Board of Election Commissioners were candidates for re-election, and they counted the votes for themselves; and at each election at least one member of the Board was also a candidate for re-election to a State office.

In addition to their complete control and manipulation of the election machinery, as each biennial election drew near in Arkansas some new version of the evils of the Reconstruction period was brought forth to distract the attention of the voters from the misdeeds of the Democratic Party ring, and make it possible for them to avoid giving an account of their stewardship. The wildest and most fallacious stories have been told by them. That the reader may understand the nature of their perversions, I will give the following illustration:

While I was serving my country as Ambassador to Mexico, Jefferson Davis, who was a candidate for reelection to the Governorship of Arkansas, announced, without explanation or specification, from the stump to large audiences that I had murdered his aunt. This was gulped down with great relish by his ignorant followers. Later, to keep himself solid with them, he refused to attend a banquet given at Little Rock by the Board of Trade in honor of President Roosevelt, where by virtue of my position I was seated at the Presidential table. In explanation of his gross lack of courtesy to the President he told him that I had murdered his aunt and that he could not sit down to a table where I was a guest.

Soon after the banquet I called on President Roosevelt in Washington. He remarked to me in a facetious manner, "Governor Davis says you murdered his aunt; why didn't you murder his uncle?"

While I was fully aware of the falseness of this accusation, I realized that unless it were absolutely proved to be false there were those who would believe it. 
Mr. Guy Caron, then the editor of the Republican, kindly offered his services and went to the scene of the alleged murder to investigate fully all the circumstances. From his detailed report, published in the Republican on August I7, 1906, I quote as follows:

"Sitting in the very house where she [the aunt of Jefferson Davis] died, in conversation with the physician who attended her last illness, who was also her husband's business partner, this physician, who is still practicing his profession in that county, although speaking reluctantly, admitted to me that there was no foundation to the story of murder, and that no such accusation was ever made until very late years, and that he gave it no credence whatever. This man is a Democrat and wishes neither to embroil himself nor to hurt his party by discussing this question, but he could not in fairness refuse to tell me the truth that Mrs. Hamilton was in good health when the militia left Richmond, and that her death was unexpected both to himself and her husband, who was also a physician.

" 'For some unknown cause puerperal fever set in, to the surprise of both myself and Dr. Hamilton, which resulted very quickly in her death.' Neither of them at that time thought of attributing her death to the presence of the militia, and Dr. Hamilton was never heard to make that charge.

"I talked with every other citizen I could find who in I 869 was a resident of Richmond and found that without exception they corroborate the above statements. These old men, who have no selfish interests to pursue, and care only for their honor and the truth, all join in asserting that Mrs. Hamilton died from causes entirely removed from the presence of troops, and that no one accused the 
soldiery at the time of the occurrence, when there was the most reason for bitter feeling and partisanship. ..."

A copy of this statement was sent to Governor Davis. Thereafter nothing was heard from him concerning this monstrous fabrication.

This serves as a conspicuous example of the extent to which Reconstruction perversions were used by the Democrats to divert the attention of the voters from the defalcations and maladministration of their public officials. In every campaign I requested our speakers to devote their time to an exposure of the official misdeeds of the Democrats instead of falling into the trap of defending me against their vicious attacks.

But since their advent to power the corrupt malfeasance of the Democratic party has continued.

It is plain that the basic principle of good government, which depends on two parties, the "outs" watching the "ins," is completely destroyed, and that nobody but the members of the Democratic ring of office-holders in Arkansas know what is officially going on.

If for six years Treasurer Churchill could have piled up such an immense defalcation without detection, what can be expected under the more ironclad opportunities which exist there now for official corruption?

\section{FOOTNOTES FOR CHAPTER XVII}

${ }^{1}$ Reports of Committees, Nos. I to I00, I874-75, Report No. 2, pp. 223-7.

${ }^{2}$ Reports of Committees, Nos. IOI to I49, I874-75, Report No. 127 , p. 9.

${ }^{3}$ Reports of Committees, Nos. IOI to 149, I874-75, Report No. 127 , p. 9.

${ }^{4}$ Reports of Committees, Nos. IOI to $149,1874-75$, Report No. 127, p. 10. 


\section{CIVIL WAR, IN ARKANSAS}

${ }^{5}$ Reports of Committees, Nos. Ior to $149,1874-75$, Report No. I27, p. II.

${ }^{8}$ Reports of Committees, Nos. IOI to I49, I874-75, Report No. 127 , p. 12.

${ }^{7}$ Arkansas Laws, 1874-75, p. 162.

${ }^{8}$ Report of State Auditor, Arkansas, 1875-76.

${ }^{9}$ Report of State Superintendent of Public Instruction, Arkansas, 1899-1900, p. 28.

${ }^{10}$ Report of State Superintendent of Public Instruction, Arkansas, I 897-98, pp. 2 I I-I 2-1 3 .

${ }^{11}$ 22d Biennial Report of State Superintendent of Public Instruction, Arkansas, I91 1-1 2, p. 5.

12 Arkansas Laws, I 868-69, pp. I 47-1 50.

${ }^{13}$ Arkansas Laws, Special Session, May, 1874, p. 38.

${ }^{14}$ Arkansas Laws, 1868, p. 151, Sec. 7.

${ }^{15}$ Hempstead's "History of Arkansas," pp. 281-2.

${ }^{16}$ Arkansas Senate Journal, I883, pp. 99-100; Arkansas House Journal, I883, pp. 16r-2.

${ }^{17}$ Arkansas Senate Journal, I 885, p. 53.

${ }^{18}$ Arkansas Senate Journal, I881, pp. 420-42 I.

${ }^{19}$ Arkansas House Journal, I883, p. 141 ; Arkansas Senate Journal, I883, p. 132 .

${ }^{20}$ Arkansas House Journal, 1883, pp. 573-586.

${ }^{21}$ Arkansas House Journal, I883, pp. 821-828.

${ }^{22}$ Arkansas House Journal, I 883, pp. 964-976.

${ }^{23}$ Arkansas House Journal, 1883, p. 993.

${ }^{24}$ Arkansas Digest of Statutes, Mansfield, I 884. Sec. 3207-8, pp. 674-5.

${ }^{25}$ Arkansas House Journal, I883, pp. 588-9; Arkansas Senate Journal, r883, pp. 544-5. 



\section{INDEX}

Act to aid in the Construction of Railroads, $244,245,246,320,358$.

Act to Provide for the Funding of the Public Debt of the State, 258, 260, $271,273,274$.

Adams, E. W., I56.

Adams, General, 83.

Adams, Governor, 252.

Alabama, 216, 257, 299, 301, 303.

America, 53, I 70, 214 .

American Citizen, 46, 87, 169.

American Exchange National Bank, 258, $27 \mathrm{I}$ :

American People, I49, 286.

American Union, 17, 35, 166.

Anderson, Captain, 122.

Andrews, Maj. P. J., 69, 99, 100, 101, I02, II 4 .

Ante-bellum, I3, 31, 239.

Anthony, J. J., 15, 16.

Arkadelphia, Ark., 22, 48.

Arkansas, 13, 16, 17, 18, 19, $21,23,24$, $25,26,27,29,30,3 \mathrm{I}, 32,34,35,4 \mathrm{I}$, $42,46,50,54,56,57,59,60,61,62$, $63,65,66,88,91,92,95,96,98$, 100, 102, 105, I 109, I10, I I 5, I3 1 I 138, I61, 162, 166, 178, 181, 183, 192, 195, 197, $204,207,208,209,210,213,215,217$ $218,224,230,231,233,234,235,240$, $244,245,246,251,254,256,258,263$, $268,270,273,273,276,278,282,283$, $284,285,286,290,298,299,300,301$, $302,303,304,305,306,307,308,313$, $3 \times 5,321,331,333,334,335,337,338$, $343,344,345,346,354,355,359,360$, $364,365,366,368$.

Arkansas Central Railroad, 357.

Arkansas County, 67.

Arkansas Industrial University, 233, 235.

Arkansas River, 18, 204, 215, 216, 248, 296, 30r.

Arkansas Valley, 21, 21 3, 215.

Armstead, Enoch, 187 .

Armstrong, Carroll, I9I.

Ashley County, 63, 67, 69, 90 .

Assassination, 51, 61, 64, 68, 70, 73, 88, $89,90,9 \mathrm{I}, 92,93,95,96,97,99$, I02, I $38,141,142,143,165,177,178$, I86, I87, I 89, 190, 269.

Auditor's Warrants, 231, 232, 297, 353.

Augusta, Ark., I 19, I 20, I 2 1, I 22, 123. I 24, I25, I28, I30, I32.

Augusta Șentinel, $124,217$.

Ayres, Brig.-Gen. R. B., 130, 133.
Babcock, General, ז 30 .

Baker, Cullen, III, II4, II 5 .

Baker Gang, 99, roo.

Ball, Jordan A., 70.

Barker, Hon. E. G., 70, 89, 90, 128, 135, I $36,137$.

Barton, J. McL., 302.

Batesville, Ark., 18, 22, 83, 120.

Battle, B. B., 320.

Baxter, Hon. Elisha, 29, 284, 346, 347, $348,349,351,352,355$.

Beaumont, Col. S. B., r39, 140.

Bellows, J. T., I80, I8I.

Benjamin, M. W., 3оI.

Bentley, George, '150, I5 I, 162, 163 .

Bentley, Ollie, 188, 189, 190.

Benton County, 36, 66, 214 .

Berry, Capt. Charles E., 263, 264.

Berry, Hon. J. R., 257, $270,299$.

Bethel, George J., 178, 182.

Bethel, R. C., I78.

Biscoe, Cameron N., 95, 96.

Bishon, Adj.-Gen. A. W., I8, 233.

Bliss, C. C., 28.

Boles, Hon. Thomas, 329, 335.

Boston, Mass., 208, 209, 289.

Bowdrie, A. R., 188.

Bowen, Hon. Thomas M., 244, 245, 247, $300,337$.

Bradley, Dr. A. R., 189.

Bradley County, $63,67,249$.

Bradley, Howell, 88.

Brayman, Gen. M., 44, 24I, 242.

Breckinridge, Clifton R., I 54, I84, I86, I87, I90, I9I, I92, 193.

Breeden, Pompey O., I62.

Brian, Capt. W. M., I23, 125.

Brinkley, R. C., 240 .

Brooks-Baxter War, 349, 355.

Brooks, Hon. Joseph, 70, 86, 96, 97, 98, $99,315,329,344,346,347,348,349$, 352.

Brown, Gov. Gratz, 315.

Brundidge, William, $76,78,80,8 \mathrm{r}, 82$, 88.

Bryant, Captain, $9 \mathrm{r}$.

Buford, Federal Brig.-Gen., I 9.

Burks, Capt. H. C., I 7 , I 18.

Burning Board, 361, 362, 363, 365.

Burrow, LeRoy. $76,77,78,80,81,82$, $84,85,86,88$.

Burrow, Rankin \& Co., 152, 153.

Bush, B. F., 294.

Butler, Hon. James A., 73, 74, 
Cairo and Fulton Railroad, 44, 238, 240, 24 I.

Caldwell, Hon. Henry C., 202, 203.

Calhoun County, 66, 320 .

California, I9I, I92, I97, 2 I3.

Camden, Ark., 60, 248 .

Cameron, Senator, 340.

Canada, 86, 303.

Capitol, State, 14, 103, I 6.

Carpet-bag, 266, 285, 290, 298.

Carpet-bagger, 209, 267, 269, 298, 303, $304,305,308$.

Carroll County, 66.

Casey, James M., I54, I55, 156, I6I, I62.

Cate, Judge, I $84,185$.

Catterson, Brig.-Gen. R. F., 66, III,

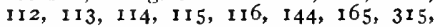
343.

Centre Point, Ark., I I I, I I 2, I I3, I I4, I 32, 365.

Chicot, Ark., 294, 295.

Chicot County, Ark., 67.

Chinese laborers, 208, 2 I 2, 2 I3, 2 I 4.

Chrisman, Maj. F. M., 74, 75, 81, 300.

Churchill, Gen. T. J., 270, 360, 36I, $363,364,365,368$.

Circuit or district superintendents, 47, $74,222,225,226,229,230,231,232$, 300.

Civil law, 87, 121, 124, 126, 131, 1 33, 137 , I64.

Civil War, I7, 23, 39, 58, 91, 95, 109, I I I, $126,129,131,132,147,148,158$, $159,167,168$, I $71,172,177,207,223$, $239,282,283,284,299,300,301,302$, $304,305,306,347$.

Clarendon, Ark., 97, I 38.

Clark County, 22, 23, 66, 319.

Clark, George W., 97, 99.

Clark, Sol F., 85, 87 .

Clarksville, Árk., 200, 215.

Clayton, John M., I 54, I 84, I 86, I87, 189, I90, I9 I, I 92, 249, 250, 3 10.

Clayton, Gov. Powell, 49, 65, 74, 97, I I, I I I, I 23,139 , I $75,184,202,215$, $234,241,246,258,259,260,261,262$, $263,265,267,269,271,272,273,275$, $279,298,319,320,321,322,323,324$, $325,326,327,334,335,336,338,339$, $340,341,345$.

Clayton, Judge Thomas J., 249, 250.

Clayton, Judge W. H. H., I 42, 143, 299, 306.

Clendenin, Judge J. J., I 72.

Collier, Clarence, 175, 177, 178, 179, I 80, I 81, I 82 .

Columbia County, 63, 66, 69, 320.

Commander-in-chief, $41,65,67,107$, 165 .

Common School Fund, 46, 222, $224,229$.

Confederacy, I 8, 22, 29, 59, I 72, 282 .

Confederate Army, 18, $61,62,78,85$, $89,167,300,302$.

Confederate soldiers, 6o, I09, 167, I73.

Confederates, I $7,35,172,347$.

Congress, United States, 25, 27, 28, 30, 31, 32, 70, 96, 97, 106, 107, 125, $166,170,171,185,187,221,233,234$,
$235,273,290,310,329,330,331,335$, $337,339,342,343$.

Congressional Investigating Committee, I 84,189, I 9 I, I 92.

Conley, W. L., I 59, 160.

Conscription, Confederate, I8, I I 0, 283.

Constitution, State, I 7, 21, 28, 34, 41, $44,46,50,51,53,67,148,196,225$, $237,255,261,262,306,3$ I $2,313,316$, 317,3 I, 3 I $9,320,35$ I, 352, 353, 358, 359,360 .

Constitution, United States, 64, I69, I 70.

Constitutional amendment, 250, 313, 3 I 5,3 I 7,3 I $8,358,359$.

Constitutional Convention, State, 19, 20, $21,22,23,24,25,27,28,55,172$, $285,289,316,352,353$.

Conway County, 66, 70, I 44, I 49, I 50, I 5 I, I 53, I 54, I 55, I 56, I 57, I 60 , I 6 I, $162,163,175,186,187,188$, I 90 , I 91 .

Conway, Governor, 254, 256.

Cook, George B., 355, 356.

Cotton, Lieutenant, I I 2 .

County seats, 19, 205, 292.

Craighead County, 63, 66, 70, I I9, I24, I $30,201$.

Crawford County, I 8, 66.

Crawford, Maj. John, II2, $270,365$.

Crittenden County, 66, 70, 90, 126, 1 27 , I 28 , I 29, I $30,134,135,136,137$, I 39 , I 40, 163, 175, I76, I 77, 181, 1 82, I 83, I 84,185 .

Cross County, 66.

Crump, B. C., I 4 I.

Crutchfield, S. M., 123.

Dallas County, 66.

Danforth, Adj.-Gen. Keyes, 58, 62, 67, 75,76 , I I 9 , I 2 I, 205,29 I.

Davis, Gov. Jefferson, $366,367,368$.

Defalcations, 270, 360, 361, 363, 364, 368.

Demby, Col. J. H., I I I, I I 2 , I 8 .

Democracy, 86, 98, 195, 229, 24I, 265, $281,295,309,332$.

Democratic, 30, 31, 34, 61, 83, 86, 89, 9 I, I 45, I 51 , I 83,187 , I 9 I, 192, I 96,201 , $207,209,213,217,268,269,279,282$, $285,287,304,3 \mathrm{r} 6,33 \mathrm{I}, 333,339,35 \mathrm{I}$, 364 .

Democratic counties, 304,305 .

Democratic government, 232,360 .

Democratic leaders, $96,166,261$.

Democratic National Convention, I7, 35, 166,344 .

Democratic Party, I7, 34, 35, 5I, 58, 88, $96,98,143,166,190,231,239,281$, $285,306,315,344,347,348,357,366$, 368 .

Democratic press or papers, 90, 197, 202.

Democrats, 17, 29, 52, 53, 82, 85, 86, $93,97,127$, I 52,184, I 95, I 96,200 , $223,233,239,240,269,280,297,306$, 309,3 I0, 3 I4, 3 I $5,324,335,343,346$, $347,349,35 \mathrm{I}, 353,356,359,360,36 \mathrm{I}$, 365,368 .

Desha County, 66,67 . 
DeVall's Bluff, Ark., 18, 84, 90, 1 I9.

Disfranchise, 50, $51,96,269$.

Disfranchisement, $51,59,313,316,317$, $35 \mathrm{I}$.

District of Arkansas, 34, I00, I72, 202, 290.

Dorsey, Senator, 342.

Dowell, Gilbert, I77, I 80 .

Drew County, $21,67,70,116,118,241$, 320.

Drew, Governor, 253.

Duke, S. A., 1 i 8.

Eagan, Colonel, I 55, I 60.

Eagle, Governor, 190, 191, 192, I93, 278 .

Earle, Maj. J. F., I4I.

Education, $45,46,47,220,223,224$, $225,226,230,231,232,235,355$.

Educational interests, 45, 46, 47, 224, $225,226$.

Edwards, Captain, 70.

Edwards, John, 329, 330, 331, 333, 334, $335,339$.

Edwards, William L., 76, 80, 82.

Eldorado, Ark., 60, $20 \mathrm{I}$.

Election, 25, 28, 30, 31, 37, 41, 44, 5I, $52,53,58,71,85,86$, I $48,184,187$, I $88,189,232,237,265,267,268,329$, $330,33 \mathrm{I}, 335,339,347,348,35 \mathrm{I}, 352$, $353,358,366$.

Election frauds, 330,343 .

Election Law, 4I, 365 .

Elective franchise, 4I, 3I2, 3I3, 3I6.

Electors, 40, 4I, 54, I48, 269, 3 I 2.

Emancipation, 21, 169, I 7 I.

English, Judge, 300.

Eureka Springs, Ark., 249, 27 I.

Ex-Confederate soldiers, 31,50, II I 72.

Executive, 48, 49, 64, 67, 106, 107, I64, $251,254,255,266,267,291,339$.

Executive chair, $231,267,269,270,315$, 3 I 6.

Executive office, 15, 102, 124, 243, 261, 266.

Fagan, Gen. James J., 83, $142,143$.

Faulkner, Col. Sandy, 144 .

Fayetteville, Ark., 18, 22, 233, 235.

Featherstone, Colonel, 185.

Federal Army, I 3, 78, I I o, I 59, 300, $306,347$.

Federal officers, 343, 345.

Federal troops, 22, $23,203$.

Federal Union, 46, 224.

Fiscal agent of state, 258, 259, 27I, 364 .

Fishback. William M., 19, 25, 29, 282, $283,284,285,287,289,292,293,294$, $296,298,304,305,306,307,358,360$.

Fitzpatrick, C. B., 302 .

Flanigan, Gov. H., I 72 .

Forrest, Gen. N. B., 58, 59, 6o, 83, 136.

Fort Smith, Ark., 18, 19, 129.

Franklin County, 66,263 .

Freedmen's Bureau,' 91, I00, I02, 135, I 37, 229.
Frolick, Col. Jacob, 76, 77, 78, 79, 80, $82,83,85,86,87$.

Fulton County, 5I, 66, 70, 90, 91, 121 . Fulton, E. A., 24I, 242, 320 .

Funding, 251, 257, 261, 270, 274, 276, $277,280$.

Funding bonds, 234, 276, 279, 280, 359 .

Gantt, Gen. E. W., 76, 302 .

Garland, Hon. A. H., I44, I 49, 353, 358.

Gauze, Hon. C. L., I 24 , I 25.

Gazette, or Democratic organ, 51, 53, $54,59,88,90,91,92,93,94,95,96$, I I $4,149,150,152$, I 54 , I 55, I 56,157 , $160,163,167,182,196,197,207,208$, $213,214,215,216,217,218,229,238$, $240,241,242,259,260,261,264,278$, $287,295,302,303,304,307,308,309$, $312,314,359$.

General Assembly, Arkansas, 38, 46, $54,67,106,144,163,221,224,244$, $251,255,257,302,304,313,317,319$, $320,326,339,354,358$.

General government, $29,35,36,44,65$, $106,143,221,233,237,316$.

Georgia, 216,303 .

Gibbons, Capt. John J., I 54, I 55, 157 , I 58 , I $59,161,163$.

Gillam, Rev. W. H., 300.

Gordan, Anderson, $153,156,161$.

Gordan, James M., I 56, 159.

Gordan, Lydia A., 156, 160, I61.

Gouge, William M., 256.

Government, United States, 32, 68, 88, 1 6 , 109, I 32, 137, 169, 274, 278 .

Governor, of Arkansas, 14, 28, 31,37 , $57,64,81,108,119,123,124,128$, $129,140,141,142,143,163,202,203$, $204,242,243,246,256,257,258,261$, $262,266,267,268,269,273,276,280$, $285,290,291,292,298,3$ I $9,320,321$, $322,323,324,325,327,333,335,339$, $346,347,348,353,356,359,360,363$, 364 .

Granger, General, 129.

Grant, Gen. U. S., I 30, 204, 292, 348.

Gray, Captain, I54, 156.

Greene County, 64, 66, 119, 124, 1 30, 291.

Greenlaw, W. R., I 40.

Gregg, Lafayette, 301.

Griffith, E. R., i i 4, i I 5 .

Gubernatorial office, $269,270$.

Habeas corpus, $76,85,87,105$, I 8 I.

Hadley, Hon. O. A., I 44, $270,332,333$.

Hanks, Hon. James M., 234, 235.

Haynes, Capt. A. J., I 27,135, I 37,175 , 176,177, I 78, I 79, I 80, I 81, I 82 .

Haynes, Lieut. Thomas, 1 I 8 .

Hazeldine, Captain, Iог.

Helena, Ark., 17, 18, 18, 91, 92, 94, 95, $96,126,128,130,137,176,234$.

Helena Clarion, $183,217$.

Helena Monitor, 93, 183, 201.

Hempstead County, 6o, 66, I I I, 320.

Henderson, E. E., 300.

Hervey, T. C., 187,188 .

Hicks, Aaron, 69, 79, 80 . 
Highlands, 21, 22, 23.

Hindman, Gen. T. C., 91, 92, 93, 94, $95,96$.

Hinds, Hon. James M., 70, 96, 97, 98, 99.

Hitchcock, Senator, 331, 332.

Hobbs, W. T., 187,188 .

Hodges, James L., 329, 337.

Hodges and Weeks, I06, 107.

Holford bonds, 258, 259, 260, 278, 289, 358.

Holland, Jolin G., $76,80,82$.

Hooper, Thomas, I53, I54, I9I.

Hot Spring County, 66, 320 .

Hot Springs, Ark., 289.

Howard, Robert A., I95, 320.

Howard, William, 156 , 157 .

Humphries, Ban, 62, 7o, 81, 88, 89.

Hunter, Judge, 140.

Huntsville, Ark., 263.

Illinois, I06, 282, 300, 303 .

Immigrants, 43, 200, 207, 209, $21_{4}, 2 x_{5}$, $216,217,218,219$.

Immigration, 41, 42, 43, 200, 207, 208, $209,210,211,213,215,216,217$, $218,219$.

Bureau of, $42,210$.

Chinese inmmigration, 208, $212,213$.

Commissioner of, $42,198,2$ I0, 299.

Impeachment, 261, 262, 270, 319, 321, $322,323,324,325,326,327,328$.

Impeachment, Articles of, 241, 262, 321 , $322,325,326$.

Inaugural ceremony, $x_{4}, 15$.

Incendiary fires, I $51,154$.

Indebtedness, state bonded, 44, 251, 257, $270,272,273,274,275,278,279,281$, 365 .

Independence County, 22, 23, 58, 66, 77 , $217,320$.

Indian Bay, Ark., 96, 97, 99.

Indian Territory, I 5, 143.

Indiana, 302,303 .

Indictments, 335, 339, 343 .

Inman, W. A., 302 .

Institute for the Blind, Ark., 48, 198.

Investigating Conmittee, Senatorial, 332, 338

Appointment of, 337 .

Majority report of, 337, 338, 339, 340.

Resolution of, 340,342 .

Adoption of majority report and resolution, 342 .

Minority report of, 340,342 .

Investigation, senatorial, $329,331,336$, $337,338,343,346,349$.

Iowa, I $36,300,301$.

Ixard County, 66.

Jackson County, 66, 77, 122, 123, 124, I 25.

Jackson, Capt. James A., $117,118$.

Jacksonport, Ark., I 22, I 23, 124.

Jefferson County, 20, 67.

Tolinson, Dr. A. M., 73, 74 .

Johnson County, 66, 200.

Johnson, Lieut.-Gov. James M., 28, 26I,
$262,263,264,265,269,299,315,316$, $319,327,331,332$.

Johnson, President, 30, 106, 145.

Jones, Lieut. B. Y., 123.

Jurors, 54, I62.

Kentucky, 303 .

Knights of the White Camelia, 64, 141 .

Ku Klux, 56, 59, 62, 63, 69, 70, 71, 81, 88,99, I $02,104,105$, I $08,109,113$, $116,117,122,123,124,127,135,137$, $139,149,150,151,152,153,154,163$, $178,185,196,204,205,308,309,349$.

Ku Klux Democracy, 198, 308.

Ku Klux den, 58, 60, 63, 78, 220, 365.

$\mathrm{Ku}$ Klux Klan, $34,56,58,59,60,6 \mathrm{I}$, $64,73,77,84,85,87,93,109,112$, $115,116,117,124,140,142,143,166$, 183 .

Ku Klux organization, $57,58,59,68$, $80,87,99,104,105,111,125,137$, 173.

Lafayette County, 63, 66, 69, II4, I64, 305.

Lawrence County, 66, 122.

Legislature, Arkansas, 15, 28, 29, 31, $32,34,38,46,48,54,56,67,72,98$, 1 $06,107,116,144,163,202,209,210$, $223,226,227,233,237,244,250,251$, $252,253,255,256,257,258,260,262$, $266,270,271,279,283,285,290,291$, $302,303,304,316,317,318,319,320$, $326,329,330,331,335,339,348,35 \mathrm{l}$, $352,353,354,357,358,359,360,36 \mathrm{t}$, 363 .

Levee bonds, $293,296,358$.

Lewis, Dr. J. M., 1 06, I 98, 244, 247, 299. Lewis, John P., 78, 79, 80.

Lewisburg, Ark., 18, 144, 145, 150,151 , $152,154,155,156,157,158,159,160$, $161,162,163$.

Liberal Republican National Convention, 344,345 .

Liberal Republican Party, $344,346$.

Liberal Republican State Convention, 344 .

Lieutenant-Governor, 28, 261, 262, 267, 319,332

Lincoln, President, 21, 24, 26, 27, 170.

Little River County, 63, 66, 69, 101.

Little Rock. Ark., 13, I 7, 18, 19, 20, 36, $53,57,58,60,62,65,66,75,76,81$, $84,85,92,93,98,100.107 .108,113$, I I 5,116, I 19, I 24,128, I $38,139,149$, $150,184,190,195,197,198,199,235$, $239,241,246,248,249,258,261,263$, $264,265,266,273,282,285,290,299$, $301,344,356,366$.

Little Rock Democrat, 272, 273, 276.

Little Rock and Fort Smith Railroad, $238,240,259,260$.

Little Rock and Helena Railroad, 238.

Little Rock, Mississippi River and Texas Railroad, 239, 247, 295.

Little Rock and Napoleon Railroad, 239.

Little Rock. Pine Bluff and New Orleans Railroad, $238,239,242,243,244$, $245,246,247,248,249,293,294,296$. 
Louisiana, 64, I I 5, I 3 I, 2 I I, 257, 303.

Lowlands, $21,22,23$.

Loyal League, $82,89,91,98$.

Loyal People, I9, 64, 71, 267, 284.

Loyal State Government, I9, 26, 313.

Madison, Ark., I26, I27.

Madison County, 66, 262, 263, 264, 299.

Main, Col. E. M., 89, I 27, I 29, I34, 176.

Maine, 302.

Mallory, Col. S. W., 66, 67, i I 6, I I 8 , I44, 245, 246, 29I, 321 .

Marion, Ark., I 27, I28, 1 30, I 33, I 34, 1 35, I 38, I 39, I 77, I 79, I 80, I 8 I, I 85.

Marion County, 66.

Markliam, R. T., I 45, I 50, I 52, I 56, I 57 , I 58 .

Martial law, $63,65,66,67,72,82,87$, I 5, I 6 , I 88 , I I 0 , I I I, I I 3 , I I 5 , I I 6 , I I 8, I 19, I $24,125,127$, I 29, I 32, I 33 , I $35,140,144, I_{53}, I_{54}, I_{3}, 164,165$, I 66, I 75, 1 86, 195, 196, 197, 202, 203, $204,205,268,290,291,292$.

Maryland, 53, 301.

Mason, Capt. Simpson, 5I, 70, 90, 9 I.

Massachusetts, 299, 303.

Matthews, Captain, 152, I 53, I 54, I 56.

McCauly, John, 74, 76, 77, 84, 85.

McClung, John, I 78, I79, I80.

McClure, F. A., 51, 70, 122 .

McClure, John, 244, 245, 246, 301, 337.

McConnell, W. H., 340, 34I, 342.

McGanock, Dr., I 29.

McRae, Gen. Dandridge, 76, 77, 79, 82, $83,86,87,349$.

Meeks, Joseph A., 324.

Memplis Appeal, 53, 91, 128, 179, I8I, 182, I 83 .

Memplis Avalanche, 92, I 28 .

Memplis Ledger, I8I.

Memphis and Little Rock Railroad, I27, 238, 240, 250, 292, 294, 320, 356.

Memphis Post, 139, 177.

Memphis, Tenn., 29, 32, 33, 58, 59, 76, 83,90, I $07,127,129,130,137$, I 38 , I $39,142,143,177,178,179,182,183$, 213,216

Mexico, $95,250,366$.

Michigan, $46,224,303$.

Military conmission, 87, I I3, II4, I I7, I $18,128,138,139,153$.

Military districts, 66, I I9, 137.

Militia law, г o6, I 48 .

Militia, state, $28,40,41,63,66,67$,

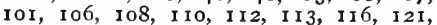
I 26,128, I $30,132,133,139$, I 40 , I 44 , I 48,153 , I $55, I_{56,}$ I 57 , I 58 , I 59, I 60 , $165,178,179,183,191,202,215,291$, 365,367 .

Militia operations, 61, 1 16, г21, 126, 291.

Miller, Mr. Justice, 203.

Miller, William R., 256.

Mills, C. B., 270, 272, 273, 276, 278, $279,280$.

Milis, Isaac, 343 .

Minor, Charles, 324.

Mississippi, 140, 268 .
Mississippi County, 63, 66, 128, 129, I $30,133$.

Mississippi River, 29, I68, I77, I78, 239, 240, 247, 294, 296, 3 Io.

Mississippi, Ouachita and Red River Railroad, 238, 239, 242, 247, 248, 249, $293,294,296,320,326,332,357$.

Missouri, I8, 74, I 29, 303, 3 I 5 .

Monks, Lieut.-Col. William, I 22, 127 , I 28, I 29, I 34 .

Monroe County, 66, 70, 96, 97, 99.

Montgomery County, 66, 216, 320.

Montgomery, Atty.-Gen. John R., 299.

Monticello, Ark., 6o, I I6, I I7, I I8, 204, 205.

Morgan, Stokeley, I I 7, I 8 .

Morrill, Senator, 337.

Morriliton, Ark., 187

Mound City, Ark., I77, I8I.

Mower, Gen. J. A., 202.

Murfreesboro, Ark., III, II2.

Murphy Government, I 7, 26, 28, 29, 30, $31,110,172,223,283,284$.

Murphy, Gov. Isaac, 14, 15, 16, 25, 28, $31,34,282$.

Mysterious stranger, 57, 58, 61, 62, 149.

Nashville, Tenn., 29, 1 I 2.

Ncal, C. B., 324.

Nebraska, $33 \mathrm{I}$.

Negro domination, I I6, 307, 308, 309, 3 IO.

Negro population, $98,307,308,310$.

Negroes, I 4, 27, 53, 61, 70, 73, 88, 89, $93,94,98,102,105,147,149,150$, I 5 I, I 54, I 63, I 68, I 80, I 97, 205, 208, $214,288,308,309,3$ I0.

Neill, Bvt.-Brig.-Gen. Thomas H., I3 I.

New Hampshire, 303.

New Memphis Theater, I 39, I 4 I.

New Mexico, 277.

New Orleans, 33, I31, 248, 296.

Newton County, 66 .

New York, 242, 244, 248, 258, 261, 262, $263,266,271_{2} 273,275,277,278,279$, $280,303,326$.

Night riders, 56, I05, I35, 308.

North Carolina, 303.

Norwood, Senator, $337,340$.

October speech, 312, 315, 316, 317.

Ohio, 301, 303.

Oklahoma, I 43,144

Oliver, Col. W. S., 144.

Ord, Bvt.-Maj.-Gen. E. O. C., 34.

Order of the White Man, 59.

Orr, Thomas, II 4 .

Osceola, Ark., 74.

Ouachita County, 66.

Padgett, W. B., 319, 320.

Page, Col. Henry, 270, 27 I, 272, 274, $275,278,299,364,365$.

Page, Hon. J. R., 302.

Palmer, William, I87, i 88.

Parker, Albert H., 62, 63, 74, 75, 76, $80,81,82,84,86,87,349$.

Parker, David B., 62.

Patterson, W. K., 125. 
Peabody Educational Fund, 229.

Peak, Thomas C., 259, 260, 261.

Pennsylvania, 303, 340, $34 \mathrm{I}$.

Permanent school fund, 353, 354, 355, $361,364$.

Perry County, 66, 160.

Philadelphia, Pa., 342, 345.

Phillips County, I9, 66, 126, 310.

Picket, Col. A. C., 123, 124, 125.

Pike, Gen. Albert, 53.

Pike County, 66.

Pine Bluff, Ark., 17, 18, 31, 56, 116, $215,235,247,249,294,295,296,302$.

Plummerville, Ark., 150, 186, 187, 189, 190.

Poinsett County, 66 .

Poland Committee, 348 .

Polk County, 66, 320 .

Poor's Manual of Railroads, 240.

Pope County, 66, II , 150.

Porter, Charles, 92, 93.

Porter, Gen. Horace, i $30,204,292$.

Prairie County, 66, 84, 215.

Presidential campaign, I43, 286, 309 .

Prigmore, Capt. George, i 6 , I i 8 .

Provisional government, 24, 26, 28, 29, 35.

Provisional legislature, I7, 34, 35.

Pulaski County, 20, 66, 75, 98, 307, 320, $329,343$.

Radical Party, 54, 85, 89, 90, 92, 97, $98,99,287,288$.

Radical press, 90, 269 .

Radical rule, $266,267$.

Radicalism, 92, 265, 267.

Radicals, 52, 81, 88, 89, 92, 95, 97, 98, 268,287 .

Railroad aid bonds, 238, 239, 242, 243, $244,245,246,250,289,293,294$, $295,320,326,332,356,357,358$.

Railroad Bill, 42, 237, 239, 240, 243 , $246,247,292,357$.

Railroad companies, 237, 238, 239, 243, $247,248,250,266,292,295,296,356$, 357.

Railroads, 40, 43, 44, 197, 199, 239, 240, $241,242,247,249,259,266,294,297$ 326,332 .

Randolph County, 15, 66.

Rankin County, $156,158,159$.

Real Estate Bank, 16, 251, 252, 253, $254,255,256,257,258,274,275$.

Rebellion, 26, 29, 38, 50, 65, 147, 149, 161, $171,312,316$.

Rebels, 27, 36, 70, 89, 108, 1 22, 140, I41, I77, 291, 292.

Reconstruction, $29,95,96,172,203$, $273,275,285,286,292,366,368$.

Reconstruction measures of Congress, I $4,17,29,32,34,35,37,50,166,265$, $300,302,306$.

Rector, Gov. Henry M., 46, 221, 222, $223,224$.

Reed. Charles C., 187.

Reeves, Captain, II2.

Reeves, "Fed," I 17.

Registered voters, $46,50,224,346$.

Registrars, 50, 51, 69, $35 \mathrm{r}$.
Registration, 41, 50, 51, 64, 69, 70, 90, $91,147,148,269,316,330,351,352$.

Remmel, Hon. H. L., 307.

Republican administration, $252,314,360$.

Republican counties, 304, 305.

Republican, The Daily, $56,86,99,124$ $144,151,155,161,208,215,241$, $259,260,263,302,367$.

Republican National Committee, 307, $345,346$.

Republican National Convention, 345.

Republican Party, 35, 142, 204, 21 I, $233,262,268,270,286,287,292,313$, $315,331,343,345,346,347$.

Republican press, $197,269$.

Republican rule, $240,298,353$.

Republican State Convention, 285 .

Republicans, 31, 61, 88, 93, 94, 95, 96, $102,127,140,152,184,208,217,262$, $265,268,270,281,284,310,312,315$, $318,328,347,348,349,351,352,353$, $356,364,365$.

Repudiation, $285,359,365$.

Reynolds, Prof. John H., I $9,22$.

Reynolds, Gen. J. J., ro9, 172.

Rice, B. F., 98, 301, 343, 344, 345, 349.

Richmond, Ark., I01, 102, 367 .

Roane, Captain, I54, I56, I59.

Roane, Governor, 253.

Robertson, Capt, A. W., 123.

Rocky Comfort, Ark., Ioo, Ior, 114.

Roosevelt, President, 366.

Rousseau, Colonel, r 30.

Royston, Grandison D., 16.

Russell, D. B., 160.

Russell, James W., 80, 82, 83, 88

Ryan, Col. A. H., 247, 248.

Ryan, Col. James, 144.

Saline County, I6, 23, 66.

Schaurte, Colonel, 122.

Scliofield, Gen. John M., 108.

Schoolhouses, 198, 199, 220, 228, 229 230.

School law, 230, 23 I.

School system, 46, 47, 48, 221, 226, 229 , $230,231$.

School teachers, $46,47,224,226,227$, $228,230,231,232$.

Schools, 47, 225, 226, 227, 229, 230, 232.

Schools, common, 45, 46, 221, 222, 223, 224, 229, 254 .

Schools, free, 22, 45, 46, 221, 222, 223 , $224,229,230,231,266,353$.

Schools, public, 222, 229, 300, 355 .

Scott, C. G., 240.

Scott County, 66, 320.

Scott, Senator, $334,336,342$.

Searcy, Ark., 74, 77, 79, 81, 88, 89.

Searcy County, 66 .

Searcy Ku Klux den, 75, 76, 82, 83 .

Searchy White County Record, 76, 77, 86.

Searle, Judge, 99, roo.

Sebastian County, $18,66,282,285$.

Secession, 28, 31, 62, I69, 1 70, 172, 282 .

Secessionists, i $7,169,282$.

Secret agents, 61. 62, 63 . 
Secretary of Interior, U. S., 234, 235. Secretary of State, Ark., 28, 65, 22 I, $222,243,266,267,298,299,304,326$, $329,330,331$.

Secretary of War, U. S., 108, 202.

Senatorial election, 314, 315, 316, 328, $331,333,339$.

Senter, Governor, 270, 315, 332.

Sevier County, 63, 66, 69, 111 .

Sewell, William, 78, 79, 80, 84 .

Sharp County, 66, 122 .

Shaver, Gen.' R.' G., 59, 60, 61, 123, 124.

Sickels, Jackson E., 244, 247, 248, 332.

Simms, Thomas H., 363, 364 .

Slave-holders, 22, 102, I67, 168, I69, $220,222,347$.

Slave-holding régime, 30, 217.

Slavery, 28, 38, I69, I 70, 17 1, 172 .

Slayton, John W., I $24,125$.

Smith, Gen. C. H., 204, 290, 291, 292.

Smith. D. J., 320 .

Smith, Gen. E. Kirby, I08.

Smith, Gen. James F., 60.

Smith, Dr. Thomas, 95, 227, 229, 230, $231,299$.

Southall, Dr. J. H., 136.

South Carolina, 303.

Standal, Mr., Sheriff of Little River County, I00, 101, 102.

State aid, 44, 237, 238, 239, 240, 241, $242,246,297$.

State Aid Bill, 42, 237, 239, 240, 243, $246,247,292,356$.

State aid bonds, 238, 239, 242, 243, 244, $245,246,250,293,294,295,320,326$, $332,356,357,358$.

State aid to railroads, 237, 250, 251 , $266,332,356$.

State authorities, $91,104,146$.

State Bank of Arkansas, 234, 251, 256, $257,258,274,275$.

State bonds, 246, 251, 252, 254, 256, $257,258,259,266,267,270,271,272$, $273,274,275,277,278,279,280,289$, $292,293$.

State canvass, $36,37,74$.

State Central Committee, 52, 307, 344, 349.

State convention, $310,344,346$.

State's credit, 40, 44, 237, 241, 242, $25 \mathrm{I}, 255,256,259,359$.

State government, 1 $3,24,25,26,35,40$, $44,62,63,64,65,68,78,110,113$, $132,146,149,165,166,173,195,196$, $205,212,218,219,235,261,265,266$, $268,269,290,298,303,306,313,316$, $349,353$.

State guards, $63,65,66,67,70,91,117$, I $56,290$.

State House, I3, I4, 15, 49, 184, 301, 352.

State officers, $28,61,86,113,298,353$, 355.

State scrip, 231, 232, 353, 362, 363.

State troops, I21, I34, 135, 137, 176.

Steele, Major-General, 24, 25, 26, 27, 29.

Stephenson, Judge, 95.
Steven, Dr. H. K., 2 I 7 .

St. Francis County, 66, 126, 127, 129.

St. Francis River, $127,240$.

St. Louis, Mo., 94.

Sumner, Senator Charles, 26.

Superintendent of Public Instruction, $47,95,221,227,299,355$.

Supreme Court, Arkansas, 244, 245, 246, $319,329,330,335,339,348$.

Temple, N. J., 302.

Tennessee, 29, 59, $213,216,217,257$, 268, 270, 303, 309, 315, 332.

Texas, 62, 64, 76, 81, 109, I15, 211,214 , 268.

Thayer, Gen. J. M., 25.

Thomas, Dr. A. D., 150.

Thompson, F. M., 320 .

Thompson, Woodville E., $221,223,230$.

Thorn, Attorney-General, 140.

Tourtelotte, Col. J. E., Ioo.

Townsend, Jake, 99, 100.

Texas vs. White, 35, 166.

Unconditional Union, The, 19, 283, 284 .

Union, 24, 26, 38, 68, 172, $217,221,234$, $25 \mathrm{I}, 282,283,360$.

Union Army, I 8, 22, I 36, 299.

Union County, 66, $20 \mathrm{r}$.

Unionists, I9, 282 .

Union men, I8, 24, 35, 69, 70, 72, 75, I 1 $0,176,283,284$.

Union soldiers, I3, I 10, I67.

Union Trust Company of New York, $271,272,278,279,280,364$.

United States, 50, 65, 81, 107, 1 28, I 70, $171,173,188,189,217,234,238,250$, $256,274,335,354$.

United States Army, 100, 204, 290, 292, 298.

United States Census, 220, 222, 229, 307.

United States Court, I88, I89, 331, 356.

United States Senate, 18, 26, 29, 98, $170,234,235,283,284,315,328,329$, $331,333,335,336,337,343,345$.

United States Supreme Court, 35, I66, 203.

United States troops, 129, 131, 202, 292, 348.

Upham, Gen. D. P., 51, 66, 70, I 19, 1 20, I $21,122,124,125,127,128$, I 30,134 , I 38, I 39, 144, 290.

Utah, 277.

Van Buren, Ark., 18, 19, 66, 100, 300.

Van Buren County, 305.

Vance, Judge, I40.

Vermont, 303.

Virginia, r $36,268,270,282,299,303$, $315,332$.

Wahl, Charles, 188, 189, 190.

Waldron, Judge, 140 .

Walker, Governor, 270, 31 5, 332.

Walker, Maj. Samuel, 62 .

Warwick, Judge, 84 .

Washington, D. C., 29, 32, 154, I91, $256,284,333,346,348,366$. 
Washington County, 22, 23, 66.

Washington, George, 15.

Watson, E. L., I 25 .

Watson, Col. J. T., I 26, I 30, I 33, I 34, I $37,176$.

Wells, A. C., 156, I 60 .

Wheeler, Edward, 333, 334.

Wheeler, State Senator Stephen, 62, 70, $79,80,84$.

Whipple, Col. W. G., 333, 334, 343.

White County, $58,62,66,70,74,75$, $76,77,81,82,83,84,85,86,87$, 349.

White River, 66,67, I I9, I $30,216$.

White, Hon. Robert J. T., 28, 65, 299, 33 I, 332, 333 .

Whytock, Judge John, 87, 348.

Williams, Captain, I 54 .
Williams, Col. Willoughby, 29, 30, 31 , 35.

Willis, Lieut. H. F., 69, 99, 100, Iо1, I 02 , I I 4.

Wilshire, Judge W. W., 300, 313.

Wilson, C. N., I 75 , I 77.

Wilson, John, I5, I6, 252.

Woodruff County, 51, 62, 66, 70, II9, I $21,123,124,125,208,209,217,29 I$.

Woodruff, W. E., 364 .

Wright, Senator, $336,337,338,340,342$.

Yahoos, 83, 87.

Yankee, I 35, I70, 303, 308, 359.

Yell County, 66, 216.

Yell, Governor, 252 .

Yonley, Judge T. D. W., 36, 37, 283, 301 . 




